Editörden

Okul-Gercek Yasam ve Sorumluluk Üstlenme Illişkisini Sorgulayan Yeni Bir Drama Yaklaşımı: Komisyon Modeli

Zeki Özen, Ömer Adıgüzel $\ldots . .153$

Leonardo Da Vinci’nin “Son Akşam Yemeğğ” Adlı Eserinin Yaratııı Drama Yöntemiyle Ç̈zzïmlenmesinde Oğrenci Görüşlerinin Belirlenmesi

Abdulgafar Terzi, Nami Eren Beștepe

Yaratıc Drama Eğitmenlerinin Sosyal Adalet Tutumlarımin İncelenmesi

Serkan Keleşoğlu, İhsan Metinnam

Illkokula Devam Eden Kaynaştırma Öğrencilerinin Smıf Ị̇i Etkinliklere Katılım Düzeyine Yaratıı Drama Yönteminin Etkisinin Iñcelenmesi

Fatih Kıvanç Erdoğan, Süleyman Arslantaş,

Ahmet Kurnaz

İnsan Iliskkileri ve Iletisisim Dersinde Yarattcı Drama

Uygulamalarının Etkisine İlişkin Öğrenci Görüşleri

Mustafa Yeler.

Okul Öncesi Dönemde Yaratıcı Drama Yoluyla Değerler Ĕ̈itimi

Yildiz Kaya, Serap Antepli

Sosval Hizmet E.ğitiminde Yaratıcı Dramanın Önemi

Ecem Naz Nazler, Gizem Akoğlu $\ldots . .251$

Yaratııı Drama Dergisine Illişkin Açıllamalar ve Yazım Kuralları

73
Editorial

A New Drama Approach Questioning the Relationship Cencer Scholpellife Commission Model

Zeki Özen, Ömer Adıgüzel

$\ldots . .153$

Determining of Students' Views Regarding the Analysis of "Last Supper" by Leonardo Da Vinci Through Creative Drama

Abdulgafar Terzi, Nami Eren Beștepe

.173

Investigation of Social Justice Attitudes of Creative Drama Trainers

Serkan Keleşoğlu, İhsan Metinnam .189

The Analysis of the Effect of Creative Drama Activities on Participation Levels of Elementary School Inclusive Students Diagnosed with a Learning Disability in Classroom Activities

Fatih Kıvanç Er

Students' Views on the Effects of Creative Drama in Human Relationships and Communication Course

Mustafa Yeler...

$\ldots . .214$

The Values Education in Preschool Period Through

Creative Drama

Yldiz Kaya, Serap Antepli

The Importance of Creative Drama in Social Work Education

Ecem Naz Nazler, Gizem Akoğl

$\ldots . .251$

Submission Guidelines for Creative

Drama Journal.

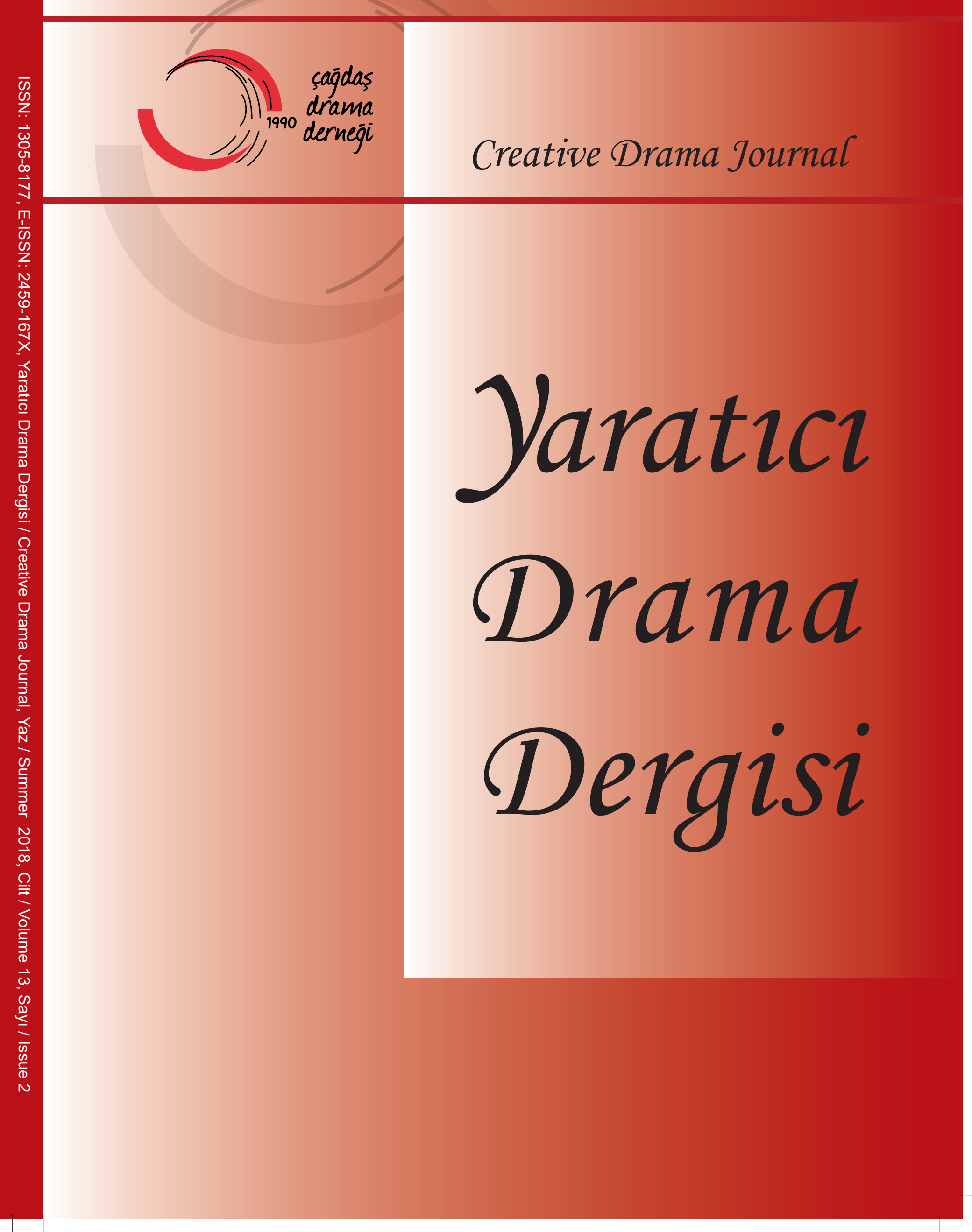




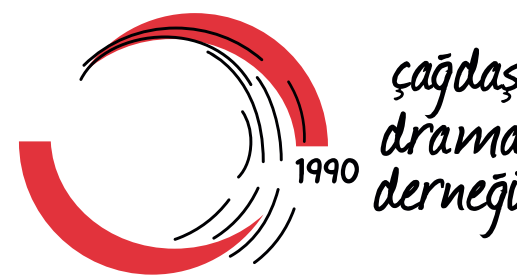

\section{Creative Drama Journal}
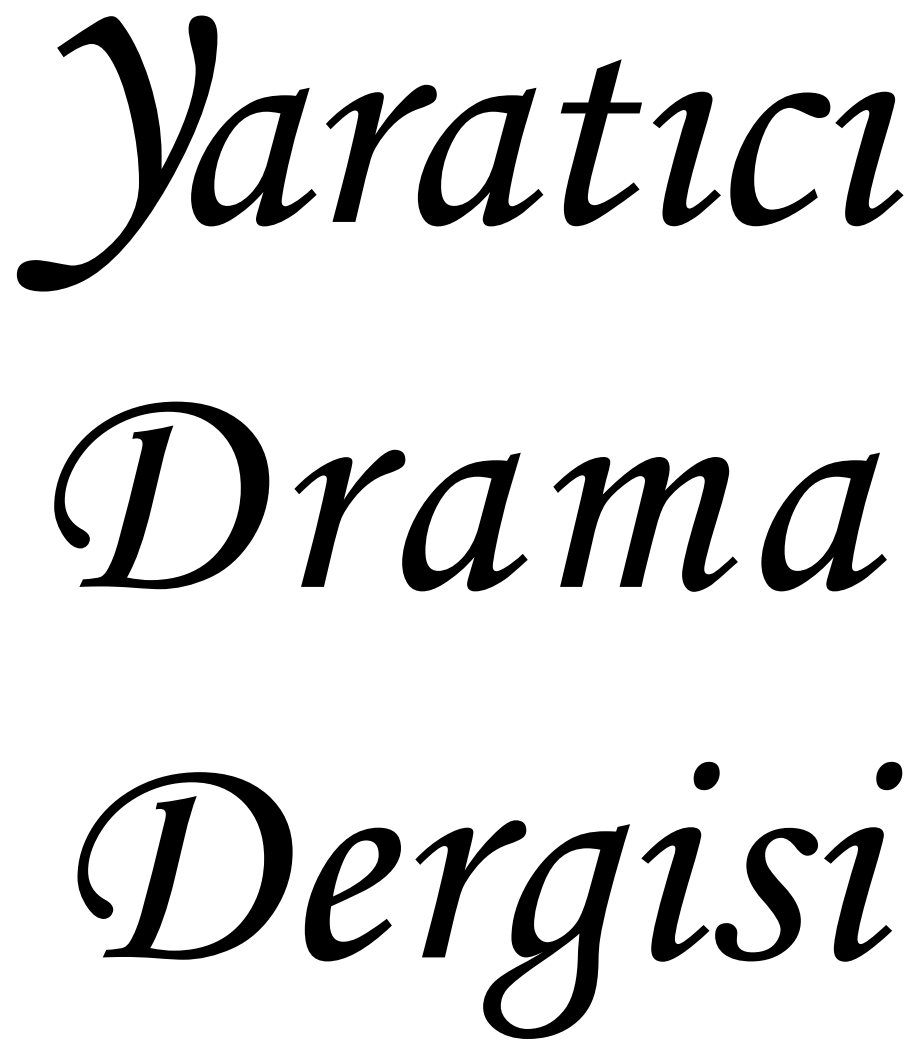
Yaşare Aktaș Arnas (Prof. Dr., Çukurova Üniversitesi) David Davis (Prof. Dr., Birmingham City Üniversitesi) Mübeccel Gönen (Prof. Dr., Hacettepe Üniversitesi) Sibel Güneysu (Prof. Dr., Başkent Üniversitesi) Ayşe Çakır İlhan (Prof. Dr., Ankara Üniversitesi) Gerd Koch (Prof. Dr., Berlin Alice Salomon Yüksek Okulu) Nihal Kuyumcu (Doç. Dr., İstanbul Üniversitesi)
Tamer Levent (Ankara Devlet Tiyatroları, TOBAV Gen .Bşk.)

H. Wolfgang Nickel (Prof. Dr., Berlin GSÜ. Emekli. Öğr. Üy.)

Esra Ömeroğlu (Prof. Dr., Gazi Üniversitesi)

İnci San (Prof. Dr., Ankara Üniversitesi, Emekli Öğr. Üy.)

John Somers ( Exeter Üniversitesi Emekli Öğr. Üy.)

*Soyadına göre alfabetik sırada/In alphabetical order
Ömer Adıgüzel ( Prof. Dr., Ankara Üniversitesi) Ferah Burgul Adıgüzel (Dr., Gazi Üniversitesi)

Fatma Önalan Akfirat (Dr.,Öğr. Üy., Uluslararası Kıbrıs Üni.)

O. Nejat Akfirat (Dr.,Öğr. Üy., Kocaeli Üni.)

Berrin Akman (Prof.Dr. Hacettepe Üniversitesi)

Hasan Akbulut (Prof. Dr., İstanbul Üniversitesi)

Yaşare Aktaş Arnas (Prof. Dr., Çukurova Üniversitesi)

İsmihan Artan (Prof. Dr., Hacettepe Üniversitesi)

Necdet Aykaç (Doç. Dr., Muğla Üniversitesi)

Murtaza Aykaç (Dr.,Öğr. Üy., Niğde Üniversitesi)

Tuncer Bülbül (Doç. Dr., Trakya Üniversitesi)

Pınar San Bayhan (Prof. Dr., Hacettepe Üniversitesi)

Neval Akça Berk (Dr.,Öğr. Üy., Çukurova Üniversitesi)

Nami Eren Beştepe (Dr.,Öğr. Üy., Mustafa Kemal Üni.)

Selen Korad Birkiye (Doç. Dr., İstanbul Devlet Tiyatroları)

Ahmet Çebi (Dr.,Öğr. Üy., On Dokuz Mayıs Üni.)

Figen Çok (Prof. Dr., Başkent Üniversitesi)

David Davis (Prof. Dr., Birmingham City Üniversitesi)

Kenan Demir (Dr.,Öğr. Üy., Mehmet Akif Ersoy Üniversitesi)

Çağlayan Dinçer Atila (Prof. Dr., Ankara Üniversitesi)

Celal Deha Doğan (Dr.,Öğr. Üy., Ankara Üniversitesi)

Dagmar Dörger (Prof. Dr. Erfurt Üniversitesi)

Tolga Erdoğan (Doç. Dr. Karadeniz Tek.Üni.)

Selda Ergün (Dr.,Öğr. Üy., Dokuz Eylül Üniversitesi)

Stig A. Eriksson (Prof. Dr., Bergen Üniversitesi)

Özlem Ersoy (Doç. Dr., Gazi Üniversitesi)

Selahattin Gelbal (Prof. Dr., Hacettepe Üniversitesi)

Mübeccel Gönen (Prof. Dr., Hacettepe Üniversitesi)

Rezzan Gündoğdu (Doç. Dr., Aksaray Üniversitesi)

Sibel Güneysu (Prof. Dr., Başkent Üniversitesi)

İsmail Güven (Prof. Dr., Ankara Üniversitesi)

Ulrike Hentschel (Prof. Dr., Berlin Güzel Sanatlar Üni.)

Ayşe Çakır İlhan (Prof. Dr., Ankara Üniversitesi)

\section{BU SAYININ HAKEMLERİ / JUDGES OF THIS ISSUE}

Ömer Adıgüzel (Prof. Dr., Ankara Üniversitesi)

Fatma Önalan Akfirat (Dr.Öğr.Üy., Uluslararası Kıbrıs Üni.)

Yaşare Aktaş Arnas (Prof. Dr., Çukurova Üniversitesi)

Murtaza Aykaç (Dr.Öğr. Üy., Niğde Üniversitesi)

Nami Eren Beştepe (Dr.Öğr.Üy., Mustafa Kemal Üni.)

İnanç Eti (Dr., Çukurova Üniversitesi)

Rezzan Gündoğdu (Doç. Dr., Aksaray Üniversitesi)
Elif İskender (Dr.,Öğr. Üy., Dokuz Eylül Üniversitesi)

Oylum Akkuş İspir (Doç. Dr. Ohlone Üniversitesi)

Özlem Kaf (Dr.,Öğr. Üy., Çukurova Üniversitesi)

Ceren Karadeniz (Dr. Ankara Üniversitesi)

Serkan Keleşoğlu (Dr., Ankara Üniversitesi)

Gerd Koch (Prof. Dr., Berlin Alice-SalomonYüksek Okulu)

Müfit Kömleksiz (Prof. Dr., Lefke Avrupa Üniversitesi)

Ferda Öztürk Kömleksiz (Dr.,Öğr. Üy., Lefke Avrupa Üni.)

Ömer Kutlu (Dr.,Öğr. Üy., Ankara Üniversitesi)

Nihal Kuyumcu (Doç. Dr. İstanbul Üniversitesi)

Hadiye Küçükkaragöz (Dr.,Öğr. Üy., Dokuz Eylül Üni.)

Laura A. McCammon (Prof. Dr., Arizona Üniversitesi)

İhsan Metinnam (Dr., Trakya Üniversitesi)

Ömer Nayci (Dr.,Öğr. Üy., Şırnak Üniversitesi)

H. Wolfgang Nickel (Prof. Dr., Berlin GSÜ Ü.Em.Öğ.Üy.)

Helen Nickholson (Dr., Royal Holloway Üniversitesi)

Mehmet Öcal Özbilgin (Prof. Dr., Ege Üniversitesi)

Ayşe Okvuran (Doç. Dr., Ankara Üniversitesi)

Anna-Lena Ostern (Prof. Dr., Bergen Üniversitesi)

John O'Toole (Prof. Dr., University of Melbourne)

Esra Ömeroğlu (Prof. Dr., Gazi Üniversitesi)

Alev Önder (Prof. Dr., Marmara Üniversitesi)

Pınar Özdemir Şimşek (Doç.Dr., Hacettepe Üniversitesi)

Ali Öztürk (Doç. Dr., Anadolu Üniversitesi)

Asuman Duatepe Paksu (Dr.,Öğr. Üy., Pamukkale Üni.)

İnci San (Prof. Dr., Ankara Üniversitesi, Emekli Öğr. Üy.)

John Somers (Exeter Üniversitesi)

Ülker Şen (Doç.Dr., Gazi Üniversitesi)

Özlem Ünal (Dr., Hacettepe Üniversitesi)

Tülay Üstündağ (Dr., Hacettepe Üniversitesi Emekli Öğr.Elm.)

Florian Vaßen (Prof. Dr., Hannover Ün. Emekli Öğr.Üy.)

İncilay Yurdakul (Prof. Dr., Hacettepe Üniversitesi)

* Soyadina göre alfabetik sirada/In alphabetical order

Serkan Keleşoğlu (Dr., Ankara Üniversitesi)

Hare Kılıçaslan (Dr., Çağdaş Drama Derneği)

İhsan Metinnam (Dr., Ankara Üniversitesi)

Ömer Nayci (Dr., Öğr.Üy., Şırnak Üniversitesi)

Zeki Özen (Dr., Ankara Üniversitesi)

Ali Öztürk (Doç. Dr., Anadolu Üniversitesi)

* Soyadına göre alfabetik sırada/In alphabetical order 
Editörden

iv

Okul-Gerçek Yaşam ve Sorumluluk Üstlenme İlişkisini Sorgulayan Yeni Bir Drama Yaklaşımı: Komisyon Modeli

Zeki Özen, Ömer Adıüzel

Leonardo Da Vinci’nin “Son Akşam Yemeği” Adlı Eserinin Yaratıcı Drama Yöntemiyle Çözümlenmesinde Öğrenci Görüşlerinin Belirlenmesi

Abdulgafar Terzi, Nami Eren Beştepe

Yaratıcı Drama Eğitmenlerinin Sosyal Adalet

Tutumlarının İncelenmesi

Serkan Keleşoğlu, İhsan Metinnam. 189

İlkokula Devam Eden Kaynaştırma Öğrencilerinin Sınıf İçi Etkinliklere Katılım Düzeyine Yaratıcı Drama Yönteminin Etkisinin İncelenmesi

Fatih Kıvanç Erdoğan, Süleyman Arslantaş,

Ahmet Kurnaz.

İnsan İlişkileri ve İletişim Dersinde Yaratıcı Drama Uygulamalarının Etkisine İlişkin Öğrenci Görüşleri

Mustafa Yeler.

Okul Öncesi Dönemde Yaratıcı Drama Yoluyla Değerler Eğitimi

Yıldız Kaya, Serap Antepli

Sosyal Hizmet Eğitiminde Yaratıcı Dramanın Önemi

Ecem Naz Nazlıer, Gizem Akoğlu

Yaratıcı Drama Dergisine İlişkin Açıklamalar ve Yazım Kuralları
Editorial V

A New Drama Approach Questioning the Relationship Between School-Real Life and Taking Responsibility: Commission Model

Zeki Özen, Ömer Adıgüzel 153

Determining of Students' Views Regarding the Analysis of "Last Supper" by Leonardo Da Vinci Through Creative Drama

Abdulgafar Terzi, Nami Eren Beştepe

Investigation of Social Justice Attitudes of

Creative Drama Trainers

Serkan Keleşoğlu, İhsan Metinnam.

The Analysis of the Effect of Creative Drama Activities on Participation Levels of Elementary School Inclusive Students Diagnosed with a Learning Disability in Classroom Activities

Fatih Kıvanç Erdoğan, Süleyman Arslantaş,

Ahmet Kurnaz.

Students' Views on the Effects of Creative Drama in

Human Relationships and Communication Course

Mustafa Yeler.

The Values Education in Preschool Period Through

Creative Drama

Y1ld1z Kaya, Serap Antepli

The Importance of Creative Drama in Social Work Education

Ecem Naz Nazlıer, Gizem Akoğlu 251

Submission Guidelines for Creative

Drama Journal. 


\section{Editörden}

Yaratıı Drama Dergisinin 13. cilt 2. sayısını yayımlarken sizlerle güzel haberler paylaşmanın sevincini yaşıyoruz. 2006 yılından bu yana yaratıı drama alanındaki akademik çalışmaların paylaşım platformu olan Yaratıcı Drama Dergisi, TÜBİTAK ULAKBİM Sosyal ve Beşeri Bilimler Veri Tabanı Komitesi tarafindan 2017 yllından itibaren veri tabanına alınmaya uygun bulunmuştur. Bu güzel gelişme, dergimizin akademik düzeyinin ve yaygınlğının her sayıda gelişerek arttığın göstermekle birlikte bizleri de dergimizin uluslararası indekslere girmesi yolundaki çalışmalarımızı hızlandırmaya teșvik etmiştir.

Elbette bu tür güzel gelişmeler bir anda gerçekleşmez, uzun bir çalş̧ma evresinin ürünü olup "her hikâyenin bir başlangıcı vardır". Dergimizin hikâyesini başlatan ilk editörümüz Dr. Fatma Akfırat, dergimizin akademik çerçevesini çizerek uzun bir süre dergimizin editörlüğ̈̈nü yürü̈tmüş, ardından Prof. Dr. Ömer Adıgüzel süreci devralarak derginin akademik çizgisini geliştirerek sürdürmüştür. Bu sürece yardımcı editörlük görevi ile katkıda bulunan Doç. Dr. Oylum Akkuş İspir, Doç. Dr. Pınar Şimşek Özdemir, Doç. Dr. Başak Uysal da dergimizin bugünlere gelmesinde önemli pay sahipleridir. Dergimizin başarısında en büyük etkisi olan kahramanlarımız ise elbette çalışmaların dergimize gönderen yazarlarımız ve bu çalışmaları titizlikle değerlendiren hakemlerimizdir. 2006 yılından bu yana Yaratıcı Drama Dergisinin oluşumunda ve gelişiminde emeği geçen herkese; yaratıcı drama adına böyle bir akademik mirası oluşturdukları, geliştirdikleri, yaydıkları ve destekledikleri için ne kadar teşekkür etsek azdir, sizlere minnettariz.

Her geçen gün yaratıcı drama alanında yapılan çalışmaların hem nitelik hem de niceliğinin artması, farklı disiplinlerle yaratıcı dramanın buluşturulması ve bu çalışmalara dergimizde yer vermek bizleri oldukça mutlu ediyor. Bu sayımızda yaratıcı drama yaklaşımlarından komisyon model, sanat eğitiminde yaratıcı drama, yaratıcı drama ve sosyal adalet ilişkisi, yaratıcı drama ve iletiş̧im, kaynaştırma öğrencileri ve yaratıcı drama, değer eğitimi ve yaratıcı drama ile sosyal hizmet eğitimi ve yaratıc drama gibi çeşitli disiplinlerde yedi yeni çalışma ile sizlerleyiz.

Dergimizin bu sayısında; Zeki Özen ve Ömer Adıgüzelin Okul-Gerçek Yaşam ve Sorumluluk Üstlenme İlişkisini Sorgulayan Yeni Bir Drama Yaklaşımı: Komisyon Modeli, Abdulgafar Terzi ve Nami Eren Beştepénin Leonardo Da Vinci’nin "Son Akşam Yemeğgi” adlı Eserinin Yaratıcı Drama Yöntemiyle Çözümlenmesinde Öğrenci Görüşlerinin Belirlenmesi, Serkan Keleşoğlu ve İhsan Metinnamin Yaratıcı Drama Liderlerinin Sosyal Adalet Tutumlarının İncelenmesi, Fatih Kıvanç Erdoğan, Süleyman Arslantaşv ve Ahmet Kurnaz’n İlkokula Devam Eden Kaynaştırma Öğrencilerinin Sinıf İçi Etkinliklere Katılım Düzeyine Yaratıcı Drama Yönteminin Etkisinin İncelenmesi, Mustafa Yeler'in İnsan İlişkileri ve İletişim Dersinde Yaratıcı Drama Uygulamalarının Etkisine İlişsin Öğrenci Görüşleri, Yıldız Kaya ve Serap Anteplinin Okul Öncesi Dönemde Yaratıcı Drama Yoluyla Değerler Ĕ̆itimi, Ecem Naz Nazher ve Gizem Akoğlu’nun Sosyal Hizmet Eğitiminde Yaratıcı Dramanın Önemi adlı makaleleri yer almaktadır.

Dergimizin 13. cilt 2. sayısından itibaren Dr. İhsan Metinnamin yardımcı editör olarak dergimize katkı sağlamaya başladı̆̆ı duyurmak isteriz. Dergimizin bu sayısını da yaratıcı drama alanında yapılan yeni çalışmalar açısından değerlendirmenizi, alanımızın ve bireysel olarak eğitmenlik boyutumuzun farklı alanlarla etkileşimi açısından yayınlarımızı takip etmenizi diliyoruz. Bu sayımızı çalıșmalarıyla destekleyen yazarlarımıza, titizlikle değerlendirme yapan hakemlerimize ve emeği geçenlere çok teşekkür ediyor, sizlerin de çabamıza ortak olmanızı bekliyoruz.

Yaratıcı drama alanına katkı sağlamak amacıyla yapılacak yeni araştırma ve projelerin yer alacağı 2019 yılının ilk sayısında buluşmak dileğiyle...

\section{Dr. Ferah Burgul Adıg̈̈zel}

\section{Editör}




\section{Editorial}

We are so happy to share good news with you in the issue 2 of the volume 13 of the Creative Drama Journal. Having been the sharing platform for academic studies carried out in the field of creative drama since 2006, the Creative Drama Journal has been approved to be included in the database by TÜBİTAK ULAKBİLIM (Turkish Academic Network and Information Centre) Social and Human Sciences Database Committee from 2007 onward. This beautiful development has proved that the academic level and prevalence of our Journal is improving and increasing with each issue, as well as encouraging us to accelerate our efforts to gain admission into international indexes for our Journal.

Of course, such developments do not take shape out of nowhere; it is a product of long endeavours and "every story has a beginning". Our first editor, PhD. Fatma Akfirat, who started the story of our Journal, drew up its academic framework and performed as the editor for a long while, then Prof. Dr. Ömer Adigüzel took over, improved and maintained the academic framework of our Journal. Assoc. Prof. Dr. Oylum Akkuş İspir, Assoc. Prof. Dr. Pınar Şimşek Özdemir, Assoc. Prof. Dr. Başak Uysal, who contributed to this progress as assistant editors, have played a great part in coming to these days of our Journal. And of course, it was our authors, who sent their works to our Journal, and our reviewers, who meticulously evaluated these works, that played the biggest part in the success of our Journal. We can't thank those, who contributed to the creation and development of the Creative Drama Journal since 2006, enough for creating, developing, spreading and supporting such an academic legacy for the sake of creative drama, we are grateful to all of you.

It fills us with great joy to know that the quality and quantity of studies carried out in the field of creative drama is increasing day by day, to introduce different disciplines with creative drama and to include these studies in our journal. We have seven new studies from various disciplines such as commission model which is one of the creative drama approaches, creative drama in art education, the creative drama and social justice relation, creative drama and communication, inclusive students and creative drama, value education and creative drama, and social services education and creative drama.

In this new issue of our journal you will have a chance to read these articles; A New Drama Approach Questioning the Relationship Between School-Real Life and Taking Responsibility: Commission Model by Zeki Özen and Ömer Adrgüzel, Determining of Students' Views Regarding the Analysis of "Last Supper" by Leonardo Da Vinci Through Creative Drama by Abdulgafar Terzi and Nami Eren Beştepe, Investigation of Social Justice Attitudes of Creative Drama Trainers by Serkan Keleşoğlu and İhsan Metinnam, The Analysis of the Effect of Creative Drama Activities on Participation Levels of Elementary School Inclusive Students Diagnosed with a Learning Disability in Classroom Activities by Fatih Kıvanç Erdoğan, Süleyman Arslantaş and Ahmet Kurnaz, Students' Views on the Effects of Creative Drama in Human Relationships and Communication Course by Mustafa Yeler, The Values Education in Preschool Period Through Creative Drama by Yildiz Kaya and Serap Antepli, The Importance of Creative Drama in Social Work Education by Ecem Naz Nazher and Gizem Akoğlu.

We'd like to announce that PhD. İhsan Metinnam have started to contribute to our Journal as the assistant editor from the second issue of the thirteenth volume onwards. We wish that you will follow our publications with regards to the interaction of our instructor aspect and our fields individually with different fields of study by evaluating this issue of our Journal from the viewpoint of new studies carried out in the field of creative drama. We would like to thank our authors, who supported this issue with their works, our reviewers, who meticulously evaluated these works, and those who contributed, we wish you to join our efforts, as well.

We wish to meet you in the first issue of 2019 which will include new studies and projects to be carried out with the purpose of contributing to the field of creative drama...

\section{PhD. Ferah Burgul Adıgüzel}

\section{Editor}





\begin{tabular}{rr} 
çağdaş & Yaratıcı Drama Dergisi 2018, 13(2), 153-172 \\
drama & www.yader.org \\
\hline
\end{tabular}

\section{Okul-Gerçek Yaşam ve Sorumluluk Üstlenme İlişkisini Sorgulayan Yeni Bir Drama Yaklaşımı: Komisyon Modeli*}

Zeki Özen ${ }^{1}$

Ömer Adıgüzel ${ }^{2}$

\begin{tabular}{|c|c|}
\hline Makale Bilgisi & $\ddot{\text { Öz }}$ \\
\hline DOI: $10.21612 /$ yader.2018.012 & $\begin{array}{l}\text { Bu çalışma, drama alanı öncülerinden Dorothy Heathcote'un son dönem drama } \\
\text { yaklasımlarından olan ve drama alanında yeterince bilinmeven "Komisvon Model" }\end{array}$ \\
\hline Makale Geçmişi & yaklaşımını tanımlamak, bu tanımdan hareketle bir uygulama örneği geliştirmek ve \\
\hline 07.05 .2018 & $\begin{array}{l}\text { uygulama örneğine dahil olan ögrencilerin yaşantılarını komisyon modelin amaçları } \\
\text { doğrultusunda analiz etmek amacıvla gerceklestirilmistir. Arastırma nitel arastırma }\end{array}$ \\
\hline 15.06.2018 & $\begin{array}{l}\text { desenlerinden eylem araştırması deseniyle yapılandırllmıştır. Araştırma grubunu, } \\
\text { Ankara Üniversitesi Eğitim Bilimleri Fakültesinde 2015-2016 eğitim ögretim } \\
\text { döneminde farklı anabilim dallarında ögrenim görmekte olan ögretmen adayları } \\
\text { oluşturmuştur. Uygulama sürecinde gözlem, görüşme, görsel sunumlar,yansitıcı özetler, }\end{array}$ \\
\hline Anahtar Sözcükler & ses kaydı ve video kaydı yolu ile veriler toplanmıştır. Araştırma sürecinde toplanan \\
\hline Komisyon modeli yaklaşımı & $\begin{array}{l}\text { veriler tümevarım analizi ve içerik analizi teknikleri kullanılarak çözümlenmiştir. Bu } \\
\text { araștırmadan elde edilen bulgular, komisyon model yaklașımının gerçek yașamda }\end{array}$ \\
\hline Ĕgitimde yaratıcı drama & var olan problem durumlarını çözen, sorumluluk üreten ve sosyal etkileşim yolu ile \\
\hline Öğretmen adaylart & $\begin{array}{l}\text { işbirlikli öğrenme ortamı sunan bir yaklaşım olduğunu göstermistir. Bu bulgulardan } \\
\text { hareketle. Komisyon model uvgulamalarının drama disiplini icerisinde daha fazla ver }\end{array}$ \\
\hline Okul-gerçek yaşam ilişkisi & bulması ve okul gerçek yaşam ilişkilerinin bu anlayışla yapılandırılması önerilmiştir. \\
\hline \multicolumn{2}{|l|}{ Dorothy Heathcote } \\
\hline \multicolumn{2}{|c|}{$\begin{array}{l}\text { A New Drama Approach Questioning The Relationship Between } \\
\text { School-Real Life and Taking Responsibility : Commission Model }\end{array}$} \\
\hline Article Info & Abstract \\
\hline DOI: $10.21612 /$ yader.2018.012 & $\begin{array}{l}\text { This study was carried out to define Dorothy Heathcote's "Commission Model" } \\
\text { approach, which is one of Dorothy Heathcote's most recent drama approaches and }\end{array}$ \\
\hline Article History & $\begin{array}{l}\text { which is not well known in the field of drama. From this definition, the aim of this } \\
\text { research is to develop an application example and analyze the experiences of the students }\end{array}$ \\
\hline 07.05 .2018 & included in the application example in line with the purpose of the commission model. \\
\hline 15.06.2018 & $\begin{array}{l}\text { The research is structured by action research from one of the qualitative research } \\
\text { designs. The research group was composed of teacher candidates from different } \\
\text { departments of Ankara University Faculty of Educational Sciences in the period of } \\
2015-2016 \text {. Fourteen female and eight male teacher candidates were included in the }\end{array}$ \\
\hline Keywords & $\begin{array}{l}\text { study group. During the implementation process, the data were collected by the way of } \\
\text { observations, interviews, visual presentations, reflective summaries, voice recording }\end{array}$ \\
\hline Commission model approach & and video. The data collected during the research process were analyzed by inductive \\
\hline Drama in education & $\begin{array}{l}\text { analysis and content analysis techniques. The findings obtained from this research } \\
\text { reveal that are the commission model is an approach that solves problem situations }\end{array}$ \\
\hline Teacher candidates & in real life, produces responsibility and presents a collaborative learning environment \\
\hline School-real life Relations & through social interaction. Based on these findings; it is proposed that the commission \\
\hline Dorothy Heathcote & $\begin{array}{l}\text { model applications must find more space in the drama discipline and that school-real } \\
\text { life relations have to be structured with this understanding. }\end{array}$ \\
\hline
\end{tabular}

\footnotetext{
* $\quad$ Bu makale Zeki Özen tarafından hazırlanan "Drama Yaklaşımlarından Komisyon Modelin Öğretmen Adaylarına Okul-Gerçek Yaşam İlişkisi Kurma Becerilerini Kazandırmada Kullanımı” başlıklı doktora tez çalışmasından üretilmiştir.

1 Dr., Ankara Üniversitesi Eğitim Bilimleri Fakültesi, E-posta: ozenzeki@hotmail.com

2 Prof. Dr., Ankara Üniversitesi Eğitim Bilimleri Fakültesi, E-posta: omeradiguzel@gmail.com
} 


\section{Giriş}

Eğitim çalışmalarında doğal ortamlar oluşturma çabası sürekli tartışılan konulardan biri olmuştur. Eğitim sistemlerinde bu doğallığa ulaşmak adına farklı yollar denenmiş olsa da tartışmalar güncelliğini korumaya devam etmektedir. Bu bağlamda genel olarak “doğallık” kavramı, bireylerin gelişim dönemi özelliklerine göre tanımlanmıştır. Eğitim bilimleri geleneklerinde Rousseau, Dewey gibi filozoflar bu kavram üzerinde durmuş, eğitim ve doğallık ilişkisini “doğa” kavramı ile birlikte irdelemişlerdir.

Doğa ve çevre kavramlarının işlevsel bir öğretim aracı olabilmesi için belirli planlamalar doğrultusunda eğitim alanı ile buluşturulması gerekmektedir. Doğa ve çevreyi araç olarak kullandığımız eğitim süreçleri, dolaylı öğrenmeleri içermektedir. Daha nitelikli öğrenme süreçlerini edinmek için çevre ve doğa ortamlarını belirli amaçlar doğrultusunda donatmak gerekmektedir. Doğa ve çevrenin bir parçası olan "sosyal çevre" bu donanımın değerli bir parçası olarak düşünülebilir. Dewey (1996)'e göre sosyal çevre, bireyin duygusal ve düşünsel tutum ve davranışlarını, belli dürtüler, belli amaç ve sonuçlara ulaştıracak eylemlere kanalize ederek biçimlendirir.

Bireyin sosyal çevresi ile gerçekleştirmiş olduğu etkileşim birçok eğitim yaklaşımında ya da yönteminde önemli bir araç olarak görülmektedir. Bireylerin sosyal çevrelerini ve bu çevrede öğrendiklerini önemseyen yöntemlerden birisi yaratıcı dramadır. Drama çalışmaları, grup etkileşimine dayalı ve grup üyelerinin yaşam deneyimlerinden beslenen süreçleri içermektedir. Drama çalışmalarına katılan grup üyeleri, belirli dramatik durumlara yönelik canlandırmalar gerçekleştirerek düşüncelerini ortaya koyarlar. Sürece dahil olan bireyler, oluşturmuş oldukları sosyal etkileşimleri sağlıklı bir biçimde devam ettirmek adına kimi roller üstlenirler. Drama çalışmalarında bireyler genel olarak canlandırmaların oluşum süreçlerinde; hem kendi düşüncelerini doğru aktarmak hem de grubunda bulunan diğer bireylerin düşüncelerini doğru algılamak için uğraş verirler.

Drama uygulamalarında, işlenen konuya ilişkin üstlenilen rol çalışmalarından önce; zihinsel ve fiziksel hazırlık çalışmaları gerçekleştirilmektedir. Bu hazırlık aşamaları sırasında bireyler, yaşam deneyimlerinin zenginliği sınırında diğer katılımcılarla iletişime geçmektedirler. Bireyler; sahip olduğu deneyim zenginliklerini diğer katılımcılarla paylaşmak için kendilerini rahat ve yargısız ifade edecekleri doğal ortamlara gereksinim duymaktadırlar. Deneyim zenginliği farklı olan bireylerin, işlenen temaya ilişkin görüşlerini bildirmeleri ve paylaşıma geçtikleri diğer bireylerde var olan farklı birikim seviyelerine, sosyal etkileşim yoluyla somut bir biçimde tanık olmaları, yapılan işin "kurgusal” olduğu gerçeğini beslemektedir.

Deneyim zenginliğini kurgusal bir ortamda paylaşan bireyler, kısa bir ön hazırlık ile yaptıkları canlandırmalara inanma konusunda sorunlar yaşamaktadır. -Mış gibi yapma sürecine inanmayan bireylerin dilsel, fiziksel, mekânsal, ruhsal, duygusal, vb. açılardan rol gerekliliklerini yerine getirmedikleri görülmektedir. Rolün gerekliliğini yerine getiremeyen bireylerin "-mış gibi yapamama" durumlarının ise kurgusal ortamlardaki "inanmayışı” daha da beslediği görülmektedir. Bu gerekçeyle bireylerin role olan inanıştan daha da uzaklaştı̆̆ söylenebilir.

Estetik kaygılar, izleniyor olma durumu, canlandırılan role kültürel ve düşünsel açıdan uzak olma durumu, canlandırma yapmaya yönelik deneyim eksikliği, canlandırmalarda kendin gibi olamama durumu, heyecan, mekân, zaman, vb. gibi gerekçelerle canlandırmalarda üstlenilen rollere inanma durumu azalabilmektedir. Üstlenilen rollere yönelik gerçekleştirilen fiziksel ve zihinsel 
hazırlıkların da yetmediği durumlarda katılımcı, oynarken inanmadığı rolleri canlandırabilmektedir. Rolüne inanmayan katılımc1, rolün gerektirdiği tutumu sergileme, rolü devam ettirme gibi başlıklarda sorunlar yaşamaktadır.

Role inanış kavramı bir çok drama öncüsü tarafından önemsenmiştir. Drama alanında çalışan öncüler, kendi özgün yaklaşımlarında üstlenilen role inanışı arttırmak için deneysel çalışmalarda bulunmuş ya da farklı teknikler kullanma yoluna gitmişlerdir. Bu doğrultuda sıklıkla psikoloji alanı çalışmalarına odaklanan öncüler, doğal olarak tiyatro çalışmalarındaki yaklaşımları da gözden geçirmiş ve her iki alandan "role inanışı" destekleyecek bağlantılar bulmaya çalışmışlardır.

Sözgelimi dramanın alan öncülerinden olan Bolton’a göre, bir diğer alan öncüsü olan Brian Way (akt. Metinnam, 2016) Stanislavski'den etkilenmiştir. Öğrencilerin gelişmesine yardımc1 olabilmek için özellikle duyarlılık, yoğunlaşma ve sezgi konusunda, üçünü birbirine koşut tuttuğu drama süreçleri tasarlamıştır. Bu örneğin yanı sıra bir diğer öncü olan Dorothy Heathcote, drama oturum planlamalarını tasarlarken etkilendiği kişilere örnek olarak Bruner'i işaret etmiştir. Heathcote (Heathcote, 2010 akt. Özen, 2011)'a göre; "Drama sosyal bir sanattır - amaca odaklanmış etkileşim içerir. Bir öğretmenin sınıflarda fikir birliği elde etmeleri için çeşitli yollarla yardımcı olması gerekmektedir."

Bruner, bu yardım yolları için üç aşama belirtmektedir:

- İkonik (resimsel, görüntüler)

- Sembolik (konuşma, tarif etme, yazma) ve

- İfadeye yönelik (“-mış gibi” davranışını gerçek bir şekilde hareketle göstererek oynamak)

Drama dersinin planlamasına ilişkin Bruner'in çalışmalarını önemseyen Dorothy Heathcote; gerçek, kurgu, katılımcı rolü, -mış gibi yapma gibi başlıkları Brian Way ve Peter Slade gibi kişinin kendi duygu ve kaynaklarını oyun yaratımı sürecine aktaran Stanislavski anlayışıla değil, kişinin keşiflerini ve sonradan ortaya çıkan gösterme durumlarını öğrenme sürecine aktaran Brechtyen bir anlayışla yapılandırmaktadır (Fiala, 1977; Hesten, 1993; Eriksson, 2009).

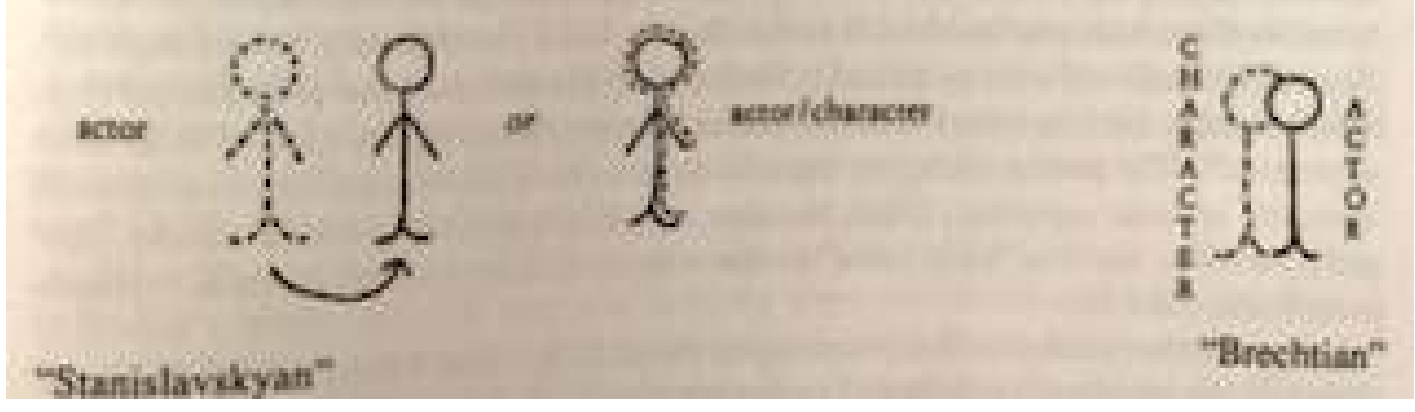

Şekil 1. Dorothy Heathcote'un etkilendiği rol anlayışı. (Fiala 1980'den akt. Erriksson, S.)

Birçok drama sınıfında drama eğitmeninin temel ilgilendiği şey; gerçek yaşam durumlarının simülasyonu sayılabilecek gerçek illüzyonlar yaratmaya çalışmaktır. Böylesine bir gelenekle yapılanan drama anlayışlarında pedagojik amaç; ya canlandırma yapan kişinin bilinçli bir psikolojik adım atarak karakterin ruhunun içine girmesidir (üst-sol çizim) ya da kendi kişiliği ile karakteri birleştirip tamamen kaynaşık bir karakter yaratmasıdır (üst-orta çizim). Heathcote’un yaklaşımlarında 
ise genel düşünce "başkası" gibi olduğuna inanmak ya da "başkası" gibi yapmak değildir. Temel amaç, kendine ait bilincini korurken bir başka kişinin inandırıcı, karakteristik tutumunu üstlenmeye çalışmaktır (üst-sağ çizim) (Eriksson, 2009).

Birçok drama yaklaşımında tartışılmak istenen temaya ilişkin derinlikli düşünce paylaşımı yeterince gerçekleştirilememektedir. Toplum için itici bir güç olabilecek drama disiplini, gerçekleştirilen rol oynamaların yüzeysel bir biçimde yapılmasından dolayı olası gücünü sınırlı bir biçimde kullanabilmektedir. Bu gerekçeden hareketle drama alan öncüleri, drama disiplininin işlevini yerine getirebilmesi ve gücünü kullanabilmesi adına yeni yaklaşımlar geliştirmişlerdir.

Dorothy Heathcote, kendi özgün yaklaşımlarında kurgu ve gerçek kavramlarını özenle işlemektedir. Farklı yaşam deneyimlerine sahip katılımcıların sosyal etkileşimini önemseyen Heathcote, katılımcılar tarafından gerçekleştirilmesi kolay sayılabilecek olan görevler ile çalışmalarına başlamaktadır. Heathcote, katılımcılarının kendilerini başarısız hissetmeyecekleri durumlar oluşturarak, onlarda özgüven yaratmaya çalışır.

Bruner'in sosyal öğrenme aşamaları ile yapılanan Dorothy Heathcote'un özgün yaklaşımlarının gereksinimler ve gelişmeler doğrultusunda belirli bir evrimsel süreç geçirdiği görülmektedir. Heathcote'un ilk zaman drama çalışmalarında çatışma kavramının odakta olduğu, insanlığa ilişkin karmaşa sayılabilecek durumlar işlenmiştir. Heathcote (1985), kendi hakkında yazılmış yazıların toplandığı kitapta; kendi yaklaşımlarının dramaturjik odağında 1980'li yıllara varıncaya değin "gerilim” kavramının yer aldığını belirtmektedir. Bu biçimdeki bir drama anlayışını ise şu biçimde tanımlamaktadır: "Drama; insanların karşı karşıya kaldıkları zorlu durumlarla mücadele etmekten dolayı, insanları değiştirebilen durumlardır.'

Dorothy Heathcote'un ilk zaman sınıf uygulamalarında görülen kurmacaların sınıf öğrencileri ile beraber, işbirliği içerisinde yapılandığı görülmektedir. İşbirliği içerisinde yapılanan tüm kurmacalarda belirli anlaşmalar göze çarpmaktadır. Belirli bir inanış oluşturmak adına öğrenciler ve Heathcote'un birlikte verdiği kararlar "Her öykünün öncesinde bir başka öykü vardır." anlayışını kabul etmektedir.

Heathcote; Kanadalı sosyolog Erving Goffman'ın tiyatro metaforlarından ödünç alarak kullandığ 1 "rol" ve "performans" gibi terimlerin bir çok farklı toplumsal bağlama aktarıldığını ifade etmektedir. Heathcote aynı anlayıştan hareketle ilk drama örneklerinde Goffman'ın “çerçeve" anlayışını kullanarak rol işlevlerini anlatan bir çerçeve sunmuştur.

Heathcote, 1989 yılında da Ulusal Drama Eğitimi Derneği tarafından gerçekleştirilen uluslararası katılımlı bir konferansta sunduğu "Drama için mücadele - Eğitim için mücadele" başlıklı konuşmasında Erving Goffman'dan etkilenerek oluşturduğunu ifade ettiği "çerçeve uzaklık" kavramına ilişkin bilgi aktarımında bulunmuştur (Eriksson, 2009).

Aslında Goffman, sosyal dünyamızın tüm yönlerini kapsayacak teorik bir yaklaşım geliştirmemis, ancak iki veya daha fazla insanın birbirlerinin fiziksel varlığından oluşan ortamlar olarak sosyal durumlar-etkileşim düzeni diye tanımladığı bağlamlara dair kapsamlı bir analiz geliştirmiştir. Bu bağlamlar diğerleriyle yüz yüze aktivitelerden oluşan, günlük sosyal durumlar, kurumsallaşmıs, yapılar (okul, iş yeri) ya da olağan dışı sosyal olayları da (düğün, kaza) kapsayacak denli genis, ve insan hayatını domine edecek kadar çeşitlidir (akt. Bayad, 2016). 
Dorothy Heathcote’un gerçek yaşam odaklı drama anlayışı, belirli bir süre sonra dönüm noktası sayılabilecek bir kararla "karmaşa içindeki insan” yaklaşımından "uzman mantosu” yaklaşımına doğru evrilmektedir. Uzman mantosu çalışmaları teorik ve bilimsel araştırmaları, performans çalışmaları ile buluşturan bir yaklaşım olarak değerlendirilebilir. Bütün sınıf öğrencilerinin işbirliği içerisinde uzmanlar, arkeologlar, mimarlar vb. roller üstlendikleri rol oynamalar olarak tanımlanmaktadır. Psikolojik açıdan bakıldığında öğrencilerin karakterlere bürünmedikleri ama üstlenilen uzmanlığın gerektirdiği ortak sorumluluk ve değerleri benimseyerek oluşturdukları rollerdir (Tor, 2008).

Heathcote yöntembiliminin toplumsal işlevi; tutumların sınanması, gerektiğinde değiştirilmesi ve öğrencilerin kişisel beklentilerinin artmasına odaklanmaktadır. Çalışmaların başlangıcında öğrenciler sembolik düşünebilmeleri için teşvik edilirler. Buna bağlı olarak öğrencilerin yaratıcılıkları sembolik grup etkinliklerine yönelerek grup içerisinde bir sorumluluk oluşmasını sağlamaktadır. Drama dersi, öğrencinin sorumluluk alma konusunda bir karar mekanizması oluşturması ve geliştirmesi bağlamında yapılanmış olur (Hesten, 1993).

Dorothy Heathcote'un özgün yaklaşımları zamandizinsel bir biçimde incelendiğinde, gerçek yaşamda dönüştürücü olma iddiasının her yaklaşımda korunduğu görünmektedir. Heathcote'un özgün yaklaşımlarından sonuncusu olan komisyon model uygulamaları ise bu iddiayı gerçekleştirmek için kurgusal ortamlardan uzaklaşarak gerçek yaşam ortamlarını kendisine mekân edinmiştir. Drama dünyası için çok cesur sayılabilecek bu adım, katılımcılarına daha gerçekçi sorumluluklar üretme için firsatlar yaratmaya çalışmaktadır.

Uzman mantosu çalışmalarında katılımcılar olabildiğince gerçek tepkiler verseler de yapılan iş ve üstlenilen görevler belirli bir kurguya dahil bir biçimde ilerlemektedir. Katılımcının vermiş olduğu doğal ve gerçekçi tepkiler; mekân kurgusu, katılımcı tepkisi, sosyal etkileşimin sınırlı olması, üstlenilen role olan uzaklık gibi başlıklarla bir biçimde bozguna uğramaktadır. Doğal ve gerçekçi sorumluluklar üretilen ama kurgu olduğu bilinen uzman mantosu yaklaşımını gerçek yaşama taşıyan komisyon uygulamaları ise her şeyiyle gerçek olan bir ortam yaratmaya çalışmaktadır.

Heathcote, dramanın özünde yer alan kurgu ve gerçek ayrımının bozguna uğradığı komisyon çalışmalarına ilişkin şu ifadeleri kullanmaktadır :

"Uzman Mantosu ve Rolün Yuvarlanması çalışmaları, öğrencilere olgun birer insan olarak kendi kapasitelerini sınama ve kuşkusuz kendi ilgi ve becerilerini gösterme olanağ 1 verir. Komisyon Modeli ise dünya işleri ve beraber öğrenmede aktif katılım diyebileceğimiz iki noktada kusursuz bir bağlantı oluşturur." (Heathcote, 2000)

Komisyon model uygulamalarının gerçek yaşamda gerçekleşiyor oluşu drama alanında kabul edilmiş bir kural olan "kurgusal canlandırmalar" başlığı ile çelişmektedir. Bu gerekçe nedeniyle komisyon model uygulamalarına drama alanında şüphe ile yaklaşılmaktadır. Araştırma kapsamında yapılan etkinlikler ile yukarıda sözü geçen şüpheye yanıt aranmaktadır. Bütün bu gerekçeler araştırmanın problem durumunu oluşturmaktadır.

\section{Araştırmanın Amacı}

$\mathrm{Bu}$ araştırmanın amacı drama alanı öncülerinden Dorothy Heathcote'un drama yaklaşımlarından olan "komisyon model" yaklaşımının odakta olduğu bir uygulama örneği geliştirmek ve uygulama örneğine dahil olan öğrencilerin yaşantılarını komisyon model amaçları doğrultusunda analiz etmektir. 


\section{Araştırmanın Önemi}

$\mathrm{Bu}$ çalışma; gerçek yaşamda oluşan etki-tepki alıverişlerinin kurgusal ortamlarda deneyimleyen, alışılagelmiş drama yaklaşımlarından farklı olarak gerçek yaşamda kurgulanmış dramatik durumları içermektedir. Komisyon model uygulamalarının temel felsefesi; eğitim ve eğitimde drama çalışmalarını gerçek yaşamla buluşturmaktır. Bu yönüyle "komisyon model" drama dünyası için yeni bir yaklaşım olarak görülmektedir. Bir çok drama alan uzmanının henüz yeterince tanımadığı "komisyon model" yaklaşımının ayrıntılarını belirlemek ve uygulama örneği ile beraber komisyon model yaklaşımını ortaya koymak drama alanı açısından önem taşımaktadır. Bu bağlamda araştırma; dünyada bu başlıkta gerçekleştirilen sayılı çalışmalardan biri olması açısından önemlidir.

\section{Yöntem}

\section{Araştırma Modeli}

$\mathrm{Bu}$ çalışma, nitel araştırma desenlerinden eylem araştırması deseniyle yapılandırılmıştır. Eylem araştırması, bir okulda çalışan yönetici, öğretmen, eğitim uzmanı veya diğer tür kuruluşlarda çalışan mühendis, yönetici, planlamacı, insan kaynakları uzmanı gibi bizzat uygulamanın içinde olan bir uygulayıcının doğrudan kendisinin ya da bir araştırmacı ile birlikte gerçekleştirdiği ve uygulama sürecine ilişkin sorunların ortaya çıkarılmasını ya da halihazırda ortaya çıkmış bir sorunu anlama ve çözmeye yönelik sistematik veri toplamayı ve analiz etmeyi içeren bir araştırma yaklaşımıdır (Yıldırım, \& Şimşek, 2013).

Eylem araştırması, problem çözmeye yönelik ve süreklilik gösteren bir süreçtir. Bu Schön'ün (1983) tanımladığı "yansıtıcı düşünme” ile benzerlik gösterir. Yansıtıcı düşünmeyi bir sorgulama süreci olarak tanımlayan Schön, bu sürecin bir problem durumuyla başladığını, belirli değişiklikler yoluyla bu problemin çözüldüğünü ve bu aşamada üzerinde düşünülecek yeni problemlerin belirlendiğini belirtmektedir. Benzer şekilde eylem araştırması süreci; problem belirleme, veri toplama, veri analizi, eylem planı belirleme, eylemi gerçekleştirme ve alternatif ya da yeni bir eyleme karar verme aşamalarından oluşmaktadır (akt: Yıldırım, \& Şimşek, 2013).

\section{Çalışma Grubu}

Çalışmanın araştırma grubunu, Ankara Üniversitesi Eğitim Bilimleri Fakültesi'nde 20152016 eğitim öğretim döneminde farklı anabilim dallarında öğrenim görmekte olan öğretmen adayları oluşturmaktadır. Çalışma grubunda yer alan öğretmen adayları aynı zamanda kısa adı EYAT olan Eğitimde Yaratıcı Drama Topluluğunun gönüllü katılımcılarıdır. Çalışma grubunda on dört kadın, sekiz erkek öğretmen adayı bulunmaktadır. Çalışma evreninin oluşturulmasında amaçlı örnekleme yöntemlerinden uygun durum örneklemesi tercih edilmiştir. Uygun durum örneklemesi, deney grubunun kolay ulaşılabilir olmasıyla ilişkilidir (Ekiz, 2009). 


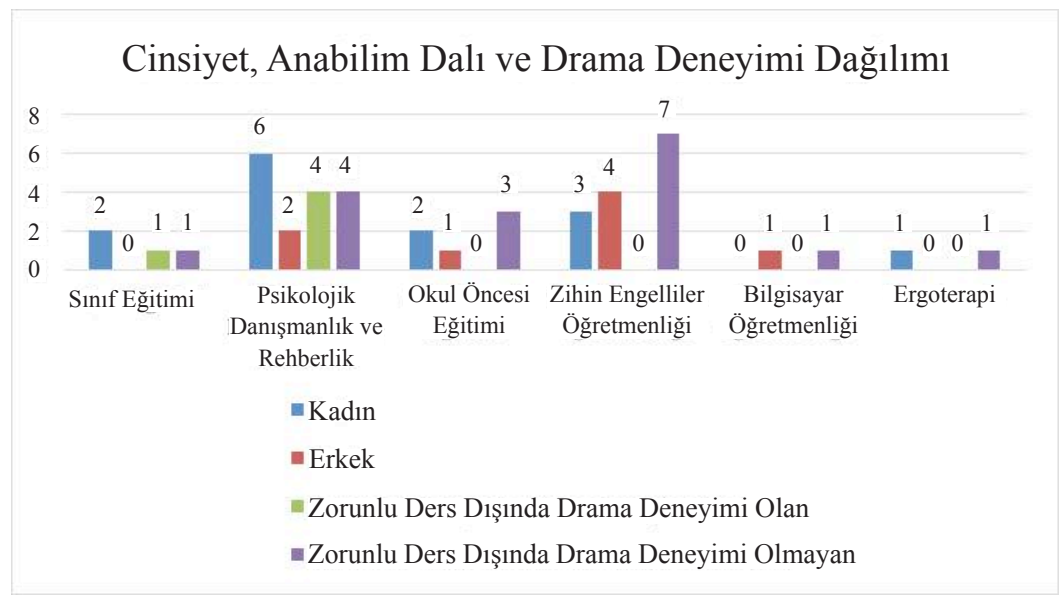

Grafik 1. Cinsiyet, Anabilim Dalı ve Drama Deneyimi Dağılımı

\section{Veri Toplama Kaynakları, Araçları ve Yöntemleri}

Eylem araştırmasında sistematik veri toplama süreci gerçekleştirildiğinden, araştırmaya başlamadan önce ne tür verilerin, nasıl ve ne sıklıkta toplanacağına karar verilir (Kuzu, 2005). Toplanan verilerin niteliğini arttırmak amacıyla çeşitli veri kaynaklarından veri toplanmıştır. Araştırmanın asıl çalışma grubu olan öğrenci grubunun yanı sıra öğrenci grubunun temas ettiği diğer paydaşlardan toplanan veriler de çalışmaya yön vermiştir. Bu doğrultuda araştırma grubu öğrencileri, yaşadıkları süreci yansıtan raporlar oluşturmuştur. Süreç sonunda araştırma grubu ile odak grup görüşmesi gerçekleştirilerek veriler çeşitlendirilmiştir.

\section{Verilerin Toplanması}

Çalışma grubunun araştırma süreci içindeki yaşantıları, gerçek yaşam içerisinde yer alan bir yapılanmayı sahiplenmeleri, bu sahiplenmenin kırıldığı noktalar ve gerekçeleri, kendi grupları içerisinde yaşadıkları öznel durumlar ve hissettirdikleri, araştırma grubunu motive eden ve güdüleyen etmenler gibi durumlar irdelenmeye çalışılmıştır. Bu başlıkların yanı sıra öğrenci topluluğunun araştırma süreci içerisindeki kendi yaşantılarından yola çıkarak, "komisyon model" yaklaşımını tanımlamaları istenmiştir. Son olarak katılımcılardan çalışma içerisinde yer alan gerçek ve kurgusal durumların sorumluluk üretme noktalarında nasıl, ne biçimde etkili olduğuna ilişkin değerlendirme yapmaları istenmiştir. Tüm çalışmalar bittikten sonra araştırma grubu tarafindan çalışma istemcisi olan Ankara Üniversitesi Sağlık, Kültür ve Spor Daire Başkanlığı’na genel bir rapor hazırlanmıştır. $\mathrm{Bu}$ rapor çalışmanın diğer paydaşlarından toplanan istekleri de doğrudan içermektedir.

Raporlar teslim edildikten sonra yaşanan süreci daha ayrıntılı betimlemek ve araştırma grubunun dinamiklerini ortaya koymak amaciyla odak grup görüşmeleri gerçekleştirilmiştir. Farklı zamanlarda gerçekleşen üç “odak grup görüşmesi” katılımcıları olabildiğince farklı alt çalışma gruplarından seçilmiştir.

\section{Verilerin Analizi}

Elde edilen nitel verilerin analizi için metinlerden yola çıkarak kodlamalar yapılmıştır. Kodlama süreci metin veya görsel verileri küçük bilgi kategorileri içine toplamayı, bir çalışmada kullanılan farklı veri tabanlarından gelen kod için kanıt aramayı ve sonra koda bir etiket vermeyi 
içermektedir (Creswell, 2013). Araştırmacı tarafından verilen kodların yanına alınan anımsatıcı notlar kategorileri belirlemede yardımcı olmuştur. Oluşan kategorilerde kesişen ortak noktalar belirlenerek temalar oluşturulmuş ve oluşturulan temalar yorumlanmıştır.

\section{Bulgular}

\section{Uzman Mantosu Yaklaşımı ile Kültür Sanat Merkezi Oluşturuyoruz}

Araştırmanın bu aşamasında öncelikle araştırma grubu üyelerinin uzman mantosu uygulamalarına yönelik düşünceleri ve yaşantıları kendi ifadeleri üzerinden değerlendirilmiştir. Grup üyelerinin ifadeleri analiz edildiğinde özellikle kazanımlar, kendi motivasyonlarını düşüren etmenler, komisyon modele hazırlık süreci, rol ve gerçeklik ilişkisi, gerçekleştirilen ön hazırlıklar başlıkları üzerinden temalar oluşturulmuştur. Grup üyelerinin ifade etmiş olduğu deneyimlerden elde edilen verilerin birbirileri ile ilişkisini ortaya koyan bir harita oluşturulmuştur. Oluşturulan bu harita ile katılımcıların çalışmaya yönelik düşünce ve yaşantıları görselleştirilmiştir.

Alan çalışmalarına geçilmeden önce gerçekleştirilen uzman mantosu çalışmalarının, araştırma grubu üyelerini olumlu bir biçimde etkilediği gözlemlenmiştir. Uygulama sırasında araştırma grubu üyeleri, bir kültür sanat merkezinde yer alabilecek tüm ayrıntılara ilişkin derinlikli düşünceler üretmiş ve araştırmışlardır. Bu nedenle kurgusal bir ortamda yapılandırılan uzman mantosu uygulamalarının katılımcıların bilgi evrenine ve yaşam deneyimi paylaşımına katkı sağladığına inanılmaktadır. Uzman mantosu sürecinde araştırmacı grubun bilgiye ulaşması amacıyla işbirlikli çalışmalar yürütmesi için uygun bir motivasyon ortamı yaratılmaya çalışılmıştır. Bu nedenle araştırma grubu üyelerinin uzman mantosu uygulamasına yönelik düşünceleri ayrı bir biçimde ele alınmıştır. Araştırma grubunun uzman mantosu uygulamasına yönelik değerlendirmeleri şu biçimde haritalandırılmıştır:

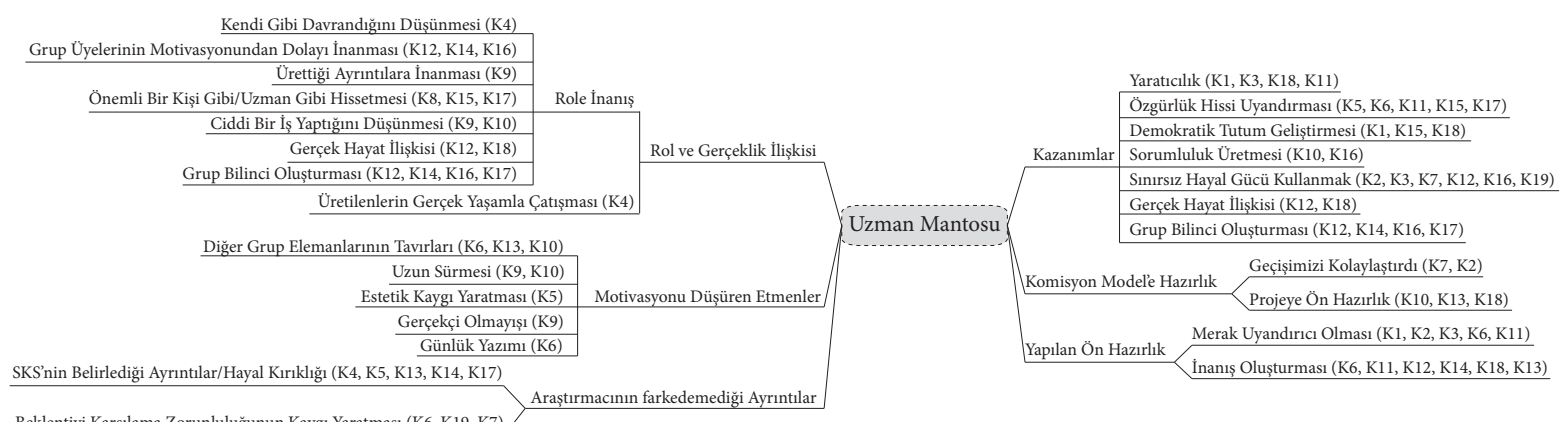

Şekil 2. Araştırma Grubu Üyelerinin Uzman Mantosu Uygulamasına Yönelik Düşünceleri

\section{Alan Çalışmaları Başlıyor: Komisyon Model Uygulamasına Yönelik Görüşler}

Uzman mantosu çalışmalarının ardından komisyon model uygulamasının diğer etkinliklerinin uygulanması aşamasına geçilmiştir. Katılımcıların alan çalışmalarına yönelik betimlediği cümleler kategorileştirilmiş ardından da üst temalara ulaşılmıştır. Belirlenen üst temalarda yer alan ifade sıklıkları katılımcıların söylemlerine göre haritalandırılmıştır

Komisyon model uygulamalarının temel anlayışında yer alan; gerçek insanlarla temas ve gerçek dramatik durumlarla baş etme durumu, grup üyelerinin ayrıntılı düşünmelerini sağlamıştır. Uzmanlar tarafindan ifade edilen ayrıntılar ve alanda temas edilen insanların beklentileri yeni 
öğrenme başl1kları oluşturmuştur. Böylece araştırma grubu üyelerinin daha önceden düşünmediği ayrıntılar yaşam deneyimi ve paylaşımı yolu ile bir sonraki uygulama adımına aktarılmıştır.

Alan çalışmalarında iletişime geçilen insanların aktarımları, araştırma grubu üyelerinin Kültür Sanat Merkezi bölümlerine ilişkin ufuklarını geliştirmiştir. Araştırmanın yöntemi olan eylem araştırması yönteminin anlayışında olduğu üzere grup üyeleri alan çalışmalarının bir sonraki adımını alandan elde ettikleri veriler üzerinden yapılandırmışlardır. Grup üyelerinden bazılarının alanda gerçekleştirilen etkileşimlerle ilgili olarak belirttiği ifadelerden bazıları şu biçimdedir:

K1: Her toplantıda bir sonraki adımımızı belirleyerek planımızı yapıyorduk. Gruplara ayrilarak Ankara'daki Kültür merkezlerini gezdik. Gezdiğimiz yerlerde çektiğimiz video ve fotoğrafları topluluğa sunduk. Bilgi paylaşımlarında bulunduk. Olumlu-olumsuz yönlerini konuştuk. Neleri elimizde tutmalıydık. Duvarda asılı duran küçük bir çerçeve bile bizim için önemliydi. Kaldı ki ışıklandırma, duvar rengi, parkeler... Artık her şeyi daha ayrıntılı düşünüyorduk ve elimizde somut bir mekanımız vardı. Şunun da önemli olduğunu düşünerek vurgulamak istiyorum; uzman mantosunda yaptığımız çalışmaları her zaman cebimizde tuttuk.

K11: Kültür evinin yapılandırılmasında ilk adım olarak Ankara'daki Kültür Sanat Merkezlerinin gezip bilgi toplanması bu bilgiler doğrultusunda fikirlerimizi geliştirmeyi planladık. İlk olarak gidilen yer Mamak Kültür Merkezine gidildi. Sonra Bambu Kültür Evine sonrada Kore Kültür Merkezine gidildi. Bunların arasından benim en sevdiğim Kore Kültür Merkezi oldu çünkü modern bir görünüme sahipti ve ilgi çekiyordu. Buralara giden arkadaşlarımız fotoğraflarla videolarla sunum yaptılar ve hep beraber bu yerlerin artıları eksileri üzerine konuştuk.

Araştırma grubu üyelerinin farklı alan çalışmalarına yönelik olarak belirtmiş oldukları bu deneyim ifadeleri, var olan düşüncelerinin başka deneyimlerden olumlu bir biçimde etkilendiğini göstermektedir. Alan çalışmaları sırasında oluşan bu etkileşimler, ayrıntı düşünmenin yanı sıra üyeler için öğretici ortamlar da yaratmıştır. Araştırma grubunun etkileşimli temaslar yolu ile öğrendiklerine ilişkin görüşlerinden bazıları şöyle örneklendirilebilir:

K1: Ayrıca her gittiğimiz yerden farklı bir şey öğrendik. Salonlarının adlandırılmasını, kursların zamanlarını nasıl ayarladıklarını öğrendik. Aslında daha önce Cermodern dışında bir yere gitmemiştim. Kültür merkezleri konusunda çok bilgili değildim. Bu çalışmalarla birlikte birçok şey öğrendim. İlgim arttı. Farkındalık kazandım. İlk başladığımızda kültür evi deyince aklıma pek bir şey gelmiyordu. Hatta hepimiz arama motoruna yazıp bir bakmıştık. Şu anki noktamıza baktığımızda orada yazanların ne kadar sınırlı olduğunu görüyorum. Bir kültür merkezi orada yazanlardan ibaret değilmiş. Çok kapsamlı, ayrıntılı çalışmalar gerektiriyormuş.

K9: Ankara' daki kültür evleri nası1, neler yapıyorlar görmek adına yaptığımız kültür evi ziyareti deneyimimden bahsetmek istiyorum. Kültür evinin sahibi çok ilgiliydi. Sorularımı dikkatle dinledi. Özenle cevaplar verdi. Bambu kültür Evi dediğimiz yer eski bir apartmanın son katında odaları bölümlere ayrılmış bir yer. Ama içinde inanılmaz güzel etkinlikler gerçekleşiyor. Kültürevi sahibine, üç katlı birçok odası olan bir binadan bahsedince hayretler içerisinde kaldı. Neler neler yapardım orda dedi. Haklıydı çünkü kendisi yaklaşık beş odası ve küçük bir terası olan katta çok güzel etkinlikler gerçekleştiriyordu. Öğrendik ki binamızın eski olması o kadar da kötü bir durum değildi. 
K14: Oradaki sorumlu kişiyle yarım saate yakın bir röportaj yaptık. Bu röportaj çok faydalı oldu. Bu kültür merkezinde insanların neleri sevip sevmediği açık olarak söyledi. Salona gittiğimiz zamanda diğer arkadaşlar da farklı kültür sanat evleriyle ilgili topladıkları bilgileri bizlerle paylaştılar. Bu paylaşımlar çok faydalı oldu. Çünkü birçok kültür merkezine ilişkin fikir sahibi olmuştuk.

Araştırma grubu üyeleri, alan çalışmalarında yaşamış oldukları bu deneyim paylaşımlarından edindikleri bilgiler aracılığı ile yeni bir bilgi evrenine ulaşmışlardır. Grup üyelerinin paylaşmış olduğu alan deneyimleri ve birbirlerine yapmış oldukları sunumlar, öğrenme düzeylerine yeni bir boyut kazandırmıştır. Doğrudan alan çalışmaları ile gerçekleşen bu öğrenmelerin, araştırmanın diğer aşamalarında yapılan etkinliklerin niteliğini belirlediği görülmektedir. Sözgelimi bir kültür sanat merkezinin sorumlusu ile görüşmelerde bulunmak, grup üyelerine daha önceden düşünmedikleri ayrıntılara ilişkin bir görgü kazandırmıştır. Yeni yaratımlarını bu öğrenmelerden yararlanarak devam ettiren grup üyeleri, alanda karşılaştıkları ve soru yönelttikleri bireylerden yeni bilgiler edindikleri durumlar da yaşamışlardır. Sözü edilen bu etkileşimli bilgi edinme süreci, komisyon model uygulamasının tüm alan çalışmalarında gözlemlenmiştir. Bu bağlamda araştırma grubu üyeleri yeni öğrenmelerden edindikleri deneyimleri bir sonraki çalışmaya aktarıp yine alan çalışmalarına çıkmışlardır. Var olan veri toplama araçlarını gözden geçirip, düzenlenmiş yeni veri toplama aracı ile alana çıkmanın kendilerine katkı sağladığını ifade etmişlerdir.

K5: Saha çalışmalarından sonra yaptıklarımızı gözden geçirdik hatta biz fotoğraf atölyesini baştan yarattık. Bu konuda da hiçbir şey bilmediğim bir kez daha anladım.

K9: Saha çalışmasının en güzel yanlarından biri insanlarla temas etmekti. Dönüt almamız almamamız değildi problem. Bazen alamamak da başka bir çıktıya götürüyordu.

K11: Alana çıkıp önce neler düşündügüumüzü anlattık ardından sorularla öğrencilerden veri topladık.İlk alana çıkışımızda biraz acemi kaldığımızı söyleyebilirim. Sorularımızın kısıtlı ve onay almak istercesine olduğunu daha sonra fark ettik. Alana çıkıp veri toplamak bence çok değerli çünkü farklı deneyimler, fikirler, bakış açıları eksikliklerimizi görmemizi ve geliştirmemizi sağlıyor.

Araştırma grubu üyelerinin yukarıda yer alan ifadelerinden hareketle, alan çalışmalarının esnek ve değişken bir yapıda olduğu görülmektedir. Komisyon model uygulaması anlayışında odakta olan gerçek insanlarla temas ve deneyim paylaşımlarının grup üyelerinin öğrenme sürecini olumlu bir biçimde etkilediği gözlemlenmiştir.

Araştırma grubu üyelerinin komisyon model uygulamalarında yaşadıkları süreçlere yönelik ifadeleri incelendiğinde; bir başka üst başlık olarak grup çalışmaları göze çarpmaktadır. Araştırma grubu üyeleri, grup çalışmalarına yönelik olumlu ve olumsuz ifadelerde bulunmuş ve bu ifadelere yönelik gerekçeler sunmuşlardır.

Grup üyelerinin birbirleri ile etkileşimli bir biçimde gerçekleştirdikleri alan çalışmalarına yönelik yaşamış oldukları çatışmaların ve sorumluluk paylaşımlarının kimi zaman grup üyelerinin motivasyonunu olumsuz bir biçimde etkilediği gözlemlenmiştir. Bu bağlamda grup çatışmalarına yönelik öne çıkan görüşler şu biçimdedir:

K12: Mesela en son yaptığımız Cermodern ve Salt Ulus gezisinden başlamak istiyorum. Öncesinde gidecek kişilerin uygun olduğu saatler belirlenmişti ve itirazda bulunan olmamıştı 
ama gitmeden bir gün öncesinde gruba yazdığımda herkesin bir işi çıkmıştı ve sanki sormasaydık hiç söylemeyecek gibilerdi gerçi sormamıza rağmen hiçbir şey demeyenlerde vardı ve bu beni açıkçası çok kızdırmıştı.

K19: Bu konuda en büyük dezavantajımız bence ekip üyelerinin birbiriyle fazla samimi olması, böyle olduğu için "İlla gruptan biri yapar" diyerek herkesin birbirine sorumluluğu attı̆̆ını ve aksattığımızı düşünüyorum.

Araştırma grubu üyelerinin birbirileri ile olan iletişimini olumsuz etkileyen bu tür sorumluluk üstlenme durumlarının, özellikle çalışmanın sonlarına doğru daha yoğun bir biçimde kendini gösterdiği gözlemlenmiştir. Grup çalışmalarında gözlemlenen bir diğer olumsuz tema ise grup üyeleri ile ortak yollar üretmenin zorluluğu başlı̆̆ında toplanmıştır. Dramatik açıdan incelendiğinde çözümlenmesi gereken bir problem durumu yaratan bu anlaşmazlıklar araştırma grubu üyelerinin belirgin gerilimleri arasında yer almaktadır. Bu başlıkta öne çıkan katılımcı görüşleri ise şu biçimde ifade edilmiştir:

K3: Grup arkadaşlarımın en basitinden koltuk rengini belirlerken bile kendi istedikleri kabul edilmediğinde çalışmaya olan motivelerinin o gün içinde düştüğünü gözlemleyebiliyordum. Orta yolu bulmaya çalışmak böyle durumlarda bazen beni yoruyordu.

K6: En çok sıkıntı yaşadığım nokta grupla birlikte bir şeyler yapma zorunluluğu hissetmiş olmamdı aslında ortak bir yerde buluşamıyorsak teker teker alana çıkı sonra bunları birleştirerek bir ortak noktaya varılabilirdi.

Araştırma grubu üyelerinin bir diğer olumsuz duyguya evrildiği başlık ise küçük gruplarla çalışma durumudur. Uzman mantosu sürecinde bir çok çalışmada birlikte üretimlerde bulunan araştırma grubu üyeleri, komisyon model uygulamalarında çok fazla bölüme odaklandıkları için küçük gruplar halinde çalışmalarını sürdürmüşlerdir. Daha önceden tüm grupla yapılan çalışmalarda kendilerini daha iyi hisseden bazı araştırma grubu üyeleri, diğer küçük grupların motivasyonlarını ve elemanlarını kendi motivasyonları ve grup elemanları ile karşılaştırmaya başlamışlardır. $\mathrm{Bu}$ bağlamda oluşan yeni küçük grupların işleyişine ilişkin eleştirel ifadelerde bulunmuşlardır.

K8: Çalışma salonunu tasarlarken bir süre sonra yeni şeyler üretemediğimizi fark ettim. Bunun nedenini de yine az kişi olmamıza ve aynı şeylerle uğraştığımız için hayal gücümüzün tükendiğine inanıyorum. Keşke çalışma esnasında ara ara grup değişikliği yapsaydık diyorum. Bunun bizim hayal gücümüzü canlı tutacağına inanıyorum.

K9: Komisyon çalışmasına kendi öznelim dışında bakmam gerekirse EYAT' ın enerjisini düşüren zamanları oldu. Bunda gruplara ayrılmamız ve birimlere ayrıldığımız gruplarla sürekli haşır neşir olmamız neden gösterebiliriz. Bu küçük grupların her birinin enerjisi aynı değildi.

Küçük grupların gerçekleştirdikleri çalışmalar; kimi grup üyeleri tarafından olumlu biçimde değerlendirilmiştir. Bu ifadeler katılımcıların kendilerine ilişkin fark ettikleri olumlu kazanımlarla beraber yorumlanmıştır. Araştırma grubu üyeleri edindikleri kazanımlar içerisinde komisyon model uygulamalarının sorumluluk bilincini geliştiren bir yaklaşım olduğu, işbirlikli öğrenmeyi sağlayan ortamlar oluşturduğu, özgüven kazandırdığı, katılımcısını değerli hissettirdiği, konuşma becerisini geliştirdiği, disiplinli-planlı çalışmayı öğrettiği ve ayrıntılı düşünmeye olanak sağladığı gibi kazanımlardan söz etmişlerdir. 
Araştırma grubu üyelerinin ifadelerinden hareketle komisyon model uygulamasının sorumluluk bilinci ürettiğine yönelik ifadelere sıkılıkla rastlanmaktadır. Bu yanı ile uzman mantosu yaklaşımı ile karşılaştırıldığında komisyon model yaklaşımının Dorothy Heathcote'un iddia ettiği biçimde daha fazla sorumluluk ürettiği sonucuna varılmıştır. Grup üyelerinden bazılarının sorumluluk üretimine yönelik ifadeleri şu biçimde göze çarpmaktadır:

K1: Komisyon çalışması disiplin, sorumluluk ve zaman gerektiriyordu. Her şeyi zamanında, işbirliği içinde yapmamız gerekiyordu. Elimden geldiğince yaptım.

K12: Bana kattı̆ğ iyi yönlerini; ortak kararlar almak ve bunları uygulayabilmek, kendini plana uygun yönlendirebilmek, sorumluluk almak, insanları alttan almaya çalışmak olarak siralayabilirim.

K19: Komisyon çalışmasının bana bu süreçte çok şey kattığını düşünüyorum. Ekip çalışmasının grup olmanın nasıl olduğu veya neler olursa ekip çalışması yapılamaz hale gelir onu öğrendim. Sorumlu birey olmanın önemli olduğunu fark ettim ve biraz bu konuda kendimde düzeltmeler yaptım.

Grup üyelerinin sorumluluk üstlenmeye yönelik ifade etmiş oldukları kazanım cümlelerinin diğer kazanım cümleleri ile karşılaştırıldığında daha sıklıkla kullanıldığı görülmektedir. Sıklıkla ifade edilen bu düşünceden hareketle, gerçek yaşam içerisinde yer alan bir problem durumunu çözmeye yönelik olarak yaşanılan durumların daha fazla sorumluluk ürettiği söylenebilir. Kişisel farklardan dolayı yaşanan grup içi çatışmaların nedenleri incelendiğinde; sorumluluk üretilmesi, paylaşılması gibi başlıklarla karşılaşılmaktadır. Disiplinli ve programlı çalışma durumları da sorumluluk üstlenme başlığ 1 ile beraber kullanılmıştır. Belirli süre içerisinde gerçekleştirilmesi gereken bir işi, işbirlikli bir biçimde küçük gruplar halinde tamamlama sorumluluğu disiplinli ve planlı çalışmayı beraberinde getirmektedir. Komisyon model çalışmalarının uygulama kuralları içerisinde yer alan; belirlenen işi zamanında teslim etme ve yayınlama durumunu disiplinli çalışmayı beraberinde getirmektedir. $\mathrm{Bu}$ bağlamda öne çıkan bazı katılımcı düşünceleri şu biçimdedir:

K3: Planlı çalışmanın önemini komisyon çalışması bana en iyi şekilde öğretti. Kendi yaşamımızdaki diğer yoğunluklar ne kadar çok da olsa planlı olursak bu çalışmaya da en iyi şekilde vakit ayırabileceğimi gördüm çünkü.

K13: Çalışmalar aslında bana bundan sonraki herhangi bir çalışmamda nasıl planlı ve programlı bir şekilde yol kat edebileceğimi gösterdi. Plan program konusunda bana katkı sağladi.

Araştırma grubu üyelerinin komisyon model uygulamalarında gerçekleştirdikleri alan çalışmaları, belirli düzeyde organizasyon becerisini önemseyen çalışmalar üzerinden yürümektedir. $\mathrm{Bu}$ nedenle çalışmalara katılan araştırma grubu üyelerinden daha fazla sorumluluk üstlenen üyelerin disiplinli olma konusunda daha belirgin tavırlar sergiledikleri gözlenmiştir. Kimi gruplarda sorumluluk alan ve planlı çalışmayı benimseyen katılımcıların diğer katılımcıları da olumlu etkiledikleri görülmüştür.

Alan çalışmalarında gerçekleşen başka insanlara temas etme durumu; grup üyelerinin tanımadıkları insanlarla iletişim kurmalarını gerektiren ortamları oluşturmuştur. $\mathrm{Bu}$ bağlamda araştırma grubu üyeleri; Ankara Üniversitesi Kültür Sanat Merkezine yönelik veri toplamaya çalışmışlar ve birçok insan ile görüşmeler gerçekleştirmişlerdir. Alan çalışmalarında veri toplamaya çalışan grup üyelerinin insanlarla gerçekleştirdikleri görüşme aşamalarının temel düzeyde; kendini 
tanıtma, çalışma amacını belirtme, soru ya da veri toplama aracını gerçek kişilerle buluşturma, yaşanan sorun ve anlaşılmama durumlarında anlık çözümler üretme, vb. gibi aşamaları içerdiği söylenebilir. Komisyon model uygulamalarının, araştırma grubu üyelerinin alan çalışmalarında özgüvenli bir biçimde iletişim kurmalarını sağladığg söylenebilir.

K3: Kişilerarası ilişkilerimde, konuşma becerimde dahi komisyon çalışmasının bir sürü etkisi oldu. Normalde tanımadığım insanlarla konuşmak, onları beni dinlemeye yöneltmek benim için zor bir şey iken komisyon çalışmasında alana indiğimde kendimde bu konuda olumlu değişmeler gördüm.

K4: Ben ilk kez bir insanı durdurup sorular sormak için izin isteyecektim ve nasıl bir tepkiyle karşılaşacağımı bilmediğim için biraz çekingendim. Neyse en sonunda bir cesaret yapabileceğimiz insanları gözümüze kestirip gittik. Ve anket yaptığımız nerdeyse bütün insanlar çok tatlıdı ve bizi hiç kırmadılar.

K16: Çalışmanın getirileri oldukça fazlaydı. Öncelikle alana çıktığımızda kişiler arası ilişkiler olarak geliştirdiğimiz yönler oldu. Bazen hiç tanımadığımız ne tepki vereceğini bilmediğimiz kişilerle konuştuk, ses kaydı, video fotoğraf rica ettik. Çok büyük sıkıntılarla karşılaşmadık.

Komisyon model çalışmalarının araştırma grubu üyeleri tarafından değerlendirilmesi sonucunda ortaya çıkan başlıklardan bir diğeri de araştırma grubu üyelerinin kendilerini değerli hissettiklerine ilişkindir. Bu doğrultuda grup üyeleri; alan çalışmalarında kendilerine verilen tepkiler ve uzman kişilerin çalışmaya yönelik cümlelerinden hareketle değerli hissettiklerini belirtmişlerdir.

K4: Böyle bir çalışmada yer aldığım için kendimi değerli hissediyorum çünkü fikirlerimiz önemseniyordu. Dolu dolu bir sene geçirdik ve her aşamasında çok güzel işler çıkarttı̆̆ımızı düşünüyorum.

K5: Bundan sonra rektörümüz ile görüşmeye gittik. Bu görüşmeye gitmek beni gerçekten çok mutlu etti, iyi ki ben de gidebildim dedim. Bu konuşma bana birçok şey kattı. Kültür evine nasıl baktığını, neler düşündügünü öğrendik. Rektör bey ile görüştükten sonra kendimi önemli hissettim. Rektör beyle konuştuklarımızı diğer arkadaşlarımızı da aktardık.

K9: Tüm bunların yanında bir yöneticinin tüm düşüncelerimizi ilgiyle dinlemesi, fikirlerimizi çok önemsemesi bana kendimi çok iyi hissettirdi.

Grup üyelerinin komisyon model uygulaması süresince gerçekleştirmiş oldukları etkinliklere yönelik duydukları bu hisler çalışmaya olan inançlarını arttırmıştır. Öğrencilerin yaptıkları işler, temas ettikleri insanlar ve uzmanlar, ürettikleri düşünceler, bu hislerden olumlu bir biçimde etkilenmiş ve daha nitelikli süreçler yaşamalarını sağlamıştır. Grup üyelerinin yaptıkları işlerin onay alması ve takdir görmesi çalışmayı sahiplenmelerini sağlamıştır.

Araştırma grubu üyelerinin ortaya koymuş olduğu bu düşünceler, komisyon model uygulamalarının katılımcısını değerli hissettiren bir yapıya sahip olduğunu göstermektedir. Kendisini değerli hisseden katılımcının yapmış olduğu işe daha fazla sahip çıktığı gözlemlenmiştir. İşine sahip çıkan grup üyeleri çalışma süresince sorumluluk üstlendiklerini ifade etmişlerdir. Üstlenilen bu sorumluluk, grup üyelerinin daha planlı ve özenli çalışmasına katkıda bulunmuştur. Araştırma grubunun sözel ifade becerilerini de olumlu bir biçimde etkileyen komisyon model uygulamaları; gerçek yaşam ile temas noktasında, ayrıntılı çalışmaların uygulanmasına olanak sağlamıştır. 
Komisyon model uygulamalarının katılımcısında yarattığı izlenim incelendiğinde; grup üyelerinin kendilerini değerli hissettikleri temas alanlarının oluştuğu gözlemlenmişsir. Ankara Üniversitesi Kültür Sanat Merkezi binasının yapımına katkı sağladığı düşünen araştırma grubu üyeleri; uzmanlarla gerçekleştirdikleri görüşmeler ve alan çalışmalarının ardından kendileri gibi davrandıkları gerçekçi durumlar üzerinden, gerçekçi duygular geliştirmişlerdir. Grup üyelerinin birbirleri ile yaşadıkları yakın iletişim problemlerinin yaratmış olduğu olumsuz duygular ve zaman zaman süreçten sıkılma durumlarının dışında, gerçekleştirilen tüm alan çalışmalarının sunmuş olduğu diğer ortam ve temasların yoğunlukla grubu motive edici bir duygu yarattığı gözlemlenmiştir. Araştırma grubu üyelerinin ifadelerinden hareketle komisyon modele yönelik oluşturulan veri analizlerinin haritalandırılması şu biçimde oluşmuş̧ur :

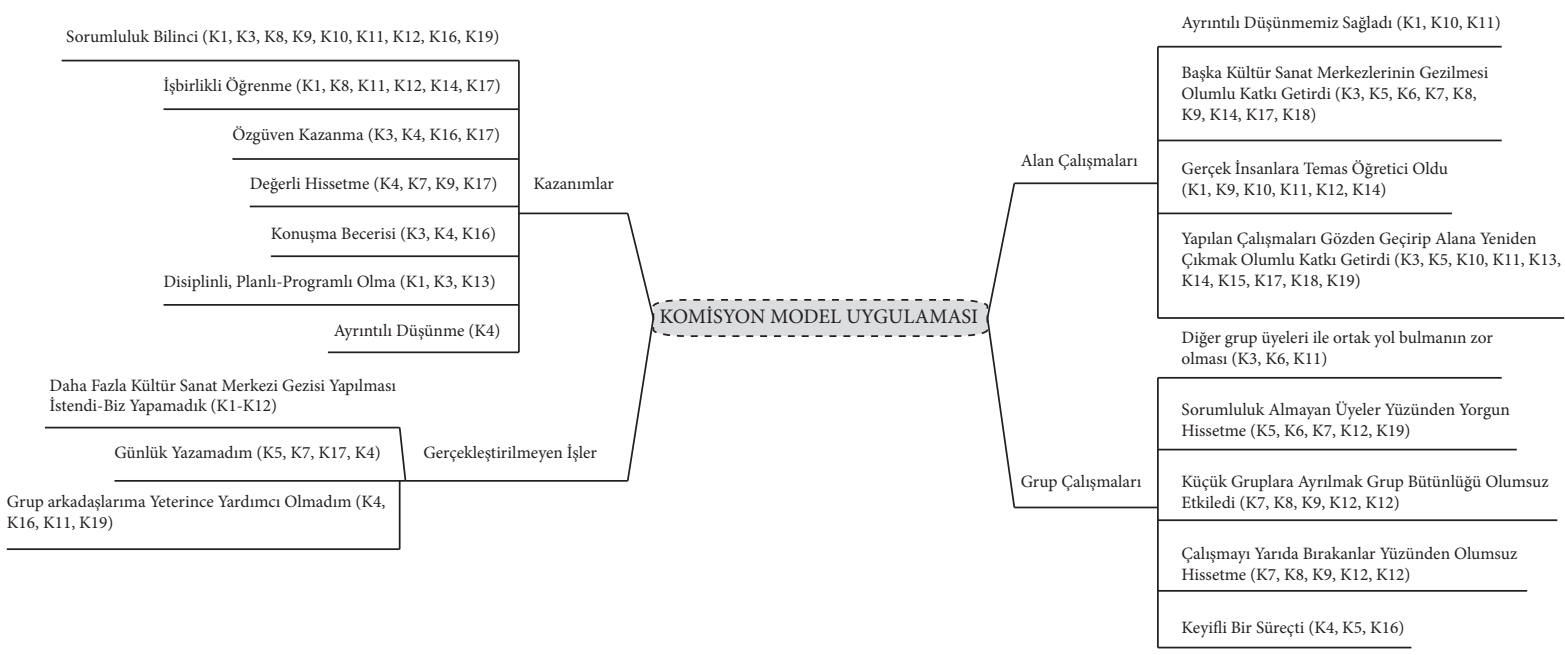

Şekil 3: Araştırma Grubu Üyelerinin Komisyon Model Uygulamasına Yönelik Düşünceleri

\section{Odak Grup Görüşmelerimiz Eksik Kalan Duygu ve Düşüncelerimizi Tamamlıyor}

Grup üyelerinin araştırma sürecinde yaşamış oldukları durumlar ve bu durumların oluşturduğu duygu durumlarına ilişkin verileri ortaya koymak amacıyla rastgele oluşturulan küçük gruplarla odak grup görüşmeleri gerçekleştirilmiştir. Bu bağlamda üç farklı grup oluşturulmuş ve bu gruplarla yarı yapılandırılmış sorular üzerinden odak grup görüşmeleri tamamlanmıştır.

Odak grup görüşmeleri verilerinin analizinin ardından ortaya çıkan temalar; çalışma sürecinin özetleyen yazıların ardından oluşan temalar ile benzerlikler göstermektedir. Araştırmacı tarafından grup üyelerine yönlendirilen sorular da bu temaların oluşmasında belirleyici olmuştur. Araştırma grubu üyelerinin genel olarak vermiş olduğu yanıtlar; "uzman mantosu" uygulaması ve "komisyon model" üst başlıklarını ayrıntılandıracak belirlemeleri içermektedir.

Araştırma sürecine katkı sağlayan grup üyelerinden sadece bir kişi odak grup görüşmesine katılamamıştır. Bununla beraber alan çalışmalarına ilişkin görüşlerini özetlemeyen fakat sürece katkıda bulunan üç grup üyesi de odak grup görüşmesine katılmıştır. Odak grup görüşmesinin ardından oluşan temalar, grup üyelerinin yazmış oldukları özet çalışmaları ile benzerlik gösterdiğinden; araştırmanın o bölümünde yer alan bulgu ve yorumlarda tekrarlar oluşmuştur. Bu bağlamda araştırma verilerinin belirli bir doygunluğa ulaştığı söylenebilir. Bu nedenle odak grup görüşmelerinde sunulan verilere öz bir biçimde yer verilmiştir. 
Araştırma grubu üyeleri ile gerçekleştirilen odak grup görüşmesinde öne çıkan önemli başlıklardan biri uzman mantosu ve komisyon model uygulamalarında üstlenilen rollere ilişkindir. Grup üyeleri kendi yaşantılarından hareketle nerede rol içerisinde oldukları, nerede rolün dışına çıktıklarına ilişkin belirlemelerde bulunmuşlardır. Bu bağlamda araştırma grubu üyelerinin "rol" kavramına yönelik öne çıkan düşünceleri şu biçimdedir :

K16: Uzman mantosunda sadece rolde gibi hissettim ben mesela isimliklerin takılmas1. Orada herkesin birbirine hiç tanımıyormuş gibi, aynı yerde çalışan kişilermiş ciddiyetiyle o ortam oluşturulmuştu gerçekten o zaman bayağı bir rolün içerisinde hissediyordum kendimi...

K12: benim için bu özgürlük rolden daha çok tam böyle her şeyin en güzeli yapabileceğimin en iyisi şeklinde değil de zaten daha önce hayalini kurduğum bir odayı yapmak istemiştim ama bunu yaparken cidden sunum yaparken falan gerçekten o role girmiştim artık rol ile gerçeği ayırt edemiyordum...

K:17: Evet rolde, bir role bürünmedim ben ne diyorsam onu anlattım. Sanki bu işin eri zaten benmişim gibi. Öyleydim, öğrenciydim, öğrenci olarak anlattım. Zaten diyoruz bize böyle bir görev verildi, biz de bunu üstlendik ve hani Kültür ve Sanat Merkezi'nin drama ve dans salonunu tasarlıyoruz. Biz öğrencileriz gibisinden açıklama yapıyoruz anlatmaya başlarken.

K22: Bence rol yaparken bile, bende çok karışıktı aslında hani kendimizken de rol yapıyorduk mesela müzik benim ilgi duyduğum bir alan kesinlikle aslında çok da severim ama sonuçta hiçbirimiz öyle bir şey de bulunmadık, hiçbir zaman da bir müzik odası hazırlamadım o yüzden sanki hayaldi ve sanki uzmanmış gibi davranıyorduk falan bir şekilde kendimizdik ama roldeydik yani uzman olan kendimiz. Gerçekçi bir hayaldi.

Yukarıda yer alan ifadeler uzman mantosu ve komisyon model uygulamalarında grup üyelerinin rol sınırlarına ilişkin değişimler (rol içerisine girmeler ve çıkmalar) yaşadıklarını göstermektedir. Özellikle K22'nin belirtmiş olduğu durum Dorothy Heathcote'un “Alacakaranlık Rol” adını verdiği ve gerçek ile kurgunun birbirine karıştığı durumlara örnek oluşturmaktadır. Katılımcılar özellikle uzman mantosu uygulama süreci içerisinde rol içerisinde oldukları durumlara ve rolde olmayıp kendileri gibi davrandıkları durumlara ilişkin betimlemelerde bulunmuşlardır. Uzman mantosu süreçlerinin düş kurma süreçlerinden beslendiği, etkinlikler yolu ile bu düş kurma durumlarının gerçekçi duygu, düşünce ve tepkileri oluşturduğu görülmektedir. Bu nedenle araştırma grubu üyeleri, rol üstlendikleri anda kendileri gibi olduklarını ve doğal bir davranış sergilediklerini ifade etmişlerdir. Bu ifadelerden hareketle uzman mantosu ve komisyon çalışmalarında yer alan "rol” kavramının gerçek yaşam tepkileri ile benzeştiği görülmektedir.

Araştırma grubu ile gerçekleştirilen odak grup görüşmesi sonrasında ortaya çıkan başlıklardan bir diğeri ise komisyon model uygulamasının sorumluluk üreten bir yaklaşım olduğuna ilişkindir. Araştırma grubu üyeleri; komisyon model uygulaması içerisinde gerçekleştirmiş oldukları etkinliklere ilişkin sorumluluk duyduklarını, bu nedenle Kültür Sanat Merkezi binasının yapımını sahiplendiklerini ifade etmişlerdir. Bununla beraber, sorumluluk üstlenme durumlarının grup üyelerinin kişisel gelişimlerine de katkı sağladığı görülmektedir.

K3: Evet komisyon çalışması çok uzun sürdü ve bizim aslında direkt sorumluluklar almamız gereken bir süreçti. Bana göre bu sorumluluk bilincini ve yaratıcılığı çok yüksek tutan bir şeydi. Benim sorumluluk bilincimden çok kendi sorumluluk bilincimden çok grup arkadaşlarımızın sorumluluk bilinci almaması etkiledi. 
K7: Alana çıktığımız zamanda komisyon çalışması başladığında sorumluluk almamız gerekti, daha bir işin içine girdiğimiz ve daha gerçekçi, büyük bir şey yaptığımızı fark ettik. O biraz bana iyi gelmişti. Büyüdüğümü hissettirdi gibi bir şey. Bir insan sana bir sorumluluk veriyor.

K18: Ama böyle anlatırken anlatırken projeyi çok garip hissediyordum. Komisyon çalışması sorumluluk alma bakımından daha olumlu bir etki biraktı.

K21: Komisyon çalışması gerçekten bize büyük sorumluluklaryükledi, en sorumsuzlarımızdan biri bendim komisyon çalışmasında. Çünkü alana çıkmada gerçekten biz grubumuzdan sıkıntılar yaşıyorduk, bir araya gelemiyorduk, bunlara rağmen gerçekten bize de sorumluluk bilincini aşı1ladı.

Yukarıda yer alan ifadelerden hareketle komisyon model uygulamasının, sorumluluk üretme ve bu sorumluluktan hareketle bilgiye ulaşma isteği uyandırdığg görülmektedir.

Odak grup görüşmelerinde ortaya çıkan bir diğer başlık ise; gerçek yaşam durumlarının, eğitim aracı olmasının, çalışma motivasyonunu genel olarak katılımcıları olumlu etkilediğine ilişkindir. Araştırma sürecinde uzmanlar ve diğer insanlarla gerçekleştirilen temaslar; grup üyelerinin kişisel gelimi ve çalışmaya ilişkin motivasyonlarını olumlu bir biçimde etkilemiştir. Bu başlık altında, grup üyelerinin öne çıkan görüşleri şu biçimdedir:

K4: Bana en iyi gelen kısmı; mimar Özlem Hanım ile gezerken hani kadın bir şaşkındı. Yani onları düşündüğümüze ya da onları yapabildiğimize... Hatta çıkışta da söyledi herhalde. Tam olarak hatırlamıyorum ama siz burada proje hazırlamışsınız. Bu nasıl tanımlanır. Yani şaşkındı, onun belki de üniversite öğrencisi olduğumuz için olabilir. Bu binayı sonuçta biz baştan tasarladık. Bu onun işiydi ve biz bunu yapabildik.

K9: Özellikle günlüklerimde de bahsettiğim Siyasal Bilgiler Fakültesinde görüşmeye gittiğimizde amcanın o kadar yardım etmek istemesi ya da kültür evindeki kişinin bizimle çok ilgilenmesi, bizim fikirlerimizi önemsemesi, bir şeylere katkı sağlamak istemesi belki bana insani değerler anlamında da çok şey kattı.

K14: Ankara Üniversitesi Kültür Şube Müdürü Şükrü Bey ile görüşmek, mimar Özlem Hanım ile görüşmek çok iyiydi benim için. Bu kırılan inancımızı daha çok toparlamaya yardımcı oldu. Belli bir noktasında çalışmayı sahiplendik.

Bu başlık altında, araştırma grubu üyelerinin kendi süreçlerini özetledikleri metinlerde ortaya çıkan verilere koşut verileri betimlediği görülmektedir. Uzmanlar, karar vericiler ve paydaşlarla temas etmenin; çalışmayı sahiplenme ve bir sonraki çalışma adımını belirleme konusunda belirleyici olduğu görülmektedir. Gerçek duyguların, gerçek yaşantıların ve gerçek tepkilerin çalışmaya yönelik sorumluluk ürettiği söylenebilir.

Grup üyelerinin kendi aralarında yaşamış oldukları iletişim sorunları ise motivasyonu azaltan yaşantılar olarak görülmektedir. Çalışmaya ilişkin bireysel olarak sunulan özetleme ve betimleme metinlerinde de sıklıkla karşılaşılan bu durum, var olan sorumluluk paylaşımında ortaya çıkan gerçekçi duygular olarak görülmektedir. Motivasyonlarını olumsuz yönde etkileyen ifadeleri özenli bir biçimde dile getiren grup üyelerinden bazıları; sıklıkla küçük grup çalışmaları ile gerçekleştirilen etkinliklerin daha büyük gruplar halinde gerçekleştirilmesi gerektiğinden söz etmişlerdir.

K3: Bütün eyat, bütün o topluluk burada her akşam geliyorduk mesela ama herkes kendi çalışmasını yapıyordu ya da ne bileyim herkes kendi anketini doldurmaya gidiyordu vesaire 
gibi. Bu biraz daha böyle bizim komisyon çalışmasında verdiğimiz, gösterdiğimiz heyecanı azalttı gibi geliyor bana

K12: Bence komisyon çalışmasının avantaj olarak kazandırdığı bir şey olarak hepimizin söylediği bir şey; grup bilinci aşıladı ama bence bu aslında dezavantaj olarak geldi bizim eyat olarak tümüne bakarsak. Çünkü herkesin belli bir grubu vardı. İlk baştaki grupları uzman mantosunda farklıydı, komisyon çalışmasında farklılaştı. Yine arada gidiş gelişler oldu ve alana çıkarken herkes sadece kendi grubu ile çıktı, kendi grubu ile anlaşamayan insanlar da oldu.

Araştırma grubunun tercih ettiği veri toplama araçlarının başında kendi geliştirdikleri anketler yer almaktadır. Alan çalışmalarında grup üyelerinin anket uygulamasını tercih etmelerinin gerekçeleri arasında ortak sorularla hareket etme isteğinin yer aldığ 1 görülmektedir. Aynı küçük grup içerisinde yer alan farklı üyeler; alan çalışmalarında kimi zaman birbirlerinden ayrı biçimde hareket etmiş̧lerdir. Grup üyeleri, oluşan bu ayrıksılı̆̆ı olabildiğince aynı soruları sorarak gidermeye çalışmışlardır. Bu veri toplama biçiminin tercih edilmesi ile grup üyelerinin anket uygulamaya ilişkin kaygılarını azaltmaya çalıştıkları düşünülmektedir.

Grup üyeleri ile gerçekleştirilen odak grup görüşmeleri, onların alan çalışmalarına ilişkin görüş ve yaşantılarını ortaya koymuştur. Odak grup görüşmesine katılan grup üyeleri birbirlerine yaşantıları ile ilgili durumlara yönelik anımsatmalarda bulunarak çeşitli konu başlıklarına ilişkin veri paylaşılmasına olanak sağlamışlardır. Özet çalışmalarında ayrıntılandırılan bir çok tema, odak grup görüşmelerinin ardından da ortaya çıkmıştır. Benzeşen bu temalardan hareketle, odak grup görüşmelerinin diğer veri toplama araçları ile toplanan verileri desteklediği söylenebilir. Veri çeşitlemesi yapılarak daha güvenilir bir sonuca ulaşılmış ve grup üyelerinin komisyon modele ilişkin düşünceleri ayrıntılandırılmıştır. Odak grup görüşmesi verilerinin analizinin ardından çalışmaya ilişkin tüm verilerin bulgu ve yorumları sonlandırılmıştır.

\section{Tartışma, Sonuç ve Öneriler}

Araştırmanın bu aşamasında, doğal bir biçimde akan yaşamı değiştirmeden, sosyal etkileşim yolu ile duyuşsal ve bilişsel kazanımlara ulaşılmaya çalışılmıştır. Komisyon model uygulaması boyunca devam eden etkinlikler bir sahneleme süreci gibi düşünüldüğünde, her grup üyesi bütün bir performansın belirli küçük performatif oyuncuları olmuşlardır. Bu bağlamda uygulama süreci; grup üyelerinin eylemde bulundukları anlar, oluşan etkileşimler, yaşanılan kaygılar, tercih edilen yöntemler gibi birçok durum üzerinden sorgulanacak ortamları içermektedir. Doğal bir ortam içerisinde, kendi seçim ve tepkileri ile komisyon model uygulaması etkinliklerine yön veren grup üyeleri; sosyal etkileşimlerde bulundukları için değişken sayılabilecek duygu durumları ve kazanımlara tanık olmuşlardır.

Bulundukları sosyal yapı içerisinde birbirleri ve alanda yer alan insanlar ile etki ve tepki alışverişinde bulunan araştırma grubu üyeleri, doğal sayılabilecek bir biçimde araştırma sürecine dahil olmuşlardır.

Alışılagelmiş eğitim ortamları, öğrencilerin belirli hareketler, tavır ve tepkiler sergiledikleri, belirli kurallar ile çerçevelenmiş bir set oluşturmaktadır. Bununla beraber öğrenci grubunun kendini daha rahat hissettiği ortamlar katı kurallar ile çerçevelenmediğinden daha gerçekçi ve doğal 
etkileşimleri içermektedir. Sözgelimi bu çalışma özelinde, alan çalı̧̧malarına çıkan grup üyeleri kendilerini daha rahat hissettikleri ortamlardan veri toplamaya çalışmışlardır. Bu ortamlarda grup üyeleri, istedikleri ve hazır hissettikleri zamanlarda diğer paydaşlar ile etkileşimde bulunmuşlar, istedikleri zamanda da etkinliği sonlandırmışlardır. Sosyal statü olarak; deneyim, cinsiyet, fakülte bölümü vb. noktalardan farklı seviyede bulunan grup üyeleri, kendi aralarında herhangi bir biçimde yaptırım oluşturacak kurallar belirlememişlerdir. Bireysel farklılıklar, çalışmaya ilişkin motivasyonu ve grup üyelerinin duygu durumlarını etkilemiştir. Araştırmacı, komisyon model uygulaması süresince olabildiğince "öğretmen" sözcüğünün kendiliğinden getirdiği hiyerarşik yapıyı hissettirmemek adına rehber görevi üstlenip, doğrudan karar verme süreçlerini grup üyelerine bırakmıştır. Buna rağmen; grup üyeleri ve araştırmacı arasında oluşan önceki kodların hiyerarşik düşünceden yeterince sıyrılamadığı gözlemlenmiştir.

Komisyon model uygulaması rol ve gerçeklik kavramlarının karıştığı bir uygulama sürecini içermektedir. Çalışma sürecinde grup üyeleri, küçük gruplar halinde çalışmalar yürüterek, bireysel gelişim süreçleri göstermişlerdir. Çalışma kapsamında komisyon model uygulaması içerisinde gerçekleştirilen grup çalışmalarının genellikle olumlu bir motivasyon ürettiği sonucuna varılmıştır. Bununla beraber görev odaklı çalışmalarda yeterince sorumluluk üstlenmeyen öğrencilerin ise diğer grup üyelerinin motivasyonunu olumsuz etkilediği görülmüştür. Dramaturjik yaklaşım ile dünyanın bir sahne olduğunu söyleyen Erving Goffmann'ın, “takım” adını verdiği etkileşimli yaratımlar ve bu yaratımlarda bireylerin vermiş olduğu tepkilere ilişkin görüşleri şu biçimdedir:

Aynı takımın üyeleri olan bu bireylerin sırf takımdaşlık nedeniyle birbirleriyle önemli bir ilişki içinde olacakları açıktır. Bu ilişkinin iki temel bileşeninden söz edebiliriz. Birinci olarak, öyle görünüyor ki takım performansı bir yandan devam ederken, takımın herhangi bir üyesi gösterinin foyasını meydana çıkarma ya da uygunsuz davranışlarla performansı azaltma gücüne sahiptir. Tüm takım arkadaşları birbirlerinin hareket ve davranışlarına güvenmek zorundadırlar. Buna göre, takım arkadaşlarını birbirlerine bağlayan karşılıklı bir bağımlı1ık söz konusudur (Goffmann, 2009).

Komisyon model uygulaması süresince grup üyelerini birbirlerine bağlayan bağımlılık; yapılacak olan Kültür Sanat Merkezinin sahiplenilmesi, üretilen sorumluluk, uzmanlarla görüşülmesi ve yapılan işin ciddiyetinin kavranması gibi başlıklar yolu ile daha belirgin bir hal almıştır. Belirginleşen bu bağlayıcı duygunun, etkileşime girilen kişilerin tavır ve düşünceleri ile geliştiği söylenebilir. Takımın bir parçası olan grup üyeleri; etkileşime girdikleri kişilerden edindikleri bilgi, tepki ve düşüncelerle kendi performanslarını dönüştürmüşlerdir. Kimi grup üyeleri gerçek yaşamda yer alan ve paydaş olarak tanımlanan insanlara temas ettiği için çalışma adımlarını atmak adına iştahlanmış, kimileri ise grup arkadaşları kadar iştahlı çalışmadıkları için kendilerini sorumlu tutmuşlardır. Bu durumları oluşturan motivasyonların onlarca gerekçesi olabilir. Bütünlüklü bir yapının ayrı parçaları olarak katılımcıların yaşadıkları süreç, bireysel bir biçimde incelendiğinde; her grup üyesinin ayrı ayrı çerçeve ile sunduğu performanslarının oluşturduğu setlere ve vitrinlere bakmak gerekmektedir. Bu bağlamda grup üyelerinin iç disiplini komisyon model uygulaması için önem kazanmaktadır.

Komisyon model uygulamalarının toplum gelişimi ile de ilgili olduğu söylenebilir. Komisyon model uygulaması odağına alınan ve ortak görevlerle sonuca ulaştırılmaya çalıştırılan çalışmalar toplumda yer alan diğer paydaşların da fikirleri alınarak sonuca ulaştırılmaya çalışılmaktadır. Bu bağlamda Dorothy Heathcote'un önemsediği dramanın toplum ile ilgili olması gerekliliği 
karşılanmaktadır. Dorothy Heathcote, drama çalışmalarının toplumsal boyutu ve sanatsal boyutuna yönelik olması gerekliliğini eleştirel bir çerçeveden ele almıştır. Bu konuda kendi yaklaşımlarının da gelişme gerekçesini sunan Dorothy Heathcote așağıda yer alan ifadeleri kullanmaktadır:

“Tüm öğretim yaşamım boyunca özgünlük meselesi ile ilgili olduğunu düşündügüm iki şeye ilişkin uğraş verdim. Birincisi bir "drama öğretmeni” olarak tanımlanırken ve bu kadar açık bir biçimde işlev sağlarken insanların drama çalışmalarını sadece oyun, kurgu ve rol ile ilgili olarak algılaması beni rahatsız ediyor. Dramanın bunlarla da ilgisi var ama drama toplum için daha fazla potansiyele sahip. İkincisi ise pek çok insanın eğitim durumlarında dramanın kullanımını, ayrı bir konu olarak ya da "özel” bir mesele olarak görmesidir. Bu durumlar ile uğraşmak drama çalışmalarında sanat biçimlerini ihmal etmeme yol açmıştı. Diyagram haritaları, eskizler, fotoğraflar vb. gibi diğer üretkenlik betimlemeleri ile ilişkili bir biçimde tartışmam gerektiğini böylece farketmiş oldum"(Heathcote,1985).

Bu söylemlerden hareketle Dorothy Heathcote yaklaşımlarının bir arayış içerisinde olduğu görülmektedir. Drama çalışmalarına ilişkin oluşan ve tartışılması gereken yargıları dikkate alan Heathcote'un bu söylemleri, uzman mantosu yaklaşımının temellerini oluşturmaktadır. Drama çalışmalarında "üretkenlik betimlemeleri" olarak tanımlanan çalışmalarını önemseyen Heathcote, uzman mantosu çalışmalarında bu eksikliği giderebilecek önemlemler sunmuştur. Ardından da dramanın toplumsal boyutunu daha da ön plana çıkartan ve gerçek yaşam durumları içerisinden olabildiğince çok insana temas eden bir yaklaşım olan "Komisyon Model” uygulamasını geliştirmiştir. Araştırmanın bulgu ve yorumları dikkate alındığında komisyon model uygulamasının toplumsal boyutu önemseyen bir yaklaşım olduğun görülmektedir.

Araştırma bulgularından hareketle komisyon model yaklaşımının sorumluluk üreten, sosyal etkileşimin yoğun olduğu, gerçek yaşamda belirli rollerle gerçekleşen, doğal, öğretmenlik baskısını oluşturmayan, sanat formlarını kullanan, grup çalışmalarını sistematik bir hale getiren ve eylem adımlarının sonuçlarından hareketle yeni eylem adımları üreten bir yaklaşım olduğu sonucuna varılmıştır.

Çalışma sonunda alan uzmanlarına ve araştırmacılara yönelik şu önerilerde bulunulabilir:

- Komisyon model uygulamalarının alan yazında yeterince yer almaması nedeniyle "komisyon model” yaklaşımını tanıtmaya ve tartışmaya yönelik çalışmalar yapılabilir.

- Komisyon model yaklaşımının drama alanındaki kabul sorunu nedeniyle kurgu ve gerçeklik ilişkisinin derinlikli bir biçimde tartışılması ve bu başlık altında sosyolog, psikolog, sanatçı ve eğitimcileri bir araya getirebilecek etkinlikler düzenlenebilir.

- Drama çalışmaları daha çok sosyal etkileşimi ve toplumsal değişimi önemseyen bir biçimde yapılandırılılmalıdır.

- Drama çalışmaları gerçek yaşama temas eden boyutları arttırılmalıdır.

- Komisyon model uygulamalarının az olması nedeniyle yeni istemciler bulunarak komisyon model uygulamalarının arttırılması önerilmektedir. 


\section{Kaynakça}

Bayad, A. (2016). Erving Goffman'ın benlik kavramı ve insan doğası varsayımı. Psikoloji Çalışmaları Dergisi. 36(1), 65-80.

Creswell, J. W. (2013). Nitel araştırma yöntemleri beş yaklaşıma göre nitel araştırma ve araştırma deseni. Ankara: Siyasal Kitabevi.

Dewey, J. (1996). Democracy and education. (Çev. Otaran, M.S.) Ankara: Başarı Kültür Yayınları Dizisi

Ekiz, D. (2009). Bilimsel araştırma yöntemleri. Ankara: Anı Yayıncılık.

Eriksson, S. A. (2009). Distancing at close range. ABO Akademi.

Fiala, O. (1977). "An artistic affinity. Notes on Dorothy Heathcote's and Bertolt Brecht's modes of work". National Association of Drama in Education Journal. 2(1), 29-32.

Goffman, E. (2009). Günlük yaşamda benliğin sunumu. İstanbul: Metis Yayınları.

Heathcote, D. (1985). Improvisation. In Dorothy Heathcote: Collected writings on education and drama, (ed. Liz Johnson and Cecily O'Neill), 44_8. London: Hutchinson.

Hesten, S. (1993). The Dorothy Heathcote Archive (Doctoral Dissertation). Manchester, Metropolitan University.

Kuzu, A. (2005). Oluşturmacılı̆̆a dayalı çevirimiçi destekli öğretim: Bir eylem araştırması (Yayımlanmamış Doktora Tezi). Eskişehir Anadolu Üniversitesi, Eskişehir.

Metinnam, İ., Adıgüzel, Ö. (2016). "Bireyin bireyselliği” odağında Brian Way’in drama anlayışının incelenmesi. Yaratıcı Drama Dergisi. 11(2), 1-28.

Schön, D. A. (1983) The reflective practitioner: how professionals think in action. San Francisco: Ca, Jossey-Bass.

Tor, H. A. (2008). A comparative analysis of the relationship between dramaturgy and epistemology in the praxis of Gavin Bolton and Dorothy Heathcote. Research in Drama Education:The Journal of Applied Theatre and Performance. 13(3), 321-335.

Özen, Z. (2011). Dorothy Heathcote'un yaratıcı drama yaklaşımları (Yayımlanmamış Yüksek Lisans Tezi). Ankara Üniversitesi, Ankara.

Yıldırım, A., Şimşek, H. (2013). Sosyal bilimlerde nitel araştırma yöntemleri (9. Baskl). Ankara: Seçkin Yayınları. 


\begin{tabular}{rr} 
çağdaş & Yaratıcı Drama Dergisi 2018, 13(2), 173-188 \\
drama & www.yader.org \\
\hline
\end{tabular}

\section{Leonardo Da Vinci'nin “Son Akşam Yemeği” Adlı Eserinin Yaratıcı Drama Yöntemiyle Çözümlenmesinde Öğrenci Görüşlerinin Belirlenmesi}

\begin{tabular}{|c|c|}
\hline \multicolumn{2}{|r|}{$\begin{array}{l}\text { Abdulgafar Terzi }{ }^{1} \\
\text { Nami Eren Beştepe }{ }^{2}\end{array}$} \\
\hline Makale Bilgisi & $\ddot{O} z$ \\
\hline DOI: $10.21612 /$ yader.2018.013 & $\begin{array}{l}\text { Drama ve sanat ĕgitimi ilişkisi son yıllarda artmaya başlamıştır. Dramanın sanat } \\
\text { alanını ve sanat eğitimini olumlu etkileyebileceği düşünlmektedir. Özellikle son }\end{array}$ \\
\hline Makale Geçmişi & yıllarda okullarda dramanın sanat eğitiminde yöntem olarak kullanılması, sanatı \\
\hline Geliş tarihi & $\begin{array}{l}\text { dolayısıyla da sanat eğitimini ögrenciler tarafindan daha eğitici ve ögretici hale } \\
\text { getirmiștir. Bu çalıșmada 15. yüzyllın sonlarında (1495-1498) Leonardo Da Vinci'nin }\end{array}$ \\
\hline 05.07 .2018 & $\begin{array}{l}\text { "Son Akşam Yemeği" adlı tablosu temel alınmış olup, öğrencilerin yaratıcı drama } \\
\text { yöntemiyle bir eseri çözümleme ve alımlamalarına ilişkin görüş̧leri belirlenmeye } \\
\text { çalışılmıştır. Bu noktadan hareketle çalışmanın genel amacı, öğrencilerin Leonardo } \\
\text { Da Vinci'nin "Son Akşam Yemeği" adl eserini yaratıcı drama yöntemiyle }\end{array}$ \\
\hline Anahtar Sözcükler & çözümlemelerini ve alımlamalarını sağlamaktır. Çalışma grubu, MEB'e bağlı \\
\hline & $\begin{array}{l}\text { bir devlet okulunun 6. ve 7. sinıf ögrencilerinden } 11 \text { ve } 13 \text { yaş aralığında, daha } \\
\text { önce drama yaşantısı olmayan } 14 \mathrm{klz}, 2 \text { erkek ögrenci olmak üzere toplam } 16\end{array}$ \\
\hline Sanat & ögrenciden oluşmuştur. Araştırmada nitel araştırma yönteminden yararlanılmış, \\
\hline Sanat eseri & $\begin{array}{l}\text { odak grup görüşmesiyle veriler toplanmış ve elde edilen verilerin betimsel analizi } \\
\text { yapılmıştır. Drama yöntemiyle işlenen sürecin sonucunda ögrencilerin eleştirel }\end{array}$ \\
\hline Sanat eğitimi & anlamda daha fazla pratik yapmalarına olanak sağlandiğl, ögrencilerin bir resme \\
\hline Leonardo Da Vinci & $\begin{array}{l}\text { nasıl bakılacağını, resmin biçim içerik özelliklerini ve sanatsal düzenleme ögelerini } \\
\text { kavradıkları görülmüştür. }\end{array}$ \\
\hline \multicolumn{2}{|c|}{$\begin{array}{l}\text { Determining of Students' Views Regarding the Analysis of } \\
\text { "Last Supper" by Leonardo Da Vinci Through Creative Drama }\end{array}$} \\
\hline Article Info & Abstract \\
\hline DOI: $10.21612 /$ yader.2018.013 & $\begin{array}{l}\text { The relationship between drama and art education has begun to increase in recent } \\
\text { years. It is conjectured that the drama might positively influence the art field and }\end{array}$ \\
\hline Article History & $\begin{array}{l}\text { art education. Especially in recent years, the use of drama as a method in art } \\
\text { education in schools has made art education more educational for students. This }\end{array}$ \\
\hline 18.06.2018 & study was based on the "Last Supper" by Leonardo Da Vinci at the end of the 15th \\
\hline Accepted & $\begin{array}{l}\text { century (1495-1498) and attempted to identify the views of the students resting on } \\
\text { the analysis and reception of the work through creative drama. The general aim } \\
\text { of this study is to help students analyze and receive the work "Last Supper" by } \\
\text { Leonardo Da Vinci's through the creative drama. The study group consisted of } 16\end{array}$ \\
\hline Keywords & $\begin{array}{l}\text { students, } 14 \text { females and } 2 \text { males, who neverhad drama experience previously, aged } \\
\text { between } 11 \text { and } 13 \text { years of 6th and } 7 \text { th grade students of a state school affiliated }\end{array}$ \\
\hline Drama & to Turkish Ministry of Education. Qualitative research method was used in the \\
\hline Art & $\begin{array}{l}\text { research, and data were gathered via focus group interview, and descriptive analysis } \\
\text { of the obtained data was done. As a result of the process through drama method, it }\end{array}$ \\
\hline Artistic work & was found that students were allowed to fulfill more practice through critical lens, \\
\hline Art education & $\begin{array}{l}\text { learned how to look at and interpret a painting, and comprehended the features of } \\
\text { form and content and artistic regulation elements. }\end{array}$ \\
\hline Leonar & \\
\hline
\end{tabular}

Öğretmen, MEB, E-posta: terzigaffar@gmail.com

2 Dr. Öğretim Üyesi, Hatay Mustafa Kemal Üniversitesi, E-posta: nbestepe@gmail.com. 


\section{Giriş}

İnsanoğlu geçmişten günümüze kadar sanatla iç içe olmuştur. Bu süreçte sanat, yaşamın vazgeçilmez bir unsuru ve kişilerin eylemlerinin de önemli bir parçası durumuna gelmiştir. Yaşamın sanatla birleştiği bu tür durumlarda insan hep bir arayış içerisine girmiş, sanatın gücünü daima kullanmaya devam etmiştir. Botton (2007, s.116), "Mağara duvarlarına resim yapanlar ve bu resimlerle karşılaşanlar yok olup gittikten sonra bile yapılan bu resimler hâlâ bizlere çok şeyler anlatabiliyor. Öyle ki karşılaştığımız güzel bir nesne her yönüyle bizi etkisi altına alabiliyor ve onun hakkında değer yargılarına varabiliyoruz". Botton sanatın uzun süreli etkisinden söz ederken; Read (2014, s.32) sanatın güçlü etkisinden söz ederek şu ifadeleri dile getirmiştir; "Bence sanatın öyle etki yapıcı bir özelliği vardır ki... Bu özellik sadece parçalar arasında bir bağlantı ve düzen görme değildir; her parça, bütünü gibi bir çeşit duygululukla dolar. Bizim saf güzellik tanımımıza göre bu duygu hayatta yaşanmış heyecanların hatırlanmasından veya sezilmesinden doğmaz; buna rağmen bunun bazı derin, belirsiz ve çok genelleşmiş hatıralardan kuvvet aldığını da bazen düşünürüm”. Botton ve Read sanatın güçlü etkisinin ancak yaşamla sanatın birlikte harmanladığında daha derin anlamlarnın olduğunu dile getirmişlerdir. Sanatın yaşamımıza kattığı anlam arayışları günümüzde her yönden daha etkin kullanılmaya başlamıştır. Sanat aracılığıyla yapılan tüm bu yararlar bize sanatın estetiksel anlamda bir değerlendirmeye tabi tutulacağını da göstermiştir. Sanat, biçemini göz önünde tutup zevk amaçlı eserler oluştururken sanatın insana özgü özelikler de taşıdığını görürüz. Taşıdığı bu özellikler göz önünde bulundurulduğunda sanat kavramı, sanat eseri aracılığıyla daha da anlamlı olmaya başlamıştır. Fakat sanat eğitiminin günümüz eğitim sisteminde ne kadar yer aldığı, sanattan ve sanat eserlerinden öğrencilerin ne derece beslendiği hep tartışma konusu olmuştur. Kant (Akt.Tanilli, 1999, s.447) eğitimdeki soruna şu açıdan bakar: "İnsanoğlunun güçleri arasında sayabileceğimiz iki buluşu vardır ki, bunlar da insanları yönetme sanatı ile onları eğitme sanatıdır". Kant'ın güç olarak gördüğüne sanat eğitimi açısından bakan Özer (2000, s.35) görüşlerini “Sanat görüşü, anlayışı ve yorumlayışı bakımından hızlı ve yoğun bir eğitime ihtiyaç olan ülkemizde, sanatı öğreten, uygulatan ve de yayan kurumların her türlü geçerlilikten yoksun klişeleri toplumun zihninden silip atması kaçınılmaz bir görevdir.” şeklinde ifade etmiştir.

Yolcu (2009, s.93) “Sanat eğitimi; kişiye estetik yargı yapabilme konusunda yardımcı olmayı amaçlarken, yeni biçimleri hissedip, heyecanlarını doğru biçimlerde yönlendirmeyi öğretir. Demek ki sanat eğitimi, sanatçı yetiştirmeye değil, yetiştirmek durumunda olduğu her kişiyi yaratıcılığa yöneltip, onun bilişsel, duyuşsal ve duygusal eğitim ihtiyaçlarını karşılamaya yöneliktir” şeklinde ifade eder.

Aykut ise (2011, s.94) düşüncelerini "Sanat eğitiminin yalnız insana özgü bir gereksinim olduğu varsayımından hareket edersek, bireyin tüm ruhsal ve bedensel eğitimi, bütünlüğü içinde estetik duyguları geliştirilmesi, yetenek ve yaratıcılık gücünün olgunlaştırılması çabası sanat eğitiminin anlamına açık bir görüntü kazandırır.” şeklinde ifade etmiştir. Aykut sanat eğitiminin yalnız insana özgü gereksinimlerinden bahsederken, San (1979, s.3) "Şu da iyice belirtilmelidir ki sanat eğitiminin amacı sanat için eğitim, yani belli uğraşısı olan bir sanatçı yetiştirmek değildir. Amaç sanatla eğitimdir; gerek sanat uğraşında bulunan kişide, gerek sanat eseri ile karşılaşıp onu değerlendirende harekete geçen tüm zihinsel yeti ve süreçleri, duyu, duyum, algılama, imgeleme, düşünme, anma, çağrışım gibi güçleri eğitmektir. Sanatı algılamaya hazır ve sanatı seven, hem eskinin, hem çağının sanat görüngülerini (phenomenon) algılayıp değerlendirebilecek kişiler yetiştirmektir”. 
Beştepe (2006, s.8) ise bu konudaki görüşlerini “Günümüzde sanatsal yaratım sonucunda sanat yapıtlarının ortaya konması kadar bu yapıtların açıklanmasına, anlaşılmasının sağlanmasına ve değerlendirilmesine de gereksinim duyulduğundan söz edilebilir. Bir yapıtın açıklanmasının ve değerlendirilmesinin, o yapıtın tanıtılmasına ve anlaşılmasına etkisi olabileceği gibi sanat kuramlarının, estetik kuramlarının ve sonuçta sanatın gelişimine de katkı sağlayacağı düşünülebilir.” şeklinde ifade etmiştir. Dolayısıyla okullardaki görsel sanatlar dersinde ve diğer derslerde bir sanat eseriyle karşılaşan öğrencilere sadece soruların sorulup cevapların alındığı bir öğretim yöntemi uygulanmamalıdır. Bu tür öğretim yöntemlerinin kullanılması öğrenciyi sınıf içerisinde pasifleştirip, sanat eserinden elde edilen bilgilerin de yaşamla ilişkisinin kurulmasını engellemiş olur. Öğrencilerin sınıf içerisinde pasifliğini daha da artıran bu tür yöntemler, sanat eserlerinden edinilen bilgilerin amacına uygun kullanılmamasına da neden olur. Okullarımızda geleneksel öğretim yöntemleriyle öğrencilere verilen sanat eleştirisi öğretimi, sanat eserleri hakkında kuru bilgilerin ezberlenmesinden öteye geçmemektedir. İlter (2014, s.564) bu düşünceye uygun olarak görüşlerini şöyle ifade eder; “Geleneksel öğretim yöntemleri ve düz anlatım yönteminin kullanıldığı bir derste öğrenci etkileşimi olmamakta ve anlatım tek yönlü iletişime dayalı öğretmen merkezli yöntem olarak ortaya çıkmaktadır. Nitekim doğrudan anlatım yönteminde iletişim ve etkileşimden çok iletim yani doğrudan aktarım söz konusu olmaktadır. Çünkü bu yöntem, öğretmenin sunuş yoluyla öğrencilerine doğrudan bilgi ve beceriler kazandırdığı, dolayısıyla öğrencilerin öğrenme sürecinin merkezinde olmadığı bir yöntemdir. Öğrenci, verilen bilgileri pasif olarak dinlediğinden herhangi bir etkileşimde bulunamaz". Tanımdan da anlaşılacağı üzere geleneksel yöntemlerle işlenen derslerde öğrenci yalnızca bilgileri alan yani pasif dinleyici durumunda kalmaktadır. Fakat öğrenci doğası gereği harekete ve oyuna düşkündür. Bu açıdan bakıldığında sanat eleştirisi öğretiminde hareketin ve oyununun ön planda olduğu bir öğretim yöntemine ihtiyaç duyulmaktadır. Dolayısıyla da sanat eserlerini çözümleme ve alımlama noktasında etkili ve doğru yöntemlerin kullanılması gerekli bir unsur olarak karşımıza çıkar. Bu açıdan baktığımızda yaratıcı drama yöntemi, sanat eserlerini anlama ve anlamlandırma sürecinde öğrencilerin sanat eserleri üzerinden düşünmeleri, sorgulama yapmaları ve yaratıcı bir süreci yaşamaları açısından önemlidir. Yaratıcı drama yöntemiyle öğrencinin düşünme ve sorgulamayla başlayan yaratıcı serüveni yine bu yöntemde kullanılan tekniklerle öğrencide sanat eğitiminin kazanımlarını daha da kalıcı hale getirir. Ayrıca sanat ve yaratıcı drama gibi disiplinlerin bir araya gelmesi sanat eğitimi alanına farklı bir yaklaşım getirmesi bakımından da önemli görülmüştür.

Sağlam (2006, s.57)’a göre ‘Öğrencinin kendini en çok bulduğu ve enerjisini kullandığı ortam oyun ortamıdır. $\mathrm{Bu}$ ortamda gerçekleşen her şey öğrencilerin yapacağı çalışmayı benimsemesini, kendi isteğiyle yapmasını sağlar. Dolayısıyla sanat eğitimi ancak kişinin özgürce oynayabileceği oyun ortamında olabilir." Oyun oynama ve canlandırmaların etkin rol oynadığı yaratıcı dramayı bilgi edinmede yararlı bir araç olarak gören Sağlam, Bolton'un sözlerini "Drama dersi hem eğitimin hem de sanatın isteklerini karşılayacak biçimde yapılandırıldığında öğrenme/öğretme deneyimi daha etkin olacaktır." şekilde aktarır. Sanat ve sanat eserinden yola çıkılarak gerçekleştirilen tüm süreçler de bize drama ve sanatın ne kadar iç içe olduğunu gösterir.

İlhan (2007, s.140) "Yaratıcılığın gelişmesinde bilindiği gibi sanat eğitiminin önemli bir yeri vardır. Yaratıcı drama eğitimi de aynı zamanda bir sanat eğitimidir. Yaratıcı drama tüm sanat alanları ile iç içedir. Yaratıcı drama ile ilgilenen biri sanat olaylarını, sanat kuramlarını, sanat akımlarını, sanat eleştirilerini takip etmeli; tiyatro, bale, konser, sergi vb. etkinliklere katılmalı, bunları izlemeli en azından bunlardan haberdar olmalıdır". Yukarıdaki açıklamalar yaratıcı dramanın tüm duyu 
organlarımızı kullanarak diğer sanatlarla olan bağı güçlendirdiğini göstemektedir. Vural \& Somers (2011, s.81), "Eğitimde yaratıcı drama yolu ile pek çok içerik birimini öğretmeye yönelik öğrenmeöğretme çerçevesi hazırlanırken, resim, müzik, fotoğraf, heykel gibi sanat alanlarına ilişkin ürünler de birer araç olarak kullanılmaktadır." şeklinde ifade eder. Yaratıcı dramanın görmeyi sağlayan en önemli araç olduğunu söyleyen Adıgüzel ise (2002, s.336) düşüncelerini "Yaratıcı drama geniş anlamda bir görme eğitimi, görmeyi öğreten bir süreçtir. Görmenin buradaki anlamı düşünmeyle bütünleşmektedir. Göz duyarlılığ gelişmiş, görmeyi öğrenmiş, gördüklerini düşünmeyle birleştirmiş olan, müzik dinlerken, öykü okurken, şiir dinlerken de o sanat yapıtının iletisini "görerek" onu daha kolay anlayacaktır." şeklinde ifade etmiştir. Genel anlamda yaratıcı dramanın kendi iç dinamiklerinin sanatın iç dinamikleriyle ne kadar örtüştüğünü, başta sanat eleştirisi olmak üzere ve bunu takip eden tüm sanat dallarını da içine alan bir disiplin özelliği taşıdığını görmekteyiz.

\section{Araştırmanın Amacı}

Araştırmanın genel amacı, araştırmaya katılan öğrencilerin Leonardo Da Vinci'nin “ Son Akşam Yemeği” adlı eserini yaratıcı drama yöntemiyle çözümleyerek alımlamalarını sağlamak ve bu konuya ilişkin görüşlerini belirlemektir. Bu genel amaçtan hareketle öğrencilerin;

1. Bir sanat eserine nasıl bakılacağına ilişkin görüşleri,

2. Sanat eseri incelemesinde yaratıcı dramanın yöntem olarak kullanılmasına ilişkin görüşleri,

3. Leonardo'nun Son Akşam Yemeği tablosundaki biçim ve içeriğin (kişiler, yemek, mekân) anlaşılıp, anlaşılmadığına ilişkin görüşleri,

4. Bir sanat eserinde sanatsal düzenleme ögelerinin ( çizgi, şekil, 1şık- gölge, doku, renk, biçim, değer, ton, mekân v.b ) anlaşılıp, anlaşılmadığına ilişkin görüşleri,

5. Yaratıcı dramaya ilişkin görüşleri, belirlenmeye çalışılmıştır.

\section{Yöntem}

\section{Araştırmanın Modeli}

Öğrencilerin, Leonardo Da Vinci'nin “Son Akşam Yemeği” adlı eserinin yaratıcı drama yöntemiyle çözümlemeleri ve alımlamaları amaçlanan araştırma, nitel araştırma yöntemine dayalı bir araştırmadır. Nitel araştırma; gözlem, görüşme ve doküman analizi gibi nitel veri toplama yöntemlerinin kullanıldığı, algıların ve olayların doğal ortamda gerçekçi ve bütüncül bir biçimde ortaya konmasına yönelik nitel bir sürecin izlendiği araştırmadır (Yıldırım ve Şimşek, s.2006).

Leonardo Da Vinci’nin “Son Akşam Yemeği” adlı eserinin seçilmesinin nedeni, sanat tarihi açısından resim sanatının özelliklerini taşıması, resmin öğreticiliğinin ön planda tutulması, dramatik yapısının ve anlamının güçlü olmasıdır. Ayrıca eser içinde somut nesnelerin bulunması, eserin güçlü bir hikâyesinin olması, tarihsel ve estetik bir değer taşıması ve tablo içerisinde üçlü figürlerin birbirleriyle dramatik ilişkisi de bu resmin seçilmesinde önemli noktalardır. 


\section{Çalışma Grubu}

Çalışma grubu, MEB'e bağlı bir devlet okulunun 6. ve 7. sınıf öğrencilerinden 11 ve 13 yaş aralığında, daha önce yaratıcı drama yaşantısı olmayan 14 kız, 2 erkek öğrenci olmak üzere toplam 16 öğrenciden oluşmuştur.

\section{Verilerin Toplanması ve Analizi}

Araştırma kapsamında ulaşılan veriler odak grup görüşmesi aracılığıyla elde edilmiştir. Odak grup görüşmesi "1lımlı ve tehditkar olmayan bir ortamda önceden belirlenmiş bir konu hakkında algıları elde etmek amacıyla dikkatle planlanmış bir tartışmalar serisi”" olarak tanımlanabilir (Yıldırım ve Şimşek, 2006). Araştırmanın amacı doğrultusunda beş tane açık uçlu sorudan oluşan bir görüşme formu hazırlanmıştır. Bu formun geliştirilmesinde alan yazında yer alan örnek formlar dikkate alınarak maddeler yazılmış ve bu maddeler 4 uzman tarafından incelenmiştir. Uzmanların önerileri dikkate alınarak görüşme formunda gerekli düzenlemeler yapılmış ve forma son hali verilmiştir. Formda yer alan beş soru şöyledir: 1. Bu çalışmadan önce bir sanat eserine nasıl bakardınız, şimdi nasıl bakıyorsunuz? 2. Sanat eseri incelenmesinde yaratıcı dramanın yöntem olarak kullanılmasına ilişkin neler düşünüyorsunuz? 3. Leonardo'nun Son Akşam Yemeği tablosunun biçim ve içerik özelliklerine (kişiler, yemek, mekân) ilişkin neler söyleyebilirsiniz? 4. Leonardo'nun Son Akşam Yemeği tablosunda sanatsal düzenleme ögelerini ( çizgi, şekil, 1şık- gölge, doku, renk, biçim, değer, ton, mekân vb.) görebildiniz mi? 5. Yaratıcı drama çalışmasını nasıl buldunuz, yaratıcı dramayla ilgili görüşleriniz nelerdir? Bu beş soru, son oturumun bitiminden sonra gruba yöneltilmiş ve elde edilen veriler bilgisayar ortamına aktarılarak derlenmiş, araştırma soruları ile ilişkilendirilerek analiz edilmiş ve kayıt altına alınmıştır.

Araştırmada elde edilen verilerin çözümlenmesinde betimsel analiz tekniği kullanılmıştır. Betimsel analizde elde edilen veriler daha önceden belirlenen temalara göre özetlenir ve yorumlanır (Yıldırım ve Şimşek, 2006). Odak grup görüşmesiyle elde edilen öğrenci görüşleri "Sanat Eseri, Yaratıcı Drama Aracılığıyla Sanat Eseri İnceleme, Sanat Eserinde Biçim ve İçerik, Yaratıcı Drama, Sanatsal Düzenleme Ögeleri” alt başlıkları altında yorumlanmıştır.

Araştırmada elde edilen bulgularda, araştırmanın güvenirliğini desteklemek amacıyla öğrencilerin yanıtlarından aynen alıntılar yapılmıştır. Doğrudan alıntılarda öğrencilerin sözleri (Ö, numara) şeklinde gösterilmiştir. Ayrıca, yine araştırmanın güvenirliğini desteklemek amacıyla çocukların ve velilerinin izni ile atölye çalışmaları kamera ve fotoğraf çekimleriyle kayıt altına alınmıştır.

\section{Uygulama Süreci}

Leonardo Da Vinci'nin “Son Akşam Yemeği” adlı eserinin yaratıcı drama yöntemiyle çözümlenmesi ve alımlanması kapsamında altı konu belirlenerek yaratıcı drama yöntemi aşamaları (1sınma/hazırlık, canlandırma, değerlendirme) doğrultusunda yapılandırılmıştır. Uygulama atölyeleri toplam 24 saat olmak üzere 8 oturumda 4 Haziran 2013 - 19 Haziran 2013 tarihleri arasında gerçekleştirilmiştir. Oturum başlıkları; "Tanışma - İletişim”, "Sanatta Yaratma ve Yaratııılık", "Bir Sanat Eserindeki Tasarım İlkeleri ve Öğeleri”, "Son Akşam Yemeği Adlı Resimdeki İçerik”, "Son Akşam Yemeği Adlı Resimde Mekan ve Kişiler”, "Son Akşam Yemeği Adlı Resimdeki Giysiler ve Yemek”, Leonardo Da Vinci’nin Hayatı ve Sanat Anlayışı” ve “Genel Değerlendirmedir”. 


\section{Bulgular ve Yorum}

Araştırma kapsamında ulaşılan bulgular, araştırma soruları ile ilişkili olarak; Sanat Eseri, Yaratıcı Drama Aracılığıyla Sanat Eseri İnceleme, Sanat Eserinde Biçim ve İçerik, Yaratıcı Drama ve Sanatsal Düzenleme Öğeleri olmak üzere beş alt başlıkta sunulmuştur.

\section{Sanat Eseri}

Sanat eseri alt başlığında, öğrencilerin bu çalışmadan önce ve sonra bir sanat eserine nasıl baktıkları belirlenmeye çalışılmıştır. Öğrencilerin sanat eserine bakmakla ilgili görüşleri Tablo 1'de gösterilmiştir.

Tablo 1. Sanat Eserine Bakmakla İlgili Öğrenci Görüşleri

\begin{tabular}{ll}
\hline Sanat Eseri & \multicolumn{1}{c}{ Öğrenci Görüşleri } \\
\hline & Ö.1. Resimlere öyle bakar geçerdim ya güzel ya da çirkin derdim ama şimdi artık sanatsal \\
& ögeleri kullanıp detaylarına bakabiliyorum. \\
& Ö.4. Önceden sadece resimlere bakıp iyi ve güzel deyip geçiştirirdim. Ama şimdi bir sürü \\
& yorum yapabiliyorum. Resimde yüz ifadelerine kıyafetlerine yemeklerine ve duruşlarına \\
& çok dikkat ediyorum. \\
& Ö.5. Yaratıcı drama etkinliklerine katılmadan önce bir sanat eserinin öğelerine dikkat \\
& etmezdim. Şimdi resmin öğelerini dikkate alarak resimdeki hareket ve mimikleri de dikkate \\
& alıorum. \\
& Ö.10. Normal bir şekilde güzelse güzel olmuş deyip geçerdim. Ama şimdi temel sanat \\
& öğelerine bakarak ve tablonun inceliklerine bakarak resmi daha iyi görebiliyorum. \\
& Ö.7. Önceden bir resme bakıp aa güzelmiş deyip geçerdim. Ama şimdi neler oluyor ve \\
& resimde neler var diye bakıyorum. \\
& Ö.11. İlk başta bakar geçerdim. Bunlar boşuna yapıorlar derdim ama şimdi çok güzel bir \\
& resim ve duruşları çok güzel diyorum. \\
& Ö.14. Herkesin merak ettikleri şeyler çok önemli olur ve onun neden çağlar boyunca merak \\
& edildiğini artık biliyorum.
\end{tabular}

Tablo 1'de öğrencilerin, sanat eserine bakmakla ilgili görüşleri incelendiğinde, bir sanat eseriyle ilk kez karşılaştıkları zaman hızlıca bakıp geçtikleri ve eser hakkında herhangi bir yargıda bulunmadıkları görülmüştür. Bunun yanında eserin kime ait olduğu, kim tarafından yapıldığı ve içeriğiyle ilgili bilgilerinin olmadığını belirtmişler ve eserlerin neden bu kadar değerli olduklarını anlamadıklarını ifade etmişlerdir. Öğrencilerin yaratıcı drama etkinliklerinden sonra süreç boyunca eser hakkındaki bilgileri çözümleyerek eseri daha iyi anladıkları, resimden ne anladıklarını yorumladıkları görülmüştür. Ayrıca eserlerdeki sanat elemanları ve tasarım ilkelerine de dikkat ederek resmi daha iyi anladıklarını söylemişlerdir.

\section{Yaratıcı Drama Aracılığıyla Sanat Eseri İnceleme}

Yaratıcı drama aracılığıyla sanat eseri inceleme alt başlığında, öğrencilerin Leonardo Da Vinci'nin Son Akşam Yemeği adlı eserinin yaratıcı drama etkinlikleriyle işlenmesi hakkındaki düşünceleri belirlenmeye çalışılmıştır. Öğrencilerin "Yaratıcı Drama Aracılığıyla Sanat Eseri İncelenmesine ilişkin görüşleri Tablo 2'de gösterilmiştir. 
Tablo 2. Leonardo Da Vinci’nin "Son Akşam Yemeği”" Adlı Eserinin Yaratıcı Dramayla İşlenmesi ile İlgili Öğrenci Görüşleri

\section{Sanat Eseriyle}

Darama

\section{Öğrenci Görüşleri}

Ö.2. Bence bu şekilde işlenmesini çok sevdim. Hem eğlendim hem öğrendim yani bu konuda çok olumlu pozitif düşünüyorum.

Ö.4. Canlandırmalar yaptık ve doğaçlamalar yaptık. Biz burada o tabloyu
canlandırdığımız için onların ne hissettiklerini ve neler yaşadığını anladım.
Ö.5. Yaratıcı drama da hem oyun oynayıp hem de eğleniyorum. Çünkü elimize bir kağıt verilip de okumamız istenseydi çok çabuk unuturduk ama şimdi eğlenerek daha iyi öğreniyoruz.
Ö.8. Son Akşam Yemeği tablosunda ayrıntılı bir şekilde öğreniyoruz. Oyunlarla canlandırmalarla daha iyi bir şekilde öğrendik.
Ö.10. Konuşarak bir şey anlaşılmıyor ama etkinlik yaparken eğlenerek öğreniyoruz. Bu da çok daha kalıcı oluyor.
Ö.12. Eğlenceliydi. Yaptığımız etkinlikler güzeldi ama ufak bazı sorunlar oldu. Ama arkadaşlar arasında olur böyle şeyler.

Ö.14. Konuyu eğlenerek öğrendik ve etkinlikler daha iyi anlamamıza yol açtı ve bu çok güzel bir şey.

Tablo 2'de öğrencilerin yaratıcı drama aracılığıyla sanat eseri incelemesine ilişkin görüşlerine bakıldığında, Leonardo Da Vinci'nin Son Akşam Yemeği adlı eserinin yaratıcı drama etkinlikleriyle işlenmesinin hem eğlendirici hem de öğretici olduğunu belirtikleri görülmüştür. Bunun yanı sıra tabloyla ilgili yapılan doğaçlama ve canlandırmaların resmi daha iyi anlamalarını sağladığı, canlandırmalarla resimdeki kişilerin ne hissettiklerini ve neler yaşadıklarını da kavradıklarını ifade etmişlerdir. Ayrıca öğrencilerin görüşlerine baktığımızda, dersin klasik bir şekilde işlenmesinin sıkıcı olacağ 1 bunun yerine oyunun ve eğlencenin olduğu bir dersin ise onlara daha çok şey öğreteceği ve kalıcı olacağını belirtmiş oldukları görülmüştür.

\section{Sanat Eserinde Biçim ve İçerik}

Sanat eserinde biçim ve içerik alt başlığında, öğrencilerin Leonardo Da Vinci’nin “Son Akşam Yemeği” adlı resminin biçim ve içeriğini anlamalarıyla ilgili düşünceleri belirlenmeye çalışılmıştır. Öğrencilerin sanat eserinde biçim ve içerik ilişkisine ilişkin görüşleri Tablo 3’te gösterilmiştir. 
Tablo 3. Leonardo Da Vinci’nin "Son Akşam Yemeği”" Adlı Resminin biçim ve İçeriği ile İlgili Öğrenci Görüşleri

\begin{tabular}{|c|c|}
\hline $\begin{array}{l}\text { Sanat Eserinde } \\
\text { Biçim-İçerik }\end{array}$ & Öğrenci Görüşleri \\
\hline 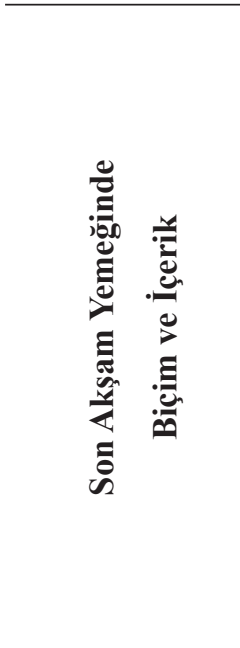 & $\begin{array}{l}\text { Ö.2. Bence bu şekilde işlenmesini çok sevdim. Hem eğlendim hem öğrendim yani bu } \\
\text { konuda çok olumlu pozitif düşünüyorum. } \\
\text { Ö.4. Evet düşünüyorum. Çünkü son akşam yemeği olduğu için yemekleri ve mekân } \\
\text { seçimleri çok önemli. } \\
\text { Ö.6. Evet düşünüyorum. Çünkü o konu ile ilgili oyun oynadık ve birçok şey yaparak } \\
\text { anladığımı düşünüyorum. } \\
\text { Ö.8. Evet düşünüyorum tablo içeriği, kişiler, yemek ve mekân, toplanma nedenleri bunun } \\
\text { yanında yüz ifadelerini daha iyi anladım. } \\
\text { Ö.10. Evet en çok temel sanat öğeleri ve estetik değerler yardımcı olduğunu düşünüyorum. } \\
\text { ÖK.12. Evet en çok da temel sanat öğelerini anladım. } \\
\text { Ö.14. Giysiler renkler ve döneme ve insana göre değişebilir. Örneğin kişinin kıyafetlerinin } \\
\text { rengine bakarak o kişinin özelliklerini anlayabiliyor ve tahmin edebiliyorum. }\end{array}$ \\
\hline
\end{tabular}

Tablo 3'te öğrencilerin, sanat eserinde biçim ve içerik özelliklerine ilişkin görüşlerine bakıldığında Leonardo Da Vinci'nin “Son Akşam Yemeği” adlı resminin biçim ve içeriğini anladıklarını ifade ettikleri görülmüştür. Öğrenciler resimdeki biçim ve içeriğin sanat elemanları ve tasarım ilkeleriyle daha çok anlam kazandığını belirtmişlerdir. Ayrıca katılımcılar, resimdeki insanlar, mekân, yemek ve toplanma nedenleriyle ilgili düşüncelerini de söylemişlerdir.

\section{Yaratıcı Drama}

Bu alt başlıkta da öğrencilerin yaratıcı drama uygulamalarına yönelik görüşleri belirlenmeye çalışılmıştır. Öğrencilerin yaratıcı drama uygulamalarına ilişkin görüşleri Tablo 4’te gösterilmiştir.

Tablo 4. Leonardo Da Vinci'nin "Son Akşam Yemeği”" Adlı Tablosunun Yaratıcı Dramayla İslenmesi ile Ilgili Öğrenci Görüşleri

\begin{tabular}{ll}
\hline Yaratıı Drama & Öğrenci Görüşleri \\
\hline & $\begin{array}{l}\text { Ö.2. Ben bu süreçte çok eğlendim. Kıyafetler tasarladım bilgiler öğrendim yeni yeni } \\
\text { arkadaşlar edindim. O yüzden gerçekten çok mutluyum. }\end{array}$ \\
& Ö.3. Bu süreçte oyunlar oynadık ve eğlenerek öğrendik. Eğlenerek öğrenmek \\
& gerçekten de çok güzel bir yöntem. \\
& Ö.5. Evet gönüllü katıldım. Bu süreçte eğlendik oyunlar oynadık ve çok mutlu bir \\
& süreç geçirdik. \\
& Ö.7. Evet gönüllü katıldım. Canlandırmalar yaptık. Oyunlar oynadık, eğlendik ve \\
& resmi çözümledik. \\
& Ö.9. Kendi isteğimle katılım. Bazen güldük bazen eğlendik bazen üzüldük bazen de \\
& sıkıldığımız oldu ama çok güzeldi. \\
& Ö.11. Çok eğlendim ve çok sevdim. Resimde bir şey yapmışsam çok mutlu oluyorum. \\
& Ö.15. Herhangi bir drama çalışması yaratıcı olması için bir grubun olması gerekir. \\
& Yaratıcı drama eğlenerek öğrenmektir.
\end{tabular}


Tablo 4’te öğrencilerin, yaratıcı drama uygulamalarına ilişkin görüşlerine baktığımızda hepsi yaratıcı drama etkinliklerine gönüllü katıldıklarını ifade etmişlerdir. Süreç boyunca çok eğlendikleri, oyunlar oynadıkları, kıyafetler tasarladıkları ve yeni arkadaşlıklar edindiklerini belirtmişlerdir. Ayrıca öğrenciler eğlenerek öğrenmenin kendilerini çok mutlu ettiğini ve derste kullanılan bu yöntemin çok güzel bir yöntem olduğunu da söylemişlerdir. Öğrencilerden birkaçı ise oyunlarda bazen sıkıldıklarını fakat genel itibariyle güzel zaman geçirdiklerini ifade etmişlerdir.

\section{Sanatsal Düzenleme Ögeleri}

$\mathrm{Bu}$ alt başlık altında da öğrencilerin bir sanat eserinde sanatsal düzenleme ögelerini (çizgi, şekil, 1ş1k- gölge, doku, renk, biçim, değer, ton, mekân vb.) görüp göremedikleri belirlenmeye çalışılmıştır. Öğrencilerin sanatsal düzenleme ögelerine ilişkin görüşleri Tablo 5'te gösterilmiştir.

Tablo 5. Sanat Eserinde Sanatsal Düzenleme Ögelerini Görme ile İlgili Öğrenci Görüşleri

\begin{tabular}{ll}
\hline Sanat Ögeleri & Öğrenci Görüşleri \\
& $\begin{array}{l}\text { Ö.2. Evet artık görebiliyorum. Çünkü önce bunlara önem vermeyip bakıp geçerdim ama } \\
\text { artık böyle olmayacak. }\end{array}$ \\
& Ö.3. Evet kesinlikle görebiliyorum. Artık resimlere bakarken bu sanatsal düzenleme \\
& ögelerine dikkat ediyorum. \\
& Ö.5. Evet görebiliyorum çünkü bütün ögeleri yaparak ve yaşayarak öğrendik. \\
& Ö.8. Evet görebiliyorum. perspektifi çizgiyi, dokuyu, mekânı, tonu, gölgeyi, rengi, şekli \\
& Ö.9. Evet benim bildiğim kadarı̈yla her sanatta ve eserlerde bu ögeler vardır ve \\
& Ö.13. Biçim, perspektif, çizgi, gölge, doku, renk, zıtlık ve denge sanatsal düzenleme \\
& ögeleri olarak geçmektedir. \\
& Ö.15. Sanatsal düzenleme ögeleri öğrendim ve bunlar son akşam yemeği resmini \\
& anlamamızı sağladı
\end{tabular}

Tablo 5'te öğrencilerin sanatsal düzenleme ögelerine ilişkin görüşlerine baktığımızda bir sanat eserinde sanatsal düzenleme ögelerini (çizgi, şekil, 1ş1k- gölge, doku, renk, biçim, değer, ton, mekân v.b) görebildikleri belirlenmiştir. Daha önce bir sanat eseriyle karşılaştıklarında bu tür ögeleri göremediklerini (bilmedikleri), görmüş olsalar bile bu ögelerin onlar için bir anlam ifade etmediği dile getirilen görüşler arasındadır. Ayrıca bundan sonra bir sanat eseriyle karşılaştıklarında ilk dikkat edecekleri şeylerin bu ögeler olacağını da belirtmişlerdir. Öğrencilerin yaratıcı drama etkinlikleriyle sanat elemanları ve tasarım ilkelerini yaparak ve yaşayarak daha iyi çözümlediklerini ifade ettikleri de görülmüştür.

\section{Tartışma}

$\mathrm{Bu}$ araştırma öncelikle Leonardo Da Vinci’nin Son Akşam Yemeği adlı eserini temel almıştır. Araştırmada eserden yola çıkarak katılımcıların eseri çözümleme ve alımlamada yaratıcı drama yönteminin kullanılmasının öğrenci görüşlerine göre değerlendirilmesi istenmiştir. $\mathrm{Bu}$ amaç doğrultusunda çalışmanın bulgu ve yorumlarından çıkan sonuçlara bakıldığında Leonardo Da Vinci'nin Son Akşam Yemeği adlı eserinin yaratıcı drama yöntemiyle çözümlenmesi ve 
alımlanmasında öğrencilerin estetik deneyimleri, eseri çözümleme ve öğrenme süreçlerinde artışın olduğu tespit edilmiştir. Alan yazınına baktı̆̆ımızda yapılan araştırmalar, yaratıcı drama yönteminin öğrencilerin başarılarına anlamlı bir etkisinin olduğunu, yine bu yöntemin öğrencilerin öğrenme düzeylerinde de artışı sağladığını göstermiştir. Aykaç (2007) 5. sınıf sanat etkinlikleri dersinde "Müze Kültürü” öğrenme alanına bağlı "Tarihte Yaşam Kültürü” temasının öğretiminde öğrenci memnuniyetini yaratıcı drama yöntemini kullanılarak değerlendirmiştir. Uygulama sonucunda yaratıcı dramayla müzeye dönüştürülen sınıf ortamının ve müzelerin öğrenci motivasyonunu artırdığı, öğrenmenin kalıcılığını sağladığı ve öğrencinin mutluluğu üzerinde önemli bir etki yarattığını gözlemlemiştir. Uyan (2006) ise resim derslerini geleneksel yöntem ve drama yöntemi kullanarak işlediği tezinde, yaratıcı dramanın öğrencilerin derslerindeki başarılarını artırdığını gözlemlemiştir. Aynı şekilde Topçu da (2008) tezinde, görsel sanatlar dersinde 8 yaş grubu öğrencileriyle bir yaratıcı drama uygulaması yaparak süreç sonunda çıkan resimleri değerlendirmiştir. Bulgular, öğrencilerin yaratıcı dramayla işlenen ders boyunca eğlendiklerini, eğlenceli bir ders ortamı oluşturduklarını ve resim yaparken daha çok zevk aldıklarını göstermiştir. Ayrıca bu çalışmayla öğrencilerin gözlem ve düş güçlerini kullanarak ortaya çıkardıkları ürünlerde kendilerini rahatlıkla ifade ettikleri bulgular arasında yer almaktadır. Başka bir araştırmada da Kaya (2006), ilköğretim 3. sınıf öğrencileriyle görsel sanatlar dersinde drama yöntemiyle işlenen dersin öğrencilerin ilgilerini artırdı̆̆ını, onları çalışmaya daha istekli kıldığını ve öğrencilere çalışma disiplini kazandırdığını göstermiştir.

Yapılan araştırmalar öğrencilerin sanat eserlerini anlama ve kavramada geleneksel yöntemlerle öğrenmenin yeterli olmadığını, öğrencilerin yaparak ve yaşayarak öğrendiği yöntemlere ihtiyaçlarının daha çok olduğunu ortaya çıkarmıştır. Catterall ve Nugent (Akt. Bağatır, 2008), "Öğrenciler dünyalarında ve ilişkilerinde pasif ve evcil değil, aktif ve eleştirel olmalıdır". Öğrenmenin merkezinde olan öğrencinin aktif ve eleştirel olması için de öğretim yöntemlerinin bu aktifliği ve dinamikliği sağlayacak içeriğe sahip olması gerekir. Yaratıcı drama tam da burada karşımıza çıkmaktadır. Üstündağ’a $(2005,24)$ göre, “Öğretimde önemli olan, öğrenciyi edilgenlikten kurtararak bedenini ve duyu organlarını harekete geçirmektir. Yaratıcı dramayla öğrenciler konuların öğrenilmesine etkin olarak katılarak kendi yaptığıyla öğrenerek diğer yandan duyu organlarını da harekete geçirerek olay ya da durumları yaşamaktadır”.

Burçoğlu ve Aykaç (2013) çalışmalarında Neşet Günal'ın eserlerini yaratıcı drama yöntemiyle incelemiştir. Çalışmanın sonuçları öğrencilerde Neşet Günal'ın eserlerine karşı bakış açılarında olumlu değişimler göstermiştir. Öğrencilerin, eserlere daha iyi ve daha dikkatli bakma, eserlerden yola çıkarak neden sonuç ilişkisi kurma ve temel plastik değerlerle eserleri inceleme ve yorumlamayla gelen sonuçlar elde ettiğini belirtmişlerdir. Benzer bir çalışma Arıkız ve Beştepe (2016)'nin araştırmasında da teknoloji tasarım dersinin yaratıcı drama ile işlendiğinde dersin daha iyi anlaşıldığ yönündedir. Yapılan çalışmalar (Aykaç, 2007; Uyan, 2006; Topçu, 2008; Kaya, 2006; Burçoğlu ve Aykaç, 2013; Arıkız ve Beştepe, 2016 ) göstermektedir ki yaşanan gelişmelerle birlikte sanat eğitiminde olduğu gibi öğrencilerin sanat eserlerini kavramaları için geleneksel yöntemlerin yanında yaratıcı drama gibi pek çok disiplinlerarası yönteme de ihtiyaç duyulmaya başlanmıştır.

Yukarıdaki belirtilenler çerçevesinde drama yöntemi kullanılan bu çalışmada süreç boyunca öğrencilerin derse daha heyecanlı geldikleri ve sanat eserlerine karşı ilgilerinin arttı̆̆ gözlemlenmiştir. Çalışmaya başlarken yapılan ısınma hareketleri öğrencileri derse daha hızlı hazırlamış ve dikkatlerini daha fazla toplamalarını sağlamıştır. Doğaçlamalarda katılımcılar yaparak ve yaşayarak konuyu 
daha iyi kavramışlar, canlandırmada olay örgüsünü kurmaları ve bu olay örgüsünden yola çıkarak sonuca ulaşmaları daha hızlı olmuştur. Son olarak öğrencilerin ifadelerine baktı̆̆ımızda ise süreç boyunca yaşadıklarını, hissettikleri duyguları ve kendilerinde bıraktıkları izlenimleri ifade ettikleri görülmüştür. Araştırma boyunca katılımcıların çoğunluğu sanata bakış açılarının değiştiğini, sanat eserini çözümlemede eleştirel düşünme becerilerinin geliştirdiğini ifade etmişlerdir.

\section{Sonuç}

Drama yöntemiyle işlenen araştırma süreci, katılımcıların eleştirel anlamda daha fazla pratik yapmalarına olanak sağlamış ve öğrencilerin tutumlarında da olumlu değişimlerin olduğu görülmüştür. Katılımcıların sınıfta ve sınıf dışında eleştirel tutumlar sergiledikleri gözlemlenmiş ve özellikle bazı öğrencilerin etkinlikler sonunda evlerine döndüklerinde duvarlarda asılan resimleri yorumladıkları ve bu resimler hakkında aileleriyle konuştukları dile getirilmiştir. Bu bağlamda Leonardo Da Vinci'nin Son Akşam Yemeği adlı eserinin yaratıcı drama yöntemiyle çözümlenmesi ve alımlanmasında katılımcıların estetik deneyimlerinde, eseri çözümleme ve alımlama süreçlerinde gelişmenin olduğu gözlemlenmiştir. Bir resme nasıl bakılacă̆1, Son Akşam Yemeği resminin biçim içerik özelliklerinin, Son Akşam Yemeği resmi üzerinden sanatsal düzenleme ögelerinin öğrenciler tarafından öğrenildiği belirlenmiş̧ir. Araştırmanın tüm bulgularına bakıldığında, bir sanat eserinin yaratıcı drama yöntemiyle işlenmesi sonrasında yöntemin öğrencilere sanat eserleri ile ilgili farklı bakış açıları kazandırılabileceği ve öğrencilerde sanata karşı farkındalık oluşturulabileceği görülmüştür.

Araştırmada ulaşılan sonuçlardan hareketle; tüm öğretim kademelerinde, sanat eğitimi ile ilgili derslerde ve sanat eseri çözümleme ya da sanat eleştirisi uygulamalarında yaratıcı drama yönteminden yararlanılması önerilmektedir. 


\section{Kaynakça}

Arıkız, S. ve Beştepe, N. E. (2016). Tasarım sürecinde yaratıcılık "Teknoloji ve tasarım dersinin yaratıı drama yöntemiyle işlenmesi. Yaratıcı Drama Dergisi, 11(2), 47-64.

Aykaç, M. (2007). İlköğretim sanat etkinlikleri dersinde yaratıcı drama yönteminin öğrenci memnuniyeti açısından değerlendirilmesi. Yaratıcı Drama Dergisi, 1(3/4), 27-44.

Aykut, A. (2011). Sanat eğitiminde estetik. İstanbul: Hayalperet Yayınevi.

Bağatır D., R. (2008). Drama öğretim yönteminin resim- iş bölümü öğrencilerinin mesleki tutum ve başarılar1na etkisi. Yayımlanmamış doktora tezi, Dokuz Eylül Üniversitesi Eğitim Bilimleri Enstitüsü, İzmir.

Beştepe, N. E. (2006). Sanat eleştirisinde ölçüt sorunu. Mustafa Kemal Üniversitesi Sosyal Bilimler Enstitüsü Dergisi, 3(6). 1-9.

Botton, A. (2007). Mutluluğun mimarisi. İstanbul: Sel Yayınc1lık.

Burçoğlu, E. B. ve Aykaç, M. (2013). Sanat eserlerinin yaratıcı drama yöntemiyle incelenmesi. Mersin Üniversitesi Eğitim Fakültesi Dergisi, 9 (2), 181-191.

İlhan, A.Ç. (2007). Yaratıcı drama ile örtüşen çağdaş sanat akımları. Yaratıcı Drama Dergisi, 1(3-4), 139-154.

İlter, İ. (2014). Öğretim elemanlarının kullandığı yöntem ve tekniklere ilişkin öğretmen adaylarının görüşleri. Journal of International Social Research, 7(35). 562-575.

Kaya, Ö. (2006). İlköğretim 3. sınıf görsel sanatlar dersinde drama destekli eğitimin yaratıcı sürece katkıları. Yayımlanmamış yüksek lisans tezi, Gazi Üniversitesi Eğitim Bilimleri Enstitüsü, Ankara.

Özer, B. (2000). Kültür sanat mimarlık. İstanbul: Yem Yayın.

Read, H. ve Asgari, N. (2014). Sanatın anlamı. İstanbul: Hayalperest Yayınları.

Sağlam, T. (2006). Gavin Bolton: Drama, sanat, öğrenme. Yaratıcı Drama Dergisi. 1(2), 57-64.

San, İ. (1979). Sanatsal yaratma ve çocukta yaratıcılık. Ankara: Türkiye İş Bankası.

Tanilli, S. (1999). Yaratıcı aklın sentezi: Felsefeye giriş. Ankara: Adam Yayınları.

Topçu, A. K., (2008). Görsel sanatlar eğitiminde bir öğretim yöntemi olarak yaratıcı drama . Yayımlanmamış yüksek lisans tezi. Selçuk Üniversitesi Sosyal Bilimler Enstitüsü, Konya.

Uyan, Z. (2006). Resim öğretiminde (sanat eğitiminde) oyunun öğretime katkısı. Yayımlanmamış doktora tezi, Dokuz Eylül Üniversitesi Eğitim Bilimleri Enstitüsü, İzmir.

Üstündağ, T. (2002). Yaratıcı dramanın üç boyutu. Ö. Adıgüzel (Yay. Haz..) Yaratıcı Drama 1985-1998 Yazılar içinde (s. 333-341). Ankara: Natürel Yayıncılık.

Üstündağ T. (2005). Yaratıcllı̆a yolculuk. Ankara: Pegem Yayıncılık.

Vural, R. A. ve Somers, J.W. (2011). İlköğretimde drama kuram ve uygulama. Ankara: Pegem Yayınları.

Yıldırım, A. ve Şimşek, H. (2006). Sosyal bilimlerde nitel araştırma yöntemleri. Ankara: Seçkin Yayınları.

Yolcu, E. (2009). Sanat eğitimi kuramları ve yöntemleri. Ankara: Nobel Yayınları. 


\section{Ek1: Örnek Ders Planı (Üçüncü Oturum)}

Tarih : 06.06.2013

Yer : MEB'e Bağlı Bir Devlet Ortaokulu

Süre $\quad: 180 \mathrm{dk}$.

Konu : Bir Sanat Eserindeki Sanatsal Düzenleme Öğeleri (Leonardo da Vinci’nin Son Akşam Yemeği resminden hareketle)

Grup $\quad: 14 \mathrm{~K}$ ız, 2 Erkek $(10-11$ yaş arası toplam 16 katılımcı)

Yöntem : Yaratıcı Drama

Teknik : : Rol Oynama, Doğaçlama, Donuk İmge

Araç- Gereçler: Müzik (Shantel - Ex Oriente), Yaka Kartı, Sanatsal Düzenleme Öğelerini Gösteren Dijital Baskılar, 35x50 Resim Kağıdı, Yapıştırıcı, Pet Şişe Kapağ1, Kağıt, Gazete, Dergi,Taş İp, Pipet

\section{Kazanımlar:}

Sanatsal düzenleme öğelerini (çizgi, şekil, 1şık- gölge, doku, renk, biçim, değer, ton, mekan) kavrar.

Bir sanat eserinin oluşmasında sanatsal düzenleme öğelerinin önemini fark eder.

\section{Süreç}

\section{Hazırlık-Isınma}

\section{Etkinlik}

Lider, önceden hazırlanmış renkli yaka kartlarına yazılmış olan tasarım ve sanatsal düzenleme öğelerinin isimlerini katılımcılara dağıtarak bunları yakalarına takmalarını söyler. Katılımcılara bu yaka kartlarında yazılmış olan kelimelerin kendi isimleri olduğu söylenir. Daha sonra Lider o isimlerden birini ebe olarak seçer. Ebe müzik eşliğinde katılımcılardan birini ebelemek için koşar. Ebeleneceğini anlayan kişi başka birinin ismini (sanatsal düzenleme öğeleri) söylerse ebe o kişi olur ve ebe o yöne doğru koşar. Etkinlik belli bir süre devam ettirilir.

\section{Etkinlik}

Lider, tasarım ve sanatsal düzenleme öğelerinin isimlerinin yazılı olduğu yaka kartlarını katılımcılara tekrar dağıtır. Liderin kendisi de bir yaka kartı takarak ben bir resme baktım içinde (yaka kartında yazılı olan öğe) doku vardı ama renk yoktu diyerek etkinliği başlatır. Renk öğesinin yazılı olduğu katılımcı da bir başka katılımcının yakasında yazılı olan öğeyi aynı cümle içerisinde kullanarak etkinliği devam ettirir.

\section{Etkinlik}

Lider sınıfın duvarlarına çizgi, şekil, ışık- gölge, doku, renk, biçim, değer, ton, mekan gibi sanatsal düzenleme öğelerini gösteren resimleri asar. Katılımcılardan bu resimlerin altına resimlerin ne olduklarıyla ilgili birer kelime yazmaları istenir. Burada katılımcılardan resmin altında daha önce ne yazıldığından çok kendileri için ne ifade ettiğinin önemli olduğu vurgulanır. Etkinlik bitiminde resimler gezilerek yazılan ortak kelimeler lider tarafından kalemle daire içine alınır. 


\section{Etkinlik}

Lider önceden hazırlamış olduğu tasarım öğelerinin yazılı olduğu bilgi kartları kapalı bir biçimde atölyenin zeminine dağınık bir şekilde bırakılır.

Bilgi kartlarındaki tasarım ilke ve öğelerini açıklayan yazılarının anlaşılabilir, kısa ve öz olmasına dikkat edilmiştir. Tüm katılımcılara, bir müzik açılacağı ve müzikle beraber yerde kapalı duran kâğıtların etrafinda dolaşmaları ve müzik durduğunda, o an bulundukları yere yakın olan kâğıdı alıp okumaları söylenir.

Müzik tekrar başladığında aldıkları kâğıdı aynı yere kapalı bir şekilde bırakıp müzik eşliğinde tekrar dolaşmaları istenir.

Katılımcıların yerdeki kâğıtların tümünü okuması sağlandıktan sonra etkinlik sonlandırılır.

\section{Etkinlik}

Lider katılımcılar çemberdeyken daha önceden hazırlayıp kapalı bir torbaya karışı bir şekilde koyduğu tasarım ilkelerini anlatan özlü sözleri katılımcıların tek tek torbadan çekmeleri sağlanır. Katılımcılardan mekanın ortasına gelerek torbadan çekilen kağıtta yazılanı gür ve anlaşı1ır bir sesle okuyup donuk imgeyle göstermeleri istenir. Tüm katılımcılar okuyana kadar etkinlik devam ettirilir.

Torba içerisinde bulunan Tasarım ilke ve öğelerinden yola çıkarak yazılan yazılar;

1. Ben bir Çizgiyim; Bir ip gibiyim. Bükülüp her şekle girebilirim.

2. Ben Işık- Gölgeyim; Ben olmadan hiçbir şey göremezsiniz.

3. Ben bir Şekilim; Beni görebilir ve neye benzediğimi söyleyebilirsiniz.

4. Ben bir Dokuyum; Bana bakarak ve dokunarak hissedebilirsiniz.

5. Ben bir Rengim; Her yerde beni görebilirsiniz.

6. Ben bir Biçimim; Bana dokunabilir ve etrafımda dönebilirsiniz.

7. Ben bir Ton'um; Hem açılıp, hem kapanabilirim.

8. Ben bir Mekanım; Her yerde ben varım. Çünkü siz her zaman bir mekanın içindesiniz.

\section{Canlandirma}

\section{Etkinlik}

Lider katılımcıları 3 gruba ayırır. Lider katılımcılara karşınızda hayali bir tablo var. Fakat bu tablo henüz oluşmamış. Her katılımcıdan bu hayali tabloyu tasarım öğelerinden birini seçerek oluşturmanız isteniyor. Bu durumda sizler konuşan canlı birer tasarım öğesisiniz. Tablonun içerisine girip orada kendinize bir yer bulmanız ve sizden sonra gelecek öğelere izin vermemeniz isteniyor. Eğer gelirlerse neden buraya geldiklerini sormanızı ve onlara gerek duyulmadığını söylemeniz isteniyor. İzin verecekseniz onlardan mantıklı bir sebep bulmalarını isteyeceksiniz. Sonradan tabloya giren katılımcılara da ben (biz) olmadan tablonun eksik kalacağı, çünkü..........ile başlayan bir cümleyi tamamlamaları istenir. Lider el çırpar ve bir öğe tabloya dahil olur. Her katılımcıya tasarım öğelerinin o ana kadar hangisi söylenmemişse onunla dahil olunacağı hatırlatılır. 
Her giden bir öncekinin sorularına maruz kalıp neden burada olduklarını ve ben ya da biz olmadan tablonun eksik kalacağını savunmaları istenir.

Tüm katılımcılar tabloya dahil olana kadar etkinlik devam ettirilir.

\section{Etkinlik}

Röprodiksiyon: Orijinal bir resmin bakarak yeniden yapılması " kopya edilmesi şeklinde katılımcılara söylenir. Katılımcılardan ikişer kişilik gruplar oluşturmaları istenir. İkililerden biri A diğeri B olur. Lider her gruptan B olanlara sanatsal düzenleme öğelerinden birini verir ve yönergesini ekler:

' 'A' lar sizler ünlü bir ressamsınız. Günlerce çalıştığınız çalışma Leonardo'nun “Son Akşam Yemeği” adlı tablosunun röprodüksiyonu (yeniden yapma). Tabloyu günlerce uğraşıdan sonra bitirdiniz. Bitirdiğiniz gün galeri sahibi arkadaşınızı çağırıyorsunuz. Çünkü paraya ihtiyacınız var ve tabloyu satmak için ikna etmelisiniz."

"B” ler sizler galeri sahibisiniz. Ressam arkadaşınız sizi bitirdiği resmi görmeniz için davet ediyor. Çok merak ediyorsunuz. Ve gittiğinizde resmi özellikle size verilen tasarım öğesinin eksik olduğunu kontrol ediyorsunuz. Buna göre bir karar vermeniz gerekiyor.

Doğaçlamalar A'ların hoşgeldin demesiyle başlar.

\section{Değerlendirme}

\section{Etkinlik}

Lider öğrencilere 35x50 resim kağıdı, yapıştırıcı ve pet şişe kapağı, kağıt gazete, dergi, taş, ip, pipet, bu ve benzeri artık malzemeleri ve her bir gruba yeterli miktarda dağıtır. Daha sonra katılımcılardan dağıtılan bu artık malzemeleri de kullanarak tasarım öğelerini göz önünde bulundurup bir kolaj(kes-kopar düzenle ve yapıştır) çalışması yapmaları istenir. Yapılan tüm çalışmalar gezilerek üzerinde konuşulur. 



\title{
Yaratıcı Drama Eğitmenlerinin Sosyal Adalet Tutumlarının İncelenmesi*
}

\author{
Serkan Keleşoğlu ${ }^{1}$ \\ İhsan Metinnam ${ }^{2}$
}

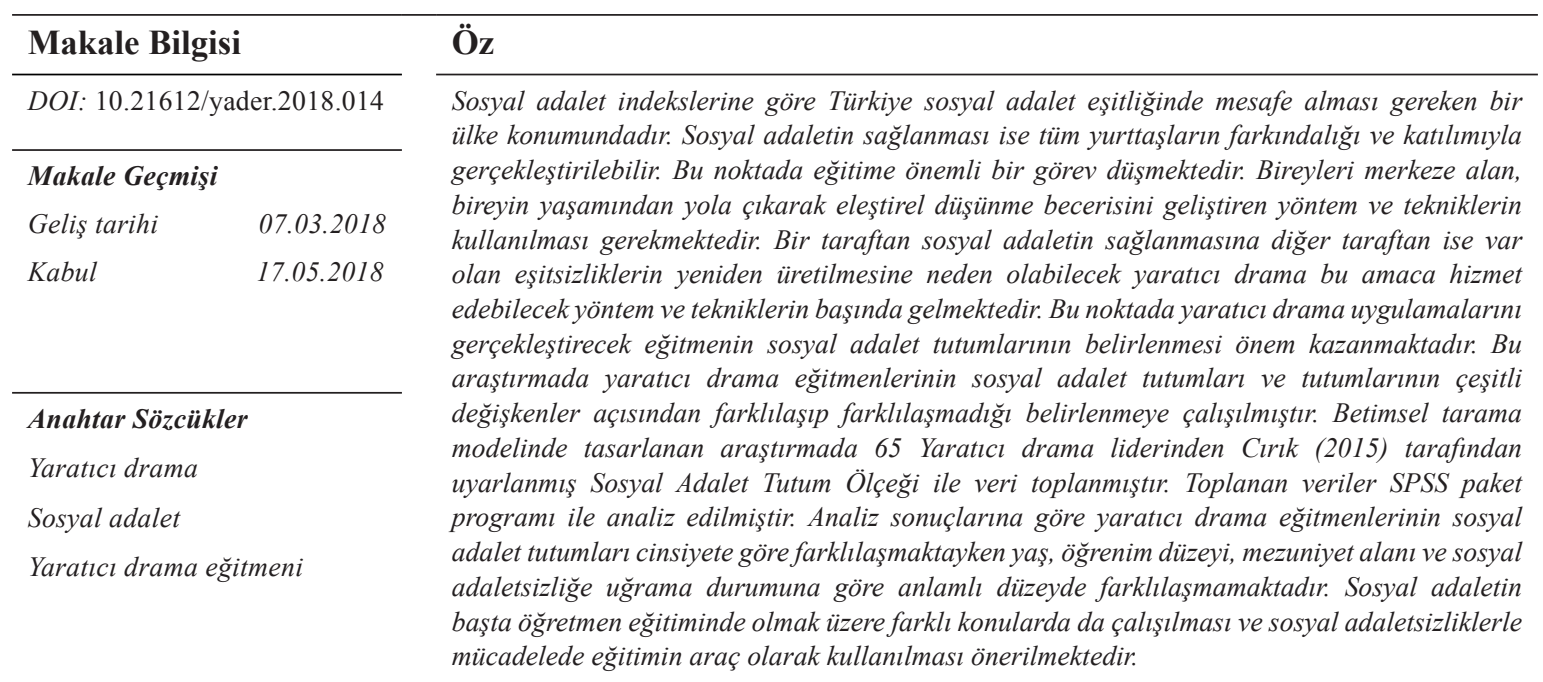

\section{Investigation of Social Justice Attitudes of Creative Drama Trainers}

\begin{tabular}{lr}
\hline Article Info \\
\hline DOI: 10.21612 /yader.2018.014 \\
\hline Article History & \\
Received & 07.03 .2018 \\
Accepted & 17.05 .2018
\end{tabular}

Keywords

Creative drama

Social justice

Creative drama trainer

\begin{abstract}
According to the Social Justice index, Turkey is a country that needs to make progress in social justice equality. The provision of social justice can be achieved through the awareness and participation of all citizens. Education at this point has an important task. In this context, it is necessary to use the methods and techniques that are individual-centered, come from the individual's experiences, and develop the critical thinking skills. Creative drama that can lead to social justice on the one hand and the reproduction of the existing injustice on the other is at the forefront of the methods and techniques that can serve this purpose. Because creative drama trainer who plans, implements, and evaluates the process has an important role in the provision of social justice or in the reproduction of injustice. In this context, creative drama trainer should have an improved attitude on social justice. At this point, it is important to determine the social justice attitudes of creative drama trainers who implement creative drama practices. In this research, it was aimed to determine whether creative drama trainers differed in terms of social justice attitudes and various variables. In the study designed in the descriptive screening model, data were collected from sixty-five creative drama trainers by the "Social Justice Attitude Scale" adapted by Cirk (2015). The collected data were analyzed by SPSS package program. According to the results of the analysis, the social justice attitudes of creative drama trainers differ according to sex, but they do not differ significantly according to age, education level, graduation area and social injustice situation. It is suggested that the concept of social justice should be studied in different areas, especially in teacher training, and education in struggle with social injustices should be used as a tool
\end{abstract}

* Bu çalışma 20-23 Kasım 2018 tarihinde düzenlenen 28. Uluslararası Eğitimde Yaratıcı Drama Kongresi’nde bildiri olarak sunulmuştur.

1 Dr., Ankara Üniversitesi Eğitim Bilimleri Fakültesi, E-posta: skelesoglu1907@gmail.com.

2 Dr., Trakya Üniversitesi Eğitim Fakültesi, E-posta: ihsanmetinnam@gmail.com. 


\section{Giriş}

Sosyal adalet, toplumsal yaşamı yalnızca ekonomik sistemin değişkenlerine, gereksinimlerine bağlı olarak düzenlemek yerine, insanların ortak iyiliğini, adaleti sağlayacak biçimde düzenlemek olarak tanımlanabilir. Bell (1997, s.3'ten aktaran; Sunal, 2011, s.285), kaynakların eşit dağıtıldığ1 ve bütün üyeleri bedensel, psikolojik ve sosyal açıdan güvende olan bir toplumun adil olduğunu belirtmiştir. Rawls ise ekonomik kurumların "toplumsal adalete” tabi kılınmasına ilişkin görüşler öne sürer. Adaletin sağlanması için yalnız "herkes için geçerli eşit temel özgürlükler” yeterli değildir, toplumsal ve ekonomik eşitsizliklerin "en az avantajlı olana en büyük yarar sağlayacak" biçimde düzeltilmesi gerekmektedir (Rawls, 2001, s.133'den aktaran; Koray, 2007). Buradan yola çıkarak toplumsal adaleti sağlamak için ekonomik haklar kadar temel hak ve özgürlüklerin de güvence altına alınmasının önemli olduğu ifade edilebilir. Çünkü bir toplumun adalet temelinde organize olabilmesi için ekonomik anlamda eşit bir dağıtımın yanında, o toplumda yaşayan insanların özgürlükler ve haklar açısından da eşitliğin, adaletin olduğunu hissetmesi gerekmektedir. Böyle bir toplum da ancak birbirinin sorunlarına duyarlı ve adalet duygusu gelişmiş yurttaşların yetiştirilmesiyle oluşturulabilir. Adalet duygusu gelişmiş yurttaşların yetiştirilmesi ise özellikle eğitim sürecinin adaleti inşa etmeye dönük bir bakış açısıyla sürdürülmesine bağlıdır.

Eğitim alanındaki adaletsizliklere yönelik çalışmalar genel olarak "Eğitimde Sosyal Adalet" başlığı altında ele alınmaktadır. "Sosyal adalet odaklı eğitim araştırmaları, eğitimi oluşturan bütün bileşenleri hedeflemekte, bu bileşenler yoluyla var olan güç ilişkilerine dönük farkındalık yaratma, bu güç ilişkilerine müdahale etme becerisi kazandırma ve sonunda bu güç ilişkilerini değiştirerek daha adil bir toplum yaratma amacıyla yürütülmektedir" (Metinnam, 2017). Bu tür çalışmaların gerçekleştirilebilmesi için adaletsizliğin tarafı olan, çatışma yaşayan, mağduru olan insanların doğrudan bir araya getirilmesi gerekir. "Bu yüzden sosyal adalet çalışmalarının, toplumun farklı kesimlerini bir araya getiren, adaletle ilgili sorunların tartışıldığı ve bir araya gelen insanların aralarındaki etkileşime ilişkisel bakabildikleri ortamlarda gerçekleştirilmesinin daha etkili sonuçlar verdiği söylenebilir. Bu yüzden, sosyal adalet çalışmalarının insanların bir araya getirildiği etkileşimli çalışmalar olması gerekir. Çünkü eğitimde adalet düşüncesi, katılımcı bir tartışma ve karar verme sürecine odaklanma ile daha da ilgilidir" (Metinnam, 2017). Eğitimdeki güncel yaklaşımlar katılımcıları merkeze alan uygulamaların etkililiğini ön plana çıkartmaktadır. Özellikle yaratıcı drama gibi sosyal duyarlık yaratmayı, demokratik tutum kazandırmayı, yaratıcı ve eleştirel düşünme becerisini geliştirmeyi (Adıgüzel, 2018) hedefleyen yöntemlerin işe koşulması adalet kavramının çok boyutlu sorgulanabileceği ve günlük yaşamla ilişkisinin kurulabileceği eğitim ortamlarının oluşmasını sağlayacaktır. Yaratıcı dramanın insanın sosyal adalet algısının geliştirilmesinde etkili bir yaklaşım olarak görülmesinin bir diğer nedeni, sosyal adalete ilişkin kavramları ve sosyal adalet kültürünü daha derinlemesine anlaşılması için canlandırma, diyalog ve keşfetme yoluyla sunmasıdır (Teoh, 2012, s.6'dan akt; Metinnam 2017). Bu süreçlerde, sosyal adaletle ilgili konular uygulama süreçlerine dâhil edilerek tartışılabilir. Ancak, sosyal adaletin tartışıldığı temas alanlarının oluşturulmasında yöntemin etkililiği kadar eğitmenin yöntemi kullanırken takındığı tutum ve ele alınan konuya ilişkin birikimi de önem taşımaktadır (Metinnam, 2017). Yaratıcı drama eğitmeni drama sürecinin temellerinden ve önemli ögelerinden biridir (Adıgüzel, 2018).

Yaratıcı drama, katılımcı merkezli bir disiplin ve öğretim yöntemi olsa da eğitmenin süreç üzerindeki etkisi yadsınamaz. Yaratıcı drama eğitmeninin uyması gereken kurallar arasında 
"katılımcıların kişiliklerine dönük eleştirilerde bulunmama, katılımcılara önyargısız, hoşgörülü ve eşit mesafede olma, demokratik davranma, onları yargılamama” (Adıgüzel, 2018) gibi eğitmenin adaleti sağlayıcı yönüne dönük vurgular bulunmaktadır. Katılımcının özgür bir biçimde hareket edebilmesi ve yaratıcı ifade biçimlerini ortaya koyabilmesi için kendini güvende hissetmesi gerekir. Katılımcının kendini güvende hissetmesi ise eğitmenin atölye süreçlerindeki tutumlarıyla doğrudan ilgilidir. Eğer eğitmen, bütün katılımcılara eşit mesafede ve adaletli bir tutuma sahipse katılımcılar kendilerini daha rahat ve güvende hissedebilirler. Bu bağlamda, özellikle eğitmenin sosyal adalete ilişkin güçlü bir tutuma sahip olması gerektiği söylenebilir. Çünkü yaratıcı drama süreçleri boyunca eğitmen alanla ilgili yönlendirici rolünün yanında aynı zamanda grup içerisinde adalet dağıtan kişi rolünü de üstlenir.

30 Mart 2011 tarihinde Çağdaş Drama Derneği ve BAG Spiel Und Theater e.V. (Almanya Federal Oyun ve Tiyatro Üst Birliği) ortak çalışması ${ }^{3}$ olan "Yaratıcı Drama Eğitmenleri ve Tiyatro Pedagoglarının Davranış ve Tutumuna İlişkin Etik Bildirge (Sözleşme)" ilan edilmiştir. Bu bildirge (sözleşme), yaratıcı drama alanında çalışan eğitmenlerin mesleki bağlamda uyması gereken etik kuralları düzenleyen bir metindir. Bildirgenin (sözleşmenin) kamuoyu ile paylaşıldığı tarihten sonra Çağdaş Drama Derneği bünyesindeki eğitmenlerin hepsi sözü edilen etik bildirgeyi imzalayarak bildirgedeki etik kurallara sadık kalacaklarını taahhüt etmişlerdir. Bu sözleşmede, yaratıcı drama eğitmeninin adaleti sağlayıcı konumu özellikle vurgulanmıştır. Buna karşın, alan yazında yaratıcı drama eğitmenlerinin sosyal adalet tutumlarını incelemeye dönük bir çalışmaya rastlanmamıştır. $\mathrm{Bu}$ araştırmada yaratıcı drama eğitmenlerinin sosyal adalet tutumlarının belirlenmesi ve tutumlarının farklı değişkenler açısından farklılaşıp farklılaşmadığı belirlenmeye çalışılmıştır.

Araştırmada;

Yaratıcı drama eğitmenlerinin sosyal adalet tutumları;

a. Cinsiyete,

b. Yaşa,

c. Mezuniyet alanına,

d. Öğrenim düzeyine ve

e. Sosyal adaletsizliğe uğrama durumuna, göre farklılaşmakta mıdır? sorularına yanıt aranmıştır.

\section{Yöntem}

\section{Araştırma Modeli}

$\mathrm{Bu}$ araştırma, yaratıcı drama liderlerinin var olan sosyal adalet tutumlarının belirlenmesini amaçladığ 1 için betimsel bir araştırmadır ve ilişkisel tarama modeline göre modellenmiştir. Tarama modelleri, geçmişte ya da güncel olan bir durumu olduğu şekliyle betimlemeyi amaçlayan araştırma yaklaşımlarıdır (Karasar, 2004, s.77).

4 Bildiride emeği geçen uzmanlar; Ömer Adigüzel (TR), Romi Domkowsky (GER), Ute Handwerg (GER), Klaus Hoffmann (GER), Gerd Koch (GER), Sinah Marx (GER), Inci San (TR). 


\section{Çalışma Grubu}

Araştırmanın çalışma grubunu Çağdaş Drama Derneği Liderlik/Eğitmenlik Programını tamamlamış ve yaratıcı drama eğitmeni olarak çalışmakta olan bireyler oluşturmaktadır. Ölçme araçlarının uygulandığı katılımcılar, "yaratıcı drama eğitmeni olmak" durumu dikkate alınarak amaçlı örnekleme yoluyla belirlenmiştir. $\mathrm{Bu}$ örnekleme tekniğinde, araştırmanın amaçları doğrultusunda bir evrenin temsilci bir örneği yerine, amaçlı olarak grup belirlenmiştir. Başka bir ifade ile amaçlı örnekleme, evrenin soruna en uygun bir kesimini gözlem konusu yapmak demektir (Sencer, 1989, s.386). Amaçlı örneklemde araştırmacı, evrenle ilgili daha önceki kuramsal bilgilere, kendi bilgilerine ve araştırmanın özel amacına dayanarak bir örneklem belirlemektedir (Fraenkel ve Wallen, 1993, s. 87). Bu araştırmada, araştırma grubunun belirlenmesinde amaçlı örnekleme çeşitlerinden, maksimum çeşitlilik yöntemi benimsenmiş ve bu bağlamda evrenin temsili göz önünde bulundurularak, bireylerin seçilmesinde "yaratıcı drama eğitmeni olmak" dikkate alınarak katılımcılar seçilmiş ve ölçme araçları bu bireylere uygulanmıştır. Bu örnekleme yönteminin evren değerleri hakkında önemli ipuçları vereceği düşünülmektedir (Büyüköztürk, Kılıç Çakmak, Akgün, Karadeniz ve Demirel, 2008, s.79).

Araştırma kapsamında kullanılan veri toplama araçları 65 katılımcıya uygulanmıştır. Veri analizleri öncesi, katılımcıların veri toplama araçlarına verdikleri yanıtlar gözden geçirilmiştir. $\mathrm{Bu}$ inceleme sonucunda, ölçek maddelerini boş bırakan katılımcıya rastlanmamıştır. Araştırmaya katılan bireylerin çeşitli değişkenlere göre dağ 1 lımı Tablo 1'de sunulmuştur.

Tablo 1. Çalışma Grubu

\begin{tabular}{llll}
\hline Değişken & Düzey & $\mathrm{n}$ & $\%$ \\
\hline \multirow{2}{*}{ Cinsiyet } & Kadın & 44 & 67,7 \\
\cline { 2 - 4 } & Erkek & 21 & 32,3 \\
\hline \multirow{2}{*}{ Yaş } & $20-29$ & 17 & 26,2 \\
\cline { 2 - 4 } & $30-39$ & 31 & 47,7 \\
\hline \multirow{2}{*}{ Öğrenim Düzeyi } & $40+$ & 17 & 26,2 \\
\hline \multirow{2}{*}{ Mezuniyet Alanı } & Lisans & 23 & 35,4 \\
\cline { 2 - 4 } & Lisansüstü & 42 & 64,6 \\
\hline Adaletsizliğe Uğrama & Eğitim Fakültesi & 49 & 75,4 \\
\cline { 2 - 4 } Durumu & Diğer & 16 & 24,6 \\
\hline
\end{tabular}

Araştırmaya katılan yaratıcı drama eğitmenlerinin \%67,7'si kadın iken \%32,3’ü erkektir. Yaratıcı drama eğitmenlik programını bitiren kişilerin çoğu kadın olduğu için çalışma grubunda bu oranın normal olduğu düşünülmektedir. Araştırmaya katılan eğitmenlerin \%17'si 20-29 yaş arasında iken \%31'i 30-39 yaş arasında diğer \%17'si ise 40 yaş üzerindedir. Katılımcıların \%35'i lisans eğitimi mezunu iken \%64,6'sı yüksek lisans mezunudur. Yaratıcı drama, Ankara ve Anadolu Üniversitelerinde yüksek lisans programı olarak yürütülmektedir. Katılımcıların bu lisansüstü eğitimi tamamlamış bireyler olma olasılığını bulunmaktadır. Bu durum katılımcıların eğitim alanından mezun olmaları ile paralellik göstermektedir. Katılımcıların \%80'i sosyal adaletsizliğe uğradıklarını düşünürken \%20'si herhangi bir sosyal adaletsizlik durumuyla karşılaşmadığını ifade etmiştir. 


\section{Veri Toplama Araçları}

Araştırmada veriler, Torres-Harding (2012) tarafından geliştirilen ve Cırık (2015) tarafından Türkçe uyarlaması yapılan Sosyal Adalet Ölçeği (Social Justice Scale) ile toplanmıştır. İlgili tutum ölçeği iki bölümden oluşmaktadır. Ölçeğin birinci bölümünde yaratıcı drama liderlerine ait cinsiyet, öğrenim düzeyi, mezuniyet alanı, kıdem ve sosyal adaletsizliğe uğrama durumlarına ilişkin veriler istenmiştir. Ölçeğin ikinci bölümünde sosyal adalet tutumlarını ölçen 24 madde dört boyut altında toplanmaktadır. Bu 24 madde toplam varyansın \%73,529'unu açıklamaktadır. Her bir madde 1'den 7'ye kadar puanlanabilmektedir. Ölçekten alınabilecek en yüksek puan 120, en düşük puan ise 24'dür. Doğrulayıcı faktör analizi sonuçlarına göre ölçeğin dört faktörlü yapısı doğrulanmıştır. Güvenirlik çalışmasında hesaplanan iç tutarlık değeri (.85) ölçeğin güvenilir olduğunu göstermiştir.

Araştırma kapsamında ölçeğin geçerlik ve güvenirlik çalışması yapılmıştır. KMO ve Barlett testi sonuçları $\left(\mathrm{KMO}=0.85 ; \mathrm{x}^{2}=1434,039 ; \mathrm{p}=0.00\right)$ veri grubunun faktör analizine uygun olduğunu göstermiştir. Veriler üzerinde Temel Bileşenler Analizi yapılmıştır. Temel Bileşenler Analizi sonunda ölçeğin 4 faktörlü bir yapıda olduğu ve açıkladığı toplam varyansin 73.72 olduğu bulunmuştur. Ölçeğin analiz sonucunda elde edilen 4 faktörlü yapısına ilişkin sonuçlar Tablo 2'de sunulmaktadır.

Tablo 2. Faktör Analizi Sonuçları

\begin{tabular}{|c|c|c|c|c|}
\hline \multirow[b]{2}{*}{ Madde No } & \multicolumn{4}{|c|}{ Faktörler } \\
\hline & İnanç & Diğer Bireylerle İşbirliği & Başkalarını Etkileme & Bireysel Destek Verme \\
\hline 1 & ,646 & & & \\
\hline 2 &, 854 & & & \\
\hline 3 & ,526 & & & \\
\hline 4 & 911 & & & \\
\hline 5 & & & & ,804 \\
\hline 6 &, 765 & & & \\
\hline 7 & 826 & & & \\
\hline 8 & ,906 & & & \\
\hline 9 & & & & ,784 \\
\hline 10 & ,906 & & & \\
\hline 11 & ,877 & & & \\
\hline 12 & & & 803 & \\
\hline 13 & & & & ,718 \\
\hline 14 & & & 845 & \\
\hline 15 & & & ,633 & \\
\hline 16 & & & ,795 & \\
\hline 17 & & ,860 & & \\
\hline 18 & & ,896 & & \\
\hline 19 & & ,905 & & \\
\hline 20 & & ,856 & & \\
\hline 21 & & & & ,782 \\
\hline 22 & ,734 & & & \\
\hline 23 & 670 & & & \\
\hline 24 & 849 & & & \\
\hline
\end{tabular}


Sosyal Adalet Tutum Ölçeği; İnanç, Diğer Bireylerle İşbirliği, Başkalarını Etkileme ve Bireysel Destek olmak üzere toplam 4 faktörden ve 24 maddeden oluşmaktadır. Madde yük değerleri .67 ile .91 arasında değişmektedir.

\section{Verilerin Toplanmasi}

Çağdaş Drama Derneği’nin merkezi Ankara'da bulunmaktadır. Derneğin eğitmenlik programını tamamlamış kişiler Türkiye'nin dört bir yanında görev yapmaktadırlar. Yaratıcı drama eğitmenliği MEB'e bağlı bir okulda usta öğretici statüsünde olabileceği gibi çeşitli özel kurslarda da yapılmaktadır. Bu nedenle yaratıcı drama eğitmenlerine ulaşmak ve eğitmenlerinden veri toplamak için kartopu modeli kullanılmıştır. Dernek eğitmenlerinden bazılarına ulaşılarak ölçme aracını tanıdıkları eğitmenlerle paylaşmaları istenmiştir. Veri toplama süreci çevrim içi veri toplama araçları kullanılarak Ağustos - Ekim 2017 tarihleri arasında gerçekleştirilmiştir.

\section{Verilerin Analizi}

Sosyal Adalet Tutum Ölçeği ile toplanan veriler SPSS paket programı kullanılarak analiz edilmiştir. Yaratıcı drama eğitmenlerinin demografik özelliklerinin analizinde frekans ve yüzde dağılımı kullanılmıştır. Sosyal adalet tutumlarının demografik değişkenlere göre farklılaşıp farklılaşmadığını belirlemek amacıyla ilişkisiz örneklemler $t$ testi ve ilişkisiz örneklemler için tek yönlü varyans analizi (ANOVA) yapılmıştır. Verilerin analizinde güven aralığ $1 \% 95$ olarak alınmıştır.

\section{Bulgular}

Bu bölümde araştırmanın amaçları doğrultusunda elde edilen bulgular ve bulgulara yönelik yorumlara yer verilmiştir.

\section{Cinsiyet Değişkeni Açısından Sosyal Adalet Tutum Ölçeği Puanlarına İlişskin Bulgular}

Yaratıcı drama eğitmenlerinin Sosyal Adalet Tutum Ölçeğinden aldıkları puanların cinsiyet değişkeni açısından farklılaşıp farklılaşmadığına ilişkin ilişkisiz örneklemler t testi sonuçları Tablo 3'te sunulmuştur.

Tablo 3. Katılımcıların SATÖ Puanlarının Cinsiyete Göre t-Testi Sonuçları

\begin{tabular}{ccccccc}
\hline Cinsiyet & $\mathrm{N}$ & $\mathrm{X}$ & $\mathrm{S}$ & $\mathrm{t}$ & $\mathrm{Sd}$ & $\mathrm{p}$ \\
\hline Kadın & 44 & 6,29 &, 38430 & 3,423 & 63 &, 001 \\
\hline Erkek & 21 & 5,74 &, 93466 & & & \\
\hline
\end{tabular}

Analiz sonuçlarına göre yaratıcı drama eğitmenlerinin Sosyal Adalet Tutum Ölçeği ortalama puanları cinsiyete göre anlamlı farklılık göstermektedir $[\mathrm{t}(63)=3,423, \mathrm{p}<.001]$. Kadın eğitmenlerin ölçekten aldıkları ortalama puan $(X=6,29)$ erkek eğitmenlerin aldıkları ortalama puandan $(X=5,74)$ daha yüksektir. Bu bulgu, kadın eğitmenlerin sosyal adalet tutumlarının erkek eğitmenlerden anlamlı derecede daha olumlu olduğunu göstermektedir.

\section{Yaş Değişkeni Açısından Sosyal Adalet Tutum Ölçeği Puanlarına İlişkin Bulgular}

Yaratıcı drama eğitmenlerinin yaş değişkeni açısından Sosyal Adalet Tutum Ölçeği puanların anlamlı derecede değişip değişmediğini belirlemek için yapılan ANOVA testi sonuçları Tablo 4 'te sunulmuştur. 
Tablo 4. Katılımcıların SATÖ Puanlarının Yaşa Göre ANOVA Sonuçları

\begin{tabular}{ccccccc}
\hline $\begin{array}{c}\text { Varyansın } \\
\text { Kaynağ1 }\end{array}$ & $\begin{array}{c}\text { Kareler } \\
\text { Toplamı }\end{array}$ & sd & $\begin{array}{c}\text { Kareler } \\
\text { Ortalamas1 }\end{array}$ & F & p & Anlamlı Fark \\
\hline Gruplararas1 &, 989 & 2 &, 495 & 1,125 &, 331 & \\
\hline Gruplar içi & 27,263 & 62 &, 440 & & & \\
\hline Toplam & 28,252 & & & & \\
\hline
\end{tabular}

Analiz sonuçlarına göre yaratıcı drama eğitmenlerinin Sosyal Adalet Tutum Ölçeği ortalama puanları yaşa göre anlamlı farklılık göstermemektedir $[\mathrm{F}(2-62)=1,125, \mathrm{p}>.001]$. 20-29 yaş arası eğitmenlerin ölçekten aldıkları ortalama puan $(X=5,914)$; 30-39 yaş arası eğitmenlerin ortalama puanları $(X=6,21)$ ve 40 yaş üstü eğitmenlerin ortalama puanları $(X=6,15)$ 'dir. Ortalamalar arasındaki sayısal farklar anlamlı değildir. Yaş değişkenine göre eğitmenlerin ortalama puanları Tablo 5'de sunulmuştur.

Tablo 5. Yaratıcı Drama Eğitmenlerin SATÖ Ortalama Puanlarının Yaş Değişkenine Göre Ortalama Puanlart ve Standart Sapmalart

\begin{tabular}{|c|c|c|c|c|c|}
\hline Yaş & $\mathrm{N}$ & $\mathrm{X}$ & $\mathrm{Ss}$ & Minimum & Maksimum \\
\hline 20-29 Yaş & 17 & 5,91 & 1,07 & 1,96 & 6,71 \\
\hline 30-39 Yaş & 31 & 6,20 &, 437 & 4,92 & 7 \\
\hline 40 ve üzeri & 17 & 6,15 &, 439 & 5,58 & 7 \\
\hline Toplam & 65 & 6,11 &, 664 & 1,96 & 7 \\
\hline
\end{tabular}

\section{Öğrenim Düzeyi Değişkeni Açısından Sosyal Adalet Tutum Ölçeği Puanlarına İlişkin Bulgular}

Yaratıcı drama eğitmenlerinin Sosyal Adalet Tutum Ölçeğinden aldıkları puanların öğrenim düzeyi değişkeni açısından farklılaşıp farklılaşmadığına ilişkin ilişkisiz örneklemler $t$ testi sonuçları Tablo 6'da sunulmuştur.

Tablo 6. Katılımcıların SATÖ Puanlarının Öğrenim Düzeyine Göre t-Testi Sonuçları

\begin{tabular}{ccccccc}
\hline Düzey & N & X & S & t & Sd & p \\
\hline Lisans & 23 & 6,06 &, 997 &, 487 & 63 &, 628 \\
\hline Lisansüstü & 42 & 6,14 &, 391 & & & \\
\hline
\end{tabular}

Analiz sonuçlarına göre yaratıcı drama eğitmenlerinin Sosyal Adalet Tutum Ölçeği ortalama puanları öğrenim düzeyine göre anlamlı farklılık göstermemektedir [ $\mathrm{t}(63)=, 487, \mathrm{p}<.001]$. Lisans mezunu eğitmenlerin ölçekten aldıkları ortalama puan $(X=6,06)$ iken lisansüstü eğitim almış eğitmenlerin aldıkları ortalama puanları $(X=6,14)$ 'dür.

\section{Mezuniyet Alanı Değişkeni Açısından Sosyal Adalet Tutum Ölçeği Puanlarına İlişkin Bulgular}

Yaratıcı drama eğitmenlerinin bir bölümü Eğitim Fakültesi mezunu iken diğer bir bölümü farklı lisans ve lisansüstü eğitimleri tamamlamışlardır. Eğitmenlerin Sosyal Adalet Tutum Ölçeğinden aldıkları puanların eğitim fakültesi mezunu olup olmama durumuna göre farklılaşıp farklılaşmadığına ilişkin ilişkisiz örneklemler t testi sonuçları Tablo 7'de sunulmuştur. 
Tablo 7. Katılımcıların SATÖ Puanlarının Öğrenim Alanlarına Göre t-Testi Sonuçları

\begin{tabular}{|c|c|c|c|c|c|c|}
\hline Alan & $\mathrm{N}$ & $\mathrm{X}$ & $\mathrm{S}$ & $\mathrm{t}$ & $\mathrm{Sd}$ & $\mathrm{p}$ \\
\hline $\begin{array}{c}\text { Eğitim } \\
\text { Fakültesi }\end{array}$ & 49 & 6,087 &, 701 &, 642 & 63 &, 523 \\
\hline Diğer & 16 & 6,21 &, 542 & & & \\
\hline
\end{tabular}

Analiz sonuçlarına göre yaratıcı drama eğitmenlerinin Sosyal Adalet Tutum Ölçeği ortalama puanları öğrenim alanlarına göre anlamlı farklılık göstermemektedir $[\mathrm{t}(63)=, 642, \mathrm{p}<.001]$. Eğitim fakültesi mezunu eğitmenlerin ortalama puanları $(X=6,087)$ iken eğitim fakültesi mezunu olmayanların ortalama puanları $(X=6,21)$ 'dir. Bu bulguya göre Eğitim Fakültesi mezunu olup olmamak yaratıcı drama eğitmenlerinin sosyal adalet tutumlarını etkilememektedir.

\section{Sosyal Adaletsizliğe Uğrama Durumu Açısından Sosyal Adalet Tutum Ölçeği Puanlarına İlişkin Bulgular}

Yaratıcı drama eğitmenlerinin büyük bir bölümü yaşantıları boyunca en az bir kere sosyal adaletsizlik durumu ile karşılaştı̆̆ını ifade etmişlerdir. Bu açıdan sosyal adaletsizliğe uğrayan ve uğramayan eğitmenlerin Sosyal Adalet Tutumlarının farklılaşıp farklılaşmadığına ilişkin ilişkisiz örneklemler t testi yapılmıştır. Test sonuçları Tablo 8'de sunulmuştur.

Tablo 8. Katılımcıların SATÖ Puanlarının Sosyal Adaletsizliğe Uğrama Durumuna Göre t-Testi Sonuçları

\begin{tabular}{ccccccc}
\hline Alan & $\mathrm{N}$ & $\mathrm{X}$ & $\mathrm{S}$ & $\mathrm{t}$ & $\mathrm{Sd}$ & $\mathrm{p}$ \\
\hline Uğradım & 52 & 6,13 &, 412 &, 244 & 63 &, 811 \\
\hline Uğramadım & 13 & 6,04 & 1,27 & & & \\
\hline
\end{tabular}

Analiz sonuçlarına göre yaratıcı drama eğitmenlerinin Sosyal Adalet Tutum Ölçeği ortalama puanları öğrenim alanlarına göre anlamlı farklılık göstermemektedir $[\mathrm{t}(63)=, 244, \mathrm{p}>.001]$. Sosyal adaletsizliğe uğradığını düşünen eğitmenlerin ortalaması $(X=6,13)$ iken uğramadığını düşünen eğitmenlerin ortalaması $(X=6,04)$ 'dür. Eğitmenlerin ortalamaları karşılaştırıldığında yüksek bir tutuma sahip oldukları görülmektedir. Eğitmenler yaşantılarında sosyal adaletsizliğe uğramış olsalar da olmasalar da eğitmenlerin sosyal adalete ilişkin farkındalıklarının yüksek olduğu düşünülmektedir.

\section{Tartışma, Sonuç ve Öneriler}

Sosyal adalet Türkiye'de çok fazla tanınmayan ve üzerine çok fazla akademik çalışma yapılmamış bir alandır. Başta Amerika Birleşik Devletleri gibi yoğun göçmen nüfusa sahip Avrupa ülkelerinde yapılan eğitimde sosyal adalet çalışmalarında, ülkeyi oluşturan farklı kimliklere, sınıfsal konumlara sahip bileşenler arasında adaleti sağlamanın gerekliliğine yönelik yoğun bir vurguyla karşılaşılmaktadır. Türkiye'de adaletle ilgili yapılan çalışmaların yoğunlukla örgütsel adalet ve iş tatmini ilişkisi ekseninde ele alındığı (Yürür, 2008; Özer ve Urtekin, 2007), yoğunlukla eğitim dış1 alanlarda gerçekleştirildiği görülmektedir. Eğitim alanında gerçekleştirilen çalışmaların da adaleti genellikle örgütsel adalet bağlamında ele aldığı ifade edilebilir. Bu çalışmalar içerisinde örgütsel adaleti iş doyumu (Töremen ve Tan, 2010), örgütsel güven ve vatandaşlık davranışları (Polat ve Celep, 2008), doğrudan öğretmenlerin örgütsel adalet algıları (Y1lmaz, 2010) ve öğretmenlerin 
örgütsel adalet algıları ve örgütsel sessizlik düzeyleri arasındaki ilişki bağlamında ele alanlar bulunmaktadır. Bu çalışmada, örgütsel adalet yerine bir demokratik kitle örgütü olan Gençlik Kulübü ve Çağdaş Drama Derneği eğitmenlerinin doğrudan sosyal adalet tutumları belirlenmeye çalışılmıştır. Demokratik bir toplum inşasını amaçlayan ve bu amaçla eğitimi etkili bir biçimde kullanan yaratıcı drama, toplumdaki tüm adaletsizliklerin ortadan kaldırılmasını amaçlamaktadır. $\mathrm{Bu}$ amaca yönelik olarak yaratıcı drama eğitimi alan ve veren kişilerin sosyal adalet tutumlarının yüksek olması beklenmektedir.

Yapılan araştırma sonuçlarına göre yaratıcı drama eğitmenlerinin sosyal adalet tutumları yüksektir. Bu tutumlar yaşa, öğretim düzeyine, mezun olunan alana, sosyal adaletsizliğe uğrama durumlarına göre anlamlı bir biçimde değişmemektedir. Buna karşın cinsiyet değişkeni açısından yaratıcı drama eğitmenlerinin ortalama puanları arasında anlamlı bir fark bulunmaktadır. Kadın eğitmenlerin ortalama puanları erkek eğitmene göre anlamlı derecede yüksektir. $\mathrm{Bu}$ sonucun; kadının Türkiye toplumunda erkeğe göre daha fazla adaletsizlikle karşı karşıya kalmasından kaynaklanabileceği düşünülebilir. Eğitim alanında kadınların adalet tutumlarını doğrudan ele alan çalışmalar bulunmasa da "cam tavan sendromu"ndan yola çıkılarak iş dünyasındaki kadınların adalet algıları üzerine yapılmış çalışmalar kadınların iş yerlerinde karşılaştıkları engellerden dolayı daha fazla adaletsizliğe uğradıklarını ortaya koymaktadır (Özyer ve Azizoğlu, 2014; Örücü ve Kılıç ve Kılıç, 2007; Mizrahi ve Aracı, 2010). Her ne kadar arada anlamlı bir fark oluşsa bile her iki grubun da ortalamaların yüksek olduğuna da dikkat edilmelidir.

Sürdürülebilir Yönetim Göstergeleri (Sustainable Governance Indicators, 2018) verilerine göre Türkiye sosyal adalet konusunda iyi bir karneye sahip değildir. Yurttaşlar arasında sosyal adaletin sağlanmasına yönelik olarak başta eğitim olmak üzere farklı alanlarda çalışmaların yapılması gerekmektedir. Özellikle öğretmen eğitiminde sosyal adalet çalışmalarının yapılması ve belirlenebilecek sorunların çözümüne yönelik politikaların geliştirilmesi, bu politikaların da toplumun her kesiminin katılımıyla yaşama geçirilmesi önerilmektedir. Böylece toplumda oluşabilecek sosyal adaletsizliklerin önü kapatılabilir ve yurttaşlar arasındaki refah düzeyi yükselebilir. 


\section{Kaynakça}

Adıgüzel, Ö. (2018). Eğitimde yaratıcı drama. İstanbul: Yapı Kredi Yayınları.

Büyüköztürk, Ş., Çakmak, E. K., Akgün, Ö. E., Karadeniz, Ş., \& Demirel, F. (2008). Bilimsel araştırma yöntemleri. Ankara: Pegem.

Cirık, İ. (2015). Psychometric characteristics of the social justice scale's turkish form and a structural equation modeling. Eurasian Journal of Educational Research 61, 23-44.

Fraenkel, J. R., \& Wallen, N. E.(1993). How to design and evaluate research in education. New York: McGraw-Hill Education.

Karasar, N. (2004). Bilimsel araştırma yöntemleri. Ankara: Nobel.

Koray, M. (2007). Sosyal politikanın anlamını ve işlevini tartışmak. Çalışma ve Toplum, 4, 19-55.

Metinnam, İ. (2017). Yaratıcı dramayla kültürel temas alanları oluşturmak: Sanat eğitiminde katılımcı bir eylem araştırması örneği (Yayımlanmamış Doktora Tezi). Ankara Üniversitesi, Ankara.

Mızrahi, R ve Aracı, H. (2010). Kadın Yöneticiler ve Cam Tavan Sendromu Üzerine Bir Araştırma, Organizasyon ve Yönetim Bilimleri Dergisi, 2(1), 150-155.

Örücü, E. ve Kılıç, R. Ve Kılıç, T. (2007). Cam Tavan Sendromu ve kadınların üst düzey yönetici pozisyonuna yükselmelerindeki engeller: Balıkesir ili örneği, Yönetim ve Ekonomi Dergisi, 14(2), 117-135.

Özer, P.S. ve Urtekin, G. E. (2007). Örgütsel adalet algısı boyutları ve iş doyumu ilişkisi üzerine bir araştırma, Erciyes Üniversitesi İktisadi ve İdari Bilimler Fakültesi Dergisi, 28, 107-125.

Özyer, K. ve Azizoğlu, Ö. (2014). İş hayatında kadınların önündeki cam tavan engelleri ile algılanan örgütsel adalet arasındaki ilişki, Abant İzzet Baysal Üniversitesi İktisadi ve İdari Bilimler Fakültesi Ekonomik ve Sosyal Araştırmalar Dergisi, 10(10), 95-106.

Polat, S. ve Celep, C. (2008). Ortaöğretim öğretmenlerinin örgütsel adalet, örgütsel güven, örgütsel vatandaşlık davranışlarına ilişkin algıları. Kuram ve Uygulamada Eğitim Yönetimi, 54, 307-331.

Ryan, A. (2015). John Rawls. Q. Skinner (Ed.). Çağdaş temel kuramlar içinde İstanbul: İletişim Yayınları.

Sunal, O. (2011). Sosyal politika: Sosyal adalet açısından kuramsal bir değerlendirme, Siyasal Bilgiler Fakültesi Dergisi, 66(3), 283-305.

Sustainable Governance Indicators (2018). http://www.sgi-network.org/2017/Policy_Performance adresinden 1.3.2018 tarihinde indirilmiştir.

Töremen, F. ve Çan, T. (2010). Eğitim örgütlerinde adalet: Kavramsal bir çözümleme, Dicle Üniversitesi Ziya Gökalp Eğitim Fakültesi Dergisi, 14, 58-70.

Yılmaz, K. (2010). Devlet ortaöğretim okullarında görev yapan öğretmenlerin örgütsel adalet algıları, Kuram ve Uygulamada Eğitim Bilimleri, 10(1), 579-616.

Yürür, S. (2008). Örgütsel adalet ile iş tatmini ve çalışanların bireysel özellikleri arasındaki ilişkilerin analizine yönelik bir araştırma, Süleyman Demirel Üniversitesi İktisadi ve İdari Bilimler Fakültesi Dergisi, 13(2), 295-312 


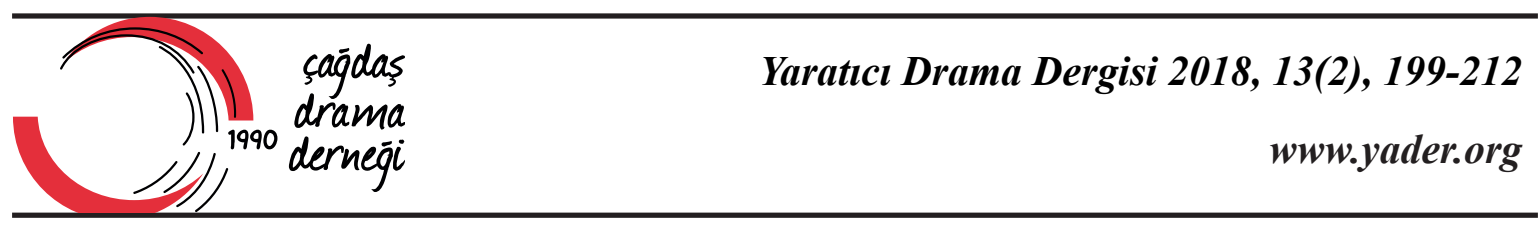

\section{İlkokula Devam Eden Kaynaştırma Öğrencilerinin Sınıf İçi Etkinliklere Katılım Düzeyine Yaratıcı Drama Yönteminin Etkisinin İncelenmesi}

Fatih Kıvanç Erdoğan'

Süleyman Arslantaş ${ }^{2}$

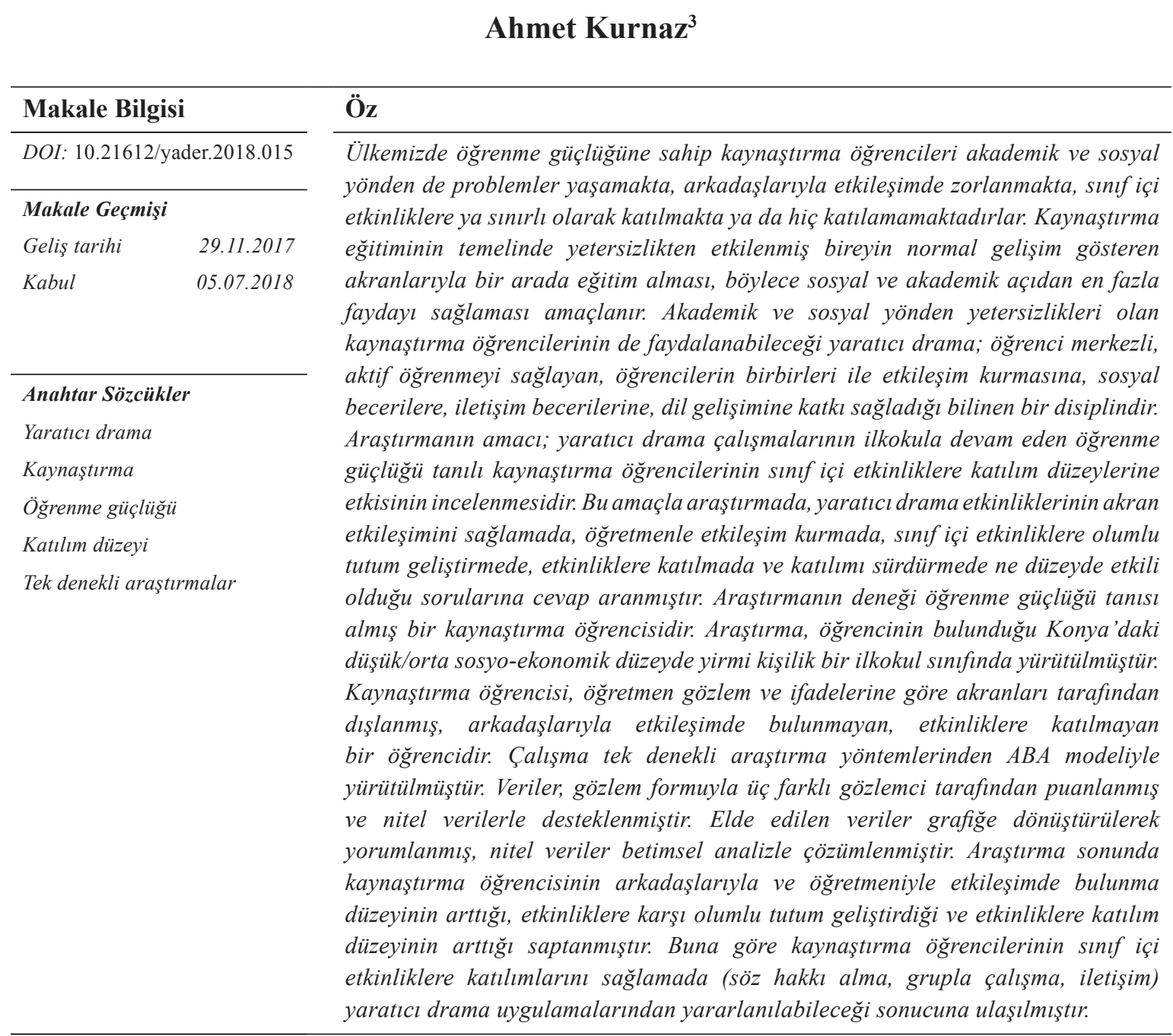

Öğretmen, AKD Kids anaokulu, E-posta: 94kivanc@gmail.com

2 Dr. Öğr. Üy., Necmettin Erbakan Üniversitesi, E-posta: gsarslantas@hotmail.com

3 Dr. Öğr. Üy., Necmettin Erbakan Üniversites, E-posta: ahkurnaz@hotmail.com 


\begin{tabular}{lr}
\hline Article Info \\
\hline DOI: $10.21612 /$ yader.2018.015 \\
\hline Article History & \\
Received & 29.11 .2017 \\
Accepted & 05.07 .2018
\end{tabular}

The Analysis of the Effect of Creative Drama Activities on Participation Levels of Elementary School Inclusive Students Diagnosed with a Learning Disability in Classroom Activities

Keywords

Creative drama

Inclusion

Learning disabilities

Level of participation

Single subject research

\section{Abstract}

In our country, inclusive students with intellectual disabilities and learning disabilities typically experience difficulties both socially and academically and have difficulty in interacting with their peers. They infrequently or never participate in classroom activities. Inclusive education is based on the principle that aims to educate individuals affected by disability along with their non-disabled peers on the same basis and to be helpful to them both socially and academically. Creative drama, from which inclusive students could benefit socially and academically, is a discipline based on a student-centered approach enabling active learning, helping students interact with each other, developing their social and communication skills and improving language developments as well. The purpose of this study is to investigate the effect of creative drama activities on participation levels of elementary school inclusive students diagnosed with a learning disability to classroom activities. Hence, answers to the following questions were sought: "To what extent are creative drama activities effective in maintaining peer relationships, interacting with the teacher, developing positive attitudes towards in-class activities, participating in the activities and maintaining involvement? The subject of this study is an inclusive student who has been diagnosed with a learning disability. The research has been conducted in an elementary school class of 20 pupils in a low/middle socio-economic setting in Konya, where the student lives. According to teacher observations and expressions, the inclusive student is a pupil excluded by his peers, not interacting with his friends and not participating in activities. One of the single-subject research designs, 'ABA pattern'was used in this study. The data were obtained by 3 different observers through observation forms and supported by the qualitative data. The data obtained were transformed into graphics and findings were interpreted. Qualitative data were analyzed through descriptive analysis. At the end of the research, it was determined that the level of interaction between the inclusive student and his peers and teacher increased, he developed a positive attitude towards activities and his levels of participation in activities increased. Accordingly, creative drama practices can be used to ensure that inclusive students participate in classroom activities (asking for permission to speak, working in groups, communication). 


\section{Giriş}

Türk Milli Eğitimin genel amaçlarının ikinci maddesinde ruh ve duygu bakımından dengeli ve sağlıklı, ilgi kabiliyetlerini geliştiren, birlikte iş görebilen, kendisi mutlu ve toplumu da mutlu kılacak bireyler yetiştirilmesinden söz edilmektedir (MEB 1973). Genel amaçlar doğrultusunda tüm çocukların birbiriyle uyumlu, saygı ve hoşgörü çerçevesinde ilişkiler kurması beklenilmektedir. $\mathrm{Bu}$ amaçlar özel gereksinimli bireyler için de ulaşılması gereken hayati amaçlardır. Özel gereksinimli birey, MEB Özel Eğitim Hizmetleri 31.05.2006 tarih ve 26184 sayılı Resmî Gazete yönetmeliğinde "çeşitli nedenlerle bireysel özellikleri ve eğitim yeterlikleri açısından akranlarından beklenilen düzeyde anlamlı farklılık gösteren birey” olarak tanımlanmıştır.

Ülkemizde tarama ve tanılamanın gelişmesi sonucunda özel eğitime gereksinimli bireylerin eğitim ortamlarındaki sayıları artmış, bu da beraberinde en az kısıtlayıcı ortamda sürdürülen kaynaştırma eğitiminde farklı ihtiyaçlar doğurmuştur. Kaynaştırma, özel gereksinimli öğrencinin genel eğitim okullarında normal gelişim gösteren akranlarıyla birlikte, gerektiğinde kendisine ve sınıf öğretmenine destek hizmetler sağlamak suretiyle öğretim görmesidir (Sucuoğlu ve Kargın 2006). Başka bir tanıma göre kaynaştırma; özel eğitim gerektiren bireylerin, yetersizliği olmayan akranları ile birlikte eğitim ve öğretimlerini resmi ve özel okul öncesi, ilköğretim, ortaöğretim ve yaygın eğitim kurumlarında sürdürmeleri esasına dayanan destek eğitim hizmetlerinin sağlandığ özel eğitim uygulamalarıdır (Batu ve Kırcaali-İftar, 2006). Kaynaştırma eğitiminde sınıf öğretmeni, sınıfta öğrenim gören öğrenciler, veliler ile destek eğitim öğretmeni bu sürecin dinamiklerindendir. Sınıf öğretmeninin kaynaştırmaya ilişkin olumlu tutumu ve yeterliliği eğitimin kalitesini büyük ölçüde etkiler. Kaynaştırmaya yönelik tutumlar, öğretmen yeterlilikleri, sınıfların fiziksel koşulları ve akran tutumları kaynaştırma öğrencilerinin var olan potansiyellerini ortaya koymada, ihtiyaçları olan eğitimin tamamını karşılamada olumsuzluklar yaratabilir.

Kaynaştırma öğrencisinin mevcut potansiyelini ortaya koyamaması, arkadaşları tarafından kabullenilmemesi, sınıfa sosyal uyum sağlayamaması, yalnız kalması, kendini ifade edecek ortam ve firsat bulamaması öğrencinin hem akademik hem de sosyal becerilerini sınırlandırmamakta ve normal gelişim gösteren akranlarıyla arasındaki farkın açılmasına neden olmaktadır (Sucuoğlu ve Kargın, 2006). Kaynaştırma öğrencisinin sınıf içinde kabulünü sağlama, bu konuda öğretmen yeterlilikleri, tutum değiştirme, öğretimsel düzenlemeler gibi alan yazın çalışmaları yapılsa da kaynaştırma öğrencileri sosyal ve akademik yönden hâlâ dezavantajlı, etiketlenmiş ve yalnız öğrencilerdir.

Kaynaştırma yoluyla eğitim 2006 tarihli ve 26184 sayılı Resmi Gazete'de; özel eğitime ihtiyacı olan bireylerin eğitimlerini, destek eğitim hizmetleri de sağlanarak yetersizliği olmayan akranları ile birlikte resmî ve özel okul öncesi, ilköğretim, ortaöğretim ve yaygın eğitim kurumlarında sürdürmeleri esasına dayanan özel eğitim uygulamaları olarak tanımlanmıştır. Kaynaştırma yoluyla eğitimin özel gereksinimli birey için birçok faydası vardır ve en az kısıtlanmış ortamda yapılan öğretimsel düzenlemelerde başarılı oldukları yapılan araştırmalarda görülmektedir (Güzel-Özmen, 2009). Kaynaştırma yoluyla eğitimin özel gereksinimli birey dışında ailelere, normal gelişim gösteren bireylere ve öğretmenlere de birçok katkısı vardır. En az kısıtlayıcı ortam özel gereksinimli bireyin toplumla bütünleşmesini kolaylaştıracak, akran öğretimi, gözleyerek öğrenme gibi durumlardan da faydalanmasını sağlayacaktır. Özel gereksinimli bireylerin toplumla bütünleşmesinin önündeki engellerden biri olan olumsuz tutumlarla başa çıkılmasında da kaynaştırma yoluyla eğitim iyi bir yoldur. Özel gereksinimli bireyin ötekileştirilmesi onun anlaşılamamasına, yalnız kalmasına neden 
olmaktadır. En az kısıtlayıcı ortamdaki özel gereksinimli bireyin akranlarıyla kuracağı etkileşim, bireylerin birbirini anlamasını sağlayacak, bu da bütünleşmeye katkıda bulunacaktır. Bu nedenle özel gereksinimli bireylerin eşitlikçi bir yaklaşım içerisinde akranlarıyla etkileşimde bulunması için alanlar artırılmalı ya da var olan alanlara ulaşmaları sağlanmalıdır. Tüm bireyler arasında etkileşim sağlayan disiplinlerden biri de yaratıcı dramadır (Genç, 2003; Adıgüzel, 2013). Yaratıcı drama ile ilgili birçok tanım yer almaktadır Adıgüzel (2013)'e göre; "Bir grubu oluşturan üyelerin yaşam deneyimlerinden yola çıkarak, bir amacın, düşüncenin, doğaçlama, rol oynama ve diğer tekniklerden yararlanılarak canlandırılmasıdır. Bu canlandırma süreçleri deneyimli lider/eğitmen tarafından yürütülürken şimdi ve burada ilkesine, kendiliğindenliğe, mış gibi yapmaya dayalıdır ve oyunun genel özelliklerinden yararlanır." San (2002) ise yaratıcı dramayı; "Doğaçlama, rol oynama gibi tiyatro ya da drama tekniklerinden yararlanılarak, bir grup çalışması içinde, bireylerin bir yaşantıyı, bir olayı, bir fikri, kimi zaman bir soyut kavramı ya da bir davranışı eski yaşamların tekrar gözden geçirilmesi yoluyla canlandırılması" şeklinde tanımlamıştır. Ayrıca Isenberg ve Jalongo (1993) yaratıcı dramayı, çocukların bedensel ve kinestetik kapasitelerini artırarak, grupla çalışma becerilerini ve birlikte öğrenme becerilerini geliştirdikleri bir süreç olarak tanımlamışlardır.

Yaratıcı drama, diğer alanlardaki öğrenmeleri geliştirmek ve motivasyonu artırmak için kullanılabilir. Yaratıcı dramaya katılım, dil ve iletişim yeteneklerini, problem çözme becerilerini ve yaratıcılığı geliştirebilmekle birlikte, olumlu benlik kavramını, sosyal farkındalığı, empatiyi artırabilmeye, değer ve tutumları aydınlatabilmeye ve tiyatro sanatını anlamaya potansiyel sağlayabilmektedir (Uşaklı, 2006). Yaratıcı drama etkinlikleri sayesinde çocuklar, kendilerini özgürce ifade edebilmekte, maskelerinden kurtulup özgüvenlerini ortaya çıkarabilmektedirler (Çalıskan, 2005). Benlik algısı düşük, özgüven bakımından yetersiz olan çocukların akranlarıyla sosyal ilişkiler kurmakta zorlanacakları, bir grup içerisinde söz almaktan kaçınarak yalnızlaşacakları düşünüldüğünde; bu tarz durumdan etkilenen çocukların sınıf içerisindeki başta akademik olmak üzere diğer etkinliklere de katılım sağlamada yetersiz kalabilecekleri görülmektedir.

Sınıf içi etkinliklere katılım; öğrencinin istenen davranışı kazanması için kendisine sağlanan işaretlerle belli bir düzeyde açık ya da örtük olarak etkileşmesi ve bu çabayı davranışı kazanıncaya kadar sürdürmesidir (Bloom 1976). Öğretim ortamında öğrencilerin ilgisini çekmenin ve bunu sürdürmenin sırrı öğrencinin sınıf içi etkinliklere katılımını sağlamaktır (Aksoy, 2000). Ancak öğrencinin etkinliklere katılımını etkileyen birçok unsur vardır. Bu etkenlerin başında öğretme öğrenme ortamı ve öğrencinin özellikleri gelir. Öğrencinin özel ve genel yetenekleri, öğrencinin yavaş ya da hılı öğrenme durumu, aç, uykulu ya da hasta olması, psikolojik olarak rahat olup olmaması etkinliklere katılımını etkiler. Bunun yanında öğrenme ve öğretme ortamında öğretmenin tutumu, dersi işleme biçimi, iletişim becerileri, öğretim yöntem ve teknikleri, sınıfin fiziksel özellikleri de sayılabilir. Katılımı etkileyen ortam ve öğrenci özellikleri göz önüne alındığında özel gereksinimli bir bireyin öğrenme açısından getirdiği dezavantajlar ve yetersizlikler -gerekli düzenlemeler yapılmadığında- öğrencinin başarısız olmasına neden olur. Kaynaştırma eğitimindeki aksaklıklarla beraber, kaynaştırma öğrencilerinin derslerdeki olumsuz yaşantıları da özgüven seviyelerinin düşük olmasına yol açar. Özgüven seviyesinin düşüklüğüyle birlikte, bireyin ve gelişimin bir bütün olduğu göz önüne alındığında, akademik alandaki başarısızlıkların sosyal alana da yansıyacağını görmek olağan bir durumdur. Öğrenme ortamlarında olumsuz yaşantı biriktiren çocukların öğrenmeye karşı isteksiz hale gelmesi ve motivasyon kaybı yeni öğrenmeler edinmesinin önüne geçmekte, bu da öğrenmeye karşı istek duyma, merak etme, yeni öğrenmeler talep etme, derse katılma, cevap verme, 
fikir ifade etme gibi alanlarda anlamlı farklılıklara neden olmaktadır. Yaratıcı dramanın felsefesinde yer alan ve uygulama sürecinin getirdiği eşitlik, sıkça onanıp başarılı hissetme, bütünün bir parçası olduğunun farkına varma, duygularla iç içe olma, hata yapma özgürlügünün olması, bireyi güvende hissettirmektedir. Yaratıcı drama etkinliklerinde oyunlardan faydalanılması süreci eğlenceli hale getirmektedir, bu durum çocuğun öğrenmeyi talep etmesini sağlar. Yaratıcı dramanın oyunsu bir süreç olduğu düşünülürse katılımcının bu süreçte kazanma ve kaybetmenin normal bir durum olduğunu etkinlik içerisinde gelişen empatik süreçle fark etmesi, içselleştirmesi beklenen bir durumdur. Özel gereksinimli bireylerin öğrenmeye karşı olan olumsuz tutumları düşünüldüğünde yaratıcı drama bir yöntem olarak da yukarda söz edilen nedenlerden dolayı güçlü bir araçtır. Ayrıca yapılandırmacı yaklaşım doğrultusunda yenilenen Hayat Bilgisi dersi öğretim programında kazandırılması beklenen eleştirel düşünme, yaratıcı düşünme, iletişim, problem çözme gibi beceriler ile özsaygı, özgüven, hoşgörü, saygı, sevgi, yeniliğe açıklık gibi kavramlar yaratıcı dramanın doğasında dinamik bir biçimde bulunmaktadır (MEB 2009).

\section{Araştırmanın Amacı}

Çalışmanın amacı, genel eğitim sınıfına devam eden kaynaştırma öğrencisinin sınıf içi etkinliklere katılım düzeyine yaratıcı dramanın etkisini araştırmaktır. Bu genel amaç doğrultusunda; deneğin gözlem formlarına dayalı olarak aşağıdaki sorulara yanıt aranmıştır:

1. Deneğin arkadaşlarıyla etkileşimde bulunma düzeyi nedir?,

2. Deneğin liderle/öğretmenle etkileşimde bulunma düzeyi nedir?

3. Deneğin etkinliklere karşı tutumu ile genel performansı nasıldır?

\section{Yöntem}

\section{Araștırmanın Modeli}

Tek denekli araştırma desenleri, nicel deneysel modeller içerisinde yer alan, benzer özellikte denek gruplarına ulaşmanın güç olduğu durumlarda kullanılan desenlerdir. Bu model araştırmalarda veriler grafiksel ve istatistiksel olarak analiz edilir (Kırcaali-İftar 2012). Araştırma tek denekli araştırma modellerinden ABA temel modelinde desenlenmiştir, bu model temel tek denekli tasarımdır. ABA modelinin tek bir uygulamanın etkililiğini incelemeye çalıştığı söylenebilir (Tekinİftar, Kırcaali-iftar 2012). Araştırmanın bağımsız değişkeni yaratıcı drama iken bağımlı değişkeni sınıf içi etkinlik katılım düzeyi olarak belirlenmiştir.

\section{Çalışma Grubu}

Araştırmanın çalışma grubu, Konya'nın Meram ilçesinde bulunan bir ilkokulun 2. sınıfina devam eden, normal gelişim gösteren, sosyo-ekonomik düzeyi düşük ve orta 13 erkek, 6 kız ve öğrenme güçlügüne sahip bir kız çocuktan oluşmuştur. Çalışma grubu amaçlı örneklem yoluyla belirlenmiştir. Amaçlı örneklem araştırmacının belli özelliklere sahip bir örneklemde derinlemesine bilgi sağlamak için tercih ettiği bir yöntemdir (Büyüköztürk vd., 2017). Örneklem seçilirken şu özelliklere sahip olması aranmıştır: Okulun sosyoekonomik olarak düşük bir bölgede yer alması, drama çalışmalarına uygun halı zeminli geniş bir salonunun bulunması, çalışma yapılacak sınıf mevcudunun 24 öğrenciden az olması, drama etkinliği için gönüllü olmaları, sınıfta kaynaştırma 
tanılı öğrencinin bulunması, kaynaştırma öğrencisinin öğrenme güçlügü tanısı almış olması, öğrencinin derslere katılım göstermemesi ve hareketli oyunlara katılmasını engelleyecek herhangi fiziksel ya da duyusal yetersizliğinin olmaması aranan özelliklerdir. Denek 8 yaşında, düşük sosyo ekonomik düzeye sahip, öğrenme güçlüğü tanısı almış, sınıfın yaş olarak en küçük öğrencisidir. Öğretmen ifadelerine göre; 20 kişilik genel eğitim sınıfında en arkaya oturan, derslerde söz hakk1 almayan, kendini ifade etmeyen ve bu firsatı bulamayan, akranları tarafından dışlanmış, serbest zaman etkinlikleri, oyun, fiziksel aktiviteler, resim vb. derslerde de dişarıda kalan bir öğrencidir.

Çalışma, on dört hafta boyunca haftada bir kez gerçekleştirilen 45 dakikalık yaratıcı drama oturumundan oluşmaktadır. Yapılacak etkinlikler ve planlar, yaratıcı drama alanında uzmandan görüş alınarak hazırlanmış, oturumlar yaratıcı drama alanında uzman bir lider/eğitmen tarafından yürütülmüştür. Yaratıcı drama çalışmaları halı zemini olan okulun bodrum katında yer alan bir sınıfta gerçekleştirilmiş, etkinliklerin gerektirdiği müzik ve materyaller sağlanmıştır.

\section{Veri Toplama Araçları}

Ölçme aracı, araştırmacı tarafından geliştirilen bir gözlem formudur. Form hazırlanırken iki farklı uzman görüşü alınmıştır. Etkinlik katılım kontrol listesi üç farklı alanda öğrencinin düzeyini belirlemeye yöneliktir. $\mathrm{Bu}$ alt alanlarda arkadaşlarıyla etkileşimde bulunma, lider/öğretmenle etkileşimde bulunma ve etkinliğe karşı olumlu tutum ve performans düzeyi yer almaktadır. Her maddenin en az 0 , en çok 5 olmak üzere 6 puan değeri üzerinden puanlanması istenmiştir. Alınan puanlar üç alt başlığa genel performans da eklenerek grafiklere dönüştürülmüştür.

Verilerin güvenirliğini desteklemek adına 3 gözlemciden de çocuğun mevcut performansı hakkındaki görüşleri alınmış. Gözlemcilerden her hafta için gözlemlerini yazmalarını ve deneğin süreç boyunca betimlenmesi istenmiştir. Toplanan gözlemler betimsel analizle çözümlenmiştir.

\section{Verilerin Toplanması}

Çalışmanın konusu olan denek üç farklı gözlemci tarafından gözlenmiştir. Birinci gözlemci, uygulamaları yürüten yaratıcı drama eğitmeni olup aynı zamanda özel eğitim lisans programına devam etmektedir. Ayrıca yaratıcı drama alanında dört yıllık bir deneyime sahiptir. İkinci gözlemci çalışmaların yürütüldüğü ve deneğin bulunduğu sınıfın öğretmenidir. Öğretmen okulu mezunu olup, 20 yıllık mesleki deneyime sahiptir. Ancak özel eğitim ve yaratıcı drama alanında herhangi bir eğitime katılmamıştır. Üçüncü gözlemci ise deneğin destek eğitim öğretmenidir. Sınıf öğretmenliği alanında lisans mezunu olup özel eğitim uzman öğretici kursuna katılarak özel eğitim alanına devam etmektedir. Aynı zamanda yaratıcı drama eğitimi almıştır.

Çalışma, düşük ve orta sosyoekonomik düzeye sahip bir ilkokulda, okulun bodrum katında bulunan halı zemine sahip sınıfta deneğin tüm sınıfıyla beraber yürütülmüştür. Çalışma, 2015-2016 eğitim öğretim yılının bahar döneminde, her cuma günü 45 dakika sürecek şekilde, haftada bir oturum olmak üzere uygulanmıştır. Uygulamada 3 oturum deneğin uygulama öncesi performansının alınması, 8 oturum yaratıcı drama uygulamasının yapılması, 3 hafta genelleme performansının (deneğin farklı ortamlarda ve etkinliklerdeki düzeyini) alınması olmak üzere 14 hafta olarak planlanmış ve gerçekleştirilmiştir.

Uygulamaya konulan yaratıcı drama atölyeleri bir uzman tarafından kontrol edilmiştir. Uygulama öncesinde araştırma ve araştırmanın konusu gözlemcilerle paylaşılmış, üç hafta boyunca 
cuma günleri sınıf öğretmeninin hazırladığ1 ve uyguladığı etkinliklerde deneğin performansı kontrol listesi aracılığıyla puanlanmış, başlangıç düzeyi üç gözlemci tarafından betimlenmiştir. Uygulama öncesi performansın alınmasının ardından yaratıcı drama liderinin uygulamalarına geçilmiş, uygulama sırasında iki farklı gözlemci herhangi bir müdahalede bulunmaksızın gerçekleşen etkinlikleri izlemiş, diğer gözlemci etkinliği yürütmüş, ardından tüm gözlemciler kontrol listelerini doldurmuş ve görüşlerini yazılı olarak vermişlerdir. Yaratıcı drama uygulamalarının 6. oturumunda denek tüm gözlemciler tarafından en yüksek puanı almış, 7. ve 8. oturumda da bu performansı sürdürmeyi başarmıştır. Yaratıcı drama oturumları bittikten sonra deneğin mevcut performans genelleme düzeyinin belirlenmesi için haftada bir kez olmak üzere üç hafta daha sınıf öğretmeninin deneğin kendi sınıfında ve bahçede yaptırdığı etkinlikler izlenerek alınmıştır.

\section{Bulgular}

Kaynaştırma öğrencilerinin sınıf içi etkinliklere katılım düzeyini araştıran bu çalışmada; kaynaştırma öğrencisinin arkadaşlarıyla etkileşimde bulunma düzeyi, liderle/öğretmenle etkileşimde bulunma düzeyi ve etkinliklere karşı tutum düzeyini ortaya koymak amaçlanmıştır.

Araştırmanın birinci denencesinde yaratıcı dramaya etkinliklerinin kaynaştırma öğrencisinin sınıf içinde arkadaşları ile etkileşimini olumlu yönde artıracağı kabul edilmiştir. Deneğin arkadaşlarıyla etkileşimde bulunmasına ilişkin gözlem formlarına dayalı olarak elde edilen veriler Grafik 1'de gösterilmiştir.

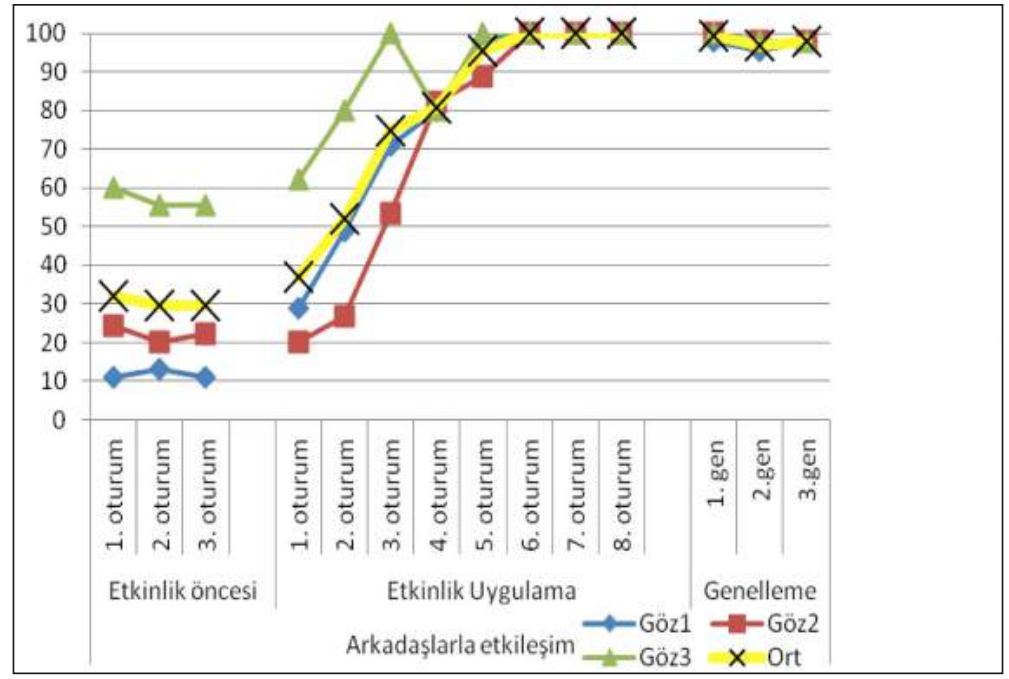

Grafik 1. Arkadaşlarıyla Etkileşimde Bulunmasına İlişkin Elde Edilen Veriler

Arkadaşlarıyla etkileşimde bulunmaya ilişkin elde edilen verilerin yer aldığ grafik 1 incelendiğinde; öğretmen ifadelerine ve derecelendirme formuna göre bu alan deneğin en düşük performans gösterdiği alandır. Etkinlik öncesi ortalama puan açısından deneğin arkadaşlarıyla etkileşim düzeyinin 30 puan dolaylarında olduğu ve verilerin kararlılığ ile verilen puanların paralel olduğu ancak yaratıcı drama oturumlarının devam etmesiyle deneğin arkadaşlarıyla etkileşiminin arttığ1 görülmüştür. Genelleme oturumlarında ise etkileşim düzeyinin korunduğu söylenebilir. 
Gözlemcilerin gözlem sonuçlarından elde edilen verilerde uygulama öncesinde arkadaşlarıyla etkileşim kurmada deneğin dışlandığı, yalnız olduğu, çekindiği, mutsuzluğu, soğuk ve yabancı oluşu ön plana çıkmıştır.

Liderle etkileşimde bulunma alanında; deneğin etkinliği sürdüren yetişkinden söz hakk1 istemesi, görevler dağıtılırken talepte bulunmas1, verilen görevleri yapması, etkinlik içindeki sorumluluklarını yerine getirirken dönütte bulunması, sorulan sorulara cevap vermesi gibi alanlarda düzeyin yaratıcı drama ile arttırılacağı öngörülmüştür.

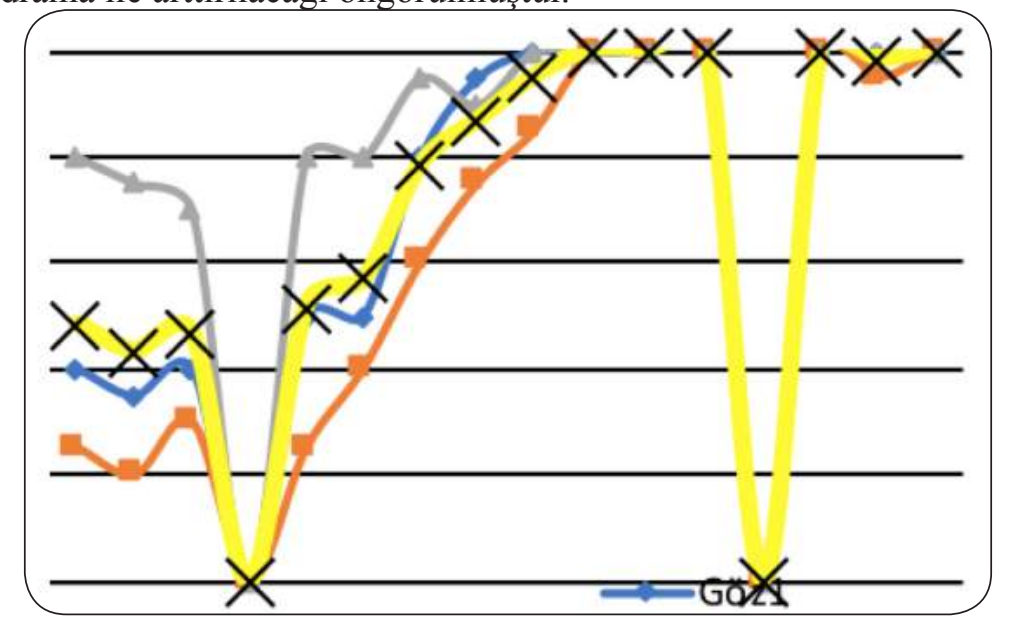

Grafik 2. Liderle Etkileşimde Bulunmasına İlişkin Elde Edilen Veriler

Grafik 2 incelendiğinde; deneğin liderle etkileşimde bulunma düzeyinin başlangıçta 50 puan dolaylarında olduğu ve verilerin kararlılı̆̆1, verilen puanların paralel olduğu görülmektedir. Yaratıcı drama oturumlarının devam etmesiyle bu alanda da öğrencinin performansının gittikçe arttığı ve genelleme oturumlarında bunun devam ettiği söylenebilir.

Bu alanla ilgili gözlemcilerin gözlem sonuçlarından elde edilen verilerde uygulama öncesinde deneğin söz hakk1 istemediği, verilen yönergelere uymadığ1, sorulan sorulara cevap vermekten kaçındığı, utandığı yer almaktadır.

Çalışmadaki bir diğer alan olan etkinliklere karşı olumlu tutum gösterme ve etkinlik performansı alanında; denekten etkinliğe isteyerek katılması, etkinliği başından sonuna kadar sürdürmesi, etkinlik sırasında mutlu görünmesi, kurallara uyması, ihtiyaç duyduğunda yardım talebinde bulunması, gerektiğinde liderlik etmesi, görev üstlenmesi gibi ölçütlerde yaratıcı dramanın etkiliği incelenmiştir. Aşağıdaki grafikte deneğin etkinliklere karşı tutumu ve performansı gösterilmektedir. 


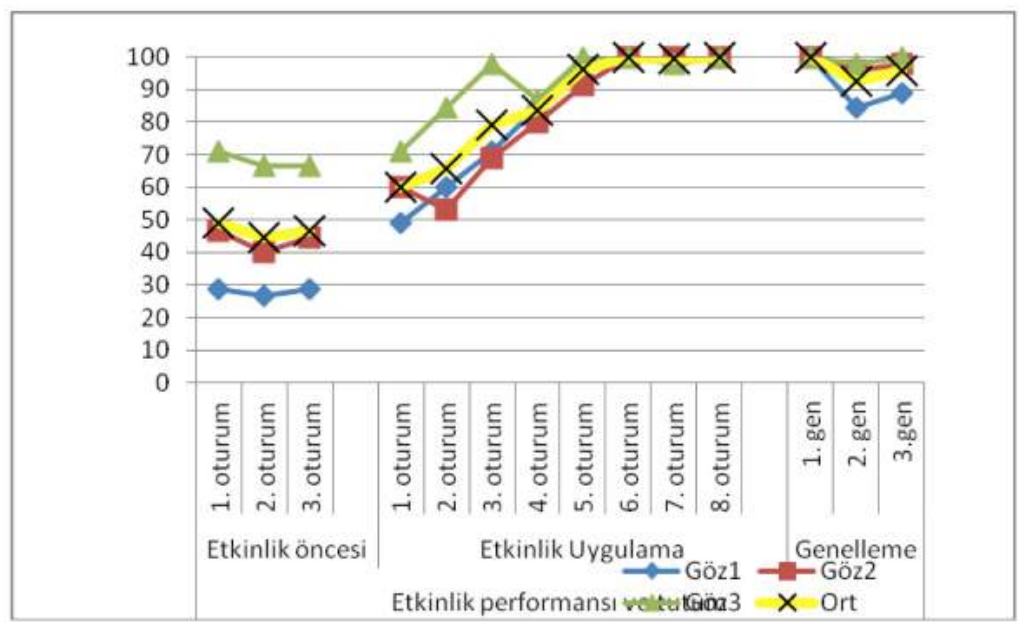

Grafik 3. Deneğin Etkinlik Performansı ve Tutumuna İlişkin Elde Edilen Veriler

Grafik 3 incelendiğinde; deneğin etkinliklere karşı tutumunun ve performansının kontrol listesine göre başlangıçta 45 puan dolaylarında olduğu, verilerin kararlı ve paralel olduğu, yaratıcı drama oturumlarıyla beraber deneğin bu alanda da ilerleme kaydettiğini ve bunu genelleme oturumlarında da sürdürdüğü görülmektedir.

Gözlemcilerden alınan nitel verilerde ise uygulama öncesinde deneğin rekabet etmediği, etkinlikler esnasında mutsuz ve isteksiz olduğu, etkinliklerin dışında kaldığı, etkinlikleri sürdüremediği, kendini değerlendirmediği, yönergelere uymadığı, verilen görevi yerine getirmede özensiz olduğu ifade edilmiştir.

Şimdiye kadar sözü edilen tüm alanların tamamının ortak olarak değerlendirileceği aşağıdaki grafikte deneğin kontrol listesine göre aldığı toplam puanlar gösterilmektedir.

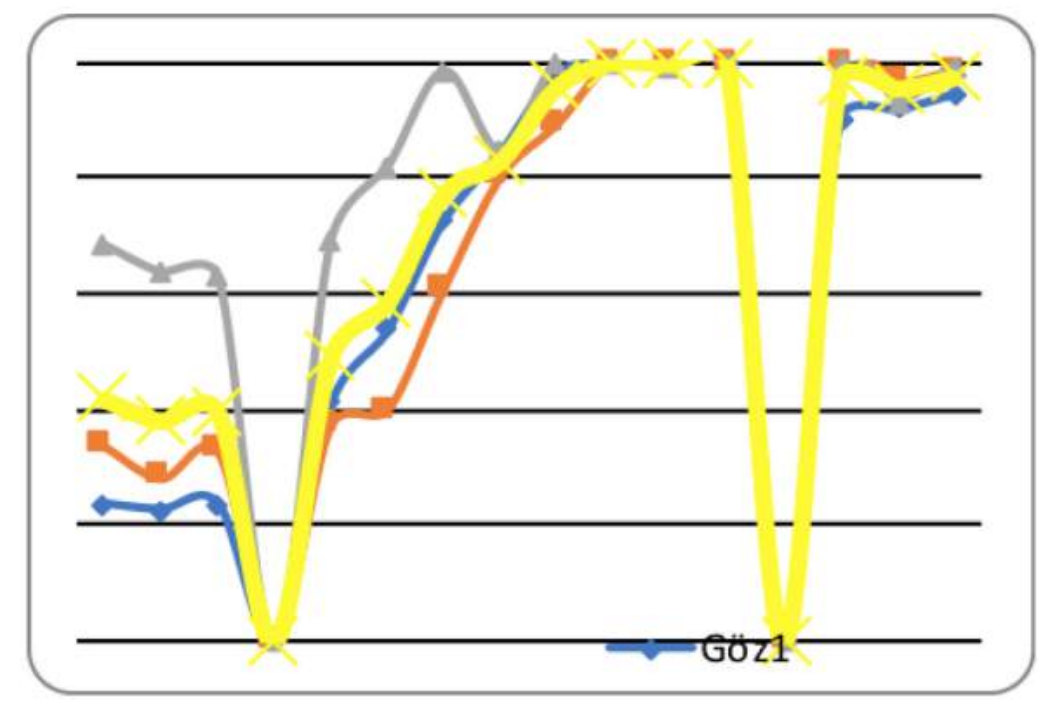

Grafik 4. Deneğin Genel Performansına İlişkin Veriler

Grafik 4'te deneğin tüm alt başl1kların dahil olduğu genel performansı görülmektedir. Deneğin genel performansının 40 puan dolaylarında olduğu, uygulamalarla beraber aldığı puanların giderek 
yükseldiği ve genelleme oturumlarında da bu performans1 sürdürdüğü, gözlemcilerin puanlarında paralellik olduğu görülmektedir.

Uygulama öncesi performansının nitel olarak betimlemesinde gözlemciler; öğrencinin etkinliklerde geride durduğundan, rekabet etmediğinden, çekindiğinden, arkadaşları tarafindan dışlandığından, oyunun ve etkinlik dışında kaldığından, mutsuz ve isteksiz oluşundan, fiziksel ve zihinsel olarak zayıf olduğundan, okula ve arkadaşlarına karşı soğuk ve yabancı olduğundan, sorulan sorulara utanarak cevap vermesinden ve bunların akademik alanı da etkilediğinden söz etmişlerdir.

Yaratıcı drama oturumlarının devam ettiği ve son oturum dahilinde alınan nitel verilerde; deneğin arkadaşlarıyla etkileşimde bulunduğu, oyun ve etkinlikleri sürdürebildiği, öğretmenlerinden yardım beklemediği, etkinliklerden zevk aldığı, mutlu göründüğü, grup oluşturabildiği, gruplara dahil olabildiği, sınıfıyla uyum içinde olduğu, etkinliklerinden sonra öz değerlendirmesini yapabildiği, kendini iyi ifade ettiği, duygu ve düşüncelerini paylaştığı, sorulan sorulara utanmadan cevap verdiği, okumada istekli olduğu ve akademik alanda da istekli olmaya başladığı, artık ön sırada oturduğu dile getirilmiştir. Denek için "Solmak üzere olan bir çiçeğin yeniden canlandı̆̆̆” ifadesi kullanılmıştır. Yaratıcı drama çalışmalarının denek için çok faydalı oluğunu, akademik fayda sağlayabileceğini, programlarda yaratıcı dramaya yer verilmesi gerektiğini ve kaynaştırma öğrencileri ile ilgili etkinlikler yapılması gerektiğini söylemişlerdir. Deneğin bu davranışı sürdürdüğü genelleme oturumlarında görülmektedir.

\section{Tartışma, Sonuç ve Öneriler}

Araştırma yaratıcı drama dersi alan kaynaştırma öğrencisinin sınıf içi etkinliklere katılım düzeyine etkisini belirlemek amacıyla yapılmıştır. Bu kapsamda; nicel ve nitel veriler toplanmış, elde edilen veriler analiz edilmiştir. Yaratıcı drama çalışmalarından önce deneğin etkinliklere katılmak istemeyen, söz hakk1 almayan, başladığı etkinliği yarıda bırakan, öğretmenle ve arkadaşlarıyla iletişime geçmekten kaçınan bir performans sergilediği ancak yaratıcı drama uygulamaları sonrasında arkadaşlarıyla etkileşimde bulunduğu, arkadaş grubunda kendine yer bulabildiği, etkinliklere isteyerek katıldığı, etkinlik esnasında mutlu olduğu ve bunu sürdüğü, söz aldığı, kendini ifade ettiği görülmüştür. Benzer şekilde Yaşaran (2009) normal gelişim gösteren öğrencilerin özel gereksinimli bireylerin sosyal kabullerini sağlamada kaynaştırmaya hazırlık etkinliklerinin etkiliğini incelemiş ve bu etkinliklerin olumlu gelişmeler yarattığı sonucuna ulaşmıştır. Aynı şekilde Öztürk-Özgönel (2012) otizm tanılı kaynaştırma öğrencilerinin bulunduğu sınıflarda akran ilişkilerinin geliştirilmesine yönelik eğitim programının etkililiğini incelemiş ve etkili olduğunu saptamıştır.

Kaynaştırma öğrencisi, liderle/öğretmenle etkileşimde bulunma, iletişim kurma, sürdürme, söz hakkı isteme, yardım isteme konusunda olumlu gelişmeler göstermiştir. Guli vd. (2013)'nin yaptığ1 pilot çalışmada otizm spektrum bozukluğu, dikkat eksikliği ve hiperaktivite bozukluğu, öğrenme güçlüğü olan bireylerle yaptığı yaratıcı drama çalışmalarının sosyal becerileri geliştirdiğini ortaya koymuştur. Benzer şekilde Boran (2010), risk gruplarıyla sosyal alanda yaratıcı drama çalışmalarının etkilerini zihin engelli ve öğrenme güçlüğü olan bireyler üzerinden incelemiş ve temel sosyal beceriler, saldırgan davranışlarla başa çıkma becerileri, ileri konuşma becerileri, bilişsel beceriler ve ilişkiyi başlatma becerilerini geliştirici etkisi olduğunu ortaya koymuştur. Önalan-Akfirat (2004) yaratıcı dramanın işitme engelli bireylerin sosyal becerilerinin geliştirilmesinde etkili olduğunu, Alp (2008) sosyal uyum bozukluğu gösteren çocukların uyumsal davranışlarına kaynaştırılmış ders 
dışı hareket ve oyun etkinliklerinin etkisini incelemiş ve sosyal uyum problemi gösteren çocuklarda iyileşme saptamıştır. Başka bir çalışmada Çetin (2005) zihin engelli öğrenciler için hazırlanan sosyal beceri öğretim programının etkililiğini incelemiş ve etkili olduğunu saptamıştır.

Kaynaştırma öğrencisi; etkinliklere olumlu tutum geliştirme, etkinliğe katılma, etkinlik sırasında istekli ve mutlu olma, kendini ifade etme, değerlendirme, etkinlikte tam performans gösterme konusunda olumlu gelişmeler göstermiştir. Araştırma sonucunda elde edilen verilerde yer alan bu olumlu gelişmelerin öğrencinin akademik alanda başarısını artırması alan yazında birçok çalışmayla desteklenmiştir. Bu çalışmada ise yaratıcı drama dersinin kaynaştırma öğrencisinin sınıf içi etkinliklere katılımını artırdığı gösterilmiştir.

Araştırma sonucunda elde edilen veriler doğrultusunda aşağıdaki önerilerde bulunulabilir:

- Kaynaştırma öğrencilerinin dezavantajlı olduğu bilinmektedir bu dezavantajlar öğrencilerin sınıfıyla bütünleşmelerini olumsuz yönde etkileyebilir. Bu etkilenme olmaksızın kaynaştırma öğrencilerinin sınıflarında, sınıfın bütünlügünü sağlayacak yaratıcı drama etkinlikleri yapılabilir.

- Başka bir disiplin ya da yöntemle yaratıcı dramanın etkililiği karşılaştırılabilir.

- Kaynaştırma öğrencilerinin sosyal kabulü ve sınıf içi etkinliklere katılımının artırmasını sağlayabilecek farklı disiplin ya da yöntemlerin etkililiği araştırılabilir. 


\section{Kaynakça}

Adıgüzel, Ö. (2013). Eğitimde yaratıcı drama. Ankara: Pegem Akademi Yayıncılık.

Aksoy, S. (2000). Öğrencilerin derse katılımını sağlama yolları. Bilim ve Aklın Aydınlığında Eğitim Dergisi, 15(3), 28-40.

Alp, H. (2008) Sosyal uyum bozukluğu gösteren çocukların uyumsal davranışlarına kaynaştırılmış ders dışı hareket ve oyun etkinliklerinin etkisi. (Yayınlanmamış Yüksek Lisans Tezi). Celal Bayar Üniversitesi. Sağlık Bilimleri Enstitüsü. Manisa.

Batu, S. ve Kırcaali-İftar, G. (2006). Kaynaştırma, Ankara: Kök Yayıncılık.

Bloom, B. S. (1976). Human characteristics and school learning. New York: McGrawHill.

Boran, E. (2010). Risk gruplarıyla sosyal alanda yaratıcı drama çalı̧̧malarının etkisi. (Yüksek Lisans Tezi). İstanbul Üniversitesi. Sosyal Bilimler Enstitüsü. İstanbul.

Büyüköztürk Ş., Kılıı̧-Çakmak E., Akgün E.Ö., Karadeniz Ş., Demirel F. (2017). Bilimsel araştırma yöntemleri. Ankara: Pegem Akademi Yayıncıllk.

Çalışkan, A. (2005) Ruhsal ve bedensel rahatlı̆̆n yeni adresi 'Yaratıcı drama kulüpleri'. Yeni Asır, Pazar Sarmaşık, (1).

Eldeniz-Çetin, M. (2005) Zihin engelli öğrenciler için drama yöntemine göre hazırlanan sosyal beceri öğretim programının etkililiğinin incelenmesi. (Yayınlanmamış Yüksek Lisans Tezi). Abant İzzet Baysal Üniversitesi. Sosyal Bilimler Enstitüsü. Bolu.

Genç, N. H. (2003). Eğitimde yaratıcı dramanın alımlanması. Hacettepe Üniversitesi Eğitim Fakültesi Dergisi. (24) 196-205.

Guli, L. A., Semrud-Clikeman, M., Lerner, M. D., \& Britton, N. (2013). Social Competence Intervention Program (SCIP): A pilot study of a creative drama program for youth with social difficulties. The Arts in Psychotherapy, 40(1), 37-44.

Güzel-Özmen, R. (2009). Kaynaştırma ortamlarında öğretimsel düzenlemeler. A. Ataman(Ed.), Özel gereksinimli çocuklar ve özel eğitime giriş (s59-86). Ankara. Gündüz Eğitim ve Yayıncılık.

Isenberg, J.P. and Jalongo, M.R. (1993). Creative expression and play in the early childhood curriculum. Simon \& Schuster Books For Young Readers.

Kırcali-İftar G, (2012). Tek denekli araştırmaların tarihçesi. E. Tekin-İftar (Ed.), Eğitimde Tek denekli araştırma yöntemleri s(1-10). Ankara: Türk Psikologlar Derneği Yayınları.

MEB (1973) Milli Eğitim Temel Kanunu, 14574 sayılı Resmi Gazete.

MEB (2006) 26184 say1l Resmi Gazete.

MEB (2006). Özel eğitim hizmetleri yönetmeliği.

Önalan-Akfırat F. (2004). Yaratıı dramanın işitme engellilerin sosyal gelişimine etkisi. Ankara Üniversitesi Eğitim Bilimleri Fakültesi Özel Eğitim Dergisi 5(1), 9-22.

Özkan-Yaşaran, Ö. (2009). Normal gelişim gösteren öğrencilerin özel gereksinimli bireylerin sosyal kabullenirini sağlamada kaynaştırmaya hazırlıklarının etkisi. (Yayınlanmamış Yüksek Lisans Tezi). Anadolu Üniversitesi. Eğitim Bilimleri Enstitüsü. Eskişehir.

Öztürk-Özgönel, S. (2012). Otizm tanılı kaynaştırma öğrencilerinin bulunduğu sınıflarda akran ilişskilerinin geliştirilmesine yönelik bir eğitim programının etkililiğinin incelenmesi. (Yayınlanmamış Doktora Tezi). Dokuz Eylül Üniversitesi. Eğitim Bilimleri Enstitüsü. İzmir.

San, İ. (2002). Eğitimde yaratıcı drama H.Ö. Adıgüzel. (Ed.), Yaratıcı drama Ankara: Naturel yayıncılık.

Sucuoğlu, B. ve Kargın, T. (2006). İlköğretimde kaynaştırma uygulamaları, İstanbul: Morpa Yayınları.

Tekin-İftar, E. ve Kırcaali-İftar G. (2012). Yanlıssız öğretim yöntemleri, Ankara: Vize yayıncılık.

Uşakl1, H. (2006) Drama temelli grup rehberliğinin ilköğretim V. sınıf öğrencilerinin arkadaşlı ilişsileri, atılganlık düzeyi ve benlik saygısına etkisi. (Yayınlanmamış Doktora Tezi). Dokuz Eylül Üniversitesi, Eğitim Bilimleri Enstitüsü, İzmir. 


\section{EK I: Örnek Oturum Planı}

Tarih: 08. 04. 2016

Konu: Etkileşim

Mekan: Yunus Emre İlkokulu Çok Amaçlı Salonu

Katılımcılar: 2A sınıfı öğrencileri 13 erkek $7 \mathrm{~K} 1 \mathrm{Z}$

Süre: 45 dakika

Araç ve gereç: Davul, taşıt resimleri, a4 kağıdı, kalem.

Yöntem/Teknik: Yaratıcı Drama (rol oynama, doğaçlama)

\section{Kazanım:}

1. Arkadaşlarıyla etkileşimde bulunur.

2. İletişim kurar.

3. Arkadaşlarıyla takım olarak hareket eder.

\section{SÜREÇ}

\section{Isınma}

Eğitmen çocuklarla çemberde buluşur ve herbirine nasıl hissettiğini sorar.

1. Etkinlik: Eğitmen davulu çocuklara gösterir. Eğitmen adını davula vurarak, tartımlayarak, ismini söyler. Davul sırayla çemberde gezer ve her çocuk adını tartımlar. İlk tur bitince ikinci turda çocuklar adlarının tartımını vururlar, arkadaşları vuran kişinin ismini söyler.

2. Etkinlik: Çocuklar ayağa kalkarlar. Eğitmen bir otomobil resmi gösterir. 'Şimdi hepiniz arabasınız. Davul yavaş ya da az sesli çalarsa yavaş, hızlı ve yüksek sesli çalarsa hızlı hareket edeceksiniz' der. Çocuklar davulun ritmine göre hareket ederler.

3. Etkinlik: Eğitmen çocuklara taşıt kartlarının olduğu torbayı uzatır. Her çocuk bir taşıt seçer. Eğitmen davula vurduğunda her çocuk elindeki taşıtın sesini çıkararak ya kendiyle aynı olan taşıtı bulur.

Eğitmen yeniden çocuklara taşıt kartlarının olduğu torbayı uzatır. Her çocuk bir taşıt seçer. Eğitmen davula vurduğunda her çocuk bu kez elindeki taşıtın hareketini yaparak kendiyle aynı olan taşıtı bulur. Sürecin nasıl geçtiği, eş bulmanın kolay olup olmadığı konuşulur.

\section{Canlandırma}

1. Etkinlik: Çocuklar iki gruba ayrılırlar. Eğitmen bir gruba gemi diğer gruba tren resmi gösterir. Gruplardan biri gemi diğeri tren olarak hareket edecektir. Gemi ve tren kopmamalı çok uyumlu hareket etmelidir.

\section{Değerlendirme}

1. Etkinlik: Eğitmen her çocuğa bir A4 kağıdı verir. Her çocuk origami olarak bir gemi yapar ve üzerine nasıl hissettiğini yazar. 



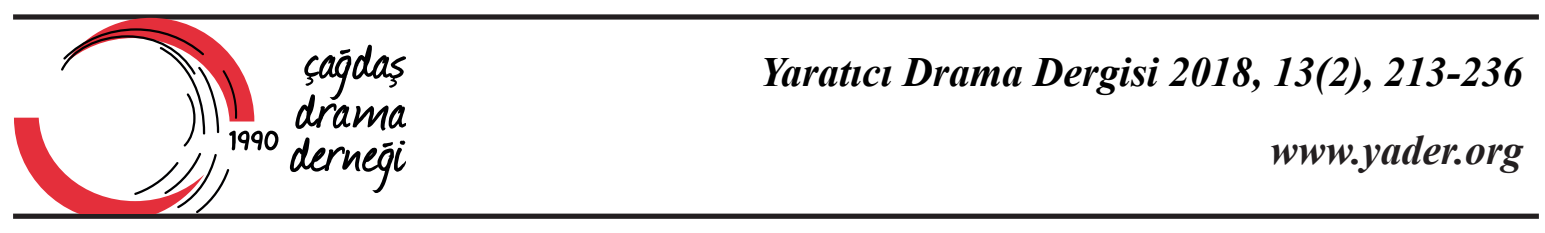

\section{İnsan İlişkileri ve İletişim Dersinde Yaratıcı Drama Uygulamalarının Etkisine İlişkin Öğrenci Görüşleri}

Mustafa Yeler ${ }^{1}$

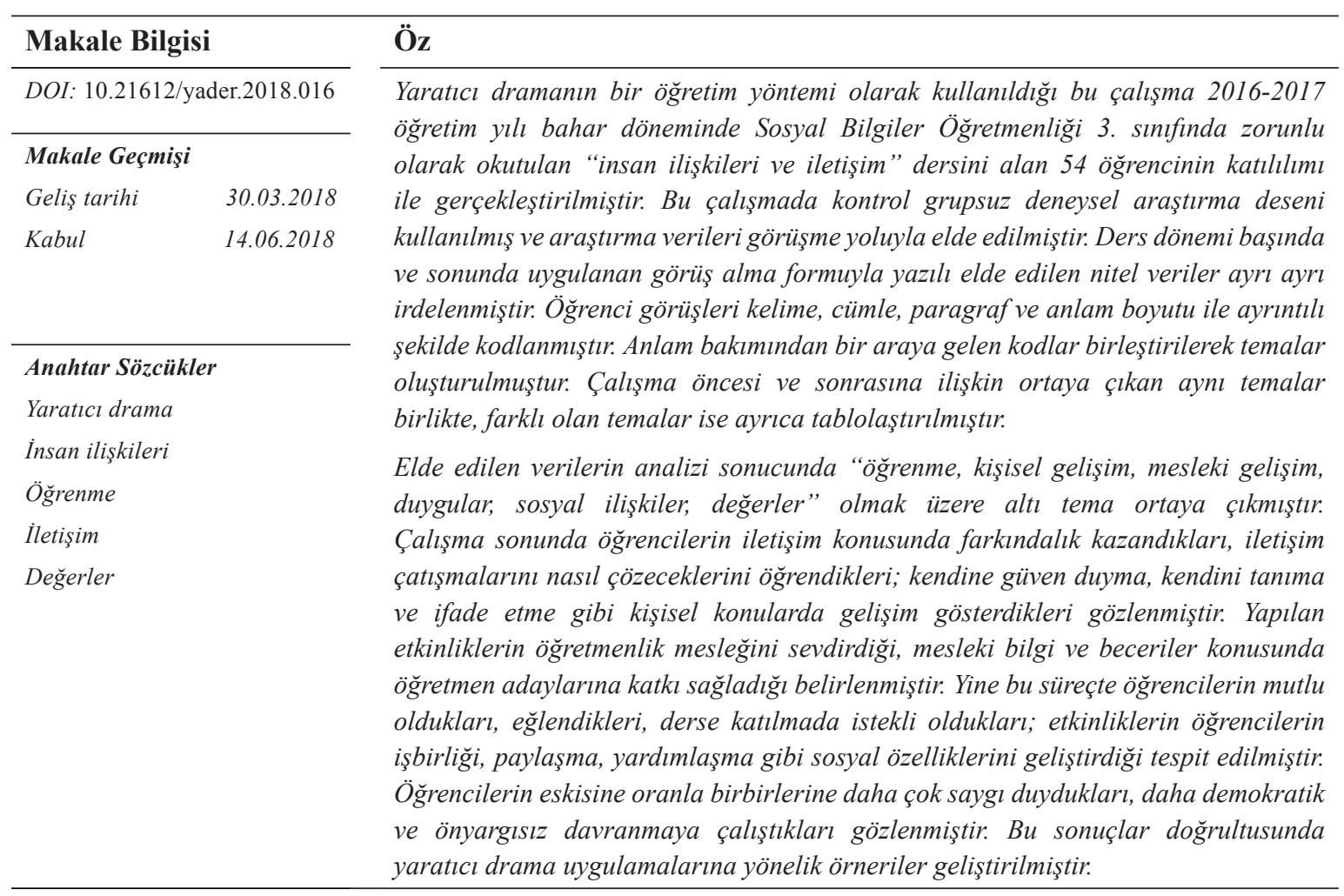

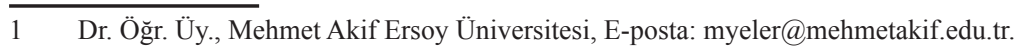




\section{Students' Views on the Effects of Creative Drama in Human Relationships and Communication Course}

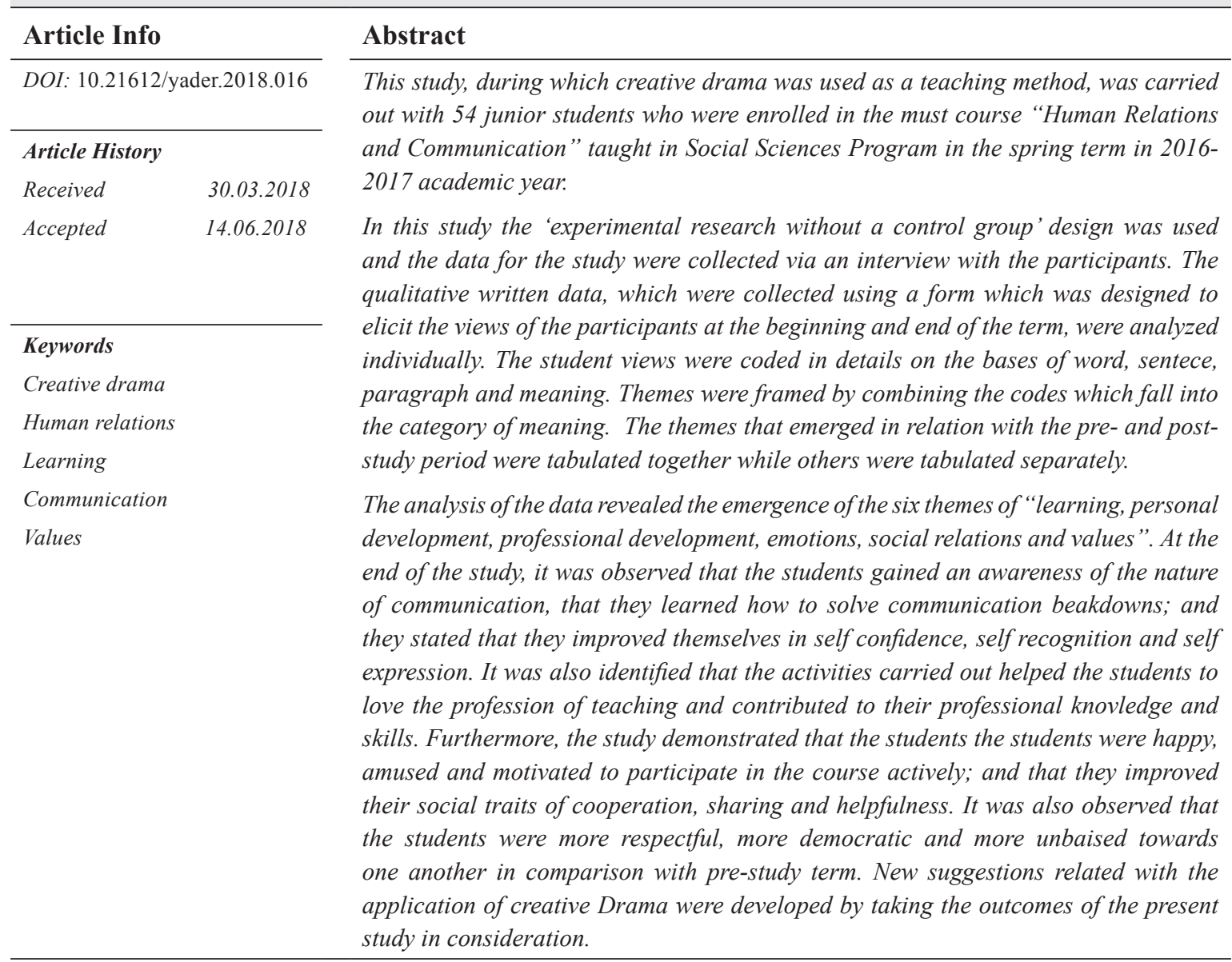




\section{Giriş}

İnsan, sosyal bir varlık olarak doğumundan ölümüne kadar olan süreyi toplum içinde yaşayarak geçirir. Bu sürecin verimliliği ve niteliği, kişinin toplum içindeki diğer insanlarla kurduğu iletişim ve etkileşime bağlıdır. Bu açıdan bakıldığında iletişim insan hayatında önemli bir yere sahiptir, bu doğrultuda iletişim "yaşamla iç içe” olarak nitelendirilebilir (Akoğuz, 2002) .

Türk Dil Kurumu (2009) sözlügüne göre, "duygu, düşünce ya da bilgilerin usa gelebilecek her türlü yolla başkalarına aktarılması” olarak tanımlanan iletişimin temel işlevini Yalın (2000) "anlamları ortak kılmanın yanı sıra duygu, düşünce, bilgi ve becerileri paylaşarak davranış değişikliği meydana getirmek" olarak vurgulamaktadır.

Öğretme-öğrenme sürecindeki yaşantılar açısından bakıldığında ise iletişim becerileri, öğretmenin mesleki ve kişisel özellikleri açısından da önemli bir yere sahiptir. Çünkü öğrenme süreci en genel anlamda bir iletişim sürecidir. Sınıf-içi iletişimin niteliği, öğrencilerin kişilik gelişimleri ve başarılarını etkileyen önemli bir unsurdur (Ergin ve Birol, 2000). Öğretme ve öğrenme süreçlerinde gerçekleştirilen tüm etkinlikler birer iletişim etkinliği olarak ele alındığında bu süreçlerin etkili olabilmesi için iletişim süreçlerinin de çok iyi planlanması ve uygulanması gerekmektir. Bu bağlamda söz konusu etkinlikler iletişimi artıracak işbirliğine dayalı öğrenme, drama, oyun vb. uygulamalarla yürütülebilir. Öğretme-öğrenme sürecinde iletişimi ve etkileşimi artıran en etkili öğretim yöntemlerden biri olarak yaratıcı drama ortaya çıkmaktadır. Çünkü Selimhocaoğlu (2004)'nun da belirttiği gibi yaratıcı drama da iletişim sanatlarından biri olarak düşünüldüğünde iletişim, dramanın hem amaçlarına ulaşmada bir amaç hem de tüm süreçlerinde yer alan bir kavramdır ve yaratıcı drama sürecine katılanlar için oldukça önemlidir. Başka bir ifade ile yaratıcı drama çalışmaları iletişim kurallarına da dayanır. Aynı zamanda bireylere iletişim becerilerinin kazandırılmasının gerekli ve önemlidir (Adıgüzel, 2013). Tüm bunlar düşünüldügünde yaratcı drama; “... bir grup çalışması içinde, bireylerin bir yaşantıyı, bir olayı, bir fikri, kimi zaman bir soyut kavramı ya da davranışı, eski bilişsel örüntülerin yeniden düzenlenmesi yoluyla gözlem, deneyim, duygu ve yaşantıların gözden geçirildiği süreçlerde anlamlandırması, canlandırması” olarak tanımlanmaktadır (San, 2006).

Bir başka deyişle yaratıcı drama eğitim sürecinde oyunlarla geliştirilen bir etkinlik olup bu özelliği ile eğitimin yaşamsal parçasıdır (Üstündağ, 1994). Drama etkinlikleri; bireylerin birbirleriyle etkileşim kurmalarını sağlayarak, bireyin grupla iletişimi, yaşantısını sürdürme, gruba ait olma ya da bir grubun üyesi olmanın getirdiği sorumluluk, iletişim ve problem çözme becerilerinin de gelişmesine katkıda bulunduğu gibi aynı zamanda bireylerin kendilerine güven ve saygı duymalarına da yardımcı olmaktadır (San,1990). Ayrıca yaratıcı drama sürecindeki bu etkinliklere katılım gösterildiğinde iletişim sürecinde önce kendi düşüncelerimizin, duygularımızın ve bedenimizin farkına varırız. Bir durum, olay ya da kişi karşısında neler düşündüğümüzü inceleme olanağı buluruz. Benzer biçimde bir durum, olay ya da kişi karşısında duygularımızın, tutumlarımızın, değer yargılarımızın, alışkanlıklarımızın vb. neler olduğunu gözlemleyebiliriz (Oğuz ve Altun, 2011). Bu ve benzeri sonuçların elde edilmesinde en önemli etken ise yaratıcı drama süreçlerinde öğrenilen bilgilerin her zaman yeni bir bakış açısıyla değerlendirilmesi, deneyimler ve yaşantılarla gözden geçirilerek yeniden yapılandırılmasıdır (San, 2006). Söz konusu bu süreç, katılımcıların kendilerini ifade etmelerine ve yaratıcı doğaçlama uygulamaları yapmalarına fırsat tanıyan, öğrenci merkezli bir yaklaşım ve son derece etkili bir form olarak ifade etmelerine imkan verir (Winston, 2002). Drama ve doğaçlama çalışmaları, bireylere yaşadıkları dünyaya uyum sağlama ve karşılaşacakları sorunlarla 
mücadele etme firsatı tanıyan ve yaparak yaşarak öğrenme imkânı sağladığı için öğrencilerin hem duyuşsal hem de bilişsel olarak gelişimini olumlu etkilemektedir. Drama sürecinde bireyin düşüncelerinin, duygularının, bedeninin farkında olması, fikirler ve düşünceler geliştirmesi, etkileşim becerileri ve duyu organlarını kullanması çoğu zaman yaratıcı bir şekilde zihinsel resimlerini ve gerçeğin temsillerini yeniden şekillendirmektedir (Üstündağ, 2006; Toivanen, Komulainena ve Ruismäkia, 2011). Bunların yanısıra Pinciotti (1993) ve Yazar, Çelik ve Kök (2010) yaratıcı dramada öğrencilerin oyunlar, canlandırmalar ve rol oynama sırasında özellikle de değerlendirme aşamasında kendilerini daha rahat ifade ettiklerini, dünya hakkındaki bilinçlerinin ve çevreleri ile iletişimlerinin geliştiğini söylemekte ve yaratıcı dramanın bireyleri sanatsal açıdan daha duyarlı hale getirdiğini belirtmektedirler.

Yaratıcı drama etkinlikleriyle işlenen derslerde öğretmenin rolü ise hazır bilgi vermek yerine, öğrencilerin yeni bilgileri keşfetmelerine, yapılandırmalarına ve anlamlandırmalarına yardımcı olmak, bu tür bilgiler hakkında konuşmaları için ortam ve firsat yaratmaktır. (Andersen, 2000).

Yukarıdaki çerçeve doğrultusunda dramanın genel amaçları; yaratıcılığı ve hayal gücünü geliştirme, kendini tanıma, gerçekleştirme ve başkalarıyla iletişim becerisini geliştirme, demokratik tutum ve davranış geliştirme, estetik davranışlar geliştirme, eleştirel ve bağımsız düşünebilme becerisini geliştirme, işbirliği yapabilme, birlikte çalışma becerisi geliştirme, sosyal duyarlık yaratma, duygusunun sağlıklı bir biçimde boşalımı ve kontrolü, dil gelişimi, sözel ve sözel olmayan ifade becerisi eleştirel düşünme yeteneği, sosyal gelişim ve birlikte çalışma yeteneği kazandırma, bireylerin etik değerleri keşfetmelerine olanak sağlama, kendine güven duyma, teşvik ve karar verme, imge dünyasını geliştirme geliştirme olarak sıralanmaktadır (Adıgüzel, 2000; Adıgüzel, 2013)

Alanyazın incelendiğinde ise dramanın öncelikle kişilerin bireysel ve sosyal gelişimlerine iletişim, dil ve kendini ifade etme becerileri, yaratıcı düşünme, problem çözme, özgüven, işbirliği, kendini tanıma ve anlama, paylaşma, duyarlılık, empati, estetik hayal gücü gibi boyutlarda katkıları olduğu belirtilmektedir (Annarella, 1992; Metin, 1999; Okvuran, 2000; Akoğuz, 2002; Dikici, Koç ve Gündoğdu, 2003; Köksal Akyol, 2003; Yeğen, 2003, Turner, Mayall, Dickinson, Clark, Hood, Samuels, 2004; Demir, 2012; Taşar, 2012; Özşenler, 2013; Bütün, Tüzüner ve Duman, 2015). Sözü edilen bu katkılarının dışında alanyazındaki bazı çalışmalarda yaratıcı dramanın ayrıca, duyuşsal alanda tutumları etkilediği (Hurd, 1991; Yılmaz, 2015); çeşitli değerlerin kazandırılmasında da etkili olduğu (Aya, Günay ve Aydın, 2016) öğrencilerinin istikrarlı bütünlüğünün gelişimini sağladığ1 (Rusilowski, 2017) vurgulanmaktadır.

\section{Araştırmanın amacı}

Alanyazında yapılan araştırmalar incelendiğinde yaratıcı drama yöntemi, yaşantılara dayalı zengin bir öğrenme ortamı oluşturarak öğrencinin etkin bir şekilde öğrenme sürecine katılımını sağlayan, öğrenme mekânını sadece okul ve sınıfla sınırlamayan, etkili bir iletişim ve etkileşime imkan yaratarak öğrenci kazanımlarını ve başarısını üst düzeye çıkarabilecek bir yöntem olarak ön plana çıkmaktadır. Bu çalışmada Sosyal Bilgiler Öğretmenliği bölümündeki "İnsan İlişkileri ve İletişim” dersinde yaratıcı drama uygulamalarının "öğrenme, kişisel gelişim, mesleki gelişim, duygular, sosyal ilişkiler, değerler” boyutlarındaki etkilerine ilişkin öğrenci görüşlerinin belirlenmesi amaçlanmıştır. $\mathrm{Bu}$ amaca ulaşmak için İnsan "İlişkileri ve İletişim dersinin işlenişinde kullanılan yaratıcı drama etkinliklerine ilişkin öğretmen adayı öğrencilerin görüşleri nelerdir?” araştırma sorusu altında aşağıdaki sorulara yanıt aranmıştır: 
1. Yaratıcı drama etkinliklerinin iletişim dersine katkısına ilişkin öğretmen adaylarının görüşleri nelerdir?

2. Yaratıcı drama etkinliklerinin arkadaşlık ilişkilerine katkısına ilişkin öğretmen adaylarının görüşleri nelerdir?

3. Yaratıcı drama etkinliklerinin öğretmenlik becerilerine (ders işleme becerilerine) katkısına ilişkin öğretmen adaylarının görüşleri nelerdir?

4. Yaratıcı drama etkinliklerinin ders içi öğretmen-öğrenci etkileşimine katkısına ilişkin öğretmen adaylarının görüşleri nelerdir?

5. Yaratıcı drama etkinliklerinin diğer insanlarla ilişkilere olan katkısına ilişkin öğretmen adaylarının görüşleri nelerdir?

6. Yaratıcı drama etkinliklerinin duygulara katkısına ilişkin öğretmen adaylarının görüşleri nelerdir?

$\mathrm{Bu}$ altı soru 1şığındaki veri toplama sürecinde öğretmen adaylarının gerçekçi görüşleri yansıttıkları kabul edilerek araştırma bu varsayım üzerinde temellendirilmiştir.

\section{Yöntem}

\section{Araştırma Modeli}

$\mathrm{Bu}$ araştırmada deneysel modelin deneme öncesi desenlerden olan tek grup (kontrol grupsuz) öntest-sontest deneysel araştırma deseni kullanılmış ve araştırma verileri görüşme yoluyla elde edilmiştir. Neden-sonuç ilişkilerini gözlemek amacıyla araştırmacının kontrülünde uygulamaları gerçekleştirilen desenlerden biri olan tek grup öntest-sontest desende; bağımsız değişkenin uygulanmasından önce ve sonra ölçme işlemleri yapılır. Bu bu ölçmeler arasında ise denel işlem uygulanır (Karasar, 2003; Büyüköztürk, Kılıç Çakmak; Erkan Akgün, Karadeniz, Demirel, 2011). Söz konusu deneysel desenin ve veri toplama yönteminin uygulanması Şekil 1.de gösterilmiştir.

\begin{tabular}{|c|c|c|c|}
\hline Grup & Öntest & İşlem & Sontest \\
\hline \multirow[t]{3}{*}{ Tek grup } & Ön görüşme & İnsan ilişkileri ve İletişim dersinde yaratıcı & Son görüşme \\
\hline & (Yapılandırılmamış & drama etkinlikleri & (Yapılandırılmamış \\
\hline & Görüş alma formu) & & Görüş alma formu) \\
\hline
\end{tabular}

Şekil 1. Çalışmada Kullanılan Araştırma Modeli ve Veri Toplama Yöntemi

\section{Çalışma grubu}

Araştırma, 2016-2017 öğretim yılı bahar döneminde Mehmet Akif Ersoy Üniversitesi Eğitim Fakültesi Sosyal Bilgiler Öğretmenliği 3. sınıfında okutulan "insan ilişkileri ve iletişim” dersini alan 21 erkek, 33 kadın olmak üzere toplam 54 öğrenci ile gerçekleştirilmiştir. Uygun örnekleme (çalışma grubunun seçimi) koşulların ne olduğuna bağlıdır. Zamana, paraya, yere, konumun kullanılabilirliğine ya da cevaplayanlara dayalı örneklem seçebilir (Merriam, 2013). Bu çalışmadaki uygulamalar ders etkinliği çerçevesinde ve sınıftaki tüm öğrencilerin katılımını gerektirdiğinden dolayı kolay ulaşılabilir örneklem yöntemi tercih edilmiştir. 


\section{Veri Toplama Aracı}

Çalışmanın verileri yapılandırılmamış açık uçlu sorulardan oluşan bir görüşme formu ile toplanmıştır. Uygulama öncesi ve uygulama sonrasında kullanılan bu görüş alma formunda yaratıcı drama lideri, eğitim programları ve öğretim ve ölçme-değerlendirne alanlarında iki uzmanın görüşleri doğrultusunda geliştirilen ve araştırmanın amacı bölümünde belirtilen altı soruya yer verilmiştir. Çalışma öncesinde öğrencilere sınıf içi arkadaşlık ilişkileri, diğer insanlarla olan iletişimleri, ders hocalarıyla olan ilişkileri, derslerin öğretmenlik becerilerine katkılarına ilişkin görüşleri sorulmuştur. Çalışma sonunda da benzer sorularla oluşturulmuş form tekrar uygulanmıştır.

\section{Uygulama Süreci}

İnsan ilişkileri ve iletişim dersinin yaratıcı drama ile işlenebileceğinin uzmanlar yardımıyla kararlaştırılmasından sonra 12 hafta süren dersler için Tablo.1'de verilen konularda 2'şer ders saatlik atölye planları hazırlanmıştır.

Çalışmanın hemen başında tüm öğrencilerin sınıf içi ilişkiler ve iletişim hakkındaki düşünceleri yazılı olarak alınmıştır. Daha sonra dersin içeriği ve dönem boyunca yapılması planlanan uygulamalara ilişkin öğrenciler bilgilendirilmiştir. Bu çerçevede öğrencilerden beklenen tutum ve davranışlar açıklanmış, kendilerinin de beklentilerini dile getirmeleri sağlanmıştır. Bu tartışmalarda ortaya çıkan istek ve beklentiler doğrultusunda atölye planları tekrar gözden geçirilerek planlarda gerekli düzenlemeler yapılmıştır.

Çalışma kapsamındaki uygulamalar Mehmet Akif Ersoy Üniversitesi Sağl1k Kültür ve Spor Dairesine ait Avşar Han'daki çok amaçlı Salon-2 de gerçekleştirilmiştir. Çalışma süresince işlenen konuların akışı Tablo 1'de verilmiştir:

Tablo 1. Insan Illişkileri ve İletişim Ders Konuları ve Yaratıcı Drama Atölyeleri

\begin{tabular}{|l|l|l|}
\hline Ön görüşme & 5. İletişim ilkeleri & 9. İletişim çatışmaları ve çözüm yolları \\
\hline 1. Tanışma & 6. İetişimin niteliği & 10. İletişis çatışmaları ve çözüm yolları \\
\hline 2. Uyum-güven & Ara değerlendirme & 11. İletişimde dil \\
\hline 3. İletişim kavramı & 7. İletiş̧im engelleri & 12. Dinleme becerileri ve iletişim \\
\hline 4. İletişim ögeleri & 8. İletişim engelleri & Genel değerlendirme \\
\hline
\end{tabular}

Tablo 1'de görülen atölye konuları yaratıcı drama aşamaları (1sınma, canlandırma ve değerlendirme) doğrultusunda planlanarak 12 hafta boyunca 2'şer ders saati (toplam 90'ar dk.) olarak bizzat araştırmacı tarafından uygulanmıştır.

\section{Verilerin Analizi}

Yukarıda özellikleri açıklanan veri toplama aracıyla alt problemler doğrultusunda katılımcılardan yazılı olarak toplanan veriler 353 sayfalık bir veri seti oluşturmuştur. Her bir katılımcının yazılı görüş alma formuna verdikleri cevaplar madde madde incelenmiştir. Her maddeye ilişkin kodlar belirlenmiştir. Ortak olan kodlar bir araya getirilmiş ve 6 ana tema altında toplanmıştır. Her bir koda ilişkin görüşlerin frekans ve yüzdeleri alınarak bulgular tablolar üzerinden yorumlanmiştır. 


\section{Bulgular ve Yorum}

Verilerin analizi sonucunda uygulama öncesindeki grubun iletişim özellikleri ile uygulama sonrasında iletişimle ilgili öğrenmelerine ilişkin temalar Tablo 2' de verilmiştir:

Tablo 2. Öğrencilerin Uygulama Öncesi ve Uygulama Sonrasında İletişim Özellikleri ve İletişimle Ilgili Ögrenmeleri

\begin{tabular}{|c|c|c|c|c|c|}
\hline \multicolumn{3}{|c|}{ Uygulama Öncesi Temalar } & \multicolumn{3}{|l|}{ Uygulama Sonrası Temalar } \\
\hline I. İletişim Teması & f & $\%$ & İletişimi Öğrenme & f & $\%$ \\
\hline \multirow{3}{*}{$\begin{array}{l}\text { 1. Olumsuz öğrenci- Öğrenci } \\
\text { İletişimi } \\
\text { (Zayıf/kopuk iletişim) }\end{array}$} & \multirow{3}{*}{54} & \multirow{3}{*}{100} & 1. Olumlu iletişim kurma (konuşma) & 50 & 93 \\
\hline & & & $\begin{array}{l}\text { 2. Öğretmen-öğrenci iletişiminin nasıl olması } \\
\text { gerektiğini }\end{array}$ & 50 & 93 \\
\hline & & & 3. İletişim çatışmaları çözmeyi öğrenme & 45 & 83 \\
\hline $\begin{array}{l}\text { 2. Öğretim elamanı- öğrenci } \\
\text { etkileşimi (İletişim yokluğu) }\end{array}$ & 50 & 93 & $\begin{array}{l}\text { 4. İletişimde beden dili (jest mimik, göz } \\
\text { teması, ses tonu, yüzüne bakarak konuşma } \\
\text { vb.) }\end{array}$ & 44 & 81 \\
\hline 3. Öğrenciler arası gruplaşma & 52 & 96 & $\begin{array}{l}\text { 5. Problemleri (sorunları) fark etme ve } \\
\text { farkındalık kazanma }\end{array}$ & 43 & 80 \\
\hline 4. Dinlememe ve anlamama & 50 & 93 & 6. İletişim araçları (yolları) & 41 & 76 \\
\hline 5. Duyarsızlık- umursamazlık & 40 & 74 & 7. İletişim ve ilişkileri güçlendirme & 39 & 72 \\
\hline \multirow{2}{*}{ 6. Yalnızlık ve yalnızlık tercihi } & \multirow{2}{*}{30} & \multirow{2}{*}{56} & 8. İletişim engelleri & 38 & 70 \\
\hline & & & 9. Teknolojinin kötü kullanımı ve önlem alma & 5 & 9 \\
\hline
\end{tabular}

Tablo 2'de görüldüğü gibi uygulama öncesindeki grubun iletişim temasının özellikleri konusunda öğrencilerin tamamı öğrenci-öğrenci iletişiminin olmadığını ya da çok yetersiz olduğunu; \% 93'ü öğretim elemanı-öğrenci etkileşiminin olmadığını; \%96'sı sınıfta gruplaşmaların olduğunu belirtmişlerdir. Sınıf içi ve günlük yaşamdaki insan ilişkileri ile ilgili olarak katılımcıların \%93’ü dinlememek ve anlamamak üzerine kurulduğunu; \% 74'ü duyarsızlık davranışlarının olduğunu ve \% 56 'sı bireylerin yalnızlığı tercih ettiğini vurgulamıştır.

Uygulama sonrası iletişimle ilgili öğrenmeler temasında ise çalışma grubunun \% 93’ü iletişim kurmay1, öğretmen-öğrenci iletişiminin nasıl olması gerektiğini ve iletişim çatışmalarını çözmeyi öğrendiğini belirtmektedir. Ayrıca katılımcıların \% 81’i iletişimde beden dilinin (jest mimik, göz temas1, ses tonu, yüzüne bakarak konuşma vb.) ne kadar önemli olduğunu; \% 80’i iletişimle ilgili sorunları fark etme konusunda farkındalık kazandıklarından söz etmektedir. Yine bu tema ile ilgili olarak katılımcıların \% 76'sı iletişim araç ve yollarını, \% 72'si iletişim ve ilişkileri güçlendirmede neler yapılması gerektiğini, \% 70'i iletişim engellerinin neler olduğunu öğrendiğini ifade ederken \% 9'u ise teknolojinin kötü kullanımından ve bu duruma karşı önlemler alınması gerektiğinden bahsetmektedir.

Katılımcı görüşlerine göre uygulama öncesindeki grubun sahip oldukları iletişim özellikleri, hem iletişim sürecini oldukça olumsuz etkileyen etkenler olması hem de büyük oranda gözleniyor olması dikkat çekici bir durumken; uygulama sonrasında çalışma grubunun iletişimle ilgili kavram, özellik ve süreçlere ilişkin öğrenmelerin oldukça üst düzeyde gerçekleştiği sonucuna ulaşılmıştır. İletişim özellikleri ve iletişimle ilgili öğrenmeler konularında elde edilen öğrenci görüşlerinden örneklere yer verilmiştir: 
“...iletişim sorun ve çatışmalarının yaşanmaması için öğretmenlerin bu alanda kendini geliştirmesi gerektiğini anladım ...” (ö7,ö9,ö22)

“...iletişsim engelleri ve çatışmalarıyla karşılaştığımda nasıl bir yol izlemem gerektiğini ögretti...”(ö23, ö37)

“...iletişsimin dinleme ile başladığını öğrendim... ”(ö14, ö29, ö51)

“...insan ilişkilerinde sorun yaratan iletişim engellerinin neler olduğunu daha iyi anladım... ”, (ö5)

“...insanlarla konuşma tarzımıza, jest ve mimiklerimize dikkat etmem gerektiğini öğrendim... ” (ö11, ö19, ö21,ö29,ö 32, ö46, ö54)

“...dinlemiyoruz, empati yapmiyoruz vb. birçok iletişim sorunların yaratıyoruz. Ama hala kendimizin doğru olduğuna inanıyoruz, yanlışlarımızı görmek istemiyoruz. Ancak önyargılarımızdan kurtulduğumuzda insanların farklı olduğunu ve olduğu gibi kabullenmeyi ögrendiğimizde bu sorunların ortadan kalkacağına inaniyorum. Konuşamayarak çözülemeyecek bir sorun kesinlikle yoktur.” (ö10,ö15,ö30,ö36)

“...Ön yargllarımız insanların dış görünüşüne, klyafetine, cinsiyetine, ırkına dinine, siyasi görüşüne, kültürüne o kadar baklyor ve yorumluyoruz ki insanın özüne, karakterine bakmayl unutuyoruz. (ö4,ö13,ö17,ö34)”

“...bu dersin sonucunda fark ettim ki bütün insanlarla kurduğum ilişkilerde hep bir hata hep bir yanlış var, başarılı insan ilişkileri bence ilk olarak insanları ve onların doğasını doğru anlamaktan geçer, insanların belli koşullar altında neden ve nasıl tepki gösterdiklerini anladı̆̆ımız zaman ancak düzgün iletişim kurabiliriz." (ö7, ö29)

“...birbirimizi kirlp gergin bir ortam yaratmak yerine birbirimizi sevip bir birimizle konuşarak oluşan problemlerin ortadan kalkacağını öğrendim.” (ö9, ö14, ö26, ö37)

“...insanlar hakkında oluşturduğumuz önyargılardan, koyduğumuz katı kurallarımızdan var olan problemlerden vazgeçtiğimizde sağllklı bir iletişsim sağlandiğını gördüm bunu yolu ise birbirimizi dinlemekten geçer.” (ö9, ö12, ö46)

“...bu dersi almadan önce nelerin iletişim engeli olduğunu bilmiyordum. ” (ö14,ö23,ö28,ö3 3,ö34,ö38,ö42,ö47,ö51,ö52) 
Tablo 3. Uygulama Öncesi ve Uygulama Sonrası Öğretme-Öğrenme Ortamında Kazandıkları Mesleki Beceriler ile İlgili Görüşleri

\begin{tabular}{|c|c|c|c|c|c|}
\hline \multicolumn{3}{|l|}{ Uygulama Öncesi Temalar } & \multicolumn{3}{|l|}{ Uygulama Sonrası Temalar } \\
\hline Gözlenen mesleki beceriler & f & $\%$ & Öğretim sürecinin aşamaları & f & $\%$ \\
\hline 1. Anlatım yöntemi ve ezberleme & 42 & 77 & \multirow{3}{*}{$\begin{array}{l}\text { 1. Derse hazırlık } \\
\text { - Derse giriş ve ısınma } \\
\text { - İlgi ve dikkati artırma (hareketlilik) } \\
\text { - Öğrencileri güdüleme (Öğrenmeye } \\
\text { isteklendirme) }\end{array}$} & \multirow{3}{*}{52} & \multirow{3}{*}{96} \\
\hline $\begin{array}{l}\text { 2. Önceki eğitim yaşantıları ve } \\
\text { pasiflik }\end{array}$ & 42 & 77 & & & \\
\hline 3. Çekingen ve pasif öğrenci & 40 & 74 & & & \\
\hline 4. Resmi - formal bir ortam & 40 & 74 & \multicolumn{3}{|l|}{ 2. Öğretme-öğrenme etkinliklerinin niteliği } \\
\hline \multirow[t]{18}{*}{ 5. Tek düze eğitim } & 40 & 74 & - Yaparak-yaşayarak öğrenme & 52 & 96 \\
\hline & & & - Materyal kullanma & 51 & 94 \\
\hline & & & - Etkili iletişim & 50 & 93 \\
\hline & & & - Öğrenmeyi kolaylaştırma & 50 & 93 \\
\hline & & & -Öğrenmeyi oyunlarla destekleme & 50 & 93 \\
\hline & & & $\begin{array}{l}\text { - Öğretimde çeşitlilik yaratma (farklı } \\
\text { öğretme-öğrenme yolları kullanma }\end{array}$ & 48 & 89 \\
\hline & & & - Öğrenmedeöğrenci aktifliği & 48 & 89 \\
\hline & & & - Yöntem - teknik seçimi ve kullanımı & 46 & 85 \\
\hline & & & - Öğrenme firsat ve imkân yaratma & 42 & 77 \\
\hline & & & - Öğrenci seviyesine uygunluk & 41 & 76 \\
\hline & & & - Özgür ve kontrollü ortam & 39 & 72 \\
\hline & & & - Kitaba bağlı kalmama & 26 & 48 \\
\hline & & & $\begin{array}{l}\text { 3. Değerlendirme ve dönüt işlemleri } \\
\text { niteliği }\end{array}$ & 45 & 83 \\
\hline & & & 4. Olumlu öğretmen tutumları & 35 & 65 \\
\hline & & & 5. Öğretmenlik mesleğini sevme & 33 & 61 \\
\hline & & & 6. Yaratıcı ve özgün düşünme & 32 & 59 \\
\hline & & & $\begin{array}{l}\text { 7. Öğretimde mekan (sınıf dış1 } \\
\text { mekanlar) }\end{array}$ & 25 & 46 \\
\hline & & & 8. Sınıf oturma planı (düzeni) & 23 & 42 \\
\hline
\end{tabular}

Tablo 3' te görüldügü gibi uygulama öncesi elde edilen verilerde öğretme-öğrenme ortam1 ilgili mesleki beceriler konusunda öğrencilerin \% 77'si süreçle ilgili yaşantılarında anlatım yöntemi, ezberleme ve öğrenci pasifliğinden; \% 74' ü ise resmi bir ortamın ve tek düze eğitim uygulamalarının varlığından söz etmişlerdir.

Çalışma sonunda ise bu süreçteki mesleki becerilerle ilgili olarak öğretmenlik mesleğine başladıktan sonra öğrencilerin \% 96'sı öğretim sürecinin giriş etkinliklerindeki (1sınma, dikkat çekme, güdüleme vb.) gibi yapılması gerekli olan uygulamaları yerine getireceklerini ifade etmişlerdir. Süreçte ise öğrencilerin \% 96's1 yaparak-yaşayarak öğrenmeye ve materyal kullanmaya ağırlık vereceklerini; \% 94'ü etkili iletişimi sağlamaya özen göstereceklerini belirtmişlerdir. Katılımcıların \% 93’ü öğrenmeyi kolaylaştırma ve oyunlarla destekleyeceklerini, farklı öğretme-öğrenme yolları kullanarak öğretimde çeşitlilik sağlayacaklarını; \% 89’u hem öğrenme sürecinde öğrencinin aktif 
olmasını sağlama konusunda hem de yöntem-teknik seçimi ve kullanımında daha dikkatli olacağını dile getirmiştir. Yine öğrencilerin \% 85'i öğrenmede firsat ve imkân yaratacağını, \%77'si öğrenci seviyesine uygun uygulamalar yapacağını; \% 76'sı özgür ve kontrollü ortam sağlayacağını; \% 26's1 kitaba bağlı kalmayacağını; \% 83'ü ise değerlendirme ve dönüt işlemlerini gerektiğinde yapacağını vurgulamıştır.

Yukarıdaki temaların yanı sıra öğretme- öğrenme sürecinde ele alınan farklı temalar da ortaya çıkmıştır. Bu çerçevede öğrencilerin \% 65’i olması gereken öğretmen tutumlarını sergileyeceklerini; \% 61'i öğretmenlik mesleğini seveceğini, \% 59'u yaratıcı ve özgün düşünme ortamı sağlayacağını \% 46'sı mekân sınırlaması olmadan her yerde ders işlenebileceğini ve \% 42'si ise sınıflarında belli bir orturma planı ve düzeni oluşturmayacaklarını ifade etmişlerdir.

Katılımcıların bu tema ile ilgili düşünceleri uygulama öncesinde -ders öğretim elemanlarıyla ilgili yaşantılarından dolayı- daha sınırlıyken ve büyük oranda geleneksel ve öğretmen merkezli eğitim uygulamalarını yansıtırken; uygulama sonrasında ise öğretmen olduktan sonra sergileyecekleri davranışlarla ilgili düşünceler açısından hem çeşitlilik göstermekte hem de oran bakımından zenginleşerek öğrenci merkezli eğitim uygulamalarına ilişkin olumlu bir bakış açısı yansıtmıştır. $\mathrm{Bu}$ tema ile ilgili öğrencilerin görüşlerinden bazı örnekler aşağıda verilmiştir:

“...drama ile birlikte derste daha hareketli ve daha dikkat çekici olmayı öğrendim. Kitaba bağlı kalmamayı ve çeşitlilik sağlamayl, çeşitli oyunlarla dersi daha verimli hale getirmeyi ögrendim." (ö2,ö14)

“...çok sayıda duyu organını kullanarak yaparak yaşayarak öğrenme imkânı veren ve çok çeşitli tekniklerle öğrenme imkânın sağlanması öğrencinin daha aktif, ezberden uzak eğlenceli hem de kalıcı şekilde öğrenmesini sağllyor.” (ö8, ö13,ö17,ö42,ö51)

“...dersin sadece kitaplardan ibaret olmadığını.” (ö4,ö32)

“...öğreticinin öğrenciye hem ahlaki hem de manevi açıdan örnek teşkil etmesi dışında drama ortamında kişisel becerilerini ve yeteneklerini sergileme imkânı bunulması ögrencilerin daha çok dikkatini çeker ve hayranlık uyandırır."(ö8, ö11,ö49)

“...bask altında işlenen bir dersten yeterince verim olmaz, o derse odaklanamaz, dersi anlamaz, hatta dersten ve ögretmeninden soğuyabilir.”(ö12,ö36,ö52)

“...dersin sonunda değerlendirme aşamasında herkesin birbirini görebileceği şekilde oturup bugün etkinliklerden ne anladı, ne işledik sorulartyla ders hakkında sorular sorarak dönütler alınması, ögrenmenin zamanında kontrol edilmesini sağlamaktadır. Dönütler slnavlarda alındiğında hem uzun bir zaman dilimi araya girmekte hem de ögrenmede sorunlar yaratmakladır." (ö6,ö18,ö53)

“...oynayarak- yaşayarak- eleştirerek-tartışarak öğrenmemizi sağladı, öğrenmeler bu şekilde daha kalıcl ve birbirinin üstüne yığılmamaktadır.” (ö6,ö12,ö24,ö35,ö48)

“...eğer öğretmenimiz düz anlatım yöntemini seçip dersini anlatsaydı aktiflik, bireyler arası etkileşimimiz ve duyarlılı seviyesi daha alt düzeyde olurdu, tanımları ve bilgileri ezberlerdik. "(ö6,ö12, 28,ö37,ö54)

“... bize yeni bir ufuk açtı. Sinıfa gelip defteri açıp iletişsim şudur, insan ilişkileri budur diye yazdırmak ve yazmaktan ibaret olmadlğın aslında o şekilde bir yöntemin bize hiçbir fayda sağlamadığını öğretti, bu yöntem bizi dersin içine aldı ve bizi gerçekten o dersin ögesi yapt.."(ö15,ö17,ö51) 
İnsan İlişkileri ve İletişim Dersinde Yaratıcı Drama Uygulamalarının Etkisine İlişkin Öğrenci Görüşleri

“...e ğitimini alıp da ögrrendiğim birçok öğretim yöntemi var; elbetteki her yöntemin de kullanıldiğl, etkili olduğu konular vardır. Hangi konunun hangi yöntemle işlenmesi gerektiği, hangi yöntemle işlenirse etkili olacă̆ öğretmenin bilecĕgi iştir, bende öğretmen olduğumda hangi konunun hangi yöntemle işlenmesi gerektiğimi dikkate alarak hareket edeceğim. Öğretmenlik hayatımda birçok yöntem kullanmam gerekecek.” (ö12,ö14,ö15,ö17, $\ddot{o} 25, \ddot{o} 29, \ddot{o} 44)$

“...öğrencimle aramda olan ilişkiyi belirli bir seviye de tutmayı kendime hedef edineceğim, çünkü başarılı ve her zaman daha da ögrrenme isteği olan ögrenci grubunun yaratılmasının ögretmen öğrenci ilişkilerinden geçtiğini düşünüyorum.” (ö12,Ö13,ö14, ö17, ö41)

“...öğretmen olduğumda işe ilk olarak sınıfta var olan oturma planını değiştirmekle işe başlarım, çünkü mevcut oturma planlarl ögrencilerin gruplaşarak birbirlerinden habersiz ve

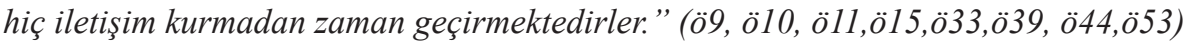

“...̈̈grencilerin fikirlerini özgürce söyleyebilecekleri bir ortam yaratmaya çalışırım.”

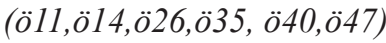

“...oturma düzeni olarak $U$, çember ve etkinlik alanları olacak şekilde düzenleme yapmaya çalışırım.” (ö9,ö17,ö21,ö38,ö52,ö54)

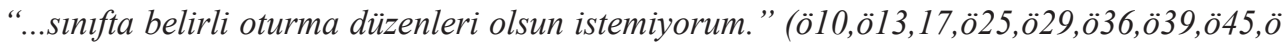
51)

“...ögrrencilerin yerlerini sürekli değiştirerek gruplaşmaları önler, arkadaşlık bă̆larını kuvvetlendirebilirim.” (ö2,ö6, ö9, ö12, ö33, ö43, o54)

“...ders dışında iletişimle ilgili oyunlar oynatıp onlara sağlıklı bir iletişimin nasıl olması gerektiğini anlatırım.” (ö7, ö14, ö31,̈37,ö43,ö52)

“...iletişimi güçlendiren sosyal aktiviteler yaparak öğrencilerimle arkadaş olabileceğimi, onlarlailetişimkurarakdersleridahaverimli işleyebileceğimi, dikkatlerinitoplayabileceğimi. ' (ö5, ̈9, $21, \ddot{o} 29, \ddot{o} 38, \ddot{o} 46)$

“...drama başta olmak üzere farklı yol ve yöntemleri kullanacağım. Sınıf ortamını düzenleme ve hakimiyet açısından oldukça faydall. Farklı materyal ve araç gereçlerden faydanırım. Bunları da ögrencilerin kapasitesine ve bilgilerine göre uygularım. Ses tonumu farklılaştırarak ve öğrencinin yüzene bakarak ders işlerim.” (ö3,ö10,ö16,ö35,ö49)

“...gruplaşmaları önlemek adına her daim farklı kişilerle oturmalarını ve iletişim kurmalarını sağlarım” (ö8,ö43)”

“...bir ögrenci sınıftan ne kadar rahat olursa ve sınıfını ne kadar çok severse ders de o kadar istekli gelir.” (ö8)

“...materyallerle donatırım sınıfi ve onları korkmadan paylaşırım.” (ö6, $\ddot{o} 11, \ddot{o} 14, \ddot{o} 19, \ddot{o} 29, \ddot{o} 36, \ddot{o} 50)$ 
Tablo 4. Öğrencilerin Uygulama Öncesi ve Sonrasında Kişisel Özelliklerdeki Gelişim ile İlgili Görüşleri

\begin{tabular}{|c|c|c|c|c|c|}
\hline Uygulama Öncesi Temalar & $\mathbf{f}$ & $\%$ & Uygulama Sonrası Temalar & $\mathbf{f}$ & $\%$ \\
\hline 1. Kişisel özellikler & & & 1. Kişisel Özellikler & & \\
\hline - Empati yokluğu & 52 & 96 & - Özgüven duyma, & 52 & 96 \\
\hline \multirow[t]{18}{*}{ - Çekingen ve pasif olma } & 50 & 93 & - Sosyal girişimcilik / Girişkenlik & 48 & 89 \\
\hline & & & - Kendini ve yeteneklerini tanıma & 40 & 74 \\
\hline & & & - Cesaret & 38 & 70 \\
\hline & & & 2. Dil becerileri & & \\
\hline & & & - Kendini ifade etme & 44 & 81 \\
\hline & & & - Soru sorma & 43 & 80 \\
\hline & & & - Dinleme & 38 & 70 \\
\hline & & & 3. Düşünme becerileri & & \\
\hline & & & - Düşünme, fikir üretme & 40 & 74 \\
\hline & & & - Empati kurma becerisi & 36 & 67 \\
\hline & & & - Yaratıcı ve özgün düşünme & 35 & 65 \\
\hline & & & - Araştırma, bulma ve anlatma yeteneği & 32 & 59 \\
\hline & & & - Anlık cevap ve tepki (hazırcevaplılık) & 28 & 52 \\
\hline & & & 4. Davranış gelişimi açısından & & \\
\hline & & & - Doğal olma & 23 & 43 \\
\hline & & & - Sabır ve tahammül gösterme & 21 & 39 \\
\hline & & & - Kendini (duygularını, tepkilerini) kontrol etme & 18 & 33 \\
\hline & & & 5. Bedensel gelişim ve aktiflik & 13 & 24 \\
\hline
\end{tabular}

Tablo 4’te görüldüğü gibi kişilik özellikleri olarak uygulama öncesinde öğrencilerin \% 96’s1 empati yokluğundan, \% 93'ü ise çekingenlik özelliğinden dolayı pasif kalmaktan söz etmişlerdir. Öte yandan yine aynı tabloda uygulama sonrası kişilik gelişimi özellikleri ilgili olarak öğrencilerin \% 96's1 özgüven kazandıklarını; \% 89'u çekinkenlikten kurtularak sosyal girişimciliklerinin arttığını, \% 74'ü kendini ve sahip olduğu yetenekleri tanıdığını ve \% 70'i ise cesaret kazandıklarını belirtmektedir. Bunların dışında düşünme becerileriyle ilgili olarak katılımcıların \%74'ü düşünme, fikir üretme; \% 67'si empati kurma; \% 65'i yaratıcı ve özgün düşünme becerilerinin; \% 59'u araştırma, bulma ve anlatma yeteneğinin; \%19'u ise anlık cevap ve tepki (hazırcevaplılık) özelliğinin geliştiğini ifade etmektedir. Ayrıca davranışları açısından katılımcıların \% 43'ü doğallık, \% 39’u sabır ve tahammül gösterme; \% 33’ü kendini (duygularını, tepkilerini) kontrol etme açılarından kendilerini geliştirdiklerini belirtirmektedir. Çalışmaların kendilerine bedensel gelişim ve aktiflik sağladı̆̆ını söyleyenlerin oranı ise $\% 24$ olarak belirlenmiştir

Katılımcıların kişisel özellikler temasında uygulama öncesindeki görüşleri iki özellikle sınırlı kalırken uygulama sonrasında bu tema ile ilgili belirtilen düşünce ve özellikler oldukça zenginleşmiş, hem kapsam hem de oran olarak büyük bir değişimi yansıtır hale gelmiştir. Öğrencilerin bu tema ile ileri sürdükleri görüşlerden bazıları örnek olarak aşağıda verilmiştir:

“...dikkat, konuşma, düsünme, üretme, kendini ifade etme gibi becerileri kazandırırdl." (ö3,ö8,Ö11, Ö18,ö26, ö34,ö40,ö42,ö53) 
İnsan İlişkileri ve İletişim Dersinde Yaratıcı Drama Uygulamalarının Etkisine İlişkin Öğrenci Görüşleri

“...empati becersi, karşımızdakini dinlemeyi kazandırdı (ö10, ö12, 17, ö19, ö23, ö28, ö35, $\ddot{o} 43, \ddot{o} 48, \ddot{o} 51)$

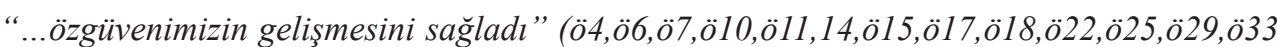
, $39, \ddot{0} 45)$

“...oldukça etkili bir ders işleme yöntemidir. Bu ders birbirimize daha hoşgörülü olmaya, kaynaştırmaya, konuşturmaya karşı bizi geliştirdi. Sınıfta yüz yüze bakmadı̆̆ım konuşmadığımı insanlarla bir araya gelme firsatı yarattı. Bu derste özellikle özgüven olarak kişiliğimi ön plana çıkarabilecĕ̆im, çekinmemem gerektiğini öğrendim.” (ö1)

“...ilerleyen derslerde utangaçlık, çekingenlik, korku yerini mutluluğa, eğlenceye, neye atılganlı̆̆a, özgüvene bırakt, kendimden emin davrandım. ”(ö12,ö39)

“...yaratıcı düşünceler geliştirmemizi, kendimizi ifade etme ve yeteneklerimizi geliştirme imkânı sağladı.” (ö1, ö5,ö35)

“...ders birbirimize karşı konuşmamızı, üslubumuzu, bakışımızı, gülü̈sümüzü bile değiştirdi, birbirimizle samimiyetimiz arttı.” (ö15,ö32)

“...doğaçlamalar bize meslek hayatımızda hazırcevaplılı̆̆ geliştirebilir.” (ö16)

“...doğaçlamalarda yeteneklerimizin farkına vardık. Illetişime istekli hale geliyoruz. ”(ö2,ö15

“...insanlara karşı daha sabırlı ve anlayışlı alınması gerektiğini kazandım.” (ö2,ö27,ö48)

“...yapmaktan utandı̆̆ımız ya da çekindiğimiz şeyleri daha rahat yapmaya başladık.”

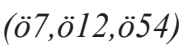

“...herkes bize bakarken çok rahat şekilde etkinliğimi gerçekleştirdim.” (ö1)

“...her şeyden önce konuşmanın yanı sıra karşımızdaki kişiye empati kurarak onun ne duruma düşeceğini ölçerek tartarak duygu ve düşüncelerimizi belirtmeye başladık. ”(ö7,ö21,ö53)

“...kendimi keşfetme şansı buldum, daha önce hiç bu tarz etkinliklerde bulunmamış hep uzak durmuştum toplumda aykırı hareket etmekten farklı hareketlerde bulunmaktan kaçınmıştım, artık doğal, içimden geldiği gibi davranabiliyorum.” (ö3)

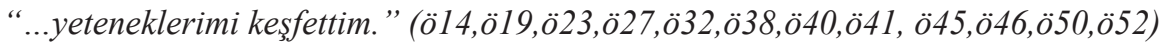

“...duygularımı kontrol etmeyi ögrendim, öfke ve sevinçlerimi heyecanımı nasıl kontrol

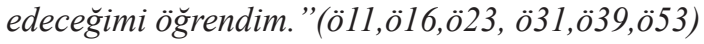

“...empatiyi kurarak insanların hangi durumlarda sevindiklerini ya da korktuklarinı anlamaya çalışıyorum. ”(ö11,ö48)

“...daha öncesinde sınıfımda veya günlük yaşamımda arkadaşlarımın, insanların yüzlerine bakmıyordum, oysaki iletişimde tüm bedenin mesaj verdiğini öğrendim. ”(ö14) 
Tablo 5. Öğrencilerin Uygulama Öncesi ve Sonrasında Değerler ile İlgili Görüşleri

\begin{tabular}{|c|c|c|c|c|c|}
\hline Uygulama Öncesi Temalar & $\mathbf{f}$ & $\%$ & Uygulama Sonrası Temalar & $\mathbf{f}$ & $\%$ \\
\hline 1. Değerler & & & 1. Değerler & & \\
\hline \multirow{2}{*}{ - Önyargıların olumsuz etkisi } & \multirow{2}{*}{52} & \multirow{2}{*}{96} & - Önyargısızlık (önyargılı olmama) & 54 & 100 \\
\hline & & & - İnsanları anlama çabası & 52 & 96 \\
\hline - Şekilcilik dış görünüş & 44 & 81 & - Demokratik davranma & 50 & 93 \\
\hline \multirow[t]{5}{*}{ - Cinsiyet ayrımcilığ 1} & 36 & 67 & - Hoşgörülü ve anlayışlı olma & 50 & 93 \\
\hline & & & $\begin{array}{l}\text { - Farklılıklara saygi duyma (Bireysel ve } \\
\text { kültürel farkl11ıklar) }\end{array}$ & 50 & 93 \\
\hline & & & - Gönüllü olma & 48 & 89 \\
\hline & & & - Paylaşma & 48 & 89 \\
\hline & & & - Sayg1 duyma & 47 & 87 \\
\hline
\end{tabular}

Tablo 5 incelendiğinde sahip olunan değerler temasında uygulama öncesi öğrencilerin \% 96'sı insan ilişkilerinde önyargılarının olumsuz etkisinden; \%81'i de şekilcilik ve dış görünüşe önem verdiklerinden ve \% 67'si ise cinsiyet ayrımcılığının etkisinde davrandıklarından söz etmişlerdir. Yine aynı tabloda görüldüğü gibi uygulama sonrasında katılımcıların tamamı insan ilişkileri ve iletişim sürecinde önyargılı olmamak gerektiğini; \% 96'sı insanları anlamak için çaba gösterilmesi gerektiğini, \% 93'ü ise demokratik davranılması, hoşgörü ve anlayış gösterilmesini, bireysel ve kültürel farklılıklara saygı duyma değerlerini kazandıklarını dile getirmişlerdir. Ayrıca katılımcıların \% 89'u gönüllülük ve paylaşma; \% 87'si ise saygı duyma davranış ve değerlerini kazandıklarını belirtmektedirler.

Öğrencilerin uygulama öncesinde değerler teması ile ilgili olarak sadece üç temel ve aynı zamanda olumsuz özelliklere büyük oranlarda sahip oldukları gözlenirken; uygulama sonrasında ise hem önceden sahip oldukları olumsuz değer anlayışlarının değiştiği hem de yeni kazandıkları değer özelliklerinin nicelik ve nitelik olarak olumlu yönde artış gösterdiği gözlenmiştir. Bu değerlerle ilgili öğrenci görüşlerinden bazı örnekler aşağıda verilmiştir:

“...biz o kadar çok birbirimizin memleketi, ırkl, cinsi, klyafet gibi özellikleriyle ilgilenmişiz ki konuşabileceğimiz ortak bir şeyler çok da güzel yapabileceğimiz birlikte eğlenebileceğimizi birlikte var olduğumuz unutmuşuz. Hatta en kötüsü nerdeyse üç yllın sonunda sinıftaki bazı arkadaşların isimlerini bile bilmediğimi fark ettim. O insanlarla iletişime geçtiğimde ortak bir payda içinde olduğumda eğlenebileceğimi konuşabileceğimi fark ettim. ”(ö4,ö11,ö48)

“...drama ile tabularımı yıktım, belli başlı kişilerle değil, herkesle konuşabileceğimi ögrendim.” (ö11,ö14,ö27,ö43)

“...herkesin kendine özgü hal ve hareketlerinin olabileceğini ve bunu kimsenin yadırgamam gerektiğini anlatırım.” (ö7)

“...hâlbuki her insan bir değer, her farklı insan bir deneyim, bir tecrübe ve ödül. Kendimizi başka insanlara kapattığımı sürece, ön yargılardan kurtulamadlğımız sürece...” (ö4, ö32,ö54)

“...kendimize karşı özgüvenimiz, arkadaşlarımıza karşı da güven duygumuzu artırmıştır. Grup etkinliklerinde fikirlerimizi ileri sürerken farkl özelliklere sahip olduğumuzu keşfettik bu farklılıklar dâhilinde paylaşmanın ve başarıya ulaşmanın tadını tattık. "(ö6,ö16,ö24,ö38,ö51) 
İnsan İlişkileri ve İletişim Dersinde Yaratıcı Drama Uygulamalarının Etkisine İlişkin Öğrenci Görüşleri

“...Duygularımın değiştiğini, hoşlanmadı̆̆ım insanlara karş̧ biraz daha ılımlı olmayl, bana uzak gelen ya da kafa yapılarımızın uyuşmayacağını düşündüğüm insanlara karşı." (ö4,ö33,ö49)

“... öncelikle insanlara önyargıyla yaklaşmamayl, onlar hakkında bilip bilmeden konuşmamayı dlş görünüşüne göre insanlarl yargılamamayı her kim olursa olsun insanlara karşı kibar, nazik ve iyi bir iletişim içinde olmalyyız." (ö11, ö15,ö22,ö27,ö39)

“...bazı şeyleri anlamamız için bazen kendimizi onun yerine koyup öyle davranmamız gerekir.” (ö7)

“...hepimizin farklı düşünceleri olabilir, bu iletişim kurmamıza bir engel değildir, insanları tanımadan, konuşmadan yaşamadan bilemeyiz, o yüzden ön yargılarımızı yıkıp insanlara öyle yaklaşmallyız."(ö4,ö9,ö17,ö52)

“...Insanlar her ne kadar faklı olsa da birbirlerinden her daim bir şeyler öğrenmeye açı olduklarında en azından bir yöreye ait kelime, yemek, şarkl, türkü hatta şive ögrenilirler, kültürel alışveriş sağlanır, ön yargılar bir kenara bırakılmalı.” (ö8)

“...Insanlara kendilerini tanıtmalarına izin vermem gerektiğini anladım.” (ö14,ö33)

Tablo 6. Öğrencilerin Uygulama Sonrası Sosyal Özellikleri ile Illgili Görüşleri

\begin{tabular}{|c|c|c|c|}
\hline \multirow{16}{*}{ 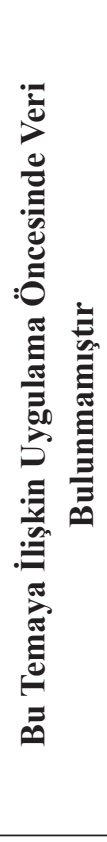 } & Uygulama Sonrası Temalar & $\mathbf{f}$ & $\%$ \\
\hline & 1. Sosyal gelişim & & \\
\hline & - Farklı insanlar /duygular vb. tanıma & 52 & 96 \\
\hline & 2.Etkileşimi artırma & & \\
\hline & - Samimiyet & 52 & 96 \\
\hline & - Kaynaşma (yakınlaşma) & 50 & 93 \\
\hline & - Gruplaşmaların azalması & 50 & 93 \\
\hline & - Yardımlaşma ve dayanışma & 50 & 93 \\
\hline & - Görüş paylaşımı (fikir alışverişi) & 48 & 89 \\
\hline & - İşbirliği & 48 & 89 \\
\hline & - Paylaşım & 47 & 87 \\
\hline & - Kişilere güven duyma & 46 & 85 \\
\hline & - Sosyalleşme & 46 & 85 \\
\hline & - Görev dağılımı ve paylaşımı & 43 & 80 \\
\hline & - Birlikte karar alma & 43 & 80 \\
\hline & 3. Rol kişisiyle özdeșim kurma (canlandırdığı farklı kişiliklerin yaşadığı duygular) & 34 & 63 \\
\hline
\end{tabular}

Tablo 6'da görüldüğü gibi uygulama öncesindeki katılımcılar sosyal özellikleri konusunda herhangi bir görüş belirtmemişlerdir. Uygulama sonrasında ise öğrencilerin \% 96'sı farklı insanlar (duygular, özellikler vb.) tanıdıklarını ve farklılıkları gördüklerini belirtmektedirler. $\mathrm{Bu}$ temanın etkileşim alt boyutunda ise öğrencilerin \% 96'sı samimiyet kazandıklarını; \% 93'ü kaynaşma, yakınlaşma, yardımlaşma ve dayanışma göstediklerini, sınıftaki gruplaşmaların azaldığını; \%89'u işbirliği ve fikir alışverişi yaptıklarını belirtmişlerdir. Ayrıca bu alt boyutla ilgili olarak katılımcıların \% 87'si kişilere güven duyma davranışı gösterdiklerini; \% 85'i paylaşım ve sosyalleşme yaşadıklarını; \% 80'i ise görev dağılımı ve paylaşımı ile birlikte karar alma süreçlerinde olumlu davranışlar kazandıklarını söylemişlerdir. Bu görüşlerin yanı sıra katılımcıların \% 63 'ü rol kişisiyle özdeşim kurarak canlandırdığı farklı kişiliklerin yaşadığı duyguları yaşadığını dile getirmiştir. 
Uygulama öncesinde katılımcılar sosyal özellikleri konusunda herhangi bir görüş belirtmezlerken, uygulama sonunda öğrenci görüşlerine göre katılımcı grubun oldukça olumlu ve yüksek oranlarda sosyal gelişim özellikleri kazandıkları ortaya çıkmaktadır. Sosyal gelişim konusuda öğrenci görüşlerinden bazıları aşağıda sunulmuştur:

“...sınıf ortamımızla ilgili nefretimizin ortadan kalkmasını sağladı.” (ö9)

“...sınıf olarak bizi yakınlaştırdı, konuşmadığımız, kırgın olduğumuz ya da sevmediğimiz arkadaşlarımızla iletişime girmek durumunda kaldık, önceleri zorunlu gibi görmemeye

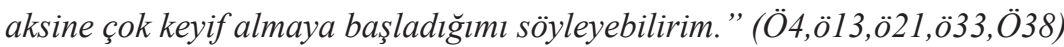

“...bu dersle sinıftakilerle daha fazla haşir neşir olduk herkesi ayrı ayrı dinleyip hep beraber hareket etmeye başladık.” (ö7)

“...farklılıkların, önyarglların, cinsiyetlerin bir kenara bırakılamaması bazen de etnik kökenlerin ve buna bağll olarak siyasi düşüncelerin de etkisiyle bireyler arasında oluşan ve birinci sınıftan itibaren hocalarımızın çabasıyla da her ne kadar aşılmaya çalışılsa da sınıfimız içinde zamanla oluşan ve bir türlü önüne geçilemeyen ikişerli bazen de daha fazla oluşan gruplaşmanın bu dersteki uygulamalar sayesinde 3 sene boyunca birbiriyle selamlaşmanın ilerisine geçmeyen sınıf arkadaşlı̆̆ olarak nitelendirilen ilişkilerimin bir nebze de olsa önüne geçişmiş oldu. ”(ö8,ö12,ö16,ö47)

“...etkinliklerde farklı gruplar belirlendiği için daha önce aynı ortamda bulunmama rağmen hiç konuşmadı̆̆ım arkadaşlarla konuşma-paylaşma-dayanışma ve onlara saygı duyma kavramlarının gelişmesini sağladı.” (ö6,ö12,ö17,ö42)

“...sınıfımız kız-erkek diye ayrılmış durumdayız. Kızlar erkeklerle pek konuşmaz, erkeklerde kızlarla. Hatta sınıfta kızlar ön sıralarda, erkekler arka sıralarda oturur... ama bu ders durumu biraz olsa da yıkmayı başardı bence... bu durum sınıf dışında da etkisini gösterdi, sadece dersle sınırlı kalmadı... keşke böyle bir dersi birinci ya da ikinci sınıfta görmeye başlasaymışız... Belki bir daha geri getiremeyeceğimiz bu güzel yıllarımızı daha güzel birlikte geçirebilirdik." (ö4)

“...bu dersten önce okul hayatımda arkadaşlık ilişkilerimi yok denecek azdl, birinci sınıftan üçüncü sınıfa kadar böyle devam etti. Ama bu drama dersiyle birlikte arkadaşlık ilişkilerimi her geçen hafta gelişti. Önceden sınıf içinde bırakın konuşmayı birbirimize selam dahi vermiyorduk... bu drama dersiyle birlikte ilişkilerimiz her geçen gün arttı sınıf içinde yada dışında birbirimizi gördügümüzde selam veriyor ve hal hatır soruyorduk.” (ö3,ö15,51)

“...kendimize karşı özgüvenimiz, arkadaşlarımıza karşı da güven duygumuzu artırmıştır. Grup etkinliklerinde fikirlerimizi ileri sürerken farkl özelliklere sahip olduğumuzu keşfettik. Bu farklılıklar dâhilinde paylaşmanın ve başarıya ulaşmanın tadını tattık."

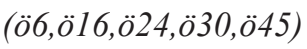

“...bu ders bu teknikle işlenmeseydi mezun olup gittiğimizde ayn ortamda 4 yılı beraber geçirdiğimiz arkadaşlarımızla belki de hiç konuşmamış belki de kırgın olduğum arkadaşlarımla kırgın olarak ayrılmış olacaktım, ama bu ders sayesinde sınıftaki tüm arkadaşlarımla konuşma firsatı buldum. "(ö9)

“...şu an sınıftaki tüm arkadaşlarımla ilgili az çok bir düşüncem var kim neleri sever, ne yapmaktan hoşlanır nasıl bir kişiliğe sahip ...vb.” (ö19)

“...sonuç olarak 3 yıl boyunca hiç diyaloğa geçmemek bize bir şeyler kazandırmamış. Aksine çok şey kaybetmişiz kendimizden... (ö3,14, ö33) 
İnsan İlişkileri ve İletişim Dersinde Yaratıcı Drama Uygulamalarının Etkisine İlişkin Öğrenci Görüşleri

“...üçüncü sınıfta olmamıza rağmen hiç konuşmadı̆̆ımız arkadaşlarımızla konuştuk. ”(ö16)

“...akadaşlarımla ilgili ön yargılarımı bir kenara bırakıp tüm arkadaşlarımla konuşup sohbet ederek grup oyunları oynamama katkı sağladı.” (̈̈9)

“...zayıf olan arkadaşlık ilişkilerimin güçlenmesine ve sınıfta hiçbir iletişim kurmadiğım arkadaşlarımla ders süresi ilerledikçe iletişim kurma imkânı.” (ö9,12,ö15,ö48)

“...arkadaşlarımla ilgili önyargılarımın zaman geçtikçe ortadan kalkmasına yardımcı oldu bunun sonucunda arkadaşlarımla aynı grup içinde yer alıp grup ruhunun geliştiğini fark ettim birlikte hareket ederek birbirimizi dinlemeyi takip etmeyi ve birbirimizle konuşup iletişim kurmayı başardık. ”(ö9,ö11,ö41)

“...Bu dersten önce birbirimize ne kadar soğuk davrandığımızı, bir birimizle mesafeli olduğumuzu aynı sınıfta olmamıza rağmen birbirimizden çok uzak olduğumuzu ve bu dersten sonra her geçen gün ilişkilerimizin güçlendiğini ve yakınlaştığımızı fark ettim."

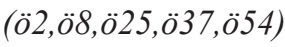

“...Önce sınıfımızda fazlasıyla gruplaşma söz konusuydu. İsmini dahi bilmediğim ya da fark etmediğim, görmediğim kişiler vardl. Hiçbir şekilde kendi arkadaş grubumuz dişında kimseyle diyaloğa geçmezdik. Diyaloğa geçmek bir yana yüzümüze bakmazdık. Bu şekilde olduğu takdirde de bir özgüvensizlik çekinme ve önyargılar meydana geliyordu. Birçok arkadaşımızla hiç konuşmamış olsak bile onun hakkında fikir sahibi olduğumuzu düşünüyorduk. " (ö10,ö13, $\ddot{o} 23, \ddot{o} 39, \ddot{o} 51)$

“...arkadaşlık ilişkilerimizde büyük katkı sağladı ve birbirimizi tanıma, sohbet etme imkanı

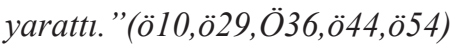

“...canlandırdı̆̆ım karakterdeki kişilerin yaşadığ o anki duyguları (sevinç, üzüntü, sinirlenme, endişelenme) yaşadım bu duygu durumlarında sakinliğimi ve durgunluğumu koruyamadı̆̆ımı gördüm.” (ö2,ö15,53)

“...ilk kez yüz yüze bakıyorduk sınıfımızdaki kutuplaşmalar dağıldı, birbirimize karşı ördüğ̈̈müz duvarlar aralandl. ”(ö14)

“...grup oyunlarımızda bir liderin düşüncelerine bağlı kalmadık, kendi düşüncelerimizi ortaya koyduk, kabul görmese bile grubun fikrine uymayı, ortak karar almayı ögrendik." (ö14,ö27)

“...sadece not dışında, ders dışında bir diyaloğumuzun olabileceğini ve bunu aslında mümkün olabileceğini düşünüyorum not dışında başka bir dili konuşabileceğimiz bir ortamın olduğunu gördüm (ö4)

“...arkadaşlık ilişkilerimiz olumlu yönde etkilenmiştir. Çünkü drama sayesinde sınıf ortamından uzaklaşıp daha samimi bir ortama girme firsatı bulduk ve bu ortamda birbirimizle hep diyalog halinde olduk, sınıfta bir sıra arkamızdan haberimiz olmazken bu yöntemde hep iç içe olduk." (ö15) 
Tablo 7. Öğrencilerin Uygulama Öncesinde ve Uygulama Sonrasındaki Duygu Özelliklerinin Karşılaşıtırılması

\begin{tabular}{lcclcc}
\hline Uygulama Öncesi Temalar & f & $\mathbf{\%}$ & Uygulama Sonrası Temalar & f & \% \\
\hline Duygular & & & Duygular teması & & \\
Derslerin sıkıcılığı & 40 & 74 & Eğlenme & 52 & 96 \\
Soğukluk (sınıf ortamı) & 32 & 60 & Derse katılımda isteklilik & 50 & 93 \\
Nefret (sınıf ortamı) & 28 & 52 & Komik, güldürücü & 48 & 89 \\
& & & Mutlu olma (mutluluk) & 47 & 87 \\
& & & Rahat hissetme & 43 & 80 \\
& & & Rahatlama (psikolojik ve bedensel) & 38 & 70 \\
& & & Fiziksel temas & 15 & 27 \\
\hline
\end{tabular}

Tablo 7'de görüldüğü gibi katılmc1 grubun \% 74'ü derslerin sıkıc1lı̆̆ından; \% 60’1 sınıf ortamındaki ilişkilerin soğukluğundan; \% 52'si ise kendi sınıfına karşı hissettiği nefret duygusundan söz etmiştir. Uygulama sonrasında ise öğrencilerin \% 96's1 eğlendiklerini, \% 93'ü bu dersin etkinliklerine katılmada istekli olduklarını, \% 89'u uygulamaları güldürücü bulduklarını, \% 87'si mutluluk duydukların belirtirken, \% 80'i kendilerini rahat hissettiklerini ve psikolojik ve bedensel rahatlama yaşadıklarını, \% 27'si arkadaşlarıyla fiziksel temasta bulunabilmenin yarattığı duyguyu hissettiklerini dile getirmişlerdir.

Diğer temalarda olduğu gibi duygular temasında da uygulamadan önce grubun büyük çoğunluğu olumsuz üç duygudan söz ederken; uygulama sonrasında büyük oranda olumlu ve çeşitli duygular yaşadıkları gözlenmiştir. Duygular temasıyla ilgili olarak öğrenci görüşlerinden bazıları şunlardır:

“...ve gerçekten gülebildiğimi mutlu olduğumu, bir şeyler yapabildiğimi gördüm.” (ö12)

“... güldürücü bir ortam yaratıp rahatlamamızl sağllyor.” (ö3, ö8, ö14,ö19,ö21,ö34,ö44,ö53)

“...kurallar ve sinıf yok, ögrencinin rahat olması ön planda, koş zipla, gül eğlen ... yapılan etkinliklerde her şey bana ve benim özgür iradem bağll olduğu için istediğimi söyleyip istediğim davranışl sergiliyorum, yani doğal oluyorum. "(ö8,22,ö33,ö49)

“...dersteilkzamanlarçekinipsikılırken,şimdikoşakoşagidiyorum.”(ö8,ö12,ö17,ö35,ö46,ö54)

“...çekindin utandım, drama yapamam diye korktum.” (ö12,ö27,ö33,ö48)

“...bu derste normalde yapamayacağımız şeyler, hareketler yapmak durumunda kaldık... ilk derslerde bunun yabancıliğını ve zorluğunu çektim, fakat ögretmenin yarattı̆̆ atmosfer ögretmenin ögrrencilerle diyaloğunun ne kadar önemli bir faktör olduğunu gösterdi. Çünkü karşımda yaptı̆̆ım hareketlere kızan beni kısttlayan ya da beni notla tehdit eden bir hoca ya da durum yoktu, bu durum beni ve ya da öğrencileri biraz daha rahatlatan bir durumdur."(ö4)

“...ögretmenimiz bize komut vermek yerine bizimle birlikte oyunlara katılmış, bize öğretmeye çalıştıklarına kendini de dâhil etmiştir. Bu şekilde bizimle birlikte etkinliklere katılması yol göstermesi içtenlikle olaylara katılması bizi motive etmiştir."(ö15)

“...derse ilk girdiğimiz gün çok fazla çekingen tavırlar sergiliyorduk, herkes kendi arkadaş gruplarıyla bir arada olmak, aynı gruba düşmek için uğraş veriyordu sınıftaki gruplama ilk 
İnsan İlişkileri ve İletişim Dersinde Yaratıcı Drama Uygulamalarının Etkisine İlişkin Öğrenci Görüşleri

gün fazlasıyla hissedilmişti. Daha tanışma ekinlikleriyle 3 yıldır aynı sınıfta olmama rağmen tek bir kelime konuşmadığımı hatta yüzünü bilmediğim kişiler olduğunu fark ettim.” (ö14)

“...fiziksel temasta bulunduk.”(ö6,ö18,ö39,ö46,ö51)

...bu derste en çok hoşuma giden durum bütün ağırlıklarımızı, yüklerimizi yani ayakkabı, çanta, telefon gibi yüklerimizi bırakmak beni çok rahatlattı." (ö4)

\section{Sonuç ve Öneriler}

İnsan ilişkileri ve iletişim dersinde yaratıcı drama uygulamalarının etkisine ilişkin öğrenci görüşlerinin araştırıldığı bu çalışmanın uygulama öncesi ve sonrasında elde edilen verilerinin analizi sonucunda "öğrenme, mesleki gelişim, değerler, kişisel gelişim, sosyal ilişkiler ve duygular" olmak üzere altı tema ortaya çıkmıştır.

Çalışma sonunda "öğrenme temasında" öğrencilerin iletişim konusunda farkındalık kazandıkları, iletişim araç ve yollarını, iletişim ve ilişkileri güçlendirmede neler yapılması gerektiğini, iletişim çatışmalarını nasıl çözecekleri, iletişim engellerini nasıl ortadan kaldıracakları, iletişimde beden dilinin önemi ve teknolojinin kötü kullanımı gibi ders konularını daha etkili ve kolay öğrendikleri belirlenmiştir. Elde edilen bu sonuçlar yaratcı drama uygulamalarının başkalarını dinlemeyi (Öztürk, 2001), yazılı ve sözlü iletişim ve dil becerilerini (Gönen ve Dalkılıç, 2000; Hendy ve Toon, 2001; Akoğuz 2002; Er, 2003; Rances, 2005; Fenli, Acar ve Sahin, 2009; Gökçearslan Çiftçi ve Altınova, 2017), göz teması kurmayı (Öztürk, 2001), beden dili kullanımını (Almaz, İşeri ve Ünal, 2014) olumlu yönde etkilediğinin belirlendiği araştırma sonuçlarıyla da örtüşmektedir. Ancak iletişim araç ve yolları, iletişim ve ilişkileri güçlendirmede neler yapılması gerektiği, iletişim çatışmalarının nasıl çözüleceği, iletişim engellerinin nasıl ortadan kaldırılacağı, iletişim süreçlerinde teknolojinin kötü kullanımı gibi iletişim dersinin kendine özgü içeriği ile ilgili kazanımlara ilişkin alanyazında incelenmiş çalışmalarda olumlu ya da olumsuz ilişkiden bahsedilebilecek sonuçlara ulaşılamamıştır.

Mesleki gelişim temasında ise yapılan etkinliklerin öğrencilere öğretmenlik mesleğini sevdirdiği, öğretmen adaylarına mesleki yaşamlarında nasıl öğretecekleri, öğretirken hangi yöntem- teknikleri nasıl kullanacakları, öğretim sürecininin aşamalarını dikkate alarak süreci nasıl düzenleyecekleri, öğretimde çeşitlilik sağlama ve materyal kullanımı, öğrenci ile bu süreçte nasıl etkili iletişim kuracakları gibi konularda katkı sağladığı belirlenmiştir. Bu tema ile ilgili olarak yaratıcı dramanın yaparak-yaşayarak öğrenmeyi sağlama (Aytaş, 2013) özelliği dışında alanyazında ilgili araştırmalara rastlanmamıştır.

$\mathrm{Bu}$ çalışmalar aracılığıyla kişisel gelişimle ilgili olarak; öğrencilerin özgüven ve cesaret kazandıkları; çekinkenlikten kurtularak sosyal girişimciliklerinin arttığı, kendini tanıma ve ifade etme, düşünme, fikir üretme, empati kurma, yaratıcı ve özgün düşünme, hayal kurma, karar verme, sorun çözme becerilerinin; araştırma, bulma ve anlatma yeteneklerinin geliştiği gözlenmiştir. Araştırmanın kişisel gelişim teması ile ilgili bulguları empati kurmayı (Demircioğlu, 2010), problem çözme becerilerini (Özdemir ve Çakmak, 2008; Çakmakçı ve Özabac1, 2014; Palavan, 2017 ), hayal kurma (Gündoğan, Arı ve Gönen, 2014), hislerini ve düşüncelerini geliştirme (Başçı ve Gündoğdu, 2011; McCaslin, 1990; Ceylan, 2013; Genç, 2003), karar verme becerilerini karar verme mekânizmasını (Tate, 2005; Ceylan, 2013), yaratıcılık yeteneklerini geliştirdiği (Yaffe, 1989; Nickerson, 2009), kendine güven duyma, özgüven ve öz yeterliliği (Morris, 2001; Ceylan, 2013; Tanrıseven ve Aykaç, 
2013), öz disiplini (Köksal Akyol, 2003), öz eleştiriyi (Akpınar Dellal ve Kara, 2010), kendini anlamayı (Köksal Akyol, 2003), kendini gerçekleştirmeyi (Özdemir ve Çakmak, 2008), çok boyutlu düşünmeyi (Akpınar Dellal ve Kara, 2010), eleştirel düşünmeyi (Yaffe, 1989; Yeğen, 2003; Arıkız, ve Beştepe, 2016) kazandırdığını ve geliştirdiğini vurgulayan araştıma sonuçları ile örtüşmektedir. Ancak bu çalışmada elde edilen "anlık cevap ve tepki (hazırcevaplılık)" bulgusu doğrudan kişilerin farklı olay ve durumlarla ilgili deneyim kazanma (McCaslin, 1990; Başçı ve Gündoğdu, 2011; Ceylan, 2013) birebir desteklemese de yakın ilişkili olarak düşünülebilir. Önceki çalışmalarda elde edilen bulgulardan farklı olarak "doğal davranma; sabır ve tahammül gösterme; bedensel gelişim ve aktiflik sağlama” sonuçlarına ulaşılmışır.

Değerler temasında da öğrencilerin eskisine göre birbirlerine daha çok saygı duydukları, daha demokratik davrandıkları, birbirlerine hoşgörü ve anlayış gösterdikleri, önyargısız davranmaya çalıştıkları insanları anlamak için çaba göstediklerini, bireysel ve kültürel farklılıklara saygı duydukları; gönüllülük ve paylaşma, saygı duyma gibi davranış ve değerleri belirttikleri gözlenmiştir. Çalışma sonunda ulaşılan bu sonuçlar; dramanın demokrasi fikrini (Aykaç ve Çetinkaya, 2013), hoşgörülü olmayı (Tanrıseven ve Aykaç, 2013), başkalarına saygı duymayı (Genç, 2003), kişilerin sorumluluk ve risk almayı (Köksal Akyol, 2003; Almaz ve diğerleri, 2014) olumlu yönde etkilediğini vurgulayan çalışmaların sonuçları ile benzerlik göstermektedir.

Yaratıcı drama etkinliklerinin öğrencilerin işbirliği, fikir alışverişi, paylaşma, yardımlaşma kaynaşma, yakınlaşma gibi sosyal özelliklerini geliştirdiği; öğrencilerin farklı insanlar (duygular, özellikler vb.) tanıdıklarını ve onların farklı1ıkları gördüklerini, samimiyet kazandıklarını; kişilere güven duyma davranışı gösterdiğini; paylaşım ve sosyalleşme yaşadıklarını; görev dağılımı ve paylaşımı ile birlikte karar alma süreçlerinde olumlu davranışlar kazandıkları ve bu etkinliklerin sınıf içi gruplaşmaları azalttığı gözlenmiştir. Bu sonuçlar drama ile ilgili yapılan çalışmalarda ortaya çıkan bireyin grubun parçası olması (Başçı ve Gündoğdu, 2011), sosyal etkileşimi artırması (Yassa 1997; Aykaç ve Çetinkaya, 2013), işbirliği ve birlikte çalışma yeteneği kazandırması (Abu Rass, 2010; Adıgüzel, 2013; Ceylan, 2013), bireyin sosyalleşmesini sağlaması (Aykaç ve Çetinkaya, 2013) ve sosyal becerileri kazandırması (Colston 1985; Önalan Akfırat, 2006; Kara ve Çam, 2007; Akpınar Dellal ve Kara, 2010; Namdar ve Çamadan, 2016)'1n bulgularıyla büyük ölçüde desteklenmektedir. Ayrıca bu çalışmada ortaya çıkan "rol kişisiyle özdeşim kurarak canlandırdığı farklı kişiliklerin yaşadığı duygularını yaşama" ulaşılabilen araştırmaların bulgularında gözlenememiştir.

Yine öğrencilerin öğretme-öğrenme sürecinde mutlu oldukları, eğlendikleri, derse katılmada istekli oldukları, kendilerini rahat hissetiklerini ve psikolojik ve bedensel rahatlama yaşadıkları; arkadaşlarıyla fiziksel temasta bulunabilmenin yarattığı duyguyu hissetikleri sonucu ortaya çıkmıştır. Yaratcı dramanın kişilere eğlenceli bir ortam yaratması, kişilerin bu ortamlarda kendilerini rahat hissetmesi, katılımı, istekliliği artırması bulguları alanyazında birçok çalışma tarafından vurgulanmıştır. Ancak bu çalışmanın sonunda katılımcıların "arkadaşlarıyla fiziksel temasta bulunabilmenin yarattığı duyguyu hissetme" sonucu farklı bir bulgu olarak ortaya çıkmış olup alanyazında gözlenememiştir. 


\section{Öneriler}

$\mathrm{Bu}$ çalışma ile ulaşılan sonuçlar doğrultsunda aşağıdaki önerilerde bulunulabilir:

- Drama dersi ve uygulamaları özellikle eğitim fakülteleri başta olmak üzere seçmeli dersler, çeşitli kurslar, öğrenci kulüp ve topluluklarının etkinlikleri vb. yoluyla öğretmen adayının kişisel gelişimi için kullanılabilir.

- Eğitim fakültesi ile birlikte yükseköğretimin tüm kurumlarındaki bireyler bütüncül gelişimleri için hem ders hem de öğretim yöntemi olarak yaratıcı dramadan yararlanmaya (akademik idari ve mali tedbirlerle) teşvik edilebilir.

- Özellikle öğretmen adaylarının mesleki, kişisel, sosyal, duygusal ve değer gelişimleri üzerindeki olumlu etkisi göz önüne alındığında, daha verimli olması açısından yaratıcı drama dersini verecek ya da bir yöntem olarak yaratıcı dramadan yararlanacak öğretim elemanlarının deneyimli olması daha nesnel sonuçlar ortaya koyabilir.

- Yükseköğretim birimlerinde ve özellikle eğitim fakültelerinde drama uygulamaları için uygun fiziki ortamlar oluşturulmalı ve düzenlenmelidir.

- Nitel araştırma yönteminin kullanıldığı bu çalışma kontrol gruplu nicel yöntemlerle farklı gruplarda belli sürelerde denenerek etki boyutunda çalışmalar yapılabilir. 


\section{Kaynakça}

Abu Rass, R. (2010). Drama in chalk and talk classrooms. Journal of Language Teaching and Research, 1(4), 378-381.

Adıgüzel, H. Ö. (2000). Eğitim bilimlerinde (Güzel sanatlar Eğitiminde) bir uzmanlık alanı olarak kültür pedagojisi. (Yayınlanmamış Doktora Tezi). Ankara Üniversitesi, Ankara

Adıgüzel, Ö. (2013). Eğitimde yaratıcı drama. (4 Baskı). Ankara: Pegem-A Yayıncılık.

Akoğuz, M. (2002). İletişsim becerilerinin geliş̧tirilmesinde yaratıcı dramanın etkisi. (Yayınlanmamış Yüksek Lisans Tezi). Ankara Üniversitesi, Ankara.

Akpınar Dellal, N. ve Kara, Z. (2010). Awareness levels of foreign language teacher candidates and teachers about drama techniques. Dil Dergisi, 149, 7-29.

Almaz, G., İşeri, K., ve Ünal, E. (2014). Research of the self-efficacy perceptions of teacher candidates towards the usage of creative drama method. International Journal of Languages' Education and Teaching, 2(3), 48-65.

Andersen, C. (2000), Process drama and classroom inquiry. Üçüncü Uluslararası Drama Eğitimi Araştırmaları Enstitüsü Sempozyumunda sunulmuş bildiri 21-25 Temmuz, Columbus, $\mathrm{OH}$

Annarella, L. A. (1992). Creative drama in the classroom. Washington D.C.: Office of Educational Research and Improvement

Arıkız, S., Beştepe, N . (2016). Tasarım sürecinde yaratıcılık "teknoloji ve tasarım dersinin yaratıcı drama yöntemiyle işlenmesi. Yaratıcı Drama Dergisi, 11(2), 47-64. DOI: 10.21612/yader.2016.011

Aya, Y , Günay, R , Aydın, H . (2016). Okul öncesi eğitimde drama yöntemi ile işlenen değerler eğitimi derslerinin farkındalık düzeyi üzerindeki etkisi. Sakarya University Journal of Education, 6(1), 23-37. DOI: http://dx.doi.org/10.19126/suje.76036

Aykaç, M. ve Çetinkaya, G. (2013). The effect of creative drama activities on pre-service Turkish language teachers' speaking skills. Turkish Studies- International Periodical for the Languages, Literature, and History of Turkish or Turkic, 8(9), 671-682. Doi :10.7827/TurkishStudies.5503

Aytaş, G. (2013). Eğitim ve öğretimde alternatif bir yöntem: Yaratıcı drama. Adiyaman Üniversitesi Sosyal Bilimler Enstitüsü Dergisi, 6(12), 35-54.

Başç, Z. ve Gündoğdu, K. (2011). The attitudes and opinions of prospective teachers related to dramacourses: The case of Atatürk University. Elementary Education Online, 10(2), 454-467.

Bütün, M., Tüzüner, A. , ve Duman, N . (2015). Coğrafya öğretmen adaylarının yaratıcı drama yöntemine ilişkin görüşleri. Yaratıcı Drama Dergisi, 10 (1), 1-14. DOI: 10.21612/yader.2015.001

Büyüköztürk, Ş., Kılıç-Çakmak, E., Akgün, Ö.E., Karadeniz, Ş. ve Demirel, F. (2010). Bilimsel Araştırma Yöntemleri, (6.Bask1). Ankara: Pegem Akademi Yayıncılık.

Ceylan, Ş. Y. (2013). Dramatik etkinlikler ve dramanın çocuğun gelişimindeki yeri. E. Ömeroğlu (Ed.), Okul öncesi eğitimde dramatik etkinliklerden dramaya teoriden uygulamaya (s. 17-43) içinde. Ankara: Eğiten Kitap Yayınc1lık

Colston, GL. (1985). The effects of a creative drama workshop and an arts on film program on the social interaction of deinstitutionalized developmentally disabledpersons (Therapeutic recreation, District of Columbia). PhD. Usa: University of Maryland Press.

Çakmakçı, E., ve Özabacı, N . (2014). Drama yolu ile karar verme becerilerinin kazandırılması. Elektronik Sosyal Bilimler Dergisi, 12 (44), 18-30.

Demir, K. (2012). "Sinıf ögretmeni adaylarına kırsal kesim sosyal yaşam becerilerini kazandırmada yaratıcı dramanın etkisi” Milli Eğitim Bakanlığı Özel Doğaç Yaratıcı Drama Eğitmenliği/Liderliği Bitirme Projesi. Ankara.

Demircioğlu, Ş. (2010). Teaching english vocabulary to young learners via drama. Procedia Social and Behavioral Sciences, 2(2), 439-443. https://doi.org/10.1016/j.sbspro.2010.03.039 
İnsan İlişkileri ve İletişim Dersinde Yaratıcı Drama Uygulamalarının Etkisine İlişkin Öğrenci Görüşleri

Dikici, H., Koç, M. ve Gündoğdu, R., (2003, Temmuz). Yaratıcı dramanın problem çözme becerilerine etkisi. (ÖZ).VII. Ulusal Psikolojik Danışma ve Rehberlik Kongresinde sunulan bildiri ( s. 107) içinde. Malatya. Erişim: https://issuu.com/antalyaozelegitimgrubu/docs/vii_ulusal_ps_koloj_k_dani_ma_re

Er, A. (2003). Drama ve dil öğretimi: Dramanın sözlü dil öğretimine etkisi. Kazım Karabekir Eğitim Fakültesi Dergisi, 8, 246-254

Ergin, A. ve Birol, C. (2000). Eğitimde Iletişim. Ankara: Anı Yayıcılık.

Fenli, A., Acar, V. ve Şahin, H. (2009, Ekim). Drama dersinin iletişim becerilerine katkısı (ÖZ). 18. Ulusal Eğitim Bilimleri Kongresinde sunulan sözlü bildiri. Ege Üniversitesi, İzmir. https://www.pegem.net/Akademi/bildiri_detay.aspx?id=101283

Genç, N. H. (2003). Yabancı dil öğretiminde öğretim tekniği olarak dramanın kullanımı ve bir örnek. Kazım Karabekir Eğitim Fakültesi Dergisi, 8, 267-276.

Gökçearslan Çifçi, E , Altınova, H .H. (2017). Sosyal hizmet eğitiminde yaratıcı drama yöntemiyle iletişim becerisi geliştirme: ders uygulaması örneği. Illkögrretim Online, 16 (4), 1384-1394. DOI: 10.17051/ilkonline.2017.342961

Gönen, M. ve Dalkılıç, N. (2000). Çocuk eğitiminde drama: Yöntem ve uygulamalar. İstanbul: Epsilon.

Gündoğan, A., Arı, M. ve Gönen, M. (2014). The Effect of Drama on the Creative Imagination of Children in Different Age Groups. Hacettepe Üniversitesi Eğitim Fakültesi Dergisi, 28(28-2), 206-220.

Hendy., L., Toon, L. (2001). Supporting drama and imaginative play in the early years. Open University Press, Hurd, B. M. (1991). Teach by the light of the moon, Science and Education. 31(2), 23-24

Kara, Y. ve Çam, F . (2007). Yaratıcı drama yönteminin bazı sosyal becerilerin kazandırılmasına etkisi. Hacettepe Üniversitesi Ĕgitim Fakültesi Dergisi, 32, 145-155.

Karasar, N. (2003). Bilimsel araştırma yöntemleri, (12.Baskı). Ankara: Nobel Yayıncılık.

Köksal Akyol, A. (2003). Drama ve dramanın önemi. Türk Eğitim Bilimleri Dergisi, 1(2), 179-190.

McCaslin, N. (1990). Creative drama in the classroom (5. Bask1.). Londra: Longman.

Merriam, S.B. (2013). Nitel Araştırma Desen ve Uygulama İçin Bir Rehber, (Çev.Editörü: Selahattin Turan). Ankara: Nobel Yayınları.

Metin G. G. (1999). Dramanın 5-6 yaş çocuklarının sosyal duygusal gelişimlerine etkisinin incelenmesi. M. $\ddot{U}$. Eğitim Bilimleri Enstitüsü. Istanbul

Morris, R. V. (2001). Drama and authentic assessment in a social studies classroom. Social Studies, 92 (1), 41-45.

Namdar, A. O. ve Çamadan, F. (2016). Yaratıcı drama uygulamalarının öğretmen adaylarınınsosyal becerilerine etkisi. Gazi Üniversitesi Ë̆itim Fakültesi Dergisi.36(3), 557-575

Nickerson, L. (2009). Science drama. School Science Review, 90 (332), 83-89.

Oğuz, A. ve Altun, E. (2011, Nisan) Öğretmen adaylarının yaratıcı dramaya yönelik tutumları ile empatik eğilim düzeyleri arasındaki ilişkinin incelenmesi. 2nd International Conference on New Trends in Education and Their Implications (s.1545-1552) içinde. Antalya. Erişim: http://iconte.org/FileUpload/ks59689/ File/269.pdf

Okvuran, A. (2000). Yaratıcı dramaya yönelik tutumlar. (Yayınlanmamış Doktora Tezi). Ankara Üniversitesi Sosyal Bilimler Enstitüsü, Ankara.

Önalan Akfirat, F . (2006). Sosyal yeterlilik, sosyal beceri ve yaratıcı drama. Yaratıcı Drama Dergisi, 1(1), 39-58

Özdemir, S. M. ve Çakmak, A. (2008). The effect of drama education on the prospective teachers' creativity. International Journal of Instruction, 1(1), 13-30.

Özşenler, D. (2013) Grup içi iletişimin etkinliğinde yaratıcı drama kullanımı ve kendini açma becerisi. (Yayımlanmamış Yüksek Lisans Tezi). Ege Üniversitesi Sosyal Bilimler Enstitüsü, İzmir 
Öztürk, A. (2001). Eğitim-öğretimde yeni bir yaklaşım: Yaratıcı drama. Kurgu Dergisi, 18, 251-259. Erişîm: http://hdl.handle.net/11421/1424

Palavan, Ö . (2017). Impact of drama education on the self-confidence and problem-solving skills of students of primary school education. Kastamonu Ĕ̈itim Dergisi, 25(1), 187-202.

Rances, J. N. (2005). Student perceptions of improving comprehension through drama as compared topeotry andfiction in college english freshman composition courses. (Yayınlanmamış Doktora Tezi). Widener University, Chester, $P A$

Rusilowski, J. A. (2017) Drama for developing integrity in Higher Education. Erişim: https://www.nature.com/ articles/palcomms201729 doi:10.1057/palcomms.2017.29

San, İ. (1990). Eğitimde yaratıı drama. Ankara Üniversitesi Eğitim Bilimleri Fakültesi Dergisi. 23(2), 573582.

San, İ. (2006). "Eğitimde yaratıcı drama" yaratıcı drama 1985-1998 yazılar. (Ed. H. Ömer Adıgüzel). Ankara: Naturel Yayınları.

Selimhocaoğlu, A. (2004, Temmuz). Drama ve ilkögretimde dramanın önemi (ÖZ). XIII. Ulusal Eğitim Bilimleri Kurultayında sunulan bildiri, Malatya ) Erişim: https://www.pegem.net/ Akademi/ bildiri_detay. aspx?id $=7843$

Tanrıseven, I. ve Aykaç, M. (2013). Opinions of the university students related to creative drama's contribution to their personal and professional lives. Adlyaman Üniversitesi Sosyal Bilimler Enstitüsü Dergisi, 6(12), 329-348.

Taşar, T. (2012) "Empati kurma becerisinin iletişime katkısının yaratıcı drama yöntemiyle işlenmesi" Milli Eğitim Bakanlığı Özel Doğaç Yaratıcı Drama Eğitmenliği / Liderliği Bitirme Projesi. Ankara.

Tate, K. J. (2005). A conceptual lens for observing, analyzing, and interpreting data when exploring preservice creative drama. Youth Theatre Journal, 19(1), 151-170.

Turner, H., Mayall, B., Dickinson, R., Clark, A., Hood, S., Samuels, J., ve Wiggings, M. (2004). Children engaging with drama: An evaluation of the National Theatre 's drama work in primary schools. London: Institute of Education, University of London.

Üstündağ, T. (1994). Günümüz eğitiminde dramanın yeri, Yassadkkça Eğitim Dergisis, 37,7-10

Üstündağ, T.(2006). Yaratıcı drama öğretmeninin günlüğ̈̈̈, Ankara: Pegem-A yayıncılık

Winston, J. (2002). Drama, spirituality and the curriculum. International Journal of Children's Spirituality, 7 (3), 241-255.

Yaffe, S. (1989). Drama as a teaching tool. Educational leadership, 46(6), 2935.

Yalın, H. İ. (2000). Öğretim teknolojileri ve materyal geliştirme. Ankara: Nobel Yayın Dağııım.

Yassa, N. A. (1997). A study of the effect of drama education on social interaction in high school students. Lakehead University, Ontario, Canada: Thunder Bay.

Yazar, A., Çelik, M., ve Kök, M. (2010). Okul öncesi eğitimde yaratıcı dramanın çocuğun gelişim alanlarına etkisi. Atatürk Üniversitesi Kazım Karabekir Eğitim Fakültesi Dergisi, 16, 15-21.

Yeğen, G. (2003). Yaratıcı drama. İlköğretim-Online Öğretim Uygulamaları Serisi, 2(2), 1-4.

Yılmaz, S. (2015). Sosyal bilgiler öğretiminde bir yöntem olarak dramanın kullanımına ilişkin öğretmen adaylarının görüşleri. Ahi Evran Üniversitesi Kırşehir Eğitim Fakültesi Dergisi, 14 (2), 123-145 


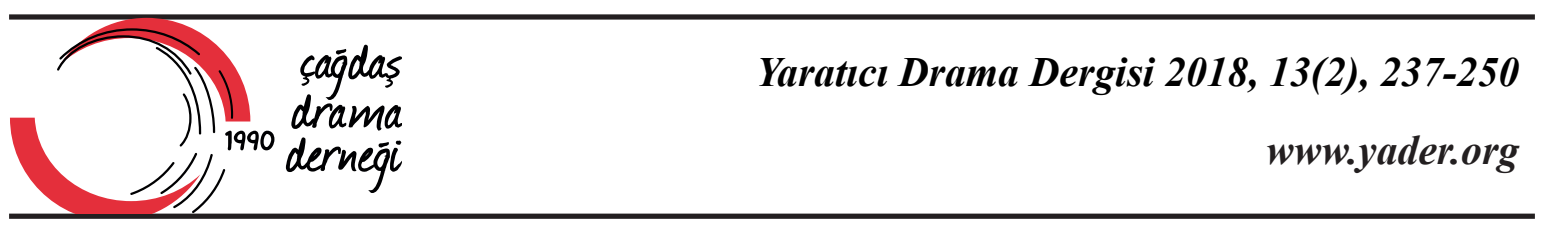

\section{Okul Öncesi Dönemde Yaratıcı Drama Yoluyla Değerler Eğitimi \\ Yıldiz Kaya ${ }^{1}$ \\ Serap Antepli ${ }^{2}$}

\begin{tabular}{|c|c|}
\hline Makale Bilgisi & $\ddot{O} z$ \\
\hline DOI: $10.21612 /$ yader.2018.017 & $\begin{array}{l}\text { Araştırmanın amacı okul öncesi dönem çocukları için hazırlanan "Yaratıcı drama } \\
\text { yoluvla değerler eğitimi" uvgulamalarının etkili olup olmadığın belirlemektir. Bu }\end{array}$ \\
\hline Makale Geçmişi & çalışmada okul öncesi dönemde bulunan çocukların sevgi, saygl, sorumluluk, iş \\
\hline 09.02 .2017 & birliği, paylaşma, temizlik, sabır, güven, dürüstlük, çalışkanlık ve eşitlik değerlerini \\
\hline 17.05.2018 & $\begin{array}{l}\text { fark etmelerine ve dolasıyla değerler eğitimi konusunda farkındalık geliştirmelerine } \\
\text { yaratıcı drama yönteminin etkisi araştırlmıştır. Çalışma, yaşları } 5 \text { ve } 6 \text { arasında } \\
\text { değişen toplam } 16 \text { çocuk ile yürütülmüştür. Çocuklara değerler eğitimi için hazırlanan } \\
\text { yaratıcı drama etkinlikleri } 18 \text { oturumda birer ders saati süresince uygulanmıştır. }\end{array}$ \\
\hline Anahtar Sözcükler & $\begin{array}{l}\text { Çalışmada veri toplama aracı olarak araştırmacı tarafindan hazırlanan "Okul öncesi } \\
\text { dönemde yaratıcı drama yoluyla değerler eğitimi değerlendirme anketi” kullanılmıştır. }\end{array}$ \\
\hline Değerler eğitimi & Çocukların drama uygulaması öncesi ve sonrası değerler eğitimi ölçme aracından almış \\
\hline Okul öncesi & oldukları puanlar arasında anlamlı bir fark gösterip göstermediğine ilişkin sonuçlar \\
\hline Yaratıcı drama & $\begin{array}{l}\text { için Wilcoxon işaretli sıralar testi kullanılmıştır. Analiz sonuçları araştırmaya katılan } \\
\text { çocukların değerler eğitimi ölçme aracından aldıkları deney öncesi ve sonrası puanları } \\
\text { arasında anlamlı bir fark olduğunu göstermektedir }(z=3.41, p<.01) \text {. Fark puanlarının } \\
\text { sıra ortalaması ve toplamları dikkate alındığında, gözlenen bu farkın sontest puanları } \\
\text { lehine olduğu görülmüşür. Bu sonuçlara göre yaratıcı drama yoluyla değerler eğitimi } \\
\text { uygulamalarının çocukların değerler eğitimi puanlarına önemli düzeyde etkisinin } \\
\text { olduğu söylenebilir. Sonuç olarak bulgular, değerler eğitimi kazandırma konusunda } \\
\text { yaratıcı drama yönteminin etkili olduğunu göstermektedir. }\end{array}$ \\
\hline
\end{tabular}

\section{The Values Education In Preschool Period Through} Creative Drama

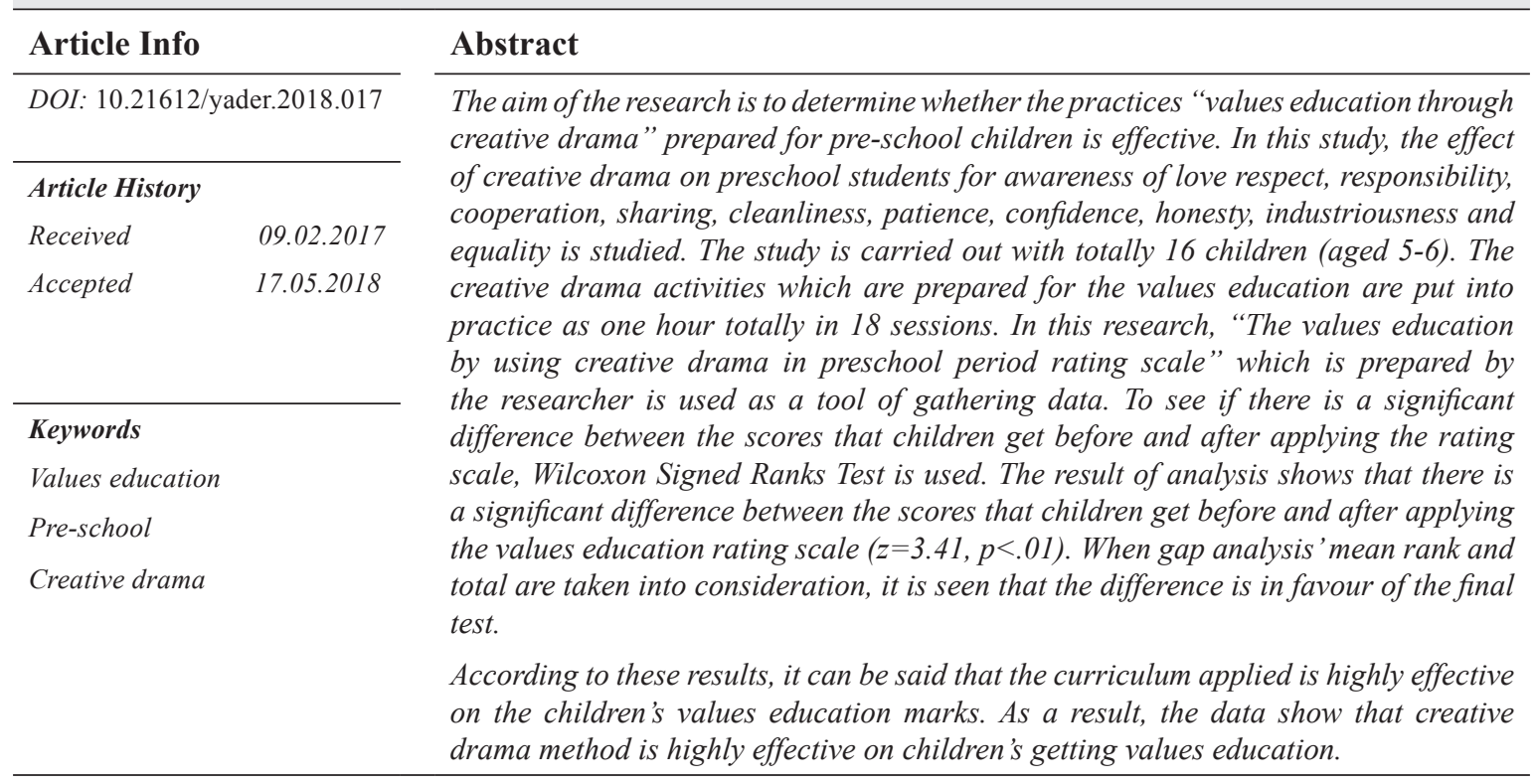

Bil. Uzm., Milli Eğitim Bakanlığı, Şehit Teğmen Ertuğrul Pilatin İlkokulu, Ankara, E-posta: yildiz.ky@gmail.com

2 Çocuk Gelişimi Uzmanı Drama Eğitmeni, Çağdaş Drama Derneği, E-posta: serapmiya@hotmail.com. 


\section{Giriş}

Kişiliğin temelleri çocuklukta atılmakta, ergenlikte oluşmakta, yetişkinlikte yaşanmaktadır (Antepli, 2016). Çocukluk dönemindeki gelişmeler yaşamın ileriki yıllarında kendini göstermektedir. Okul öncesi dönemde verilen eğitimle çocukların bütün gelişim alanları desteklenmektedir. Önemi giderek artan okul öncesi eğitimde yaratıcı drama etkinliklerine yer verilmekte ve yaratıcı dramanın bir yöntem olarak kullanıldığı görülmektedir.

Adıgüzel (2012) dramayı "İçinde eylem olan, bir ya da birden çok insanın birbirleriyle, doğayla ya da başka nesnelerle etkileşerek yaşadıkları içsel ve dışsal devinimler ve onların yaşam durumlarını geniş ölçüde içeren etkinlikler" olarak tanımlamıştır. San (1991) ise yaratıcı dramayı "Bir kavramın, bir ders konusunun, bir metnin daha iyi anlaşılır k1lınması, bireyce ve grupça özümsenip içsel yaşantıya dönüşmesi, gözden geçirilerek, üzerinde düşünülerek dişa vurulmasıdır" şeklinde tanımlamaktadır.

Okul öncesi eğitim kurumları çocuğun ailesinden sonra karşılaştığ i ilk sosyal alandır ve çocuk bu sosyal alanda arkadaşlarıyla birlikte yaşamanın gerektirdiği uygun davranışları burada yaşadığı deneyimler sayesinde öğrenir. Böylece çocuğun sosyal açıdan hayata uyum süreci de başlamış olur. Drama teknik ve yöntemlerinden faydalanılarak sosyal gelişim desteklendiğinde çocukların uygun sosyal davranışları öğrenmeleri ve bunları uygulamaları daha kolay olabilmektedir. Çünkü drama, grupla birlikte olma, iş birliği yapma, paylaşma ve başkalarının haklarına saygı duyma gibi kavramları temel almaktadır (Aslan, 2008).

Yaratıcı drama okul öncesi eğitimde yer alan yöntemlerden biri olarak karşımıza çıkmaktadır. Drama etkinliği tek başına planlanabileceği gibi günlük plan içerisinde yer alan diğer etkinliklerle bütünleştirilerek de planlanıp uygulanabilmektedir. Bulut Pedük ve Erdoğan (2011)'ın belirttiği gibi, çocuklarla birlikte söylenilen bir şarkıdan yola çıkılarak doğaçlamaların, anlatılan öykülerin dramatizasyonun yapılması ya da yeni öykülerin oluşturulup doğaçlamalarının gerçekleştirilmesi şeklinde planlanan öğrenme süreçlerinde drama etkinliği ile müzik ve Türkçe etkinliklerinin bütünleştirilmesi söz konusu olabilmektedir (Köksal Akyol, 2012).

Bireyin hayatında ciddi bir öneme sahip olan okul öncesi dönemde çocukların öğrendiklerini uygulamaya geçirmelerinde yaratıcı drama yönteminin etkisi çok büyüktür (Ulutaş 2011). Yaratıcı drama, erken çocukluk döneminden itibaren, yetişkinlik de dahil olmak üzere bütün yaşam dönemlerinde oyunun gücünü kullanan etkili bir alan olarak karşımıza çıkmaktadır. Özellikle okul öncesi dönemde uygulanan yaratıcı drama etkinliklerinin çocukların bilişsel, dil, sosyal-duygusal ve motor gelişimleri ile öz bakım becerilerini doğrudan desteklediği savunulmaktadır.

Drama çocuğun sosyalleşmesine katkı sağlamaktadır. Çeşitli etkinliklerin özelliğine göre tartışan, konuşan, olayları yaşayan, gözleyen ve yaratan çocuk, sosyal iletişimin temellerini sağlamlaştırır. Çocuk grup içerisinde iş birliğini, paylaşmayı, dayanışmayı, başkalarına saygı duymayı, duyarlı olmayı ve birbirlerini kabul etmeyi öğrenir. Böylece çocuğun hem kendine hem de başkalarına güven duygusu gelişir (Gönen ve Dalkılıç, 2003; Yazar, Çelik ve Kök, 2007).

Farklı yaşantıları tanıma, farklı rollere girerek farklı olay ve durumlarla ilgili deneyim kazanma, yaşamın çok yönlü algılanmasını ve araştırma isteğinin gelişimini sağlama, yaparak, yaşayarak öğrenme ve öğrenilenlerin kalıcı olması drama çalışmaları sonucunda bireylerde olması beklenen kazanımlar arasında sayılabilir. Bu kazanımlar dikkate alındı̆̆ında dramanın bireylerin gelişiminde önemli bir etkisinin olduğu söylenebilir (Köksal Akyol, 2003). 
Yaratıcı drama, çocuklara verilmek istenen birçok konu ve kazanımların hem eğlenceli hem de kalıcı bir şekilde öğrenimini sağlamaktadır. Bu dönemde verilmesi gereken en önemli konulardan biri değerler eğitimidir. Değerler eğitimi bireyin kendine ve topluma yararlı olmasını sağlayacak temel değerleri anlayarak birbiriyle ilişkilendirme ve bireye kazandırma eğitimidir.

Okul öncesi dönem, çocuklarda değerlere ilişkin bilgilerin temellerinin atıldı ̆̆ ilk dönemdir. Değerler temel ögeleri içerir fakat yaşanılan çevre, kültürel özellikler, eğitim ve deneyimler gibi pek çok faktöre göre farklılıklar gösterebilir. Değerlere ilişkin bilgiler tüm hayat boyunca devam eder. Fakat ilk bilgiler erken dönemlerde kazanılmaya başlanır ve kişiliğin oluştuğu dönemlere yani son ergenlik dönemine kadar devam eder. Bu süreden sonra da değerlere ilişkin değişimler elbette mümkündür fakat temel değerler oluşmuştur (Balat Uyanık ve Balaban Dağal, 2009; Balat Uyanık, 2005).

Değerler insanların duygu, düşünce ve davranış boyutlarıyla yakından ilgilidir. Sosyal bilimciler, değerlerin insan davranışlarını açıklamada temel bir öneme sahip olduğunu ifade etmektedir (Dilmaç ve Ekşi, 2007). Değerler, davranışlara rehberlik eden etik kurallar, temel inanışlar, doğru ve yanlışı açıklayan standartlardır (Halstead, 1996; Erdem, 2007). Taşdemir (2009)'e göre değerler toplumun sosyo-kültürel ögelerine anlam veren temel ölçütlerdir. Matthews (2001) da değerleri, davranışların öncülleri ve araçları olarak görmüştür. Buna göre değerlere, en genel anlamda bir davranışın veya düşüncenin kıymeti veya önemi dikkate alınarak yapılan kişisel tercihler veya toplumun bir üyesi olarak bir birey tarafindan benimsenen ve izlenen genel amaçlar olarak bak1labilir (Dede, 2007, s.13).

Değer eğitimi; ahlaki, kültürel, ruhsal, toplumsal ve bireysel alana ilişkin uygun duyarlılık geliştirmeyi ve bunları içselleştirmeyi içerir. Sosyal bir varlık olarak insan, toplum içerisinde yaşamak ve içinde yaşadığı toplumun değerlerini, inançlarını, davranış biçimlerini dikkate almak zorundadır. Toplumlar, değerleri doğrultusunda bazı davranışların sergilenmesini takdirle karşılar. Örneğin; sadakat, sevgi, cesaret, dostluk, temizlik, sayg1, dürüstlük, nezaket ve benzerleri önem verilen toplumsal değerlerdir. Birey, toplum ile insanlığın varlı̆̆ 1 ve gelişmesi değerlere, özellikle ahlaki değerlere ve onların gerçekleşmesine bağlıdır. İnsanın yaşamdaki doğrularını inandığı değerler belirler. Bu değerlerin uğruna, insanlar fedakarlıkta bulunur, mücadele ederler ve hatta bu uğurda ölümü bile göze alırlar. İnsani değerler ya da temel değerler dediğimiz bu vb. değerler, insanın en iyi tarafını ortaya çıkarmayı ve onun kişiliğini bütünüyle geliştirerek, insani mükemmelliğe erişmesini sağlamayı amaçlamaktadır (Aydın, 2010; Tahiroğlu vd. 2010; Bolay 2007; Dökmen, 2005; Özden 2005; Doğan, 1993).

Değerler eğitiminin hedefi, kendini tanımlama, kendini anlama ve kendini tamamlama gibi pratiksel süreçlerden geçirdiği insanın yetilerini en üst düzeye ulaştırarak, "iyi hayat" yaşamasını sağlamaktır (Kale, 2007 s. 319). Aydın (2010)'a göre değerler eğitiminin amacı, çocuğun doğuştan getirdiği en iyi tarafı ortaya çıkarmak; kişiliğinin her yönüyle gelişmesini sağlamak, bireyi ve toplumu kötü ahlaktan korumak ve kurtarmak, bunun yanında iyi ahlakla donatmak ve devamını sağlamaktır. $\mathrm{Bu}$ nedenle, çocuklara ahlaki ve ahlaki olmayan özellikler hakkında doğru bilgiler verilmeli ve onlarda sağlam kanaatler oluşturulmalıdır. Bu şekilde, çocuklar iyi eğilimlerini geliştirmeyi, kötü eğilimlerine teslim olmamayı denerler ve böylece çocukların karakterleri olumlu yönde gelişir.

Genel olarak değerlerde bir yozlaşma süreci yaşandığı kabul edilmektedir. Çocukların küçük yaşlarda sorumlu davranmasını öğrenemeyeceğine ilişkin yaygın görüşler de bulunmaktadır. Oysa 
uygun davranışlar erken yaşlarda öğrenilmezse, çocuklar büyüdükleri zaman problemler daha kötü sonuçlara neden olabilir. Örneğin şiddet ve cinsellik kültürünün öne çıkması, bölgeler arası dengesizlik ve yetersiz beslenme, çevre kirlenmesi, aile kurumunun zayıflaması, alkol ve madde bağımlılığı, cinsel sapmalar, terör ve savaş, yüksek intihar oranları, paraya tapınma gibi göstergeler karşımıza çıkabilmektedir. Değerlerin yozlaştığı ve anlamını daha fazla yitirmeye başladığı günümüzde değer eğitimine daha fazla önem verilmelidir (Kan, 2010; Balat Uyanık ve Balaban Dağal, 2009 s.24; Hökelekli ve Gündüz, 2007 s.373).

Sağl1klı düşünen, hisseden ve davranan bireylerin yetiştirilebilmesi için gerekli ve vazgeçilmez olan değerler eğitiminin okul öncesi dönemde verilmesinin zorunlu hale geldiği görülmektedir. Değerler eğitimi bilgi, duygu ve davranışın bir arada olmasını gerektirir. Bunu uygulayabilmek için ise yaratıcı drama uygun bir yöntemdir. Değerler eğitiminin yaratıcı drama yoluyla verilmesinin okul öncesi dönem çocukları üzerinde daha etkili ve kalıcı olacağı düşünülmektedir. Bu nedenle bu çalışmada okul öncesi dönemde değerler eğitimin, yaratıcı drama yoluyla verilmesi planlanmıştır. Bu çalışmada okul öncesi dönemde bulunan çocuklarının sevgi, saygı, sorumluluk, iş birliği, paylaşma, temizlik, sabır, güven, dürüstlük, çalışkanlık ve eşitlik değerlerini fark etmesi, yaratıcı drama yöntem ve teknikleri kullanılarak değerler eğitimi konusunda farkındalık geliştirmesi amaçlanmıştır. Çalışmanın sonunda çocukların ele alınan her bir değer hakkında giriş niteliğinde bir ön bilgiye sahip olmaları beklenmektedir.

\section{Yöntem}

\section{Araştırma Modeli}

Yaratıcı drama yoluyla değerler eğitimi uygulamalarının okul öncesi dönemdeki çocukların değerler eğitimi kazanımına etkisini incelemek için yarı deneysel model (tek grupta öntest-sontest düzeni) kullanılmıştır. Tek grup öntest-sontest modelinde gelişigüzel seçilmiş bir gruba bağımsız değişken uygulanır. Ancak hem deney öncesi (öntest) hem de deney sonrası (sontest) ölçmeler vardır (Karasar, 2004).

\section{Çalışma Grubu}

Araştırmanın çalışma grubu, Ankara ili Mamak ilçesindeki Şehit Teğmen Ertuğrul Pilatin İlkokulu anasınıfına devam eden 48-66 ay arasında toplam 16 çocuktan (9 kız, 7 erkek) oluşmaktadır. Katılımcıların drama geçmişi bulunmamaktadır. Çalışma grubu araştırmacının kendi öğrencileri olmakla birlikte uygulamalar araştırmacı tarafından yapılmıştır.

\section{Veri Toplama Araçları}

$\mathrm{Bu}$ araştırmada veriler “Okul Öncesi Dönemde Yaratıcı Drama Yoluyla Değerler Eğitimi Değerlendirme Anketi” ile toplanmıştır. Ölçme aracı araştırmacı tarafından geliştirilmiştir. Değerler eğitimi ile ilgili kuramsal bilgilerden yararlanılarak konu ve kazanımlar belirlenmiştir. Konu alarak alınan sekiz değerin (Sevgi-sayg1, sorumluluk, iş birliği-paylaşma, temizlik, sabır, dürüstlük, çalışkanlık, eşitlik) her biri için üçer madde belirlenmiş olup, toplamda 24 maddeden oluşan bir anket hazırlanmıştır. 
Ölçme aracının geçerlik ve güvenirlik çalışmalarını yapabilmek için drama uygulaması yapılan deney grubu dışında 118 çocuğa daha anket uygulanmıştır. Çalışmanın uygulandığı grup da dahil edildiğinde anket rastgele seçilen ilkokulların anasınıflarına ve bağımsız anaokullarına devam eden yaşları 5 ve 6 arasında değişen toplam 134 öğrenciye uygulanmıştır. Uygulama grubunun cinsiyet dağılımları kız $(n=69 \% 51,5)$ ve erkek $(n=65, \% 48,5)$ şeklindedir.

Ölçülen özellik kapsamında en olumlu yanıt üç puan, en olumsuz yanıt bir puan olacak şekilde derecelendirilme yapılmıştır. Ölçme aracından alınabilecek en düşük puan 24, en yüksek puan 72'dir. Ölçme aracının geçerlik ve güvenirliğine ilişkin kanıtlar 134 geçerli veri ile elde edilmiştir. Geçerlik çalışması kapsamında madde analizleri yapılmış ve yapı geçerliğine ilişkin kanıtlar elde edilmiştir. Güvenirliğine ilişkin kanıt elde etmek için ise Cronbach alpha güvenirlik katsayısı hesaplanmıştır.

\section{Geçerlik Çalışmasına İlişskin Bulgular}

Geçerlik çalışması kapsamında madde analizi ve faktör analizi yapılmıştır. Tablo 1.'de anketin 24 maddeyi içeren uygulamasından alınan toplam puanlara ait betimsel istatistikler görülmektedir. Geçerliklere ilişkin kanıtlar elde edilirken ilk olarak madde toplam puan korelasyonları hesaplanmıştır.

Tablo 1. Ölçme Aracından Elde Edilen Toplam Puanlara İlişkin Betimsel İstatistikler

\begin{tabular}{|c|c|c|}
\hline Ortalama & Alınan En Düşük Puan & Alınan En Yüksek Puan \\
\hline 63.58 & 27 & 72 \\
\hline
\end{tabular}

Tablo 1. incelendiğinde ölçme aracından alınan en düşük puan 27 iken, en yüksek puanın 72 olduğu görülmektedir. Ölçme aracından alınan toplam puan ortalaması ise 63.58 'dir.

\section{Madde Toplam Puan Analizine İlişkin Bulgular}

Tablo 2. Madde Toplam Puan Korelasyonlart

\begin{tabular}{|c|c|c|c|c|}
\hline $\begin{array}{c}\text { Madde } \\
\text { No }\end{array}$ & $\begin{array}{c}\text { Madde Silinirse } \\
\text { Aritmetik Ortalama }\end{array}$ & $\begin{array}{c}\text { Madde Silinirse } \\
\text { Anketin Varyans1 }\end{array}$ & $\begin{array}{c}\text { Düzeltilmiş } \\
\text { Madde-Toplam } \\
\text { Korelasyon } \\
\text { Katsay1s1 }\end{array}$ & $\begin{array}{c}\text { Madde Silinirse } \\
\text { Cronbach Alfas1 }\end{array}$ \\
\hline 1 & 60.79 & 79.71 & .54 & .95 \\
\hline 2 & 60.93 & 79.06 & .56 & .95 \\
\hline 3 & 60.81 & 78.68 & .67 & .95 \\
\hline 4 & 60.87 & 77.50 & .74 & .95 \\
\hline 5 & 60.97 & 77.62 & .64 & .95 \\
\hline 6 & 60.90 & 77.30 & .70 & .95 \\
\hline 7 & 60.85 & 77.84 & .74 & .95 \\
\hline 8 & 60.82 & 77.98 & .76 & .95 \\
\hline 9 & 60.88 & 76.55 & .76 & .95 \\
\hline 10 & 60.85 & 77.78 & .72 & .95 \\
\hline 11 & 60.91 & 78.17 & .65 & .95 \\
\hline 12 & 60.94 & 77.65 & .69 & .95 \\
\hline 13 & 61.11 & 78.31 & .55 & .95 \\
\hline 14 & 61.05 & 76.76 & .70 & .95 \\
\hline
\end{tabular}




\begin{tabular}{|l|l|l|l|l|}
\hline 15 & 60.91 & 79.26 & .50 & .95 \\
\hline 16 & 60.99 & 77.20 & .68 & .95 \\
\hline 17 & 60.85 & 77.90 & .71 & .95 \\
\hline 18 & 60.88 & 78.45 & .63 & .95 \\
\hline 19 & 60.76 & 80.21 & .63 & .95 \\
\hline 20 & 61.05 & 78.48 & .55 & .95 \\
\hline 21 & 61.05 & 77.11 & .58 & .95 \\
\hline 22 & 61.02 & 76.40 & .72 & .95 \\
\hline 23 & 60.96 & 78.68 & .58 & .95 \\
\hline 24 & 61.00 & 77.67 & .68 & .95 \\
\hline
\end{tabular}

Ölçme aracının madde toplam puan korelasyonları hesaplanmıştır. Korelasyon analizlerinde maddelerin ölçek toplam puanları ile yüksek korelasyon göstermesi tüm maddelerin aynı boyutta ölçme yaptığının bir göstergesidir (Tezbaşaran, 1996). Yapılan korelasyon analizlerinde madde toplam puan korelasyonlarının .51 ile .76 arasında değiştiği görülmektedir. Maddelerin toplam puan ile korelasyonları incelediğinde tüm maddelerin aynı yapıyı ölçtüğü değerlendirilmektedir.

\section{Açımlayıcı Faktör Analizine İlişskin Bulgular}

Örneklem büyüklüğünün faktör analizi açısından hangi düzeyde yeterli olduğunu belirleyen Keiser-Meier-Olkin değeri .90 olarak hesaplanmıştır ayrıca Bartlett küresellik testi .01 düzeyinde manidar bulunmuştur. Gerçekleştirilen temel bileşenler analizi, özdeğeri 1.00'den büyük olan dört faktör olduğunu göstermiştir. Bu durum, ölçme aracının en fazla dört faktörlü olabileceğinin göstergesidir. Şekil 1.1'de görülen yamaç grafiği dikkate alındığında, yüksek eğimli iniş sayısının bir olarak değerlendirilebileceği görülmektedir.

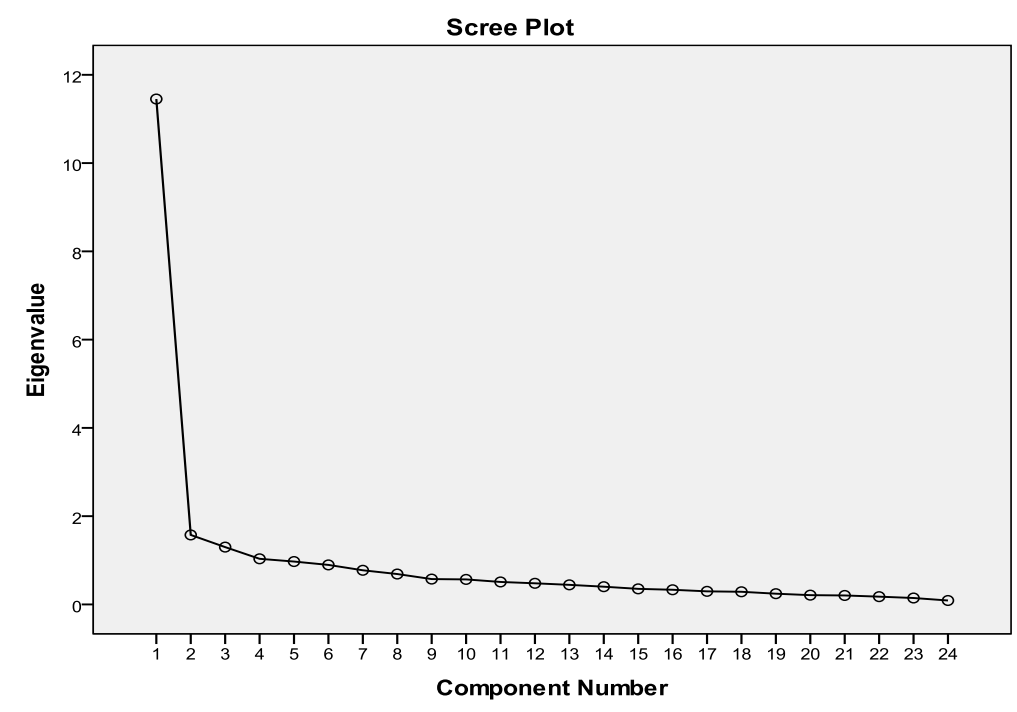

Şekil 1. Açımlayıcı Faktör Analizi Sonucunda Elde Edilen Yamaç (Serpilme) Grafiği

Temel bileşenler analizinden elde edilen verilere göre her bir maddenin tek bir faktör altında .55 ile .80 arasında yüksek faktör yük değerine sahip olduğu görülmektedir ve farklı faktörlerdeki yük değerleri arasında .10'dan daha düşük fark olan maddeler "binişik" olarak kabul edilmiş ve 
farklı faktörlerde binişik olan herhangi bir maddeye rastlanmamıştır. Elde edilen verilere göre ölçme aracının tek faktörlü bir yapıya sahip olduğu görülmektedir. Tek faktörlü yapı toplam varyansın \% 47.72'sini açıklamaktadır. Tablo 3'te ölçme aracında yer alan maddelerin faktör dağılımları ve faktör yük değerleri sunulmuştur.

Tablo 3. Madde Faktör Yük Değerleri

\begin{tabular}{|c|c|c|c|}
\hline Madde No & Faktör 1 & Madde No & Faktör 1 \\
\hline 9 & .80 & 24 & .70 \\
\hline 8 & .79 & 11 & .69 \\
\hline 4 & .77 & 5 & .67 \\
\hline 7 & .77 & 18 & .67 \\
\hline 10 & .76 & 19 & .67 \\
\hline 22 & .75 & 21 & .61 \\
\hline 17 & .74 & 23 & .61 \\
\hline 14 & .73 & 2 & .61 \\
\hline 12 & .73 & 13 & .58 \\
\hline 6 & .72 & 1 & .58 \\
\hline 16 & .72 & 20 & .55 \\
\hline 3 & .71 & 15 & \\
\hline
\end{tabular}

Tablo 3 incelendiğinde tüm maddelerin birinci faktör altında yüksek faktör yük değerlerine sahip olduğu görülmektedir.

\section{Güvenirlik Çalışmaları}

Ölçme aracının güvenirliğine ilişkin kanıtlar için Cronbach alpha iç tutarlılık katsayısı hesaplanmıştır. Ölçme aracından elde edilen güvenirlik katsayısı .95 olarak hesaplanmıştır. Güvenirlik, test puanlarının hatadan arınık olma derecesi olarak tanımlanmaktadır. Cronbach alfa katsayısı hemen hemen tüm ölçme araçlarının güvenirliğini belirlemede kullanılan bir katsayı olarak kabul edilmektedir. Katsayı 1'e yaklaştıkça ölçekte yer alan maddelerin iç tutarlılığının yüksek olduğu sonucuna ulaşı1ır (Kula kartal ve Mor Dirlik, 2016).

\section{Verilerin Toplanması}

Her oturum haftada iki gün 1'er saat (60 dakika) olup, çalışma 24/03/2015 ve 28/05/2015 tarihleri arasında toplam 18 oturum olarak gerçekleştirilmiştir. Uygulamalarda sevgi-sayg1, sorumluluk, iş birliği-paylaşma, temizlik, sabır, dürüstlük, çalışkanlık ve eşitlik değerleri ele alınmış olup her biri için iki oturum düzenlenmiştir. Çalışmanın bütün oturumları yaratıcı drama yöntemi kullanılarak yapılandırılmış ve yaratıcı dramanın rol oynama, doğaçlama, donuk imge, liderin role girmesi teknikleri kullanılmıştır. Uygulama aşamasında oturumların tamamının fotoğrafları çekilmiş, bir kısmı ise kameraya alınmıştır.

\section{Verilerin Analizi}

Veri toplama aracı olarak "Okul Öncesi Dönemde Yaratıcı Drama Yoluyla Değerler Eğitimi Değerlendirme Anketi” kullanılmış olup sonuçlar analiz edilmiştir. Okul Öncesi Dönemde Yaratıcı Drama Yoluyla Değerler Eğitimi Değerlendirme Anketi’nin geçerlik ve güvenirlik çalışması 
yapıldıktan sonra uygulamaya geçilmiştir. Hazırlanan ölçme aracı her çocuk için bir kez uygulama öncesinde, bir kez de uygulama sonrasında sınıf öğretmeni (araştırmacı) tarafından doldurulmuştur. Çocukların drama uygulaması öncesi ve sonrası değerler eğitimi ölçme aracından almış oldukları puanların anlamlı bir farklılık gösterip göstermediğine bakılmıştır.

\section{Bulgular}

Araştırma okul öncesi dönem çocukları için hazırlanan "Yaratıcı drama yoluyla değerler eğitimi” uygulamalarının etkili olup olmadığını belirlemek amacıyla yapılmıştır. Uygulanan drama çalışmalarının öğrenciler üzerindeki etkisi incelenmiştir. Öğrencilerin değerler eğitimi anketinden aldıkları puanların karşılaştırılması için örneklem sayısının 30'un altında olması nedeniyle parametrik olmayan istatistiksel yöntemlerin kullanılması gerekmektedir. Bu nedenle ilişkili ölçümler için Wilcoxon İşaretli Sıralar Testi kullanılmıştır.

Tablo 4. Ön test ve Son test Puanlarına Wilcoxon Işsaretli Stralar Testi Sonuçları

\begin{tabular}{llllll}
\hline Sontest-Öntest & $\mathrm{n}$ & Sira Ortalaması & Sıra Toplamı & $\mathrm{z}$ & $\mathrm{p}$ \\
\hline Negatif Sıra & 0 & .00 & .00 & $3.41^{*}$ & .001 \\
Pozitif Sıra & 15 & 8.00 & 120.00 & & \\
Eşit & 1 & - & - & & \\
\hline
\end{tabular}

*Negatif sıralar temeline dayalı

Çocukların değerler eğitimi yaratıcı drama uygulaması öncesi ve sonrası değerler eğitimi ölçme aracından almış oldukları puanların anlamlı bir farklılık gösterip göstermediğine ilişkin Wilcoxon işaretli sıralar testi sonuçları Tablo 4’te verilmiştir. Buna göre analiz sonuçları, araştırmaya katılan çocukların değerler eğitimi anketinden elde edilen ön test ve son test puanları arasında anlamlı bir fark olduğunu göstermektedir $(\mathrm{z}=3.41, \mathrm{p}<.01)$. Fark puanlarının sira ortalaması ve toplamları dikkate alındığında, gözlenen bu farkın son test puanları lehine olduğu görülmüştür. Bu sonuçlara göre düzenlenen "Yaratıcı drama yoluyla değerler eğitimi" uygulamalarının çocukların değerler eğitimi puanlarına önemli düzeyde etkisinin olduğu söylenebilir.

\section{Tartışma ve Sonuç}

Uygulamalarda sevgi-sayg1, sorumluluk, iş birliği-paylaşma, temizlik, sabır, dürüstlük, çalışkanlık, eşitlik değerleri yaratıcı drama yöntemiyle işlenerek çocukların bu değerlere karşı duyarlılıklarının artırılması beklenmiştir. On sekiz oturum süren uygulama bitiminde çocukların bu konularda farkındalık geliştirdiği ve davranışlarında olumlu değişimlerin olduğu görülmüştür. Yapılan uygulamalar sonrasında çocukların son test puanlarında artış olduğu görülmektedir. Yapılan "Yaratıcı drama yoluyla değerler eğitimi” uygulamalarının okul öncesi dönemdeki çocukların değerler eğitimi kazanımına olumlu etkisinin olduğu görülmüştür. Buna göre çocukların değerlere ilişkin bilgi ve tutumlarının yaratıcı drama yöntemi kullanılarak geliştirilebileceği söylenebilir. Okul öncesi dönemde yaratıcı drama yöntemi diğer yöntemlere göre çok daha etkili olabilmektedir. Çocuklar yaparak ve yaşayarak çok daha kalıcı ve hızlı öğrenmektedirler. Bu sayede çocuklar durumlar arasında sebep sonuç ilişkisi kurmakta ve çocukların yaşamsal deneyimleri artmaktadır. Kişilik gelişiminde oldukça etkin bir dönem olan okul öncesi dönemde ciddiyetle ele alınması gereken "Değerler eğitimi” konusunu kazandırmada yaratıcı dramanın etkili bir yöntem olduğu söylenebilir. 


\section{Kaynakça}

Adıgüzel, Ö. (2012). Eğitimde yaratıcı drama. Ankara: Naturel Yayınevi.

Antepli S., (2016). Anne Baba Eğitimi Semineri Notları (yayımlanmamış). Ankara

Antepli S., (2014). Erken çocukluk eğitiminde tümel sanatlar, drama ve oyun etkinlikleri. Ankara: Kök Yayınc1lik.

Aslan, E. (2008). Drama temelli sosyal beceri eğitiminin 6 yaş çocuklarının sosyal ilişskiler ve iş birliği davranışlarına etkisi. Adnan Menderes Üniversitesi Sosyal Bilimler Enstitüsü Yüksek Lisans Tezi, Aydın.

Aydın, M.Z. (2010). Okulda çalı̧san herkesin görevi olarak değerler eğitimi. Ankara TOBB Ekonomi ve Teknoloji Üniversitesi Ceceli Eğitim Kurumları Değerler Eğitimi Buluşması. 10 Nisan 2010

Balat Uyanık, G. (2012). Okul öncesinde değerler eğitimi ve etkinlik örnekleri. Ankara: Pegem Akademi.

Balat Uyanık, G. ve Balaban Dağal, A. (2009). Okul öncesi dönemde değerler eğitimi etkinlikleri. Ankara: Kök Yayıncilik

Balat Uyanık G. (2005). Değerler eğitimi ve değerler eğitimi programları. Okul öncesi eğitimde güncel konular. Edt. Ayla Oktay, Özgül P. Unutkan. İstanbul: Morpa Kültür Yayınları, s. 197-208

Bolay, S.H. (2007). Değerlerimiz ve günlük hayat. Değerler Ĕ̆itimi Merkezi Dergisi, 1 (1), 12-19.

Dede, Y. (2007). Matematik Öğretiminde Değerlerin Yeri, AIBB̈̈ Eğitim Fakültesi Dergisi, Cilt 7, Sayı 1, s.1225.

Dilmaç, B. ve Ekşi, H. (2007). Değerler eğitiminde temel tartışmalar ve temel yaklaşımlar, İlk Öğretmen Ĕ̈itimci Dergisi, 14, 21-29.

Doğan, Nuri (1993). Illk ve orta dereceli okul ders kitapları ve sosyalleşme. Ankara: Bağlam Yayınları

Dökmen, Ü. (2005). Küçük şeyler (4.bs.). Sistem Yayıncılık 4. s.60

Erdem, A. R. (2007). An importand factor of culture of education faculties: values (a case study of the education faculty of pal1). Eurasion Journal of Educational Researc, 26: 95-108.

Güler,S. ve Yücelyiğit, S. (2014). Panpan ile etkinliker. Ankara: Animeto Hayalgücü Yapımcılık Yayıncılık, Yazılım Eğitim Hizmetleri Ltd. Şti.

Gönen, M. ve Uyar Dalkılıç, N. (2003). Çocuk eğitiminde drama yöntem ve uygulamalar. İstanbul: Epsilon Yayincilik,

Halstead, M. (1996). Values and values education in schools. In M.Taylor(Eds.) Values in Education in Values, (pp. 3-14). London: Falmer.

Hökelekli, H. ve Gündüz, T. (2007). Üstün yetenekli çocukların değer yönelimleri ve eğitimleri. Değerler ve Eğitimi Uluslararası Sempozyumu 26-28 Kasım 2004. Edt. Recep Kaymakcan, İstanbul: Dem Yayınları Ensar Neşriyat Tic.A.Ş, s. 371-394.

Kale, N. (2007). Nasıl bir değerler eğitimi. Değerler ve Eğitimi Uluslararası Sempozyumu, 26-28 Kasım 2004. Edt. Recep Kaymakcan, İstanbul: Dem Yayınları Ensar Neşriyat Tic.A.Ş. s.313-322.

Kan, Ç. (2010). Sosyal bilgiler dersi ve değerler eğitimi. Millî Eğitim ve Sosyal Bilimler Dergisi, Sayı 39 no:187, s.138-144.

Karasar, N. (2004). Bilimsel araştırma yöntemi (12.bs.). Ankara: Nobel yayınc1lık

Korkmaz Tosun, G. (2011). Okul öncesi çocukların ebeveynlerine yönelik değerler eğitiminin yaratıcı drama ile işlenmesi. Özel Doğaç Yaratıcı Drama Eğitmenliği/Liderliği Programı Bitirme Projesi. s.48

Köksal Akyol, A. (2012). Okul öncesi eğitimde drama ve öğretmenin rolü. Ankara Sağllk Bilimleri Dergisi, Cilt: 1 Sayı: 1 Sayfa: $105-116$

Köksal Akyol, A. (2003). Drama ve dramanın önemi. Türk Eğitim Bilimleri Dergisi, Cilt 1, Sayı 2 s. 4

Kula Kartal, S. ve Mor Dirlik, E. (2016). Geçerlik kavramının tarihsel gelişimi ve güvenirlikte en çok tercih edilen yöntem: Cronbach Alfa Katsayısı. Abant İzzet Baysal Üniversitesi Ĕgitim Fakültesi Dergisi, 16(4), 1865-1879. 
Matthews, B. (2001). The relationship between values and learning. International Education Journal, 2 (4). Educational Research Conference Special Issue. 223-232.

Özden, Y. (2005). Eğitimde yeni değerler; eğitimde dönüşüm. Ankara: Pegem-A Yayıncılık

San, İ. (1991). Yaratıcı drama- eğitsel boyutları. 1. Eğitim Kongresi, 25-27 Kasım 1991. Dokuz Eylül Üniversitesi Buca Eğitim Fakültesi İzmir, s.558-564.

Tahiroğlu, M. ve Yıldırım,T., Çetin,T. (2010). Değer eğitimi yöntemlerine uygun geliştirilen çevre eğitimi etkinliğinin, ilköğretim 7. sınıf öğrencilerinin çevreye ilişkin tutumlarına etkisi. Selçuk Üniversitesi Ahmet Keleşoğlu Ĕgitim Fakültesi Dergisi, Sayı 30, s. 231-248.

Taşdemir, M. (2009). İlköğretimde değerler eğitimi ve bu değerlerin alevî-bektaşî değerleri ile ilişkililiği, Türk Kültürü ve Hacı Bektaş Veli Araştırma Dergisi, Sayı 51 s.295-323.

Tezbaşaran, A. A. (1996). Likert tipi ölçek geliştirme klavuzu. Ankara: Türk Psikologlar Derneği Yayınları.

Ulutaş, A. (2011). Okul öncesi dönemde drama ve oyunun önemi. Adiyaman Üniversitesi Sosyal Bilimler Enstitüsü Dergisi, Sayı:6, s.232-242.

Yazar, A., Çelik, M. ve Kök, M. (2007). Okul Öncesi eğitimde yaratıcı dramanın çocuğun gelişim alanlarına etkisi. Atatürk Üniversitesi Kazım Karabekir Eğitim Fakültesi Dergisi, Sayı:16 s.15-21 


\section{Ekler}

\section{Ek 1: Okul Öncesi Dönemde Yaratıcı Drama Yoluyla Değerler Eğitimi Değerlendirme Anketi}

Aşağıda 24 adet madde bulunmaktadır. Lütfen bu maddeleri okuyarak, ilgili çocuğu en çok yansıttığını düşündüğünüz ifadeyi çarpı $(\mathrm{X})$ koyarak işaretleyiniz.

\begin{tabular}{|c|c|c|c|c|}
\hline & Maddeler & 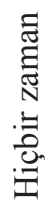 & 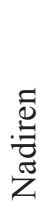 & 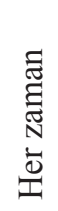 \\
\hline 1 & Yetişkinlere karşı saygılı ve nazik davranır & & & \\
\hline 2 & Selamlaşma, sıra olma, bağırmadan konuşma gibi toplumsal kuralları uygular. & & & \\
\hline 3 & Arkadaşlarına olan sevgisini davranışlarıyla yansıtır & & & \\
\hline 4 & Kendisine verilen görevleri yerine getirir. & & & \\
\hline 5 & Suyun, elektriğin vb. durumların boşa harcanmaması gibi konularda duyarlıdır. & & & \\
\hline 6 & Eşyalarına sahip çıkar, düzenli kullanır & & & \\
\hline 7 & Arkadaşlarıyla işbirliği yapar. & & & \\
\hline 8 & Yardıma ihtiyacı olan birisini gördüğünde ona yardım etmek için çaba gösterir. & & & \\
\hline 9 & Paylaşmayı sever. & & & \\
\hline 10 & Kişisel eşyalarını temiz ve düzenli kullanır. & & & \\
\hline 11 & Kişisel temizliğini aksatmadan ve zamanında yapar. & & & \\
\hline 12 & Çevresini temiz tutmaya özen gösterir. & & & \\
\hline 13 & Sıkıcı da olsa başladığı bir işi sonuna kadar devam ettirir. & & & \\
\hline 14 & İsteklerini erteleyebilir ve uygun zamanın gelmesini bekler. & & & \\
\hline 15 & Olumsuz tepkilerini bağırarak göstermez & & & \\
\hline 16 & Kendi çıkarına ters düşen durumlara rağmen doğruyu söyler & & & \\
\hline 17 & Sözünde durur. & & & \\
\hline 18 & $\begin{array}{l}\text { Emaneti korur (Ödünç aldığı bir şeyi zarar vermeden ve zamanı geldiğinde geri } \\
\text { verir) }\end{array}$ & & & \\
\hline 19 & Görev verildiği zaman kabul eder ve yerine getirir. & & & \\
\hline 20 & Başladığı işi zamanında tamamlar. & & & \\
\hline 21 & Araştırma yapmayı sever & & & \\
\hline 22 & Bir çalışmada öncü olduğunda, çevresindeki herkese adil davranır. & & & \\
\hline 23 & $\begin{array}{l}\text { İnsanlar arasında ayrım yapmaz ve eşit davranır (Engel durumu, ekonomik } \\
\text { durum vs). }\end{array}$ & & & \\
\hline 24 & Başkalarının da hakları olduğunu bilir ve bencil davranmaz. & & & \\
\hline
\end{tabular}




\section{Ek 2: Örnek Atölye Planı}

$\begin{array}{ll}\text { Konu } & : \text { İş birliği } \\ \text { Tarih } & : 16 / 04 / 2015 \\ \text { Süre } & : \text { 60' dakika } \\ \text { Teknikler } & : \text { Doğaçlama, rol oynama } \\ \text { Araçlar } & : \text { (Grup Şurup-Çocuk Şarkıları/ Üstünde altında), kağıttan yapılııs top, } \\ & \text { Örümcek Dodo Hikayesi (Yazan: Yıldız Kaya), Ek-4 İşbirliği çalışma } \\ & \text { yaprağı (Karınca resimleri Azman, Çelebioğlu ve Tunç (2010) etkinlik } \\ & \text { kitabından alıntıdır.) }\end{array}$

\section{Kazanımlar:}

1. Arkadaşlarıyla iş birliği yapar

2. Birlikte iş yapabilme ve görev paylaşımı yapmanın önemini fark eder

\section{Süreç}

\section{A-Hazırlık-Isınma}

\section{Etkinlik: Tünel/Köprü oyunu}

Lider çocukları iki guruba ayırır. Ayrılan çocuklar arka arkaya sıralanarak iki takım oluştururlar. İki grubun önündeki kişilere kağıttan yapılmış birer top verilir. Çocuklar toplarını bacak altından en arkaya doğru gönderirler. Toplar en arkadaki çocuklara ulaştığın da toplarla birlikte sıranın önüne gelirler. Tüm çocukların katılımıyla önce bitiren takım birinci olur. Daha sonra kağıt toplar baş üstünden elden ele verilerek aynı işlemler tekrarlanır. Her iki takımda oyunun sonunda alkışlanır (Antepli S. 2014-uyarlanmıştır)

\section{Ara değerlendirme:}

Çocuklardan minderlerine oturmaları istenir. Lider “Oynadığımız oyunu beğendiniz mi? Eğer ardı ardına sıra olmasaydık ve dağınık dursaydık öndeki top en arkaya daha zor gider miydi? Grubumuzun kazanması için iş birliği içinde yardımlaşarak çalışmak nasıl bir duygu?” sorularını sorar. Ardından iş birliği yapmak ne demek? Nasıl iş birliği yapılır? Evde ailemizle iş birliği yapıyor muyuz? Başka nerelerde iş birliği yapıyoruz? vb" sorularını sorduktan sonra çocuklara "Birlikte bir şeyler yapmak iş birliği yapmaktır. Örneğin sınıfımızı iş birliği yaparak toplayabiliriz. Evde annemizle iş birliği yaparak masayı hazırlayabiliriz" vb açıklamalarda bulunur.

\section{Çocukların paylaşımları:}

- $\quad$ Iş birliği yapmak birlikte çalışmaktır. Topu gönderirken arkadaşına yardımcı olmak demektir.

- $\quad$ Iş birliği içinde çalışmak güzel bir duygu.

- Annemle iş birliği yaparak evi topluyorum, yemek masasını hazırlıyorum.

- Annem kurabiye yaparken ona yardim ediyorum.

- Okulda oyun oynarken, yarışma yaparken iş birliği yapıyoruz. 


\section{B-Canlandirma}

\section{Etkinlik}

Çocuklarla çember şeklinde yere oturulur. Lider çocuklara "Örümcek Dodo" hikayesini anlatılır. Hikayenin konusu çocuklarla birlikte çözümlenir. Ardından çocuklara roller verilerek hikaye hep birlikte canlandırılır.

\section{Örümcek Dodo Hikavesi}

Her yeri yemyeşil otlar ve çiçeklerle dolu güzel bir kır bahçesi varmış. Burada karıncalar, uğur böcekleri, örümcekler, cırcır böcekleri ve daha bir sürü çeşit hayvan yaşarmış. Bu bahçede herkes birbirine yardım eder, el birliği ile tüm zorlukların üstesinden gelirlermiş. Onların bu güzel arkadaşlığını duymayan kalmamış. Komşu bahçelerden hayvanlar, onların bu hallerini görmeye gelirmiş. Bu çiftlikte her şey iyiymiş hoşmuş ama düzeni bozan birisi varmış. O da, kötü kalpli örümcek Dodo imiş. Örümcek Dodo, başkalarıyla oynamaz, onları korkuturmuş. Sadece korkutmakla kalmaz, birilerine yardım etmekten de nefret edermiş. Bu yüzden örümcek Dodo'nun hiç arkadaş1 yokmuş. Artık kimse onunla konuşmuyor, yanına bile gitmiyormuş. Ama o, halinden memnun görünüyormuş. "Amaaan, benden uzak dursunlar, daha iyi. Arkadaşa ihtiyacım yok zaten, diye kendini teselli ediyormuş.

Bir gece bütün hayvanlar uykuya dalmış. Karıncalar, uğur böcekleri, örümcekler, cırcır böcekleri, bahçede ne kadar hayvan varsa mışıl mışıl uyuyormuş. Tam o sırada, uyumayan bir kuş, örümcek Dodo'nun yuvasını bozmuş. Dodo ise yükseklerden sırt üstü yere düşmüş. Yüzüstü olmak için düzelmeye çalışmış ama bir türlü düzelememiş. Acı içinde bağırmaya başlamış. Sesini duyan diğer hayvanlar uyanmış ve hemen arkadaşlarını kurtarmak için çalışmaya başlamışlar. Ancak örümcek Dodo o kadar ağırmış ki kimse tek başına onu yüzüstü döndüremiyormuş. $\mathrm{Bu}$ yüzden iş birliği yapmaları gerekmiş. Karıncalar, tırtıllar, uğur böcekleri ve diğer bütün hayvanlar iş birliği içinde örümceğin bir yanından tutarak bütün güçleriyle arkadaşlarını düzeltmişler. Örümcek Dodo'nun sırtı çok ağrıdığı için karıncalar onu yuvasına taşımışlar. Diğer böcekler de ona yiyeceklerinden getirip iyileşmesi için çaba göstermişler. Olayın şokundan kurtulamayan örümcek, uzunca bir sure konuşamamış. Bu sırada, kendisine elbirliği ile yardım eden bütün hayvanların çabasını düşünüyormuş. Hayvanların nasıl hemen bir araya gelip yardıma koştuklarını, iyilik yapmak için sanki birbirleriyle yarış yaptıklarını hayretle izlemiş. Bu zamana kadar hiç yardım etmediği hayvan arkadaşları, onu yalnız bırakmadıkları için çok etkilenmiş. O günden sonra örümcek Dodo o kadar yardımsever, güler yüzlü ve arkadaş canlısı bir hayvan olmuş ki, bundan sonra herkes ona yardımsever örümcek Dodo demiş.

- Çocuklardan üçer kişilik karıncalar, uğur böcekleri, örümcekler ve cırcır böcekleri grupları oluşturuldu. Gönüllü bir çocuk örümcek Dodo, biri de kuş rolünü aldr. Lider hikayeyi anlatırken bu gruplar da kendi özelliklerine uygun sesler çıkartarak hareketlerini yaptilar. 


\section{C-Değerlendirme}

\section{Etkinlik:}

Çember olunarak yere oturulur. Lider çocuklara oynadığımız oyunlar hoşunuza gitti mi diye sorar. Ardından çocuklara şu soruları yöneltir: Ne hissettiniz? Zorda kalan birine yardım etmek nasıl bir duygu? Örümcek Dodo'ya yardım etmek için ne yapılacağına birlikte bir karar verip işbirliği içinde çalışmak nasıl bir duygu?

\section{Çocukların paylaşımları:}

- Evet, oyunlar çok hoşuma gitti.

- Zorda kalan birine yardım etmek çok güzel bir duygu.

- $\quad$ Örümcek Dodo'ya tek başına yardım edemedik. O yüzden hep birlikte çalışmak işe yaradl.

\section{Etkinlik:}

Çocuklardan masalarına geçmeleri istenir. Lider karıncaların olduğu çalışma yaprağını çocuklara göstererek şu soruları yöneltir: (EK-4 İş birliği çalışma yaprağı)

- Karıncalar birinci ve ikinci resimde ne yapıyor, anlatınız.

- Hangi resimde minder daha kolay taşınıyor? Yuvarlak içine alınız. Neden daha kolay taşındığını anlatınız (Azman, 2010-Değerler eğitimi davranış etkinlikleri 16. Fasikül 'den uyarlanmıştır.)

Azman, Çelebioğlu ve Tunç (2010)'un değerler eğitimi davranış etkinliklerinden uyarlanmıştır.

\section{Ek 3: İş̧birliği}

- Karıncalar birinci ve ikici resimde ne yapıyor, anlatınız.

- Hangi resimde minder daha kolay taşınıyor? Yuvarlak içine alınız.

- $\quad$ Neden daha kolay taşındığını anlatınız.
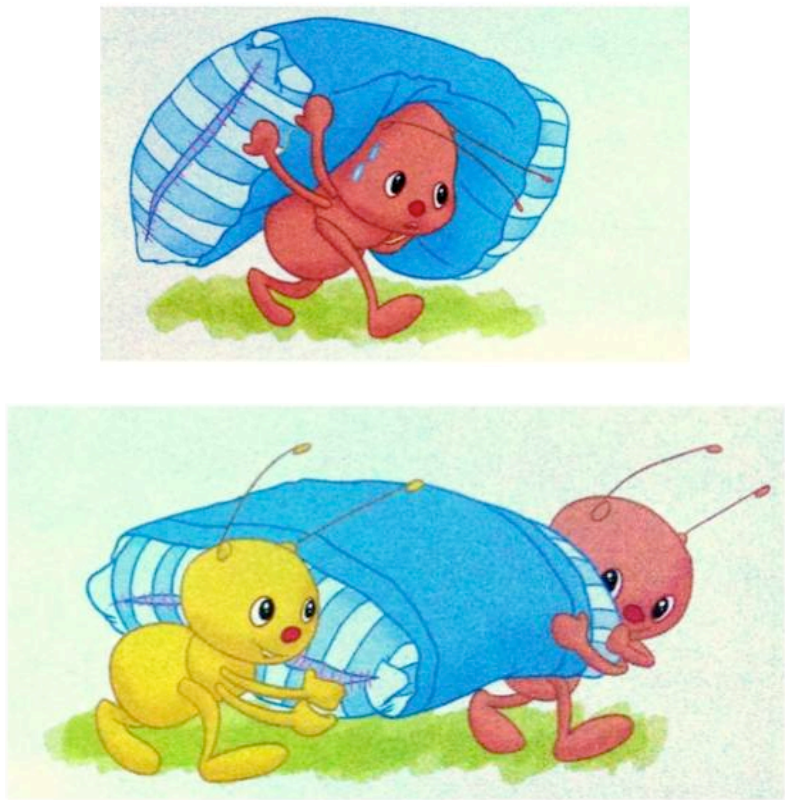

Azman, Çelebioğlu ve Tunç (2010)'un değerler eğitimi davranış etkinliklerinden uyarlanmıştır. 


\begin{tabular}{rr} 
çağdaş & Yaratıcı Drama Dergisi 2018, 13(2), 251-260 \\
drama & www.yader.org \\
\hline
\end{tabular}

\section{Sosyal Hizmet Eğitiminde Yaratıcı Dramanın Önemi \\ Ecem Naz Nazlıer ${ }^{1}$ \\ Gizem Akoğlu}

\begin{tabular}{|c|c|c|}
\hline \multicolumn{2}{|c|}{ Makale Bilgisi } & $\ddot{\mathbf{O} z}$ \\
\hline \multicolumn{2}{|c|}{ DOI: $10.21612 /$ yader.2018.018 } & Sosyal hizmet, insanın değerini göz önüne alan insan haklarl ve sosyal adalet ilkesi \\
\hline \multicolumn{2}{|c|}{ Makale Geçmişi } & ve meslektir. Sosyal hizmet eğitimi bilgi, beceri ve değer temeline dayanmaktadır. Yaşa \\
\hline Geliş tarihi & 21.03.2018 & ve ögren metoduna dayanan yaratıcı drama ise sosyal hizmet eğitiminde sosyal hizmet \\
\hline Kabul & 13.07.2018 & $\begin{array}{l}\text { beceri ve değerlerinin kazandıılmasında bir yöntem olarak kullanılabilmektedir. } \\
\text { Yaratıcılı̆̆ı ve iletişim becerilerinin gelişimini de hedefleyen yaratıcı drama, sosyal } \\
\text { hizmet uzmanlarının mesleki müdahalelerinde adeta onlara yol gösterici bir rehber }\end{array}$ \\
\hline \multicolumn{2}{|c|}{ Anahtar Sözcükler } & $\begin{array}{l}\text { niteliğindedir. Günümüzde yaratıcı drama bazı üniversitelerin sosyal hizmet lisans } \\
\text { bölümlerinde seçmeli ders olarak verilmektedir. Yaratıcı dramanın sosyal hizmet }\end{array}$ \\
\hline \multicolumn{2}{|c|}{ Sosyal hizmet eğitimi } & eğitiminde yaygınlaştırılmasının ögrencilerin hem kişisel hem de mesleki gelişimlerine \\
\hline \multicolumn{2}{|c|}{ Yaratıcı drama } & katkı sağlayacağı düşünülmektedir. \\
\hline
\end{tabular}

Sosyal hizmet beceri ve değer

temeli

\section{The Importance of Creative Drama in Social Work Education}

\begin{tabular}{lr}
\hline Article Info \\
\hline DOI: $10.21612 /$ yader.2018.018 \\
& \\
\hline Article History & \\
Received & 21.03 .2018 \\
Accepted & 13.07 .2018
\end{tabular}

Keywords

Social work eduation

Creative drama

Social work skills and values

\begin{abstract}
Social work is an applied discipline and profession that engages in micro, mezzo and macro level work within the framework of human rights and social justice principles that take human value into consideration. Social work education is based on knowledge, skills and value. The creative drama based on 'live and learn'method can be used as a method of gaining social work skills and values in social work education. The creative drama, which also targets the development of creativity and communication skills, is a guide in the professional interventions of social workers. Nowadays, creative drama is offered as an elective course in social work undergraduate departments of some universities. The spread of creative drama in social work education is thought to contribute to the personal and professional development of the students.
\end{abstract}




\section{Giriş}

Yaratıcı drama, gerçek dünya ve yaşantılardan yola çıkarak yeni bir kurgusal dünya oluşturmayı ve imgeleri algılama, anlama ve paylaşma eylemlerini içerir. Yaratıcı drama uygulamaları her yaş grubu insanla gerçekleştirilebilir. Araç, gereç ve metne dayalı olmadan kendiliğindenlik, şimdi ve burada ilkesi ve -mış gibi yapabilme özellikleriyle canlandırmanın gerçekleştirilmesi sağlanır. Yaratıcı drama katılımcı merkezlidir ve kişilerin gönüllülük esasına bağlı katılımını içerir.

Sosyal hizmet eğitimi içinde kullanılabilen farklı disiplinlerden biri olan yaratıcı drama, sosyal hizmet beceri ve değerlerinin sosyal hizmet öğrencilerine kazandırılmasında önemli bir role sahiptir. Bu bilgiden hareketle yaratıcı drama, sosyal hizmetin de bilgi, beceri ve değer temelinde yer alan mesleki uygulama ve duruşun öğrenciye aktarımında önemli bir araçtır.

$\mathrm{Bu}$ çalışma; ilgili alanyazındaki yaratıcı drama, sosyal hizmet mesleğinin beceri ve değer temeli ve yaratıcı drama ile sosyal hizmetin ortak çalışma alanları ve ilişkisi konularında yapılan araştırmalar, bilimsel makale, kitap ve bildiriler temel alınarak gerçekleştirilmiştir. İlgili literatürdeki veriler, doküman analizi yöntemi ile taranmıştır. Doküman analizi yapmanın amacı, araştırılması hedeflenen konuları içeren olgu ve olgular hakkında bilgi edinerek bu bilgilerin analiz etmektir. $\mathrm{Bu}$ çalışmanın amacı, yaratıcı dramanın sosyal hizmet eğitimindeki önemi konusunda farkındalık oluşturmaktır.

\section{Yaratıcı Drama Kavramı, Bileşenleri ve Aşamaları}

Yaratıcı drama, uygulamalı bir disiplin olarak tanımlanabilir. Yaratıcı dramanın kuramsal bilgi temelinin olması, kendine özgü tekniklerinin varlığ1 ve konu ile ilgili araştırmaların yapılması onun bilimsel bir alan olduğunun da göstergesidir (San, 2006; Akt., Başbuğ, 2006). Yaratıcı drama aynı zamanda sanatsal bir alandır. Bir başka deyişle özgünlüğün ve yaratıcılığın oluşturduğu bazı tekniklerin kullanıldığı sanatsal etkinliklerdir. Yaratıcı drama tiyatro yapmaktan farklıdır ancak tiyatro ve eğitim alanından beslenmektedir. Yazılı bir metne bağlı olmaksızın uygulanması ve sonuca değil sürece odaklanması onu tiyatrodan ayıran en önemli özelliklerdir.

Yaratıcı drama tanımlanırken drama sözcügünün önünde kullanılan yaratıcı sözcüğünün bilerek kullanıldığı ifade edilmektedir. Bu durum şu şekilde açıklanmaktadır: “Önceden yazılmış bir metin olmaksızın, katılımcıların kendi yaratıcı buluşları, özgün düşünceleri, öznel anıları ve bilgilerine dayanarak oluşturdukları eylem durumları, doğaçlama ve canlandırmalar yanını kapsar" (San, 1998; Akt., Adıgüzel, 2006, s. 21). Adıgüzel (2017) ise, yaratıcı dramayı şu şekilde ifade etmektedir:

Yaratıcı drama, bir grubu oluşturan üyelerin yaşam deneyimlerinden yola çıkarak bir amacın, düşüncenin doğaçlama, rol oynama vb. tekniklerden yararlanılarak canlandırılmasıdır. $\mathrm{Bu}$ canlandırma süreçleri, deneyimli bir lider/eğitmen eşliğinde yürütülürken kendiliğindenliğe (spontaniteye), şimdi ve burada ilkesine, -mış gibi yapmaya dayalıdır ve yaratıcı drama, oyunun özelliklerinden doğrudan yararlanır. (s. 41)

Yaratıcı drama, bireylerde estetik bir sanat anlayışı oluşturması sebebiyle eğitim alanı, yaşantının ortaya çıktığı süreci açıklaması ile disiplin ve bireylere bilgi, duygu ve devinimleri kazandırması sebepleriyle öğretim yöntemi olarak betimlenmektedir (Üstündağ, 1996; Akt., Ulubey ve Toraman, 2015, s. 197). Yaratıcı drama tanımlanırken literatürde kimi zaman farklı kavramların da kullanıldığı dikkat çekmektedir. Yaratıcı drama, eğitimde drama, eğitici drama ve eğitsel drama 
kavramları birbirinin yerine kullanılabilmekte ve aynı anlamı karşılamaktadır. Türkiye'de yaygın kullanım ise 'Eğitimde Yaratıcı Drama' şeklindedir (Adıgüzel, 2017, s. 48-50).

Yaratıcı drama kavram ve sürecini tam anlamıyla anlayabilmek için yaratıcı dramanın bileşenlerini ve amaçlarını bilmek gerekmektedir. Kendiliğindenlik, şimdi ve burada, -mış gibi yapmak kavramlarını içerisinde barındıran yaratıcı dramanın temel bileşenleri şu şekildedir: Lider/ eğitmen/öğretmen, konu-tema, teknikler (doğaçlama, rol oynama vb.), grup, yaşantı-tecrübe, yaratıcı dramaya uygun bir mekân (çalışma ortamı) ve canlandırma.

Yaratıcı drama etkinliklerinde liderin rolü oldukça önemlidir. Dramada lider, grup üyelerinin kendilerini rahatça ifade edebilecekleri ortamı yaratmalıdır. Grup üyelerinin dramatik oyunlarla, rahat davranışlar içerisinde duygularını ve düşüncelerini keşfetmelerine ve ifade etmelerine olanak sağlamalıdır. İyi bir lider, sorumluluk sahibi, anlayışlı ve iyi bir gözlem becerisine sahip olmalıdır (Ezer ve Ulukaya, 2017, s. 157). Atölye süreci öncesinde lider gerekli hazırlıkları yapmalıdır. Gerektiği noktalarda grup dinamiğinin sürekliliği için grup sürecine müdahalede bulunmalıdır. Lider, grup üyelerine gerekli yönlendirmeleri yapar ancak grup üyeleri bu yönlendirmeler dışında tamamen özgürdür.

Yaratıcı dramada konu, katılımcıların daha önce deneyimledikleri birçok durumu ifade edebilir. Üyelerin daha önce yaşadığı durumlar, hayalleri, bir gazete haberi, herhangi bir edebi metin, anı, fotoğraf vb. yaratıcı dramanın konusu olabilir. Konu çalışma öncesinde seçilmeli ve seçilen konu grubun özelliklerine uygun olmalıdır. Belirlenen amaç doğrultusunda seçilen konu çeşitli teknikler kullanılarak uygulanır. Yaygın olarak kullanılan teknikler rol oynama, doğaçlama, donuk imge, fragman tekniği şeklindedir. Yaratıcı dramada doğaçlama ve rol oynamanın yanı sıra "geriye dönüş, rol içinde yazma, öğretmenin role girmesi, görüşmeler, öğretici oyunlar vb.” gibi farklı teknikler de kullanılmaktadır (Adıgüzel 2006, s. 26).

Yaratıcı dramanın en önemli bileşenlerinden biri de gruptur. Yaş, cinsiyet, ilgi alanları ve grup üyelerinin ihtiyaçları drama içerisinde dikkate alınmalıdır. Gruplar oluşturulurken grup çalışmasına uygunluk ve bireylerin gönüllü katılımları oldukça önemlidir (Aral ve diğerleri, 2000; Akt., Ezer ve Ulukaya, 2017, s. 157). Grup üyeleri, grup yaşantısı ve gerçek yaşantıları arasında bağlantı kurarlar ve kendi yaşam deneyimlerini de yaptıkları canlandırmalarda sürece katarlar. San (1990) yaratıcı drama çalışmalarını, yaşam durumlarındaki dramatik anların grup içi etkileşim süreçleri içinde yaratılması, bir ayna tutulması olarak tanımlamaktadır (Akt., Adıgüzel, 2006, s. 22). Adıgüzel (2017, s. 78) drama gruplarında birlikte yaratma, üretme ve paylaşma süreçlerinin yaşandığını ifade etmektedir.

Yaratıcı dramanın bileşenlerinden bir diğeri de mekândır. Drama çalışmalarının uygulanabileceği mekânın seçiminde dikkat edilmesi gereken önemli noktalar; mekânın gürültüden uzak, güvenilir, drama çalışmalarının yapılmasına uygun, kişilerin rahatça hareket edebilecekleri şekilde düzenlenmesidir.

Yaratıcı drama çalışmaları temelde 3 aşamada yürütülür. Bu aşamalar hazırlık-1sınma, canlandırma ve değerlendirme olarak sınıflandırılır. Hazırlık-ısınma aşamasında amaca uygun aktiviteler kullanılarak grup canlandırma aşamasına hazırlanır. Bu aşamada duyu organlarının harekete geçirilmesi amacıyla çoğu zaman oyunlardan yararlanılır. Canlandırma aşaması ise grup üyelerine hedeflenen doğrultuda kazanımları edindirmeyi amaçlar. San (2001), yaratma ve hayal etme boyutlarının canlandırma içerisinde yer aldığını ifade etmektedir (Akt., Ezer ve Ulukaya, 2017, s. 156). Böylece grup üyelerinin hayal gücünün gelişmesi ve duruma ilişkin farkındalık kazanmaları 
sağlanabilir. Değerlendirme aşamasında ise lider grup üyelerine çeşitli sorular sorarak veyahut bazı etkinlikler düzenleyerek grup üyelerinden süreci değerlendirmelerini istemektedir. Bu sorular ve etkinlikler, katılımcıların önceden belirlenen kazanımına ulaşıp ulaşmadıklarını ölçer nitelikte olmalıdır. Lider değerlendirme aşamasında gruba verilmek istenen kazanımın verilip verilmediğini ölçer ve böylece sürecin başarılı geçip geçmediği, amacına ulaşıp ulaşmadığı belirlenmiş olur.

Yaratıcı drama, amaçları ve kazanımları olan bir alandır. Yaratıcı dramanın genel amacı, çocukların, ergenlerin ve gençlerin canlandırma aracılığıyla, bir bilinçlendirme ve kültürlenme süreci içerisinde, her alanda yaratıcı, kendini tanıyan, kendine yetebilen, çevresiyle iletişim kurabilen ve bunu geliştirebilen, ifade gücü artmış, imgesel düşünebilen, estetik kayg1, demokratik tutum ve davranışları gelişmiş bireyler yetiştirmek olarak tanımlanmaktadır (Adıgüzel, 2017, s. 63). Yaratıcı dramanın en önemli amaçlarından bir diğeri ise sosyal öğrenme, sosyalleşmedir (San, 2006; Akt., Başbuğ, 2006, s. 114).

Yaratıcı dramanın diğer alt amaç ve kazanımları; eleştirel düşünme, yaratıcılığı artırma, kendine güven ve karar verme becerileri, hayal gücü, duygu ve düşünceleri geliştirme, empati yapabilme, iletişim becerilerini artırma, farklı olay ve durumları deneyimleyebilme, problem çözme becerilerinin ve doğru davranışların kazandırılması, istenmeyen durumlarla nasıl baş edilebileceğinin öğrenilmesi şeklindedir (Üstündağ, 1988; Akt., Ezer ve Ulukaya, 2017, s. 153). Bu amaçlar ve kazanımlar ilerleyen bölümlerde sosyal hizmet mesleği açısından da incelenecektir.

\section{Sosyal Hizmet Disiplininin Beceri ve Değer Temeli}

Sosyal hizmet mesleğinin ve disiplininin bilgi, beceri ve değer temeli olmak üzere üç temel sac ayağı vardır. Mesleki çalışmalar; insan hakları, sosyal adalet, farklılıklara saygı temelinde yürütülmekte ve bu kavramlar sosyal hizmet eğitiminde önemli bir yere sahip olmaktadır.

Sosyal hizmet eğitiminde beceri gelişimi iki temel bileşeni içermektedir:

1. Var olan becerileri belli bir temele dayandırma, pekiştirme, güçlendirme ve keskinleştirme

2. Yeni becerileri fark etme, anlama ve geliştirme (Thompson, 2013, s. 126).

$\mathrm{Bu}$ bilgilerden hareketle müracaatçıyla sağliklı bir iletişim kurabilme ve karşı tarafin sorunlarını anlayabilmenin ilk koşulu kendini tanımadır. Sosyal hizmet eğitiminde becerilerin kazandırılması, kişinin kendilik bilincinin, empati becerisinin gelişmesine ve öz farkındalığının arttırılmasina yardımcı olur.

İyi bir sosyal hizmet müdahalesi için sosyal hizmet öğrencilerinin eğitimleri sırasında iletişim becerilerini geliştirmeleri gerekir. İletişim becerileri, duyguları ifade etme noktasında sözel ve sözel olmayan biçimleri içermektedir. Thompson (2013, s. 127) sosyal hizmet uzmanlarının olumlu bir etki için kendi beden dillerini kullanmalarının yanı sıra, sözsüz iletişimi de başarılı bir biçimde okuyabilmeleri gerektiğinden bahsetmektedir.

Sosyal hizmet mesleği ve disiplininin müdahale aşamasında yararlandığı diğer bir beceri analitik düşünme becerisidir. Analitik düşünme, yaratıcıllı̆̆ ve eleştirel düşünmeyi temel alır. Sosyal hizmet müdahalelerinde her bireyin biricikliğinden hareketle, bireylere farklı çözüm yolları bulunmalıdır. Bu nedenle sosyal hizmet uzmanlarının vakaları çözümlerken standartlaşmış, tek tip çözümler bulmak yerine yaratıcılık becerilerini kullanmaları gerekmektedir. 
Sosyal hizmet müdahale süreci; olaylar arasında neden sonuç ilişkisi kurarak bireylere sorun çözme becerilerinin kazandırılması ve bireylerin güçlendirilmesi süreci olarak düşünülebilir. Sosyal hizmet müdahalesi, müdahale süreci boyunca tarafsızlığın sürdürülmesi, müracaatçı ve sosyal hizmet uzmanı arasında güvenli ilişkinin geliştirilmesi, problemin anlaşılıp çözümlenmesi, neyin doğru neyin yanlış olduğunun süreç boyunca sorgulanması ve problemlerle baş edebilmek için stratejiler geliştirilmesini içerir.

Sosyal hizmetin diğer bir sacayağı olan değer temeli, geleneksel değerler ve özgürleştirici değerler olmak üzere ikiye ayrılmaktadır. Geleneksel ve özgürleştirici değerler birbirinden ayrı düşünülmemeli, aksine birbirinin tamamlayıcısı olarak değerlendirilmelidir. Özgürleştirici değerler 1960'l1 yıllardan itibaren ortaya çıkmış olup, radikal sosyal hizmetin gelişmesini sağlamış ve sosyo politik bağlamda da ayrımcılık karşıtı uygulamanın temellerini oluşturmuştur. Özgürleştirici değerler temelinde; güç, eşitsizlik, sosyal adalet gibi konular gündeme gelmiştir (Thompson, 2013, s. 170). Özgürleştirici değerler, bireyin sorun ve ihtiyaçlarının sadece birey özelinde değil, toplumdaki yapısal eşitsizliklerle de alakalı olabileceğini gündeme getirmiştir.

Sosyal hizmet eğitiminde geleneksel ve özgürleştirici değerlerin kazandırılması amaçlanmaktadır. Bu temel amaç doğrultusunda; kişilere saygı duyan, müracaatçıya kendi kaderini tayin hakkı tanıyan, sosyal adaleti ve eşitliği önemseyen, müracaatçıyı güçlendiren ve yargılayıcı olmayan tutum içindeki sosyal hizmet uzmanları alana daha büyük katkılar sağlayacaklardır.

\section{Sosyal Hizmet Eğitiminde Yaratıcı Drama}

Sosyal hizmet; birey, grup ve politika düzeyinde çalışmalar yapan, çalıştığ birey ya da grupların güçlendirilmesini, baş etme kapasiteleri ile kendi kendine yetebilirliklerinin arttırılmasını hedefleyen, değişim ve gelişim odaklı uygulamalı bir meslektir. Truell (2014) sosyal hizmeti şu şekilde tanımlamaktadır: "Sosyal hizmet, sosyal değişimi ve gelişimi, toplumsal bağlılığı ve insanları güçlendiren (ekonomik, politik, sosyal, eğitimsel, cinsiyet ya da ruhsal yönlerden, birey ve cemiyetleri geliştiren) ve özgürleştiren uygulama temelli meslek ve akademik disiplindir." (Artan, çev. t.y.)

Sosyal hizmet eğitimi, bu gelişim ve değişimi sağlaması açısından oldukça önemlidir. Sosyal hizmet eğitiminin temellerini bilgi, beceri ve değer temeli oluşturur. Bilgi temeli, dört y1llık lisans eğitimi boyunca kuramsal ve teorik bilgiler doğrultusunda sosyal hizmet öğrencilerine verilir. Kuramsal bilgiyi alan öğrenciler bu bilgileri beceri ve değer temeli eğitimi ile de birleştirerek alanda uygulamalarını yapar. Bu gerekli beceri ve değerlerin kazandırılmasında sosyal hizmet eğitimi içinde farklı disiplinlerden yararlanılabilir.

Yaratıcı drama ise bilişsel, duyuşsal ve devinişsel davranışları kazandırma konusunda önemli bir öğretim yöntemidir. Yaratıcı dramanın yaşanılan süreci betimleme, açıklama ve kontrol edebilme imkânlarıyla bireylerin gelişimine katkı sağladığı düşünülmektedir (Üstündağ, 1998, s. 30). Yaratıc1 drama, - katılımcıların yararı için oluşturulan dramatik tecrübeler - rol oynama, rol analizi ve iş birliği içerisinde çalışma gibi aktiviteler aracılığıyla kişilerin duygusal kontrolünü gerektiren yaratıcı görevler içerisinde sürece katılımları için kişilere firsat sağlamaktadır (Freeman, Sullivan ve Fulton, 2003, s. 131).

Yaratıcı drama çalışmalarının hem örgün öğretimde hem yaygın eğitimde kullanımı her geçen gün artmaktadır. Yaratıcı drama, eğitimde öğrencinin aktif katılımını destekleyerek bedenini 
ve duyu organlarını harekete geçirebilmesine katkı sağlar. Bu kimi zaman ders ortamında öğrenme ve öğretme sürecinde, kimi zaman ise bir kurs ortamında gerçekleştirilebilir. Böylece öğrenci, öğrenme sürecinde etkin konuma gelmektedir. Öğrenci kendi yaptığıyla öğrenirken bir yandan da duyu organlarını harekete geçirmekte, olay ya da durumları yaşayarak deneyimlemektedir (Üstündağ, 1988, s. 59; Akt., Üstündağ 1998, s. 29). Yaratıc1 drama, yaşa ve öğren (live and learn) metodunun temelini inşa eder (Ezer ve Ulukaya, 2017, s. 152). Yaratıcı dramanın, öğrencilerin diğer insanlarla olan ilişkilerinde, nasıl hareket edecekleri ve nasıl düşüneceklerini değiştirme noktasında onlara katkısı vardır (Akt., Önalan-Akfırat, 2006, s. 50). Yaratıcı drama süreci, öğrencilerin özgüvenlerini ve cesaretlerini arttırma noktasında da öğrenciye katkı sağlar. Ayrıca canlandırma sürecinde öğrencilerin yaşadıklarını hissederek öğrenmelerini sağlar. Böylece hem diğer bireylerin davranışlarını gözlemleyerek hem de kendi davranışlarının farkına vararak öğrencilerin gelişimleri desteklenir (Akt., Ulubey ve Toraman, 2015, s. 197).

Sosyal beceriler; bireyin diğer insanlarla olan ilişkilerinde öğrenme, soru sorma, kendi ihtiyaçlarını dile getirme ve diğer insanların istekleriyle ilgilenme, insanlarla etkili zaman geçirebilme, arkadaşlık kurma, kendi haklarını koruma ve diğer insanların haklarını ihlal etmeme gibi her bireyin sahip olması gereken becerilerdir (Dowd ve Teirney, 2005; Akt., Namdar ve Çamadan, 2016, s. 561). Metinnam (2012)'a göre yaratıcı drama uygulamaları grup halinde gerçekleştirilir ve pek çok kazanımın elde edilmesinde grup çalışması büyük ölçüde etkilidir (Akt., Namdar ve Çamadan, 2016, S. 560).

Sosyal hizmet uzmanlarının, çalıştığı gruplar genellikle dezavantajlı olarak da tanımlanabilecek, görece ihtiyaç ve sorunları olan insanlardır. Müracaatçı ve sosyal hizmet uzmanı arasındaki ilişkinin niteliği iyi bir iletişim kurulmasına bağlıdır. Yaratıcı drama, sosyal hizmetin de temel aldığ1 farklılıklara sayg1, ayrım yapmama, kendi kaderini tayin hakk1 gibi müracaatçı ile iletişimdeki önemli noktalara ilişkin değerlerin kazandırılmasında etkilidir. Bu değerlerin yanı sıra empati, kendini tanıma, farkındalık oluşturma, kendine güveni arttırma, sosyalleşme, problem çözme, yaratıcılık, duygusal ifade ve duyguların kontrolü, karar verme gibi beceriler de yaratıcı drama eğitimi ile pekiştirilebilir. Literatürde yaratıcı dramanın beceri gelişimine etkisi konulu çok sayıda çalışma bulunmaktadır. Literatür taraması sırasında incelenen çalışmaların sonuçları, yaratıcı drama eğitiminin bireylere iletişim becerileri noktasında katkı sağladığını ve atölyeler sonunda katılımcıların iletişim becerileri düzeylerinde anlamlı değişimler olduğunu göstermektedir (Yüksel Şahin, 1997; Akoğuz, 2002; Afacan ve Turan, 2012).

Sosyal hizmet alanında yaratıcı drama uygulaması ile ilgili çalışmaların oldukça sınırlı olduğu görülmektedir. Sosyal hizmet alanında yapılan birkaç çalışma şu şekildedir:

Altınova ve Çiftçi (2013)'nin sosyal hizmet öğrencileriyle yapmış olduğu yarı deneysel çalışmada, yaratıcı drama uygulamasının sosyal hizmet bölümünde öğrenim gören öğrencilerin kendilerini ifade etme becerileri üzerinde etkili olduğu sonucuna ulaşmıştır. Yaptıkları 12 haftalık yaratıcı drama uygulaması sonucunda öğrencilerin kendilerini tanıtırken cümle ve sözcük sayılarının arttığı, kendini ifade etme, kendine ait farkındalık oluşturma ve kendini tanıma düzeylerinin geliştiği bilgisine ulaşmışlardır. Çiftçi ve Altınova (2017) yaptıkları diğer bir çalışmada ise yaratıcı dramanın sosyal hizmet öğrencilerinin iletişim becerilerine etkilerini araştırmışlardır. 12 oturumluk uygulama sonucunda öğrencilerin iletişim beceri düzeylerinde anlamlı bir artış gözlemlenmiştir. 
Öngen, Özateş Gelmez ve Hatipoğlu Eren (2017) sosyal hizmet öğrencileriyle 8 hafta boyunca yaptıkları bir diğer çalışmada da öğrencilerin sosyal hizmetin değer temelini anlamalarına yönelik bir program uygulamışlardır. Çalışmada öğrencilerin kişisel değerlerini ve değerlendirme biçimlerini keşfetmelerini, sosyal hizmetin geleneksel ve özgürleştirici değerlerini öğrenmelerini, kişisel değerlerinin ve değerlendirme biçimlerinin mesleki uygulamaları üzerindeki olası etkilerini görmelerini amaçlamışlardır. Öğrencilerin değerlendirmeleri sonucunda; atölye çalışmasıyla hedeflenen kazanımlara ulaşıldığı, öğrencilerin sosyal hizmetin değer temeline ilişkin öğrenme süreçlerinin kolaylaştırılarak mesleki değerlerin daha kolay anlaşılmasının sağlandığı sonucuna ulaşı1mıştır.

Sosyal hizmet, odağı insan olan ve insanlarla sürekli etkileşim ve iletişim içinde olmayı gerektiren mesleki bir disiplindir. Bu bağlamda sosyal hizmet eğitiminde, sosyal hizmetin mesleki değerlerinin anlaşılması ve uygulamaya aktarılması noktasında yaratıcı dramanın yöntem ve tekniklerini kullanmak faydalı olmaktadır. Araştırmalardan hareketle sosyal hizmet eğitiminde uygulanan yaratıcı drama çalışmalarının öğrencilerin sosyal hizmetin beceri ve değer temelini yaşayarak ve öğrenerek deneyimlemelerine olanak sağladığı söylenebilir.

Yaratıcı drama sadece bir disiplin ve sanat olmanın ötesinde, sosyal hizmet uzmanları için aynı zamanda müracaatçı ile kurduğu iletişimde yararlanabileceği bir yöntemdir. Sosyal hizmet uzmanları hem kendilerini rahatça ifade etme noktasında, hem de müracaatçılarının ihtiyaç duydukları alana ilişkin olumlu bir baş etme mekanizması geliştirebilmesi ve bunu içselleştirebilmesi noktasında yaratıcı dramadan faydalanabilmektedir. Kendini tanımak, fark etmek ve o süreci deneyimlemek uzmanın hem kişisel gelişiminde hem de mesleki gelişiminde etkilidir.

Yaratıcı drama sosyal hizmet müracaatçılarının, ihtiyaçlarını ve kendilerini ifade etmelerinin sözsüz bir yoludur (York, t.y.; Akt., Jackson, 2015). Bazen bir şeyleri anlamak ya da anlatmak söz ile yetersiz kalabilmektedir. Hayal dünyası, doğaçlama ve kendiliğindenlik birtakım şeyleri ifade etmekte ve farkındalık oluşturmada etkilidir. Yaratıcı drama sözlü olabileceği gibi aynı zamanda sözsüz iletişimin de bir yoludur. Yaratıcı dramanın atölye aşamalarında kullanılan rol oynamadoğaçlama teknikleri katılımcıların başkası gibi düşünebilme ve başkasının yerine geçebilme becerilerini artıracağından sosyal hizmet uzmanlarının alanda uygulama yaparak müracaatçılar ile empati kurabilme beceresine yardımcı olmaktadır. Bu nedenle sosyal hizmet öğrencilerinin lisans eğitimleri sırasında aldıkları temel yaratıcı drama eğitimleri onların alanda daha etkili uygulamalar yapmalarına olanak vermektedir. Yaratıcı drama, öğrencilerin toplumsal konularda duyarlılık kazanmalarını ve bu konulara ilişkin farkındalık geliştirmelerini sağlar.

Müracaatçıların biricikliği, sorun ve ihtiyaçlarının farklılaşması nedeniyle her birine farklı müdahaleler gerektirmesi ve sosyal hizmetin insana değer veren bir meslek olmasından hareketle sosyal hizmet öğrencilerine eğitim verilirken yaratıcı dramadan ve yaratıcı drama uygulamaları ile geliştirilen yaratıcılıktan yararlanmak mesleki uygulamalarda oldukça yararlı olacaktır. Yaratıcı drama yöntemi ve tekniklerinin sosyal hizmet eğitimi alan öğrencilere öğretilmesi, öğrenciler mezun olup alana çıktıklarında (sosyal hizmet uzmanı olduklarında), onların problemleri daha iyi tanımlayabilmelerine, beceri ve değer temelinde daha uygun ve iyi müdahale yöntemleri geliştirebilmelerine katkı sağlayacaktır. 


\section{Sonuç}

Yaratıcı dramanın temel felsefesi ‘yaşa ve öğren' (live and learn) şeklindedir. Bireylerin bir bilgiyi yalnızca okuyarak öğrenmesindense yaşayarak, tartışarak, empati kurarak, grup dinamiği içinde öğrenmesi çok daha kalıcı olabilmektedir. Aksi takdirde, sosyal hizmet lisans eğitimi sırasında üst üste yığılan bilgi bir yerden sonra kalıcılığını yitirebilir. Sosyal hizmet mesleği, temelinde daima insanın değerli olduğu bilincini, insanlarla iletişim kurmayı ve insanlara dokunmayı barındırmaktadır. $\mathrm{Bu}$ nedenle her daim dinamik ve yaratıcı kalması oldukça önemlidir.

Yaratıcı drama eğitiminin sağladığı katkıların önemi yadsınamaz bir gerçektir. Bugün okul öncesinden başlanılarak her yaş grubunda verilmesi gereken yaratıcı drama eğitimi, sosyal hizmet eğitiminde de mutlaka yer almalıdır. Alana çıkacak uzman adaylarının, sosyal hizmet becerilerini geliştirmeleri ve sosyal hizmet değerlerini içselleştirmesi bakımından da yaratıcı drama eğitimi önemli bir yere sahiptir. Böylece yaratıcı drama eğitimi ile iletişim kurma, aktiflik ve yaratıcılık gibi beceriler doğal bir öğrenme ortamında pekiştirilmiş olur.

Yetkin bir sosyal hizmet uzmanı olabilmek için en önemli beceri, insanlarla ilişki kurmak ve onlara danışmanlık vermek olarak tanımlanmaktadır (Zastrow, 2013). Bu becerilerin geliştirilmesinde bir eğitim yöntemi olan yaratıcı drama oldukça önemlidir. Günümüzde sosyal bilimler alanındaki lisans bölümlerinde yaratıcı drama seçmeli ders olarak verilmektedir. Üniversitelerin bazı sosyal hizmet bölümlerinde yaratıcı drama dersi hiç yokken bazılarında ise seçmeli ders şeklindedir. Yaratıcı drama dersi seçmeli ders olarak 2008 yılından beri Hacettepe Üniversitesi Sosyal Hizmet Bölümü’nde verilmektedir. Yaratıcı drama diğer üniversitelerin sosyal hizmet bölümlerinde de bir ders olarak verilmeli ve ders sonunda beklenen ve istenen kazanımlar doğrultusunda hedefler konulmalıdır. Ders iki dönem boyunca birbirinin devamı şeklinde olmalı ve dersin ilk döneminde katılımcılar/öğrenciler ile kendilerini tanıma, drama geçmişi oluşturma (iletişim-etkileşim, uyumgüven çalışmaları), sosyal hizmet becerilerini fark etme ve kullanma, sosyal hizmet değerlerini anlama gibi amaçlarla grup çalışmaları yapılmalıdır. Böylece onlara yaratıcı drama sürecini deneyimleme firsatı da verilmelidir. İkinci döneminde ise yaratıcı drama tekniklerinin alanda nasıl kullanılacağına yönelik, katılımcıların/öğrencilerin daha aktif olduğu çalışmalar yapılmalıdır. Böylece hem sosyal hizmet becerileri kullanılarak pekiştirilmeli, hem de alanda bu becerilerin kullanımı ile ilgili somut örnekler sunulmalıdır.

İlgili alanyazında, yaratıcı drama ve sosyal hizmet ilişkili çalışmaların yok denecek kadar az olduğu fark edilmektedir. Hem öğrencilerde hem uzmanlarda bu konuya ilişkin farkındalığı arttırmak amacıyla yaratıcı dramanın sosyal hizmet eğitimindeki önemi ve yaratıcı dramadan nasıl faydalanılacağı konulu akademik çalışmaların arttırılması gerekmektedir. 


\section{Kaynakça}

Adıgüzel, Ö. (2006). Yaratıcı drama kavramı, bileşenleri ve aşamaları. Yaratıcı Drama Dergisi, 1(1), 17-29.

Adıgüzel, Ö. (2017). Eğitimde yaratıcı drama (10.bs). Ankara: PegemA Yayınları.

Afacan, Ö. ve Turan, F. (2012). Fen bilgisi öğretmen adaylarının iletişim becerilerine ilişkin algılarının belirlenmesinde yaratıcı drama yönteminin kullanılması. Sosyal Bilimler Enstitüsü Dergisi, 33(2), 211-237.

Akoğuz, M. (2002). Illetişim becerilerinin geliştirilmesinde yaratıcı dramanın etkisi. Yüksek lisans tezi, Ankara Üniversitesi Eğitim Bilimleri Enstitüsü, Ankara.

Altınova , H. H. ve Gökçeaslan Çiftci, E. (2013). Yaratıcı dramanın kendini tanıma düzeyine etkisi. Yaratıcı Drama Dergisi, 8(15), 28-47.

Başbuğ, S. (2006). Yaratıcı dramanın Türkiye'deki öncülerinden 'Prof.Dr.İnci San'ın yaratıcı drama anlayışı". Yaratıcı Drama Dergisi, 1(2), 111-121.

Ezer, F. ve Ulukaya, Ü. (2017). Teaching social studies with creative drama method. içinde W. J. Wu, E. Koçoğlu ve Ö. Akman, New Approaches in Social Studies Education I (ss. 151-163). ISRES Publishing.

Freeman, G., Sullivan, K. ve Fulton, R. (2003). Effects of creative drama on self-concept, social skills, and problem behavior. The Journal of Educational Research, 96, 131-138.

Gökçearslan Çiftçi, E. ve Altınova, H. H. (2017). Sosyal hizmet eğitiminde yaratıcı drama yöntemiyle iletişim becerisi geliştirme: ders uygulaması örneği. Elementary Education Online, 16(4), 1384-1394.

Jackson, K. (2015). Creative arts therapies in social work. Social Work Today, 15(3).

Jackson, N. ve Burgess, H. (2005). Creativity in social work and social work education. http://www.heacademy.ac.uk/creativity.htm adresinden edinilmiştir.

Namdar, A. O. ve Çamadan , F. (2016). Yaratıcı drama uygulamalarının öğretmen adaylarının sosyal becerilerine etkisi. GEFAD/GUJGEF, 557-575.

Önalan Akfırat, F. (2006). Sosyal yeterlilik, sosyal beceri ve yaratıcı drama. Yaratıcı Drama Dergisi, 1(1), 39-58.

Öngen, Ç., Özateş Gelmez, Ö. S. ve Hatipoğlu Eren, B. (2017). Yaratıcı dramanın sosyal hizmet eğitiminde kullanımı: sosyal hizmetin değer temeline ilişkin bir atölye çalışması. Uluslararası Sosyal Hizmet Kongresi 29-31 Mayls 2017 içinde (s. 376-377). Hacettepe Üniversitesi, Ankara.

Thompson, N. (2013). Kuram ve uygulamada sosyal hizmeti anlamak. (B. Hatipoğlu Eren ve Ö. Cankurtaran Öntaş, Çev.). Ankara: Dipnot Yayınları.

Truell, R. (n.d.). IFSW Sosyal Hizmet. (İ. Artan, Ed.). IFSW: http://ifsw.org/sosyal-hizmet-nedir/ adresinden edinilmiştir.

Ulubey, Ö. ve Toraman, Ç. (2015). Yaratıcı drama yönteminin akademik başarıya etkisi: bir meta-analiz çalışması. Mustafa Kemal Üniversitesi Sosyal Bilimler Enstitüsü Dergisi, 12(32), 195-220.

Üstündağ, T. (1998). Yaratıcı drama eğitim programının ögeleri. Eğitim ve Bilim Dergisi, 22(107), 28-35.

Yüksel Şahin, F. (1997). Grupla iletişim becerileri eğitiminin üniversite öğrencilerinin iletişim beceri düzeylerine etkisi. 12-19.

Zastrow, C. (2013). Sosyal hizmete giriş. (D. B. Çiftci, Ed.). Ankara: Nika Yayınevi. 



\section{Yaratıcı Drama Dergisine İlişkin Açıklamalar ve Yazım Kuralları}

\section{Yaratıcı Drama Dergisi’ne Yayımlanmak üzere gönderilen yazılar:}

1. Alana uygunluk açısından öncelikle editör tarafından incelenerek yayın kuruluna iletilir. Yayımlanmasına karar verilen yazılar, bilimsel açıdan değerlendirilmek üzere en az iki hakem tarafindan incelenir.

2. Hakem raporlarından birinin olumlu, diğerinin olumsuz olması durumunda, makale değerlendirilmek üzere üçüncü hakeme yönlendirilir. Hakem raporlarının olumlu olması durumunda yazı, yayım programına alınır.

3. Hakem raporlarına göre üzerinde değişiklik yapılması gereken yazılardaki tüm değişiklikleri yazarlar kendileri yaparlar. Son şekli verilen yazılar üzerinde yazarlarca bir değişiklik yapılmaz.

4. Hakem raporları gizlilik içerir. Yazarlar, hakem ve Yayın Kurulu'nun eleştiri, öneri ve düzeltmelerini dikkate almak zorundadırlar. Yazarlarla hakemler arasındaki iletişimi yalnızca Yayın Kurulu sağlar.

5. Yayım sırasında, ilk olarak yazının Yaratıcı Drama Dergisi'ne gönderiliş tarihi, sonra da hakemlerden alınan puanlar dikkate alınmaktadır.

6. Yaratıcı Drama Dergisi'nde yayımlanan yazıların sorumluluğu yazar/lar/a aittir. Yayımlanan yazılar konusunda Çağdaş Drama Derneği ve Yaratıcı Drama Dergisi sorumluluk kabul etmez.

7. Yayın Kurulu, gönderilen yazıları yayımlayıp yayımlamamakta serbesttir. Gönderilen yazılar yayımlansın veya yayımlanmasın yazara iade edilmez.

8. Yayımlanmış yazıların yayın hakları Yaratııı Drama Dergisi’ne aittir.

9. Yaratıcı Drama Dergisi’nin ve yazar/ların adları kaynak gösterilerek alıntı yapılabilir.

10. Yazılar, yazar soyadına göre alfabetik sırada yayımlanır. İki ya da daha fazla yazarlı makalelerde yazılar, ilk yazarın soyadı esas alınarak sıralanıp yayımlanır.

11. Bir sayıda, aynı yazarın tek isim olduğu tek makale yayımlanabilir.

\section{Dergiye gönderilecek yazılar;}

a) Kağıt boyutları: A4 boyutunda kağıda, üst, alt, sağ ve soldan $2,5 \mathrm{~cm}$ boşluk bırak1larak (16x24,7 cm'lik alana), 1,5 satır aralıklı, 11 punto ve Times New Roman yazı karakteri kullanılarak yazılmalıdır.

b) Tablo, resim, şekil, grafik vb.: Derginin sayfa boyutlarının dışına taşmaması amacıyla 10x17 cm'lik alanı aşmamalıdır. Tablo, resim, şekil, grafik ve benzerlerinde daha küçük punto ve bir satır aralığı kullanılabilir. Tablo, şekil ve ekler, metin içerisinde, başlıklarıyla yer almalıdır. Tablo ve şekillerin öncesine ve sonrasına $12 \mathrm{nk}$ boşluk verilir, tablo başlıkları ve metin 10 punto, tablo ve numarası koyu yazılmalidir.

c) Makale Başlığı; 14 punto, bağlaçlar hariç her sözcüğün baş harfi büyük olarak yazılmalıdır. Başlık 17 sözcüğü geçmemelidir. Proje kapsamında hazırlanan, sözlü bildiri, doktora ya da yüksek lisans tezinden üretilmiş veya destek almış çalışmalar başlığa * şeklinde dipnot ile verilir. Başlıktan sonra bir boşluk ile dipnot verilmelidir. 
d) Yazar Ad/lar/ı; 12 punto, ortalı, yazar adı soyadı sadece baş harfleri büyük olarak dipnotta rakamla $1-2$ şeklinde verilmelidir.

e) Özet Başı̆̆ğ; 10 punto ve koyu yazılmalıdır.

f) Türkçe/İngilizce Özet Metni; 10 punto, iki tarafa yaslı şekilde, 150-250 sözcük arası yazılmalıdır. Paragraf var ise paragraflar arası $6 \mathrm{nk}$ boşluk verilmelidir.

g) Anahtar Sözcükler Başıı̆̆ı; 10 punto, koyu yazılmalıdır.

h) Anahtar Sözcükkler; 10 punto büyüklüğünde, en fazla 5 anahtar sözcük yazılmalıdır.

i) Ana Başlıklar; (Giriş, Yöntem, Tartışma ve benzeri temel başlıklar)10 punto, koyu ve ortalı, altından ve üstünden $6 \mathrm{nk}$ boşluk ile yazılmalıdır.

j) Alt Başlıklar; paragraf başı 1,25 $\mathrm{cm}$ içerden, 11 punto, koyu, italik, iki yana yaslı yazilmalidir.

k) Paragraflar; paragraf başları 1,25 cm içeriden, 11 punto, iki yana yaslı, paragraflar arası $6 \mathrm{nk}$ boşluk bırakılarak yazılmalıdır.

13. Gönderilen yazılar; özetler ve kaynakça dahil 20 sayfayı geçmemelidir.

14. Gönderilen yazılar aşağıdaki bölümleri içermelidir:

a) Başık sayfası: Yazar/lar/ın tüm ve açık adları, çalıştıkları kurumlar, makale üst başlığının Türkçe ve İngilizce isimleri ile Türkçe ve İngilizce özetleri içermelidir.

b) Ana Metin: Ampirik çalışmalar; giriş, yöntem, bulgular, tartışma ve sonuç bölümlerini içermelidir.

c) Yöntem: Bu kısım; örneklem, veri toplama aracı ve işlem, verilerin analizi alt k1sımlarını içermek zorundadır. Derleme türü çalışmalar problemi ortaya koymalı, ilgili alanyazını etkili bir biçimde analiz etmeli, alanyazındaki eksiklikler, boşluklar ve çelişkilerin üzerinde durmalı ve çözümler için öneriler içermelidir. Diğer çalışmaların başlıklandırılmasında farklılıklar olabilir, ancak yazıların okuyucuyu sıkmayacak akıcılık ve bilimsellikte olması gerekmektedir.

d) Kaynakça: Hem metin içinde hem de kaynakçada Amerikan Psikologlar Birliği (APA) tarafindan yayınlanan Puplication Manual of American Psychological Association (5. Bask1 2001) adlı kitapta belirtilen yazım kurallarına uyulmalıdır.

15. Yayın Kurulu ile ilgili yazışmalar için e-posta adresi mutlaka yazılmalıdır.

16. Türkçe makalelerde metin içinde referans verirken mümkün olduğu kadar ana kaynağa ulaşılmalıdır.

17. Yazılar, Yaratıcı Drama Dergisi’nin e-posta adresine (cdddergi@gmail.com) gönderilmelidir.

18. Yayımlanan yazıların içeriğinde olabilecek çarpıtmalardan, alıntı yapan yazar ya da yazarlar sorumludur.

19. Yaratıcı Drama Eğitmenlik/Liderlik kurslarında bitirme projesi olarak yapılan çalışmalar danışman adı ikinci isim olmak üzere, danışman adıyla birlikte yayımlanır.

20. Başka bir yerde yayımlanan yazılar (yayımlanmış seminer ve kongre bildirileri, vb.), Yayın Kurulu'nun onayıla Yaratıcı Drama Dergisi'nde yayımlanabilir. 


\section{Yaratıcı Drama Dergisi Kaynakça Yazım Örnekleri}

Dergimizde Amerikan Psikologlar Derneği (Publication of Manual of American Psychological Association-APA) tarafından yayınlanan yazım ilkeleri benimsenmiştir.

\section{Kitap}

Adıgüzel, Ö. (2013). Eğitimde yaratıcı drama (4.bs.). Ankara: PegemA Yayınları.

Gönderme: (Adıgüzel, 2013, s.234)

\section{İki Yazarlı Kitap}

Kitson, N. ve Spiby, I. (1997). Drama 7-11: Developing primary teaching skills (3rd ed.). New York:

Routledge Publication.

\section{Kitap İçinde Bölüm}

Güven, İ. (2008). Okul öncesi drama etkinliklerinde ilkeler. A. Öztürk (Yay. Haz.). Çocukta Yaratıcılık ve Drama içinde (ss. 199-212). Eskişehir: Anadolu Üniversitesi Yayınları.

Gönderme: (Güven, 2008, s.207)

\section{Çeviri Kitap}

Lewis, B. (2000). Modern Türkiye'nin doğuşu (M. Kıratlı, Çev.). Ankara: Türk Tarih Kurumu. Gönderme: (Lewis, 2000, s. 12)

\section{Editörlü Kitap}

Kilpatrick, J. (2004). (Ed.). A Research companion to principles and xtandards for school mathematics,

Reston, VA: NCTM, Inc. Educational Research Information Center (ERIC)

\section{Tek Yazarlı Makale}

San, İ. (1990). Eğitimde yaratıcı drama. Ankara Üniversitesi Eğitim Bilimleri Fakültesi Dergisi, 23(2), 573-582.

Gönderme: (San, 1990, s. 574)

\section{İki yazarlı makale}

Özdemir, P. ve Akkuş-Çıkla, O. (2005). Use of creative drama in science and mathematics by preservice elementary teachers. Hacettepe Üniversitesi Eğitim Fakültesi Dergisi, 27, 157-166.

\section{Elektronik Makale}

Karakelle, S. (2012). Üstbilişsel farkındalık, zeka, problem çözme algısı ve düşünme ihtiyacı arasındaki bağlantılar. Eğitim ve Bilim, 37(164), 237-250. 3 Aralık 2014 tarihinde http:// egitimvebilim.ted.org.tr/index.php/EB/article/view/779/376 adresinden erişildi.

Gönderme: (Karakelle, 2012, s. 240) 


\section{Tez}

Aykaç, M. (2011). Türkçe ögretiminde çocuk edebiyatı metinleriyle kurgulanan yaratıcı drama etkinliklerinin anlatma becerilerine etkisi. Yayınlanmamış doktora tezi, Ankara Üniversitesi Eğitim Bilimleri Enstitüsü Hacettepe, Ankara.

Gönderme: (Aykaç, 2011, s.67)

\section{Bildiri}

Akfirat Önalan, F. ve Tunç, A. (2003). Grup rehberlik etkinliklerinde yaratıcı dramanın yeri: Yaparak yaşayarak öğrenme. VII. Ulusal Psikolojik Danışma ve Rehberlik Kongresi 09-11 Temmuz 2003 içinde (s. 91-93). İnönü Üniversitesi, Malatya: PegemA Yayınc1lık, 139-140.

Gönderme: (Akfirat Önalan ve Tunç, 2003, s. 92)

\section{Web Sayfaları}

UNESCO. (2013). World Heritage list. UNESCO web sitesinden 21 Aralık 2013 tarihinde erişildi: http://whc.unesco.org/en/list

Gönderme: (UNESCO, 2013)

\section{Şekiller}

Her şeklin numarayı içeren bir başlığı olmalı ve bu başlık şeklin altına yazılmalıdır.

\section{Tablolar}

Tablo numarası ve adı tablonun üstünde yer almalıdır. Tablo adı, tablo numarasının altından başlayarak, sola dayalı bir şekilde, baş harfleri büyük ve italik olarak yazılmalıdır. Tablo sadece yatay çizgiler kullanılarak oluşturulmalıdır. Aşağıda bir tablo örneği verilmiştir.

Tablo 1. Yaratıcı Drama Temelli Hazırlanan Fen ve Matematik Ders Planlarının Sinıf Düzeyine ve Ünitelere Göre Dă̆ılımı

\begin{tabular}{cccccc}
\hline & 1. sınıf & 2. sınıf & 3. sınıf & 4. sinıf & 5. sınıf \\
\hline \multirow{2}{*}{ Yaşayan canlılar } & Fen ders planları & & & & \\
Elektrik & - & - & - & 5 & 1 \\
& - & - & 1 & 3 & - \\
Sayılar & Matematik ders planları & & & & \\
Geometri & - & - & 1 & - & 1 \\
Ölçme & 1 & - & 3 & 1 & 1 \\
Veri analizi & - & 2 & 1 & - & - \\
\hline
\end{tabular}




\section{Submission Guidelines for Creative Drama Journal}

\section{Articles sent to Creative Drama Journal for Publication:}

1. Firstly, articles are delivered to editorial board by examining by the editor in terms of appropriateness to the field. The articles, which are decided to be published, are examined by at least two referees to be evaluated from a scientific point.

2. In the event that one of the referee reports is positive and the other one is negative, article is directed to the third referee to be evaluated. In case of positive referee reports, article is included in the publication program.

3. Authors make all changes in the articles on which changes are required according to referee reports on their own. No change is made on the final versions of the articles by the authors.

4. Referee reports include privacy. Authors have to take the critics, suggestions and corrections of the referee and Editorial Board into consideration. Communication between authors and referees is only ensured by the Editorial Board.

5. During publication, firstly the sending date of the article to Creative Drama Journal is considered and then the scores obtained from the referees are considered.

6. Responsibility of the articles published in Creative Drama Journal pertains to the author/s/ of the articles. Contemporary Drama Association and Creative Drama Journal do not accept responsibility related to the published articles.

7. The Editorial Board is free to publish and not to publish the submitted articles. Submitted articles are not returned to the author whether they are published or not.

8. The rights of publication of the published articles pertain to Creative Drama Journal.

9. Quotation can be made by giving reference of Creative Drama Journal and the name/s of the author/s.

10. Articles are published in alphabetical order by authors' surnames. In articles with two or more authors, articles are sorted and published based on the first author's surname.

11. In an issue, one article can be published in which the same author is the only name.

12. Articles to be sent to the journal;

I) Paper sizes: It should be written on A4 sized paper with 1.5 line spacing and without end of line hyphenation by leaving $2,5 \mathrm{~cm}$ space from top, bottom and left (on an area of $16 \times 24,7 \mathrm{~cm}$ ) and by using 11 point size and Times New Roman typeface.

m) Tables, pictures, figures, graphics, etc..: They should not exceed the area of 10x17 $\mathrm{cm}$ in order not to extend beyond the journal page sizes. Smaller font size and one line space can be used on tables, pictures, figures, graphics and so on. Tables, figures and appendices should be included in the text with their titles. $12 \mathrm{pt}$ space is left before and after tables and figures, table titles and text should be 10 point size, table and its number should be written in bold.

n) Title of the Article; It should be written as 14 point size, and the first letter of every word should be written as capital letter except for the conjunctions. Title should not exceed 17 words. Studies, which are produced from verbal notification and doctoral 
or postgraduate thesis or which received support, are indicated by footnote in the title as *. Footnote should be given by a space after title.

o) Name/s of the Author/s; They should be given in footnote in figures as 1-2 along with the title, institution he/she works and e-mail address as 12 point size, centered, and only the first letters of author name and surname should be capital letter.

p) Title of Abstract; It should be written as 10 point size and in bold.

q) Turkish / English Text Abstract; It should be written as 10 point size, italic, justified alignment and between $90-120$ words. If there is a paragraph, $6 \mathrm{pt}$ space should be given between paragraphs.

r) Title of the Keywords; It should be written as 10 point size and in bold.

s) Keywords; Maximum 5 keywords should be written as 10 point size.

t) Main Titles; (Introduction, Method, Discussion and similar basic titles) It should be written as 11 point size, bold and centered, in the way that only the first letters are capital letter, and with $6 \mathrm{pt}$ space from top and bottom.

u) Subtitles; paragraph indentation should be written as $1.25 \mathrm{~cm}$ inside, 11 point size, bold, italic and justified alignment.

v) Paragraphs; Paragraph indentations should be written as $1.25 \mathrm{~cm}$ inside, 11 point size, justified alignment by leaving 6pt space between paragraphs.

13. Submitted articles should not exceed 20 pages, including abstracts and references.

14. Submitted articles should include the following sections:

e) Title page: It should include the full name/s and explicit name/s of the author/s, the institutions they work, Turkish and English names of top article title and its Turkish and English abstracts.

f) Main Text: Empirical studies should include the sections of introduction, method, findings, discussion and the results.

g) Method: This section must include the sub-sections of sampling, data collection and processing and analysis of data. Review article-type studies should reveal the problem, should analyze the relevant literature effectively, should put emphasis on shortcomings, gaps and contradictions in the literature and should include suggestions for solutions. There may be differences in giving title of other studies, however, articles should be fluent and scientific that will not make the readers bored.

h) References: Spelling rules specified in the book called Publication Manual of American Psychological Association (5th edition 2001) published by American Psychological Association (APA) should be obeyed both in the text and references.

15. E-mail address must be written for correspondences related to the Editorial Board.

16. While giving reference in the texts in Turkish articles, main source should be attained as far as possible.

17. Articles should be sent to Creative Drama Journal's e-mail address (cdddergi@gmail. com). 
18. Author or authors who cite/s are responsible for the distortions that may be in the content of the published articles.

19. Studies carried out as dissertation in Creative Drama Instructor/Leadership courses are published with the name of advisor including the advisor name and second name.

20. The articles published in somewhere else (published seminar and conference proceedings, etc.) can be published in Creative Drama Journal with the approval of the Editorial Board.

\section{Citation Format and Style Guide for Creative Drama Journal}

Publication of Manual of American Psychological Association-APA is adopted by our journal for formatting and style.

\section{JOURNALS}

\section{One Author}

San, İ. (1998). The development of drama in education in Turkey, Research in Drama Education, 3, 1, 96.

\section{Two Authors}

Özdemir, P. ve Akkuş-Çıkla, O. (2005). Use of creative drama in science and mathematics by preservice elementary teachers. Hacettepe Üniversitesi Ĕ̆itim Fakültesi Dergisi, 27, 157-166.

\section{BOOKS AND CHAPTER IN BOOKS}

\section{One Author}

Üstündağ, T. (2004) Yaratıcı drama öğretmenimin günlüğü (6. bask1). Ankara: PegemA Yayınc1lık.

\section{Two Authors}

Kitson, N. ve Spiby, I. (1997). Drama 7-11: Developing primary teaching skills (3rd ed.). New York: Routledge Publication.

\section{Editor instead of author}

Hemingway, E. (1999). The killers. In J. Updike \& K. Kenison (Eds.), The best American short stories of the century (pp.78-80). Boston, MA: Houghton Mifflin.

Kilpatrick, J. (2004). (Ed.). A Research companion to principles and standards for school mathematics, Reston, VA: NCTM, Inc. Educational Research Information Center (ERIC)

\section{Thesis or dissertation}

Duatepe, A. (2004). The effects of drama based instruction on seventh grade students' geometry achievement, Van Hiele geometric thinking levels, attitude toward mathematics and geometry. Unpublished $\mathrm{PhD}$ dissertation, Ankara: METU. 


\section{Published Presentation Papers}

Adıgüzel, H. Ö. (2002). Eğitim bilimlerinde ve sanat eğitiminde yöntem, disiplin ve sanatsal boyutlarılla yaratıcı drama. 11. Eğitim Bilimleri Kongresi, Yakın Doğu Üniversitesi, KKTC, 23-26 Ekim.

\section{Online Sources}

\section{Online Journal}

Andersen, C. (2004, June). Learning in "As-If" worlds: Cognition in drama in education. . 43, 4, Retrieved November 3, 2004, Academic Index.

\section{Citing in the text}

\section{One Author}

Linn's (1999) study...

As it is indicated (Way, 1973) in a new research,...

\section{Two or more authors}

If the paper is published by two authors, then full names of both authors must be written through all the text. If the paper is published by three or more authors, then in the first citation full names of authors must be written, but then for other citations, only the first authors' first name must be written and other authors must be written as "others".

\section{Figures}

All the figures must have a title that include also a number. And this title must be under the figure.

\section{Tables}

The name and the number of table must be at the top of the table. Name of the table must begin after the number of table. And it must be aligned-left, written by initial capital letters and italic. The table must be constituted by only horizontal lines. You can find an example below.

Tablo 1. Yaratıcı Drama Temelli Hazırlanan Fen ve Matematik Ders Planlarının Sinıf Düzeyine ve Ünitelere Göre Dağılımı

\begin{tabular}{cccccc}
\hline & 1. sınıf & 2. sınıf & 3. sınıf & 4. sınıf & 5. sınıf \\
\hline \multirow{2}{*}{ Yaşayan canlılar } & Fen ders planları & & & & \\
Elektrik & - & - & - & 5 & 1 \\
& - & - & 1 & 3 & - \\
Sayılar & Matematik ders planları & & & & \\
Geometri & - & - & 1 & - & 1 \\
Ölçme & 1 & - & 3 & 1 & 1 \\
Veri analizi & - & 2 & 1 & - & - \\
\hline
\end{tabular}


